\title{
A Sequential Acyl Thiol-Ene and Thiolactonization Approach for the Synthesis of $\delta$-Thiolactones
}

\author{
Ruairí O. Mc Court ${ }^{[a]}$ and Eoin M. Scanlan ${ }^{[a]}$
}

[a]: Trinity Biomedical Sciences Institute (TBSI), Trinity College Dublin, The University of Dublin, Dublin 2, Ireland

\section{E-mail: scanlae@tcd.ie}

\section{Contents}

1. Instrumental and General Considerations....................................................................2

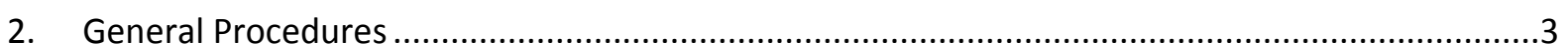

3. Preparation of Unsaturated Esters .............................................................................

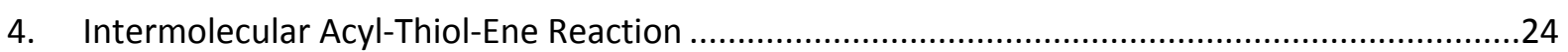

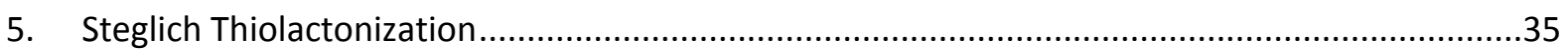

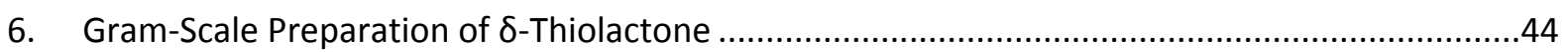

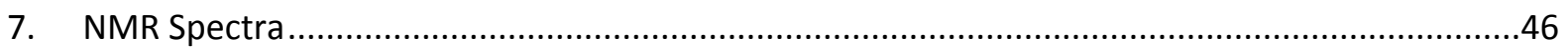
A) NMR Spectra of $\mathrm{y}$-Unsaturated Esters ..................................................................46

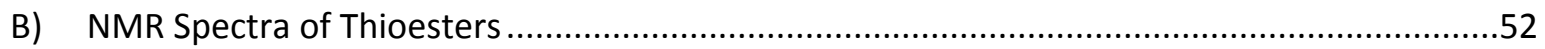

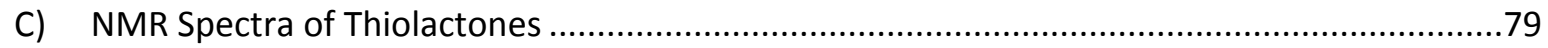

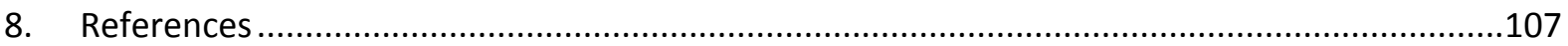




\section{Instrumental and General Considerations}

Unless otherwise stated; all commercial chemicals were obtained from Sigma-Aldrich, Fluka, Fluorochem, Alfa-Aesar, or Fischer Scientific, without further purification. Deuterated solvents for NMR were purchased from Apollo. Dry solvents were distilled under argon and dried over $4 \AA$ molecular sieves prior to use. Solvents for synthesis purposes were used at GPR grade. A Bruker Advance 400 spectrometer, ${ }^{1} \mathrm{H}(400.13 \mathrm{MHz})$ and ${ }^{13} \mathrm{C}(100.6 \mathrm{MHz})$ and a Bruker Ultrashield $600,{ }^{1} \mathrm{H}$ $(600.13 \mathrm{MHz})$ and ${ }^{13} \mathrm{C}(150.6 \mathrm{MHz})$, were employed for NMR spectra. Resonances $\delta$, from the centre point, are in ppm units downfield from an internal reference. ${ }^{1}$ NMR data was processed using TopSpin software. Infrared spectra (IR) were recorded on a Perkin Elmer spectrometer. High-resolution mass spectrometry (HRMS) analysis was performed with a Q-Tof Premier Waters Maldi-quadrupole timeof-flight (Q-Tof) mass spectrometer equipped with a with Z-spray electrospray ionisation (ESI), electron ionisation (EI), atmospheric -pressure chemical ionization, and matrix assisted laser desorption ionisation (MALDI) sources. Low-resolution mass spectrometry (LRMS) analysis was performed with an Advion compact mass spectrometer (CMS) equipped with a with Z-spray electrospray ionisation (ESI) source. Silica gel Florisil (200 mesh; Aldrich) was used for column chromatography. Analytical thin-layer chromatography (TLC) was performed using Merck 60 F254 silica gel (pre-coated, $0.2 \mathrm{~mm}$ thick, $20 \times 20 \mathrm{~cm})$ and visualised by UV light $(254 \mathrm{~nm})$, or molybdenum staining. All UV reactions were carried out in a Luzchem photoreactor, LZC-EDU $(110 \mathrm{~V} / 60 \mathrm{~Hz})$ containing $10 \mathrm{UV}$ lamps irradiating at $350 \mathrm{~nm}$ at $25{ }^{\circ} \mathrm{C}$. All compounds prepared via general procedures were done with the amount and equivalents reported, unless otherwise stated. Thioesters and thiolactones degraded over extended periods of time, despite storage at $-20^{\circ} \mathrm{C}$, and as a result HRMS data could not be obtained for all samples. In these cases, LRMS data has been provided. Thus, it is recommended that thioesters and thiolactones be used immediately after preparation. 


\section{General Procedures}

General Procedure A: Johnson-Claisen rearrangement:

To a stirred solution of allyl alcohol (1.0 equiv.) in orthoester(2.1 equiv.) was added $\mathrm{PhOH}$ ( 0.1 equiv.) and the mixture was heated at $140{ }^{\circ} \mathrm{C}$ for $12-18 \mathrm{~h}$. After this time, the apparatus was rearranged for distillation at $165^{\circ} \mathrm{C}$. After distilling for $1 \mathrm{~h}$, the remaining crude oil was cooled to rt. Purification was achieved by column chromatography on silica gel.

\section{General Procedure B: Intermolecular Acyl Thiol-Ene reaction:}

To a solution of alkene (1.0 equiv.), 2,2-dimethoxy-2-phenyl-acetophenone (DPAP) (0.1 equiv.) and 4methoxyacetophenone (MAP) (0.1 equiv.) in degassed EtOAc $(5 \mathrm{~mL} / \mathrm{mmol})$ was added HSAc (3.0 equiv.) and the reaction mixture was irradiated in the $\mathrm{UV}$ oven for $1 \mathrm{~h}$ at $25^{\circ} \mathrm{C}$. The solvent was removed in vacuo and the crude a product was purified by column chromatography on silica gel.

\section{General Procedure C: Ester/Thioester Hydrolysis \& Steglich thiolactonization:}

To the thioester (0.4-1.0 mmol, 1.0 equiv.) was added $1 \mathrm{M} \mathrm{NaOH}$ in $10 \% \mathrm{H}_{2} \mathrm{O} / \mathrm{MeOH}(10 \mathrm{~mL})$ and the mixture was stirred for $45 \mathrm{~min}$ at $90{ }^{\circ} \mathrm{C}$. The mixture was cooled to rt, diluted with an aqueous $1 \mathrm{M}$ $\mathrm{NaOH}$ solution, and poured into a separating funnel. The aqueous phase was extracted twice with $\mathrm{CH}_{2} \mathrm{Cl}_{2}$, and the organic phases were discarded. The aqueous phase was acidified with aqueous $4 \mathrm{M}$ $\mathrm{HCl}$ solution and extracted five times with $\mathrm{CH}_{2} \mathrm{Cl}_{2}$. The combined organic layers were dried over $\mathrm{MgSO}_{4}$, filtered and the solvent removed in vacuo to yield the crude 5-mercaptopentanoic acid, without further purification. No exhaustive characterisation of these species were attempted due to the propensity of these 5-mercaptopentanoic acid to form disulfides. The 5-mercaptopentanoic acid was dried under vacuum, placed under an atmosphere of argon, then dissolved in anhydrous $\mathrm{CH}_{2} \mathrm{Cl}_{2}(7.5$ $\mathrm{mL} / \mathrm{mmol}$ ) and cooled to $0{ }^{\circ} \mathrm{C}$. $N$-(3-Dimethylaminopropyl)- $N$-ethylcarbodiimide hydrochloride $(\mathrm{EDC} \cdot \mathrm{HCl})(2.0$ equiv.) and DMAP (1.2 equiv.) were added. After 30 mins, the reaction was warmed to $\mathrm{rt}$ and stirred for 8-14 $\mathrm{h}$. The solvent was removed in vacuo and the crude product was purified by column chromatography on silica gel. 


\section{Preparation of Unsaturated Esters}

1c was prepared according to the following sequence:

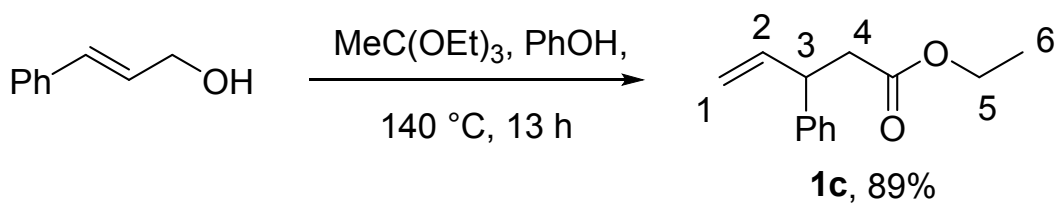

\section{Ethyl 3-phenylpent-4-enoate (1c)}

General procedure A to yield the title compound $(3.411 \mathrm{~g}, 16.7 \mathrm{mmol}, 88 \%)$ as a colourless oil from cinnamyl alcohol $(2.55 \mathrm{~g}, 19.0 \mathrm{mmol})$ and triethyl orthoacetate. Purification was achieved by column chromatography on silica gel using 4\% EtOAc/Hexane (v/v). $\boldsymbol{\delta}_{\mathbf{H}}\left(400 \mathrm{MHz}, \mathrm{CDCl}_{3}\right): 7.34-7.18(\mathrm{~m}, 5 \mathrm{H}$, Ar-H), 6.04-5.93 (m, 1H, H-2), 5.11-5.04 (m, 2H, H-1), 4.07 (q, $J_{5-6}=7.2$ Hz, 2H, H-5), 3.87 (app-q, 1H, H-3), 2.80-2.65 (m, 2H, H-4) 1.17 (t, $\left.J_{6-5}=7.2 \mathrm{~Hz}, 2 \mathrm{H}, \mathrm{H}-6\right)$. LRMS: (ESI $\left.{ }^{+}\right) \mathrm{m} / z$ calcd for $\mathrm{C}_{13} \mathrm{H}_{16} \mathrm{O}_{2} \mathrm{Na}\left([\mathrm{M}+\mathrm{Na}]^{+}\right): 227.1$; found: 227.1 . The spectral data were in accordance with those reported in the literature. ${ }^{2}$

1d was prepared according to the following sequence:

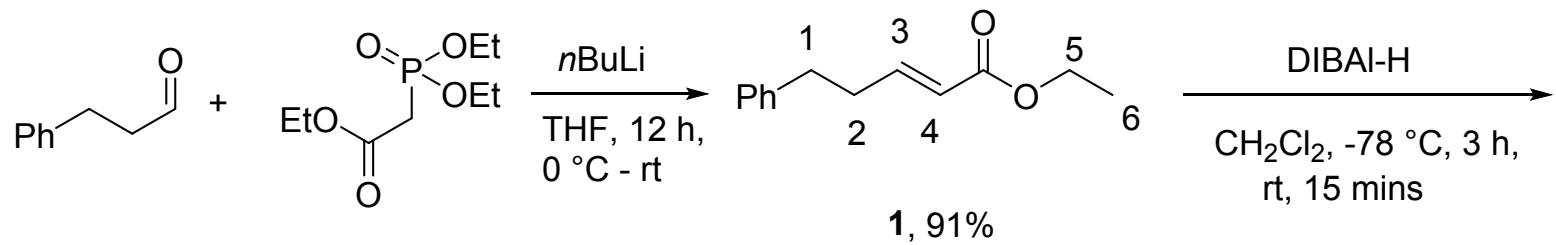<smiles>OC/C=C/CCc1ccccc1</smiles>

2, $87 \%$

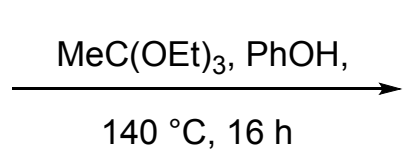

$140^{\circ} \mathrm{C}, 16 \mathrm{~h}$

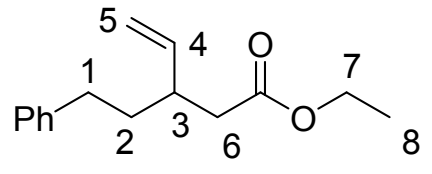

$1 d, 92 \%$

\section{Ethyl (E)-5-phenylpent-2-enoate (1)}

To triethyl phosphonoacetate $(2.4 \mathrm{~mL}, 12.0 \mathrm{mmol}, 1.2$ equiv.) in anhydrous THF (20 mL) under an atmosphere of argon at $0{ }^{\circ} \mathrm{C}$ was added $2 \mathrm{M} n$ BuLi solution in hexane $(6.5 \mathrm{~mL}, 13.0 \mathrm{mmol}, 1.3$ equiv.) and the mixture was stirred for $30 \mathrm{~min}$. Hydrocinnamaldehyde (1.3 mL, $10 \mathrm{mmol}, 1.0$ equiv.) in anhydrous THF $(5 \mathrm{~mL})$ was then added in, and after 10 mins the reaction mixture was allowed to warm to rt, and was stirred for a further $12 \mathrm{~h}$. The reaction was diluted $\mathrm{CH}_{2} \mathrm{Cl}_{2}(200 \mathrm{~mL})$ and quenched with $2 \mathrm{M}$ aqueous $\mathrm{HCl}(40 \mathrm{~mL})$. After phase separation, the aqueous phase was extracted further with $\mathrm{CH}_{2} \mathrm{Cl}_{2}$ $(2 \times 50 \mathrm{~mL})$. The combined organic layers were then washed with brine $(80 \mathrm{~mL})$, dried over $\mathrm{MgSO}_{4}$, filtered and the solvent removed in vacuo to yield the title compound as a fragrent colourless oil (1.858 g, 9.11 mmol, 91\%) without further purification being required. $\boldsymbol{\delta}_{\mathbf{H}}\left(400 \mathrm{MHz}, \mathrm{CDCl}_{3}\right): 7.31-7.23(\mathrm{~m}$ 
,2H, Ar-H), 7.21-7.14 (m,3H, Ar-H), $6.99\left(\mathrm{dt}, J_{3-4}=15.9 \mathrm{~Hz}, J_{3-2}=6.9 \mathrm{~Hz}, 1 \mathrm{H}, \mathrm{H}-3\right), 5.83$ (d, $J_{4-3}=$ $15.9 \mathrm{~Hz}, 1 \mathrm{H}, \mathrm{H}-4), 4.17$ (q, $\left.J_{5-6}=7.2 \mathrm{~Hz}, 2 \mathrm{H}, \mathrm{H}-5\right), 2.76$ (t, $\left.J_{l-2}=7.6 \mathrm{~Hz}, 2 \mathrm{H}, \mathrm{H}-1\right), 2.51$ (app-q, $2 \mathrm{H}$, $\mathrm{H}-2), 1.27$ (t, $\left.J_{6-35}=7.2 \mathrm{~Hz}, 3 \mathrm{H}, \mathrm{H}-6\right)$. LRMS: $\left(\mathrm{ESI}^{+}\right) \mathrm{m} / z$ calcd for $\mathrm{C}_{13} \mathrm{H}_{17} \mathrm{O}_{2}\left([\mathrm{M}+\mathrm{H}]^{+}\right): 205.1$; found: 205.2. The spectral data were in accordance with those reported in the literature. ${ }^{3}$

\section{(E)-5-Phenylpent-2-en-1-ol (2)}

To a solution of 1 (1.05 g, $5.15 \mathrm{mmol}, 1.0$ equiv.) in anhydrous $\mathrm{CH}_{2} \mathrm{Cl}_{2}(20 \mathrm{~mL})$ under an atmosphere of argon at $-78^{\circ} \mathrm{C}$ was added $1 \mathrm{M}$ DIBAl- $\mathrm{H}$ in $\mathrm{CH}_{2} \mathrm{Cl}_{2}(11.3 \mathrm{~mL}, 11.3 \mathrm{mmol} 2.2$ equiv.), and the reaction was stirred at this temperature for $3 \mathrm{~h}$. The reaction was then warmed to $\mathrm{rt}$ and $\mathrm{H}_{2} \mathrm{O}(2 \mathrm{~mL})$, then aqueous $1 \mathrm{M} \mathrm{NaOH}$ solution $(15 \mathrm{~mL})$, followed again by $\mathrm{H}_{2} \mathrm{O}(5 \mathrm{~mL})$, were added, with 5 minutes between each addition, maintaining vigorous stirring. The mixture was then poured into a separating funnel, and after phase separation, the aqueous phase was extracted with $\mathrm{CH}_{2} \mathrm{Cl}_{2}(2 \times 25 \mathrm{~mL})$. The combined organic layers were then washed with brine, dried over $\mathrm{MgSO}_{4}$, filtered through a plug of silica gel, and the solvent removed in vacuo to yield the title compound as a colourless oil ( $725 \mathrm{mg}, 4.48 \mathrm{mmol}, 87 \%)$ without the requirement for further purification. $\boldsymbol{\delta}_{\mathbf{H}}\left(400 \mathrm{MHz}, \mathrm{CDCl}_{3}\right): 7.30-7.23(\mathrm{~m}, 2 \mathrm{H}, \mathrm{Ar}-\mathrm{H}), 7.20$ $7.14(\mathrm{~m}, 3 \mathrm{H}, \mathrm{Ar}-\mathrm{H}), 5.77-5.61(\mathrm{~m}, 2 \mathrm{H}, \mathrm{H}-3, \mathrm{H}-4), 4.07$ (d, $\left.J_{5-4}=5.4 \mathrm{~Hz}, 2 \mathrm{H}, \mathrm{H}-5\right), 2.69$ (t, $J_{1-2}=7.6$ $\mathrm{Hz}, 2 \mathrm{H}, \mathrm{H}-1), 2.36$ (app-q, 2H, H-2). LRMS: $\left(\mathrm{ESI}^{+}\right) \mathrm{m} / z$ calcd for $\mathrm{C}_{11} \mathrm{H}_{14} \mathrm{ONa}\left([\mathrm{M}+\mathrm{Na}]^{+}\right): 185.1$; found: 185.1 . The spectral data were in accordance with those reported in the literature. ${ }^{4}$

\section{Ethyl 3-phenethylpent-4-enoate (1d)}

General procedure A to yield the title compound (624 mg, $2.689 \mathrm{mmol}, 92 \%)$ as a colourless oil from 2 (472 $\mathrm{mg}, 2.91 \mathrm{mmol}$ ) and triethyl orthoacetate. Purification was achieved by column chromatography on silica gel using 3.5\% EtOAc/Hexane (v/v). $\boldsymbol{\delta}_{\mathbf{H}}\left(400 \mathrm{MHz}, \mathrm{CDCl}_{3}\right): 7.30-7.23(\mathrm{~m}, 2 \mathrm{H}, \mathrm{Ar}-\mathrm{H}), 7.20$ 7.14 (m, 3H, Ar-H), 5.72-5.61 (m, 1H, H-4), 5.10-5.04 (m, 2H, H-5), 4.10 (q, $J_{7-8}=7.1 \mathrm{~Hz}, 2 \mathrm{H}, \mathrm{H}-7$ ), 2.76-2.62 (m, 1H, H-3), 2.61-2.48 (m, 2H, H-1), 2.44-2.26 (m, 2H, H-6), 1.79-1.68 (m, 1H, H-2), 1.66-1.55 (m, 1H, H-2'), 1.22 (t, $\left.J_{8-7}=7.1 \mathrm{~Hz}, 2 \mathrm{H}, \mathrm{H}-8\right)$. LRMS: $\left(\mathrm{ESI}^{+}\right) \mathrm{m} / \mathrm{z}$ calcd for $\mathrm{C}_{15} \mathrm{H}_{20} \mathrm{O}_{2} \mathrm{Na}$ $\left([\mathrm{M}+\mathrm{Na}]^{+}\right)$: 255.1; found: 255.1 . The spectral data were in accordance with those reported in the literature. ${ }^{5}$

1e was prepared according to the following sequence: 

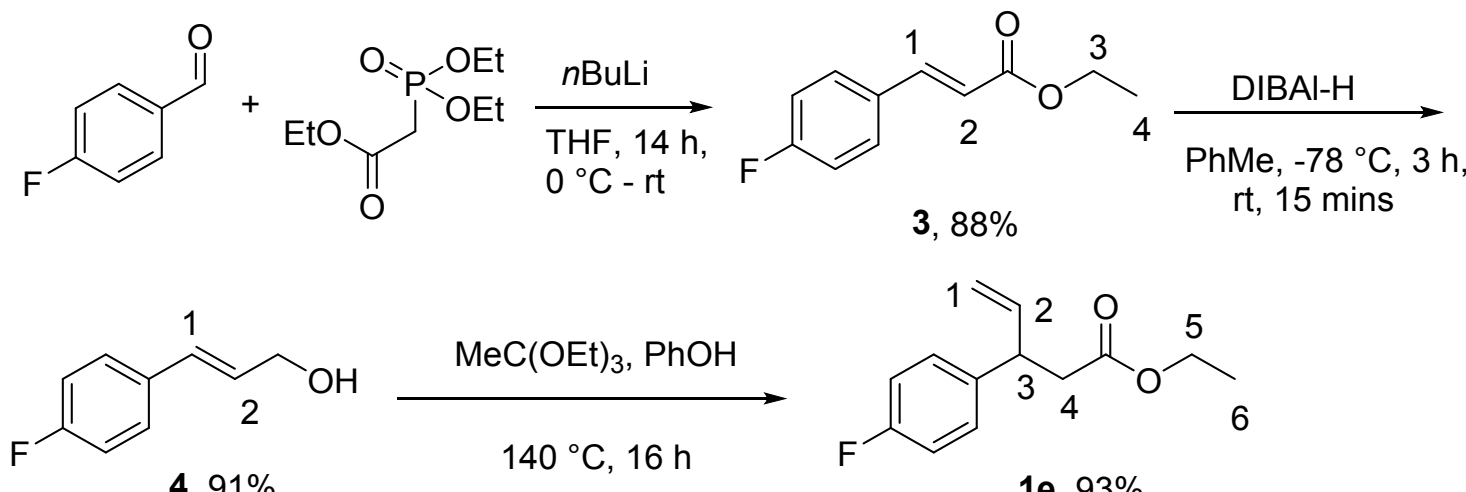

1 e, $93 \%$

\section{Ethyl (E)-3-(4-fluorophenyl)acrylate (3)}

To triethyl phosphonoacetate ( $3.0 \mathrm{~mL}, 15 \mathrm{mmol}, 1.25$ equiv.) in anhydrous THF $(50 \mathrm{~mL})$ under an atmosphere of argon at $0{ }^{\circ} \mathrm{C}$ was added $2.5 \mathrm{M} n \mathrm{BuLi}(7 \mathrm{~mL}, 17.5 \mathrm{mmol}, 1.5$ equiv.) and the mixture was stirred for $30 \mathrm{~min}$. 4-Fluorobenzaldehyde ( $1.3 \mathrm{~mL}, 12 \mathrm{mmol}, 1.0$ equiv.) was then added, and after 10 mins the reaction mixture was allowed to warm to rt, and was stirred for a further $14 \mathrm{~h}$. The reaction was diluted with $\mathrm{CH}_{2} \mathrm{Cl}_{2}(250 \mathrm{~mL})$ and quenched with $2 \mathrm{M}$ aqueous $\mathrm{HCl}(40 \mathrm{~mL})$. After phase separation, the aqueous phase was extracted further with $\mathrm{CH}_{2} \mathrm{Cl}_{2}(2 \times 50 \mathrm{~mL})$. The combined organic layers were then washed with brine, dried over $\mathrm{MgSO}_{4}$, filtered and the solvent removed in vacuo. Purification was achieved by column chromatography on silica gel using $3.0 \rightarrow 7.0 \%$ EtOAc/Hexane $(\mathrm{v} / \mathrm{v})$ to afford the title compound as yellow wax $(2.05 \mathrm{~g}, 10.6 \mathrm{mmol}, 88 \%) . \boldsymbol{\delta}_{\mathbf{H}}\left(400 \mathrm{MHz}, \mathrm{CDCl}_{3}\right): 7.65$ (d, $\left.J_{1-2}=16.0 \mathrm{~Hz}, 1 \mathrm{H}, \mathrm{H}-1\right), 7.54-7.48(\mathrm{~m}, 2 \mathrm{H}, \mathrm{Ar}-\mathrm{H}), 7.11-7.04$ (m, 2H, Ar-H), 6.36 (d, $J_{2-1}=16.0$ Hz, 1H, H-2), 4.27 (q, $J_{3-4}=7.2 \mathrm{~Hz}, 2 \mathrm{H}, \mathrm{H}-3$ ), 1.33 (t, $J_{4-3}=7.2 \mathrm{~Hz}, 3 \mathrm{H}, \mathrm{H}-4$ ). LRMS: (ESI') $\mathrm{m} / \mathrm{z}$ calcd for $\mathrm{C}_{11} \mathrm{H}_{8} \mathrm{OF}\left(\left[\mathrm{M}-\mathrm{H}_{2} \mathrm{O}-\mathrm{H}\right]^{-}\right)$: 175.1 ; found: 175.1. The spectral data were in accordance with those reported in the literature. ${ }^{6}$

\section{(E)-3-(4-Fluorophenyl)prop-2-en-1-ol (4)}

To a solution of 3 (970 mg, $5 \mathrm{mmol}, 1.0$ equiv.) in anhydrous $\mathrm{PhMe}(30 \mathrm{~mL})$ under an atmosphere of argon at $-78{ }^{\circ} \mathrm{C}$ was added $1 \mathrm{M}$ DIBAl-H in PhMe (12.5 mL, $12.5 \mathrm{mmol} 2.5$ equiv.), and the reaction was stirred at this temperature for $3 \mathrm{~h}$. The reaction was then warmed to $\mathrm{rt}$ and $\mathrm{H}_{2} \mathrm{O}(2 \mathrm{~mL})$, then aqueous $1 \mathrm{M} \mathrm{NaOH}$ solution $(15 \mathrm{~mL})$, followed again by $\mathrm{H}_{2} \mathrm{O}(5 \mathrm{~mL})$, were added, with 5 minutes between each addition, maintaining vigorous stirring. The mixture was then poured into a separating funnel, and after phase separation, the aqueous phase was extracted with PhMe $(2 \times 25 \mathrm{~mL})$. The combined organic layers were then washed with brine, dried over $\mathrm{MgSO}_{4}$, filtered through a plug of silica gel, and the solvent removed in vacuo to yield the title compound as a colourless oil (692 mg, $4.55 \mathrm{mmol}, 91 \%)$ without the requirement for further purification. $\boldsymbol{\delta}_{\mathbf{H}}\left(400 \mathrm{MHz}, \mathrm{CDCl}_{3}\right)$ : 7.38-7.32 (m, 2H, Ar-H), 7.04$6.98(\mathrm{~m}, 2 \mathrm{H}, \mathrm{Ar}-\mathrm{H}), 6.59\left(\mathrm{~d}, J_{1-2}=15.9 \mathrm{~Hz}, 1 \mathrm{H}, \mathrm{H}-1\right), 6.29\left(\mathrm{dt}, J_{2-1}=15.9 \mathrm{~Hz}, J_{2-3}=5.8 \mathrm{~Hz} 1 \mathrm{H}, \mathrm{H}-2\right)$, 
4.34-4.29 (m, 2H, H-3), $1.42\left(\mathrm{t}, J_{\mathrm{OH}-3}=1.8 \mathrm{~Hz}, 1 \mathrm{H}, \mathrm{OH}\right)$. LRMS: (ESI-) $m / z$ calcd for $\mathrm{C}_{9} \mathrm{H}_{8} \mathrm{OF}$ ([M$\left.\mathrm{H}^{-}\right)$: 151.1 ; found: 151.1 . The spectral data were in accordance with those reported in the literature. ${ }^{7}$

\section{Ethyl 3-(4-fluorophenyl)pent-4-enoate (1e)}

General procedure A to yield the title compound (619 mg, $2.79 \mathrm{mmol}, 93 \%$ ) as a colourless oil from 4 $(581 \mathrm{mg}, 3.0 \mathrm{mmol})$ and triethyl orthoacetate. Purification was achieved by column chromatography on silica gel using 6\% EtOAc/Hexane (v/v). $\boldsymbol{\delta}_{\mathbf{H}}\left(400 \mathrm{MHz}, \mathrm{CDCl}_{3}\right)$ : 7.20-7.15 (m, 2H, Ar-H), 7.02-6.96 (m, 2H, Ar-H), 6.00-5.90 (m, 1H, H-2), 5.10-5.02 (m, 2H, H-1), 4.07 (q, $\left.J_{5-6}=7.2 \mathrm{~Hz}, 2 \mathrm{H}, \mathrm{H}-5\right), 3.86$ (app-q, 1H, H-3), 2.78-2.61 (m, 2H, H-4), 1.17 (t, $\left.J_{6-5}=7.2 \mathrm{~Hz}, 2 \mathrm{H}, \mathrm{H}-6\right)$. LRMS: (ESI) $\mathrm{m} / z$ calcd for $\mathrm{C}_{13} \mathrm{H}_{13} \mathrm{O}_{2} \mathrm{~F}$ ([M+Na-2H]-): 243.1; found: 243.3. The spectral data were in accordance with those reported in the literature. ${ }^{8}$

1f was prepared according to the following sequence:<smiles>O=C(O)/C=C/c1ccc(Cl)cc1</smiles><smiles>C=CC(C)(CC(=O)OCC)c1ccc(Cl)cc1</smiles>

1f, $90 \%$<smiles>OC/C=C/c1ccc(Cl)cc1</smiles>

5. $84 \%$ $\underset{140^{\circ} \mathrm{C}, 16 \mathrm{~h}}{\stackrel{\mathrm{MeC}(\mathrm{OEt})_{3}, \mathrm{PhOH},}{\longrightarrow}}$

\section{(E)-3-(4-Chlorophenyl)prop-2-en-1-ol (5)}

To a solution of cinnamic acid (913 mg, $5 \mathrm{mmol}, 1.0$ equiv.) in anhydrous PhMe (30 mL) under an atmosphere of argon at $-78{ }^{\circ} \mathrm{C}$ was added $1 \mathrm{M}$ DIBAl-H in $\mathrm{PhMe}(12.5 \mathrm{~mL}, 12.5 \mathrm{mmol} 2.5$ equiv.), and the reaction was stirred at this temperature for $3 \mathrm{~h}$. The reaction was then warmed to rt and $\mathrm{H}_{2} \mathrm{O}(2 \mathrm{~mL})$, then aqueous $1 \mathrm{M} \mathrm{NaOH}$ solution $(15 \mathrm{~mL})$, followed again by $\mathrm{H}_{2} \mathrm{O}(5 \mathrm{~mL})$, were added, with 5 minutes between each addition, maintaining vigorous stirring. The mixture was then poured into a separating funnel, and after phase separation, the aqueous phase was extracted with $\mathrm{PhMe}(2 \times 25 \mathrm{~mL})$. The combined organic layers were then washed with brine, dried over $\mathrm{MgSO}_{4}$, filtered through a plug of silica gel, and the solvent removed in vacuo to yield the title compound as a colourless oil $(707 \mathrm{mg}$, $4.21 \mathrm{mmol}, 84 \%)$ without the requirement for further purification. $\boldsymbol{\delta}_{\mathbf{H}}\left(400 \mathrm{MHz}, \mathrm{CDCl}_{3}\right): 7.33-7.24$ $(\mathrm{m}, 4 \mathrm{H}, \mathrm{Ar}-\mathrm{H}), 6.59$ (d, $\left.J_{1-2}=15.9 \mathrm{~Hz}, 1 \mathrm{H}, \mathrm{H}-1\right), 6.34\left(\mathrm{dt}, J_{2-1}=15.9 \mathrm{~Hz}, J_{2-3}=5.6 \mathrm{~Hz} 1 \mathrm{H}, \mathrm{H}-2\right), 4.33$ 
(app-t, 2H, H-3). LRMS: (ESI) $\mathrm{m} / \mathrm{z}$ calcd for $\mathrm{C}_{9} \mathrm{H}_{8} \mathrm{ClO}$ ([M-H]-): 167.0; found: 167.0. The spectral data were in accordance with those reported in the literature. ${ }^{9}$

\section{Ethyl 3-(4-chlorophenyl)pent-4-enoate (1f)}

General procedure A to yield the title compound (645 mg, $2.71 \mathrm{mmol}, 90 \%$ ) as a colourless oil from 5 (506 mg, $3.00 \mathrm{mmol}$ ) triethyl orthoacetate. Purification was achieved by column chromatography on silica gel using 5\% EtOAc/Hexane (v/v). $\boldsymbol{\delta}_{\mathbf{H}}\left(400 \mathrm{MHz}, \mathrm{CDCl}_{3}\right)$ : 7.31-7.27 (m, 2H, Ar-H), 7.17-7.12 (m, 2H, Ar-H), 6.00-5.88 (m, 1H, H-2), 5.11-5.02 (m, 2H, H-1), 4.07 (q, $\left.J_{5-6}=7.2 \mathrm{~Hz}, 2 \mathrm{H}, \mathrm{H}-5\right), 3.85$ (app-q, 1H, H-3), 2.77-2.61 (m, 2H, H-4), 1.18 (t, $\left.J_{6-5}=7.2 \mathrm{~Hz}, 2 \mathrm{H}, \mathrm{H}-6\right)$. LRMS: (ESI ${ }^{+}$) m/z calcd for $\mathrm{C}_{13} \mathrm{H}_{15} \mathrm{O}_{2} \mathrm{ClK}\left([\mathrm{M}+\mathrm{K}]^{+}\right): 277.0$; found: 277.0 . The spectral data were in accordance with those reported in the literature. ${ }^{8}$

$1 \mathrm{~g}$ was prepared according to the following sequence:
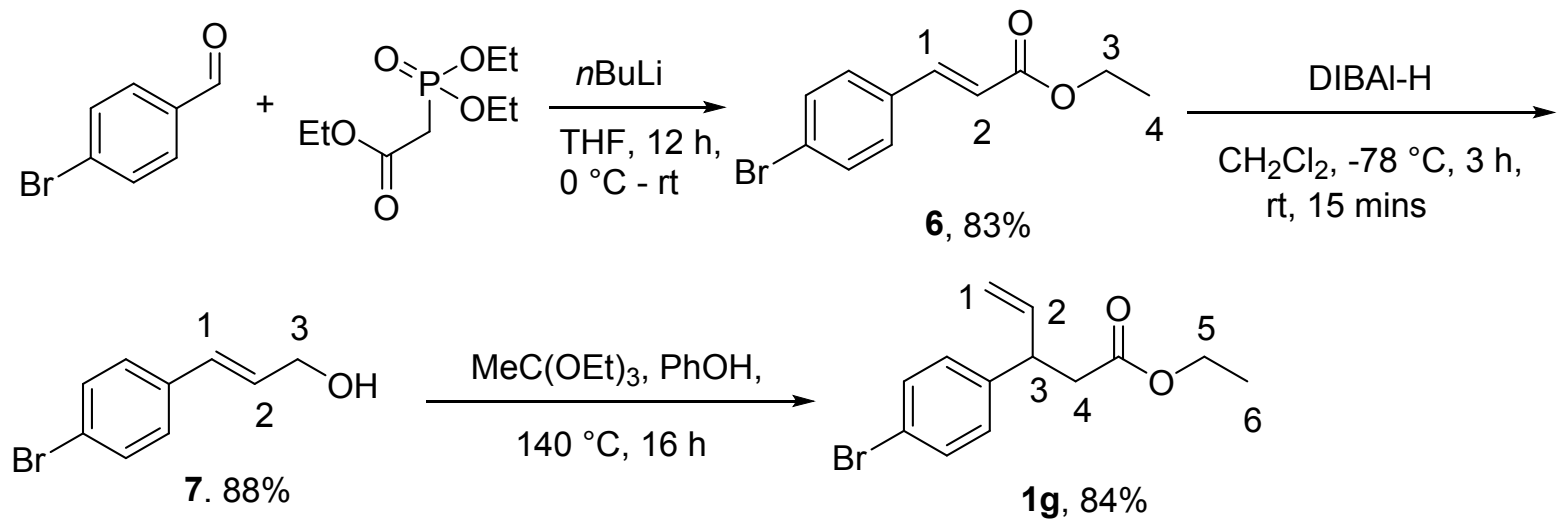

$1 \mathrm{~g}, 84 \%$

\section{ethyl (E)-3-(4-bromophenyl)acrylate (6)}

To triethyl phosphonoacetate $(3.8 \mathrm{~mL}, 19.2 \mathrm{mmol}, 1.2$ equiv.) in anhydrous THF (40 mL) under an atmosphere of argon at $0{ }^{\circ} \mathrm{C}$ was added $2.5 \mathrm{M} n \mathrm{BuLi}$ solution in hexane ( $8.3 \mathrm{~mL}, 20.8 \mathrm{mmol}, 1.3$ equiv.) and the mixture was stirred for $30 \mathrm{~min}$. 4-Bromobenzaldehyde ( $2.96 \mathrm{~g}, 16 \mathrm{mmol}, 1.0$ equiv.) in anhydrous THF $(10 \mathrm{~mL})$ was then added in, and after 10 mins the reaction mixture was allowed to warm to $\mathrm{rt}$, and was stirred for a further $12 \mathrm{~h}$. The reaction was diluted $\mathrm{CH}_{2} \mathrm{Cl}_{2}(250 \mathrm{~mL})$ and quenched with $2 \mathrm{M}$ aqueous $\mathrm{HCl}(40 \mathrm{~mL})$. After phase separation, the aqueous phase was extracted further with $\mathrm{CH}_{2} \mathrm{Cl}_{2}(2 \times 50 \mathrm{~mL})$. The combined organic layers were then washed with brine $(80 \mathrm{~mL})$, dried over $\mathrm{MgSO}_{4}$, filtered and the solvent removed in vacuo to yield the title compound as a fragrent colourless oil without further purification being required. $(3.37 \mathrm{~g}, 13.3 \mathrm{mmol}, 83 \%)$. $\boldsymbol{\delta}_{\mathbf{H}}\left(400 \mathrm{MHz}, \mathrm{CDCl}_{3}\right)$ : 7.60 $\left(\mathrm{d}, J_{1-2}=16.0 \mathrm{~Hz}, 1 \mathrm{H}, \mathrm{H}-1\right), 7.52$ (d, $\left.J_{A r H-A r H}=8.5 \mathrm{~Hz}, 2 \mathrm{H}, \mathrm{Ar}-\mathrm{H}\right), 7.38\left(\mathrm{~d}, J_{A r H-A r H}=8.5 \mathrm{~Hz}, 2 \mathrm{H}, \mathrm{Ar}-\mathrm{H}\right)$, $6.42\left(\mathrm{~d}, J_{2-1}=16.0 \mathrm{~Hz}, 1 \mathrm{H}, \mathrm{H}-2\right), 4.26\left(\mathrm{q}, J_{3-4}=7.1 \mathrm{~Hz}, 2 \mathrm{H}, \mathrm{H}-3\right), 1.33\left(\mathrm{t}, J_{4-3}=7.1 \mathrm{~Hz}, 3 \mathrm{H}, \mathrm{H}-4\right)$. 
LRMS: $\left(\mathrm{ESI}^{+}\right) \mathrm{m} / z$ calcd for $\mathrm{C}_{11} \mathrm{H}_{12} \mathrm{O}_{2} \mathrm{Br}\left([\mathrm{M}+\mathrm{H}]^{+}\right)$: 255.0; found: 255.0. The spectral data were in accordance with those reported in the literature. ${ }^{10}$

\section{(E)-3-(4-bromophenyl)prop-2-en-1-ol (7)}

To a solution of 6 (1.35 g, $5.31 \mathrm{mmol}, 1.0$ equiv.) in anhydrous $\mathrm{CH}_{2} \mathrm{Cl}_{2}(20 \mathrm{~mL})$ under an atmosphere of argon at $-78{ }^{\circ} \mathrm{C}$ was added $1 \mathrm{M}$ DIBAL-H in $\mathrm{CH}_{2} \mathrm{Cl}_{2}$ (11.3 mL, $11.3 \mathrm{mmol} 2.2$ equiv.), and the reaction was stirred at this temperature for $3 \mathrm{~h}$. The reaction was then warmed to $\mathrm{rt}$ and $\mathrm{H}_{2} \mathrm{O}(2 \mathrm{~mL})$, then aqueous $1 \mathrm{M} \mathrm{NaOH}$ solution $(15 \mathrm{~mL})$, followed again by $\mathrm{H}_{2} \mathrm{O}(5 \mathrm{~mL})$, were added, with 5 minutes between each addition, maintaining vigorous stirring. The mixture was then poured into a separating funnel, and after phase separation, the aqueous phase was extracted with $\mathrm{CH}_{2} \mathrm{Cl}_{2}(2 \times 25 \mathrm{~mL})$. The combined organic layers were then washed with brine, dried over $\mathrm{MgSO}_{4}$, filtered through a plug of silica gel, and the solvent removed in vacuo to yield the title compound as a colourless oil $(987 \mathrm{mg}$, $4.65 \mathrm{mmol}, 88 \%)$ without the requirement for further purification. $\boldsymbol{\delta}_{\mathbf{H}}\left(400 \mathrm{MHz}, \mathrm{CDCl}_{3}\right): 7.42\left(\mathrm{~d}, J_{A r H-}\right.$ $\left.{ }_{A r H}=8.4 \mathrm{~Hz}, 2 \mathrm{H}, \mathrm{Ar}-\mathrm{H}\right), 7.23\left(\mathrm{~d}, J_{A r H-A r H}=8.4 \mathrm{~Hz}, 2 \mathrm{H}, \mathrm{Ar}-\mathrm{H}\right), 6.55\left(\mathrm{~d}, J_{I-2}=16.0 \mathrm{~Hz}, 1 \mathrm{H}, \mathrm{H}-1\right), 6.34$ $\left(\mathrm{dt}, J_{2-1}=16.0 \mathrm{~Hz}, J_{2-3}=5.6 \mathrm{~Hz} 1 \mathrm{H}, \mathrm{H}-2\right), 4.31\left(\mathrm{dd}, J_{3-2}=5.6 \mathrm{~Hz}, J_{1-O H}=1.5 \mathrm{~Hz}, 2 \mathrm{H}, \mathrm{H}-1\right)$. LRMS: (ESI-) $m / z$ calcd for $\mathrm{C}_{9} \mathrm{H}_{9} \mathrm{OBr}_{2}\left([\mathrm{M}+\mathrm{Br}]^{-}\right)$: 290.9; found: 290.8 . The spectral data were in accordance with those reported in the literature. ${ }^{11}$

\section{Ethyl 3-(4-bromophenyl)pent-4-enoate (1g)}

General procedure A to yield the title compound $(1.102 \mathrm{~g}, 3.91 \mathrm{mmol}, 84 \%)$ as a colourless oil from 7 (979 mg, $4.64 \mathrm{mmol}$ ) and triethyl orthoacetate. Purification was achieved by column chromatography on silica gel using 10\% EtOAc/Hexane (v/v). $\mathbf{R}_{\mathbf{f}}=0.39\left(10 \%\right.$ EtOAc/Hexane (v/v)). $\boldsymbol{\delta}_{\mathbf{H}}(400 \mathrm{MHz}$, $\left.\mathrm{CDCl}_{3}\right): 7.40\left(\mathrm{~d}, J_{A r H-A r H}=8.5 \mathrm{~Hz}, 2 \mathrm{H}, \mathrm{Ar}-\mathrm{H}\right), 7.07\left(\mathrm{~d}, J_{A r H-A r H}=8.5 \mathrm{~Hz}, 2 \mathrm{H}, \mathrm{Ar}-\mathrm{H}\right), 5.97-5.86(\mathrm{~m}, 1 \mathrm{H}$, H-2), 5.09-5.01 (m, 2H, H-1), 4.05 (q, $J_{5-6}=7.1 \mathrm{~Hz}, 2 \mathrm{H}, \mathrm{H}-5$ ), 3.82 (app-q, 1H, H-3), 2.76-2.59 (m, 2H, H-4), 1.16 (t, $\left.J_{6-5}=7.2 \mathrm{~Hz}, 2 \mathrm{H}, \mathrm{H}-6\right) . \boldsymbol{\delta}_{\mathbf{C}}\left(101 \mathrm{MHz}, \mathrm{CDCl}_{3}\right): 171.5$ (C=O), 141.4 (q, Ar-C), 139.7 (C-2), 131.6, 129.3 (Ar-C), 120.5 (Ar-CBr), 115.2 (C-1), 60.5 (C-5), 44.9 (C-3), 40.0 (C-4), 14.1 (C6). $v_{\max }(\mathrm{ATR}) / \mathrm{cm}^{-1}: 557(\mathrm{C}-\mathrm{Br}), 1165(\mathrm{C}-\mathrm{O}), 1691(\mathrm{C}=\mathrm{O}), 2980(\mathrm{C}-\mathrm{H})$. HRMS: $\left(\mathrm{APCI}^{+}\right) \mathrm{m} / \mathrm{z}$ calcd for $\mathrm{C}_{13} \mathrm{H}_{16} \mathrm{O}_{2} \mathrm{Br}\left([\mathrm{M}+\mathrm{H}]^{+}\right)$: 283.0334; found: 283.0337 .

1h was prepared according to the following sequence:

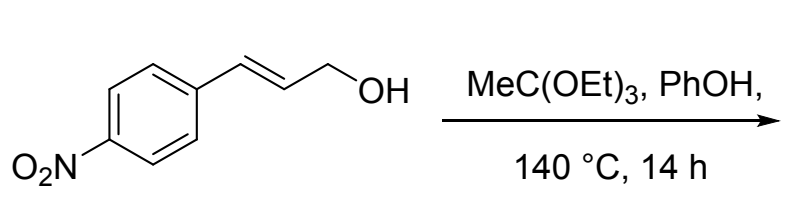<smiles>C=CC(C)c1ccc([N+](=O)[O-])cc1</smiles>

$1 \mathrm{~h}, 76 \%$ 


\section{3-(4-Nitrophenyl)pent-4-enoic acid (1h)}

General procedure A to yield the title compound (625 mg, $2.51 \mathrm{mmol}, 76 \%)$ as a yellow oil from 4nitrocinnamyl alcohol $(590 \mathrm{mg}, 3.30 \mathrm{mmol})$ and triethyl orthoacetate. Purification was achieved by column chromatography on silica gel using $3.0 \rightarrow 7.0 \%$ EtOAc/Hexane $(\mathrm{v} / \mathrm{v}) . \boldsymbol{\delta}_{\mathbf{H}}\left(400 \mathrm{MHz}, \mathrm{CDCl}_{3}\right)$ : 8.19-8.15 (m, 2H, Ar-H), 7.41-7.37 (m, 2H, Ar-H), 6.01-5.89 (m, 1H, H-2), 5.19-5.06 (m, 2H, H-1), 4.07 (q, $\left.J_{5-6}=7.2 \mathrm{~Hz}, 2 \mathrm{H}, \mathrm{H}-5\right), 4.00$ (app-q, 1H, H-3), 2.84-2.67 (m, 2H, H-4), 1.18 (t, $J_{6-5}=7.2 \mathrm{~Hz}$, 2H, H-6). LRMS: $\left(\mathrm{ESI}^{+}\right) \mathrm{m} / \mathrm{z}$ calcd for $\mathrm{C}_{13} \mathrm{H}_{16} \mathrm{NO}_{4}([\mathrm{M}-\mathrm{H}]$ ) $)$ : 250.1; found: 250.1. The spectral data were in accordance with those reported in the literature. ${ }^{12}$

1i was prepared according to the following sequence:<smiles>CCOC(=O)CCC(C)=O</smiles>

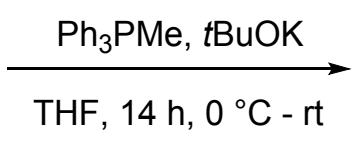

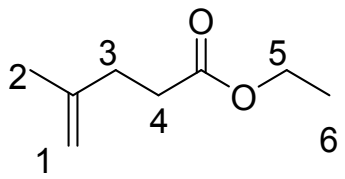

$1 \mathrm{i}, 89 \%$

\section{Ethyl 4-methylpent-4-enoate (1i)}

To a solution of methyltriphenylphosphonium bromide (13.9 g, $39 \mathrm{mmol}, 1.30$ equiv.) in anhydrous THF $(50 \mathrm{~mL})$ under an atmosphere of argon at $0{ }^{\circ} \mathrm{C}$ was added $1 \mathrm{M} t \mathrm{BuOK}(45.5 \mathrm{~mL}, 45.5 \mathrm{mmol}, 1.45$ equiv.) and the mixture was stirred for $30 \mathrm{~min}$. Ethyl levulinate $(4.25 \mathrm{~mL}, 30 \mathrm{mmol}, 1.0$ equiv.) was then added, and after 30 mins the reaction mixture was allowed to warm to rt, and was stirred for a further $14 \mathrm{~h}$. The reaction was diluted $\mathrm{CH}_{2} \mathrm{Cl}_{2}(250 \mathrm{~mL})$ and quenched with $2 \mathrm{M}$ aqueous $\mathrm{HCl}(40 \mathrm{~mL})$. After phase separation, the aqueous phase was extracted further with $\mathrm{CH}_{2} \mathrm{Cl}_{2}(2 \times 50 \mathrm{~mL})$. The combined organic layers were then washed with brine, dried over $\mathrm{MgSO}_{4}$, filtered and the solvent removed in vacuo. Purification was achieved using $15 \%$ EtOAc/Hexane $(\mathrm{v} / \mathrm{v})$ to furnish the title compound as a fragrent colourless oil $(3.75 \mathrm{~g}, 26.4 \mathrm{mmol}, 88 \%)$. $\boldsymbol{\delta}_{\mathbf{H}}\left(400 \mathrm{MHz}, \mathrm{CDCl}_{3}\right): 4.73(\mathrm{~s}, 1 \mathrm{H}, \mathrm{H}-1), 4.67(\mathrm{~s}, 1 \mathrm{H}$, H-1'), 4.19 (q, $J_{5-6}=7.0 \mathrm{~Hz}, 2 \mathrm{H}, \mathrm{H}-5$ ), 2.43 (t, $\left.J_{4-3}=7.5 \mathrm{~Hz}, 2 \mathrm{H}, \mathrm{H}-4\right), 2.32$ (t, $J_{3-4}=7.5 \mathrm{~Hz}, 2 \mathrm{H}, \mathrm{H}-3$ ), 1.73 (s, 3H, H-2), 1.24 (t, $J_{6-5}=7.0 \mathrm{~Hz}, 3 \mathrm{H}, \mathrm{H}-6$ ). LRMS: (ESI-) $m / z$ calcd for $\mathrm{C}_{16} \mathrm{H}_{17} \mathrm{O}_{2}\left([2 \mathrm{M}-\mathrm{H}]^{-}\right)$: 283.2 found: 283.2 . The spectral data were in accordance with those reported in the literature. ${ }^{13}$ 
$\mathbf{1 j}$ was prepared according to the following sequence:

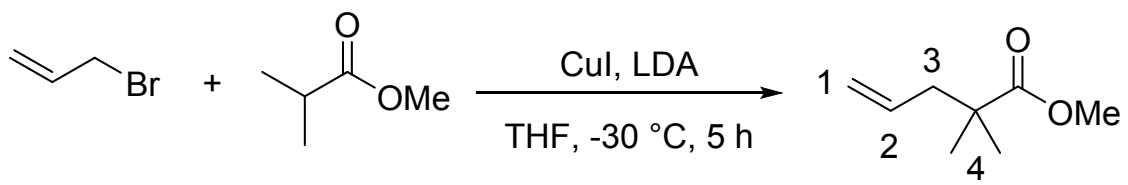

$1 \mathrm{i}, 68 \%$

\section{Methyl 2,2-dimethylpent-4-enoate (1j)}

To a solution of methyl isobutyrate $(0.69 \mathrm{~mL}, 6.0 \mathrm{mmol}, 1.0$ equiv. $)$ and $\mathrm{CuI}(1.80 \mathrm{~g}, 4.2 \mathrm{mmol}, 0.7$ equiv.) in anhydrous THF $(10 \mathrm{~mL})$, under an atmosphere of argon at $-78{ }^{\circ} \mathrm{C}$ was added $2.0 \mathrm{M} \mathrm{LDA}$ solution in hexane (3.6 mL, $7.2 \mathrm{mmol} 1.2$ equiv.) and the mixture was stirred for $30 \mathrm{~min}$. Allyl bromide (1.56 mL, $18 \mathrm{mmol}, 3.0$ equiv.), was added and the mixture stirred at this temperature for $1 \mathrm{~h}$ before being warmed to $-30{ }^{\circ} \mathrm{C}$. After a further $3 \mathrm{~h}$ the reaction mixture was allowed to warm to $\mathrm{rt}$ and was then poured into a separating funnel, diluted with $\mathrm{CH}_{2} \mathrm{Cl}_{2}(60 \mathrm{~mL})$, and quenched with saturated aqueous solution of $\mathrm{NaHCO}_{3}(30 \mathrm{~mL})$. After phase separation, the aqueous phase was washed twice with $\mathrm{CH}_{2} \mathrm{Cl}_{2}$. The combined organic phases were washed with water, then brine, dried over $\mathrm{MgSO}_{4}$, filtered, and the solvent evaporated in vacuo. Purification of the crude product was achieved by column chromatography on silica gel using 10\% EtOAc/Hexane (v/v) to furnish the title compound as a fragment colourless oil (581 mg, 4.09 mmol, 68\%). $\boldsymbol{\delta}_{\mathbf{H}}\left(400 \mathrm{MHz}, \mathrm{CDCl}_{3}\right.$ ): 5.77-5.64 (m, 1H, H-2), 5.06-4.98 (m, 2H, H-1), 3.64 (s, 3H, OMe), 2.26 (d, $\left.J_{3-2}=7.6 \mathrm{~Hz}, 2 \mathrm{H}, \mathrm{H}-3\right), 1.16$ (s, 6H, H-4). LRMS: $\left(\mathrm{ESI}^{+}\right) \mathrm{m} / z$ calcd for $\mathrm{C}_{8} \mathrm{H}_{15} \mathrm{O}_{2}\left([\mathrm{M}+\mathrm{H}]^{+}\right): 143.1$; found: 143.1. The spectral data were in accordance with those reported in the literature. ${ }^{14}$

$1 \mathbf{k}$ was prepared according to the following sequence:<smiles>COc1ccc(CCl)cc1</smiles>

Ethyl 2-(4-methoxybenzyl)-2-methylpent-4-enoate (1k)

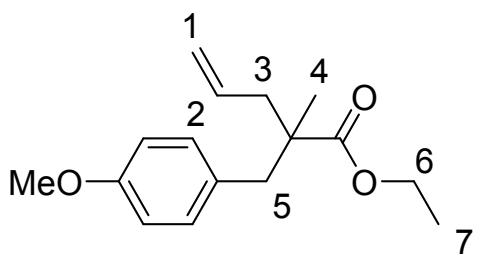

$1 \mathrm{k}, 74 \%$

To a solution of ethyl 2-methyl-4-pentenoate (790 mg, $5.56 \mathrm{mmol}, 1.0$ equiv.) and CuI (530 mg, 278 mmol, 0.5 equiv.) in anhydrous THF $(20 \mathrm{~mL})$, under an atmosphere of argon at $-78{ }^{\circ} \mathrm{C}$ was added 2.0 M LDA solution in hexane ( $3.3 \mathrm{~mL}, 6.6 \mathrm{mmol} 1.2$ equiv.). The mixture was stirred for $30 \mathrm{~min}$ and 4methoxybenzyl chloride (1.5 mL, $11.1 \mathrm{mmol}, 2.0$ equiv.), was added and the mixture stirred at this temperature for $1 \mathrm{~h}$ before being warmed to $-30{ }^{\circ} \mathrm{C}$. After a further $3 \mathrm{~h}$ the reaction mixture was allowed to warm to rt and was then poured into a separating funnel, diluted with $\mathrm{CH}_{2} \mathrm{Cl}_{2}(60 \mathrm{~mL})$, and quenched 
with saturated aqueous solution of $\mathrm{NaHCO}_{3}(30 \mathrm{~mL})$. After phase separation, the aqueous phase was washed twice with $\mathrm{CH}_{2} \mathrm{Cl}_{2}$. The combined organic phases were washed with water, then brine, dried over $\mathrm{MgSO}_{4}$, filtered, and the solvent evaporated in vacuo. Purification of the crude product was achieved by column chromatography on silica gel using 4\% EtOAc/Hexane (v/v) to yield the title compound as a colourless oil (1.08 g, $4.114 \mathrm{mmol}, 74 \%) . \mathbf{R}_{\mathbf{f}}=0.22(10 \%$ EtOAc/Hexane $(\mathrm{v} / \mathrm{v})) . \quad \boldsymbol{\delta}_{\mathbf{H}}$ $\left(400 \mathrm{MHz}, \mathrm{CDCl}_{3}\right): 7.05$ (d, $\left.J_{A r H-A r H}=8.5 \mathrm{~Hz}, 2 \mathrm{H}, \mathrm{Ar}-\mathrm{H}\right), 6.82\left(\mathrm{~d}, J_{A r H-A r H}=8.5 \mathrm{~Hz}, 2 \mathrm{H}, \mathrm{Ar}-\mathrm{H}\right), 5.84$ 5.72 (m, 1H, H-2), 5.13-5.06 (m, 1H, H-2), 4.13 (q, $\left.J_{6-7}=7.1 \mathrm{~Hz}, 2 \mathrm{H}, \mathrm{H}-6\right), 3.80$ (s, 3H, H-4), 2.98 (d, $\left.J_{5-5},=13.5 \mathrm{~Hz}, 1 \mathrm{H}, \mathrm{H}-5\right), 2.69$ (d, $J_{5^{\prime}-5}=13.5 \mathrm{~Hz}, 1 \mathrm{H}, \mathrm{H}-5$ ') 2.52 (dd, $J_{3-3},=13.6 \mathrm{~Hz}, J_{3-2}=6.9 \mathrm{~Hz}, 1 \mathrm{H}$, H-3), 2.17 (dd, $\left.J_{3^{\prime}-3}=13.6 \mathrm{~Hz}, J_{3^{\prime}-2}=7.7 \mathrm{~Hz}, 1 \mathrm{H}, \mathrm{H}-3^{\prime}\right), 1.26$ (t, $\left.J_{7-6}=7.1 \mathrm{~Hz}, 3 \mathrm{H}, \mathrm{H}-7\right), 1.11(\mathrm{~s}, 3 \mathrm{H}$, H-4). $\boldsymbol{\delta}_{\mathbf{C}}\left(101 \mathrm{MHz}, \mathrm{CDCl}_{3}\right): 176.3(\mathrm{C}=\mathrm{O}), 158.3$ (Ar-COMe), 134.1 (C-1), 131.1 (Ar-C), 130.1 (q, ArC), 118.1 (C-1), 113.4 (Ar-C), 60.4 (C-6), 55.2 (OMe), 47.3 (q-C), 44.2 (C-5), 43.4 (C-3), 20.8 (C-4), $14.3(\mathrm{C}-7) \cdot v_{\max }(\mathrm{ATR}) / \mathrm{cm}^{-1}$ : 789 (ArC-H bend), 994 (C=C bend), 1037 (C-O), 1250 (C-O), 1658 $(\mathrm{C}=\mathrm{O}), 2974(\mathrm{C}-\mathrm{H})$. LRMS: $\left(\mathrm{ESI}^{+}\right) \mathrm{m} / z$ calcd for $\mathrm{C}_{16} \mathrm{H}_{23} \mathrm{O}_{3} \mathrm{Na}\left([\mathrm{M}+\mathrm{Na}]^{+}\right)$: 285.1; found: 285.1 .

11 was prepared according to the following sequence:<smiles>FC(F)(F)c1ccc(CBr)cc1</smiles>

Ethyl 2-methyl-2-(4-(trifluoromethyl)benzyl)pent-4-enoate (1l)

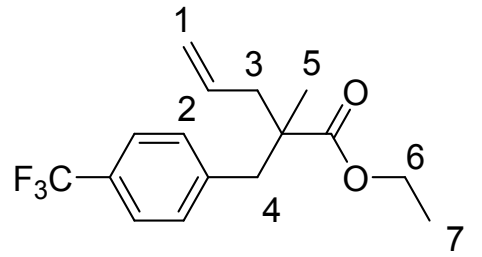

$11,77 \%$

To a solution of ethyl 2-methyl-4-pentenoate $(1.02 \mathrm{~mL}, 6.00 \mathrm{mmol}, 1.0$ equiv.) and $\mathrm{CuI}(572 \mathrm{mg}$, $3.00 \mathrm{mmol}, 0.5$ equiv.) in anhydrous THF $(20 \mathrm{~mL})$, under an atmosphere of argon at $-78^{\circ} \mathrm{C}$ was added 2.0 M LDA solution in hexane ( $3.6 \mathrm{~mL}, 7.2 \mathrm{mmol} 1.2$ equiv.). The mixture was stirred for $30 \mathrm{~min}$ and 4-(trifluoromethyl)benzyl bromide ( $1.16 \mathrm{~mL}, 7.5 \mathrm{mmol}, 1.25$ equiv.), was added and the mixture stirred at this temperature for $1 \mathrm{~h}$ before being warmed to $-30{ }^{\circ} \mathrm{C}$. After a further $3 \mathrm{~h}$ the reaction mixture was allowed to warm to $\mathrm{rt}$ and was then poured into a separating funnel, diluted with $\mathrm{CH}_{2} \mathrm{Cl}_{2}(60 \mathrm{~mL})$, and quenched with saturated aqueous solution of $\mathrm{NaHCO}_{3}(30 \mathrm{~mL})$. After phase separation, the aqueous phase was washed twice with $\mathrm{CH}_{2} \mathrm{Cl}_{2}$. The combined organic phases were washed with water, then brine, dried over $\mathrm{MgSO}_{4}$, filtered, and the solvent evaporated in vacuo. Purification of the crude product was achieved by column chromatography on silica gel using $2.5 \rightarrow 5.0 \%$ EtOAc/Hexane (v/v) to yield the title compound as a colourless oil (1.39 g, $4.64 \mathrm{mmol}, 77 \%) . \mathbf{R}_{\mathbf{f}}=0.26(10 \%$ EtOAc/Hexane (v/v)). $\boldsymbol{\delta}_{\mathbf{H}}\left(400 \mathrm{MHz}, \mathrm{CDCl}_{3}\right): 7.54\left(\mathrm{~d}, J_{A r H-A r H}=8.0 \mathrm{~Hz}, 2 \mathrm{H}, \mathrm{Ar}-\mathrm{H}\right), 7.26\left(\mathrm{~d}, J_{A r H-A r H}=8.0 \mathrm{~Hz}, 2 \mathrm{H}, \mathrm{Ar}-\mathrm{H}\right), 5.85-$ $5.72(\mathrm{~m}, 1 \mathrm{H}, \mathrm{H}-2), 5.16-5.09(\mathrm{~m}, 2 \mathrm{H}, \mathrm{H}-1), 4.14\left(\mathrm{q}, J_{6-7}=7.1 \mathrm{~Hz}, 2 \mathrm{H}, \mathrm{H}-6\right), 3.11\left(\mathrm{~d}, J_{4-4}=13.2 \mathrm{~Hz}, 1 \mathrm{H}\right.$, H-4), 2.79 (d, $\left.J_{4^{\prime}-4}=13.2 \mathrm{~Hz}, 1 \mathrm{H}, \mathrm{H}-4^{\prime}\right), 2.52\left(\mathrm{dd}, J_{3-3}{ }^{\prime}=13.4 \mathrm{~Hz}, J_{3-2}=7.2 \mathrm{~Hz}, 1 \mathrm{H}, \mathrm{H}-3\right), 2.22$ (dd, $J_{3^{\prime}}$ ' 
$\left.{ }_{3}=13.4 \mathrm{~Hz}, J_{3^{\prime}-2}=7.6 \mathrm{~Hz}, 1 \mathrm{H}, \mathrm{H}-3^{\prime}\right), 1.25\left(\mathrm{t}, J_{7-6}=7.1 \mathrm{~Hz}, 3 \mathrm{H}, \mathrm{H}-7\right), 1.13(\mathrm{~s}, 3 \mathrm{H}, \mathrm{H}-5) . \boldsymbol{\delta}_{\mathrm{C}}(101 \mathrm{MHz}$, $\mathrm{CDCl}_{3}$ ): $175.8(\mathrm{C}=\mathrm{O}), 141.8$ (q, Ar-C), $133.6(\mathrm{C}-2), 130.5$ (Ar-C), 128.8 (q, $J_{A r C-F}=33.0 \mathrm{~Hz}, \mathrm{q}, \mathrm{Ar}-\mathrm{C}$ ), 124.9 (q, $\left.J_{A r C-F}=3.6 \mathrm{~Hz}, \mathrm{Ar}-\mathrm{C}\right), 124.3$ (q, $J_{C-F}=272.6 \mathrm{~Hz}, \mathrm{CF}_{3}$ ), 118.6 (C-1), 60.6 (C-6), 47.2 (q-C), 44.6 (C-4), 43.6 (C-3), 20.9 (C-5), 14.2 (C-7). $\boldsymbol{\delta}_{\mathbf{F}}\left(377 \mathrm{MHz}, \mathrm{CDCl}_{3}\right):-62.5 . \boldsymbol{v}_{\max }(\mathrm{ATR}) / \mathrm{cm}^{-1}: 812(\mathrm{ArC}-$ $\mathrm{H}$ bend), 996 (C=C bend), $1216(\mathrm{C}-\mathrm{O}), 1641(\mathrm{C}=\mathrm{C}), 1725(\mathrm{C}=\mathrm{O}), 2982(\mathrm{C}-\mathrm{H})$. HRMS: $\left(\mathrm{APCI}^{+}\right) \mathrm{m} / \mathrm{z}$ calcd for $\mathrm{C}_{16} \mathrm{H}_{20} \mathrm{O}_{2} \mathrm{~F}_{3}\left([\mathrm{M}+\mathrm{H}]^{+}\right)$: 301.1415; found: 301.1412 .

1m was prepared according to the following sequence:<smiles>O=Cc1ccco1</smiles><smiles>C=CCC(C)C(=O)OCC</smiles>

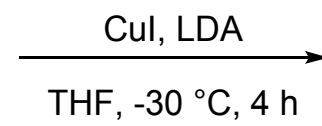<smiles>C=CCC(C)(C(=O)OCC)C(O)c1ccco1</smiles>

$\mathrm{NaH}, \mathrm{Mel}$ THF, rt, $16 \mathrm{~h}$<smiles>C=CCC(C)(C(=O)OCC)C(C)OCC</smiles>

$8,73 \%$ dr 1:1.1

$1 \mathrm{~m}, 84 \%$

dr 1:1.1

\section{Ethyl 2-(furan-2-yl(hydroxy)methyl)-2-methylpent-4-enoate (8)}

To a solution of ethyl 2-methyl-4-pentenoate $(1.02 \mathrm{~mL}, 6.00 \mathrm{mmol}, 1.0$ equiv.) and $\mathrm{CuI}(229 \mathrm{mg}$, $1.20 \mathrm{mmol}, 0.2$ equiv.) in anhydrous THF $(20 \mathrm{~mL})$, under an atmosphere of argon at $-78^{\circ} \mathrm{C}$ was added 2.0 M LDA solution in hexane ( $3.6 \mathrm{~mL}, 7.2 \mathrm{mmol} 1.2$ equiv.). The mixture was stirred for $30 \mathrm{~min}$ and furfural ( $0.63 \mathrm{~mL}, 6.5 \mathrm{mmol}, 1.08$ equiv.), was added and the mixture stirred at this temperature for 1 $\mathrm{h}$ before being warmed to $-30{ }^{\circ} \mathrm{C}$. After a further $3 \mathrm{~h}$ the reaction mixture was allowed to warm to $\mathrm{rt}$ and was then poured into a separating funnel, diluted with $\mathrm{CH}_{2} \mathrm{Cl}_{2}(60 \mathrm{~mL})$, and quenched with saturated aqueous solution of $\mathrm{NaHCO}_{3}(30 \mathrm{~mL})$. After phase separation, the aqueous phase was washed twice with $\mathrm{CH}_{2} \mathrm{Cl}_{2}$. The combined organic phases were washed with water, then brine, dried over $\mathrm{MgSO}_{4}$, filtered, and the solvent evaporated in vacuo. Purification of the crude product was achieved by column chromatography on silica gel using $10 \%$ EtOAc/Hexane $(\mathrm{v} / \mathrm{v})$ to yield the title compound as an inseparable mixture of diasteroisomers $(1.1: 1,1.04 \mathrm{~g}, 4.351 \mathrm{mmol}, 73 \%)$ as a yellow oil. $\mathbf{R}_{\mathbf{f}}=0.12$ $(10 \% \mathrm{EtOAc} / \mathrm{Hexane}(\mathrm{v} / \mathrm{v}))$. Indistinguishable mixture of isomer $\boldsymbol{\delta}_{\mathbf{H}}\left(400 \mathrm{MHz}, \mathrm{CDCl}_{3}\right): 7.39-7.36$ (m, 2H, Ar-H), 6.37-6.34 (m, 2H, Ar-H), 6.29-6.26 (m, 2H, Ar-H), 5.88-5.70 (m, 2H, H-2), 5.16-5.06 (m, 4H, H-1), 4.86 (s, 1H, H-5), 4.77 (s, 1H, H-5), 4.27-4.15 (m, 4H, H-6), 3.56 (s, 1H, OH), 3.23 (s, $1 \mathrm{H}, \mathrm{OH}), 2.62\left(\mathrm{dd}, J_{3-3},=14.1 \mathrm{~Hz}, J_{3-2}=7.0 \mathrm{~Hz}, 1 \mathrm{H}, \mathrm{H}-3\right), 2.54\left(\mathrm{dd}, J_{3-3}=14.1 \mathrm{~Hz}, J_{3-2}=7.3 \mathrm{~Hz}, 1 \mathrm{H}\right.$, 
H-3), 2.33-2.25 (m, 2H, H-3'), 1.31 (t, $J_{7-6}=7.1 \mathrm{~Hz}, 3 \mathrm{H}, \mathrm{H}-7$ ), 1.28 (t, $\left.J_{7-6}=7.1 \mathrm{~Hz}, 3 \mathrm{H}, \mathrm{H}-7\right), 1.22$ (s, 3H, H-4), 1.14 (s, 3H, H-4). $\boldsymbol{\delta}_{\mathrm{C}}\left(151 \mathrm{MHz}, \mathrm{CDCl}_{3}\right): 176.2,175.7$ (C=O), 153.9, 153.8 (q, Ar-C), 141.9, 141.8 (Ar-C), 133.8, 132.8 (C-2), 118.9, 118.4 (C-1), 110.2, 110.2, 108.0, 107.8 (Ar-C), 72.8, 72.4 (C5), 61.0, 60.9 (C-6), 50.6, 50.6 (q-C), 41.2, 39.6 (C-3), 18.3, 17.4 (C-4), 14.2, 14.1 (C-7). $v_{\max }$ (ATR)/cm- ${ }^{-1}: 734$ (ArC-H bend), 1096 (C-O), 1144 (ArC-O), 1640 (C=C), 1718 (C=O), 2982 (C-H), 3476 (O-H). LRMS: $\left(\mathrm{ESI}^{+}\right) \mathrm{m} / z$ calcd for $\mathrm{C}_{13} \mathrm{H}_{28} \mathrm{O}_{4} \mathrm{~K}\left([\mathrm{M}+\mathrm{K}]^{+}\right)$: 277.1; found: 277.1.

\section{Ethyl 2-(furan-2-yl(methoxy)methyl)-2-methylpent-4-enoate (1m)}

To a stirred solution of 8 ( $850 \mathrm{mg}, 3.57 \mathrm{mmol}, 1.00$ equiv) and MeI (0.45 mL, $7.14 \mathrm{mmol}, 1.25$ equiv.) in anhydrous THF $(20 \mathrm{~mL})$ under an atmosphere of argon at $0{ }^{\circ} \mathrm{C}$ was added $60 \% \mathrm{NaH}$ in mineral oil (179 mg, $4.46 \mathrm{mmol}, 1.25$ equiv.). The mixture was stirred at this temperature for $30 \mathrm{~min}$, then warmed to rt. After $16 \mathrm{~h}$ the reaction was diluted with $\mathrm{CH}_{2} \mathrm{Cl}_{2}(60 \mathrm{~mL})$, quenched with $1 \mathrm{M}$ aqueous $\mathrm{HCl}$ solution $(15 \mathrm{~mL})$ and poured into a separating funnel. After phase separation, the aqueous phase was washed twice with $\mathrm{CH}_{2} \mathrm{Cl}_{2}$. The combined organic phases were washed with brine, dried over $\mathrm{MgSO}_{4}$, filtered, and the solvent evaporated in vacuo. Purification of the crude product was achieved by column chromatography on silica gel using $10 \%$ EtOAc/Hexane $(\mathrm{v} / \mathrm{v})$ to yield the title compound as an inseparable mixture of diasteroisomers $(1.1: 1,0.756 \mathrm{~g}, 3.00 \mathrm{mmol}, 84 \%)$ as a colourless oil. $\mathbf{R}_{\mathbf{f}}=0.24$ $(10 \% \mathrm{EtOAc} / \mathrm{Hexane}(\mathrm{v} / \mathrm{v}))$. Indistinguishable mixture of isomer $\boldsymbol{\delta}_{\mathbf{H}}\left(600 \mathrm{MHz}, \mathrm{CDCl}_{3}\right): 7.46-7.44$ (m, 1H, Ar-H), 7.41-7.39 (m, 1H, Ar-H), 6.41-7.38 (m, 1H, Ar-H), 6.37-6.33 (m, 2H, Ar-H), 6.28 (d, $\left.J_{A r H-A r H}=3.3 \mathrm{~Hz}, 1 \mathrm{H}, \mathrm{Ar}-\mathrm{H}\right), 5.84-5.75(\mathrm{~m}, 1 \mathrm{H}, \mathrm{H}-2), 5.69-5.60$ (m, 1H, H-2), 5.11-4.97 (m, 4H, H1), 4.59 (s, 1H, H-5), 4.50 (s, 1H, H-5), 4.27-4.07 (m, 4H, H-6), 3.29 (s, 3H, OMe), 3.23 (s, 3H, OMe), $2.66\left(\mathrm{dd}, J_{3-3},=13.7 \mathrm{~Hz}, J_{3-2}=7.0 \mathrm{~Hz}, 1 \mathrm{H}, \mathrm{H}-3\right), 2.42-2.34\left(\mathrm{~m}, 2 \mathrm{H}, \mathrm{H}-3, \mathrm{H}-3\right.$ ') 1.87 (dd, $J_{3-3}{ }^{\prime}=13.8$ $\mathrm{Hz}, J_{3-2}=7.6 \mathrm{~Hz}, 1 \mathrm{H}, \mathrm{H}-3$ ') 1.30 (t, $\left.J_{7-6}=7.1 \mathrm{~Hz}, 3 \mathrm{H}, \mathrm{H}-7\right), 1.25-1.21$ (m, 6H, H-4, H-7), 1.16 (s, 3H, $\mathrm{H}-4)$. $\boldsymbol{\delta}_{\mathbf{C}}\left(151 \mathrm{MHz}, \mathrm{CDCl}_{3}\right.$ ): 174.8, 174.3 (C=O), 152.1, 151.6 (q, Ar-C), 142.5, 142.3 (Ar-C), 134.4, 133.1 (C-2), 118.2, 117.9 (C-1), 110.1, 110.0, 109.9, 109.3 (Ar-C), 81.8, 81.6 (C-5), 60.6, 60.5 (C-6), 57.8, 57.4 (OMe), 51.5, 51.5 (q-C), 40.9, 40.4 (C-3), 16.7, 15.5 (C-4), 14.3, 14.2 (C-7). $\mathbf{v}_{\max }$ (ATR)/cm': 737 (ArC-H bend), $1095(\mathrm{C}=\mathrm{O}), 1145$ (ArC-O), $1641(\mathrm{C}=\mathrm{C}), 1736(\mathrm{C}=\mathrm{O}), 2982$ (C-H). HRMS: (ESI) $\mathrm{m} / z$ calcd for $\mathrm{C}_{14} \mathrm{H}_{19} \mathrm{O}_{4}\left([\mathrm{M}-\mathrm{H}]^{-}\right)$: 251.1; found: 251.1 .

1n was prepared according to the following sequence: 
<smiles>CC(C)=CCO</smiles>

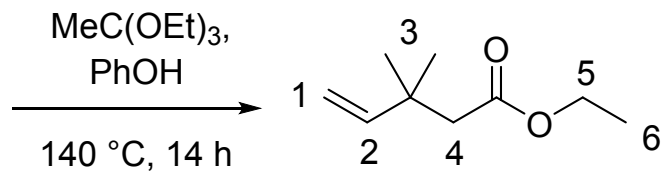

1n, $80 \%$

\section{Ethyl 3,3-dimethylpent-4-enoate (1n)}

General procedure A to yield the title compound $(1.45 \mathrm{~g}, 9.32 \mathrm{mmol}, 80 \%)$ as a colourless oil from prenol and triethyl orthoacetate. Purification was achieved by column chromatography on silica gel using $3 \rightarrow 6 \%$ EtOAc/Hexane (v/v). $\boldsymbol{\delta}_{\mathbf{H}}\left(400 \mathrm{MHz}, \mathrm{CDCl}_{3}\right): 5.90\left(\mathrm{dd}, J_{2-1}=16.7 \mathrm{~Hz}, J_{2-1}=10.8 \mathrm{~Hz}, 1 \mathrm{H}\right.$, H-2), 5.01-4.91 (m, 2H, H-1), 4.10 (q, $J_{5-6}=7.2 \mathrm{~Hz}, 2 \mathrm{H}, \mathrm{H}-5$ ), 2.28 (s, 2H, H-4), 1.24 (t, $J_{6-5}=7.2 \mathrm{~Hz}$, $3 \mathrm{H}, \mathrm{H}-6), 1.13$ ( $\mathrm{s}, 6 \mathrm{H}, \mathrm{H}-3$ ). LRMS: (ESI $\left.{ }^{-}\right) \mathrm{m} / \mathrm{z}$ calcd for $\mathrm{C}_{9} \mathrm{H}_{17} \mathrm{O}_{2}\left([\mathrm{M}+\mathrm{H}]^{+}\right): 157.1$; found: 157.1. The spectral data were in accordance with those reported in the literature. ${ }^{15}$

10 was prepared according to the following sequence:<smiles>CCCCOP(=O)(CC(=O)OCC)OCC</smiles><smiles>CCOC(=O)/C=C(\I)c1ccccc1</smiles><smiles>OC/C=C(\I)c1ccccc1</smiles>

$10,84 \%$

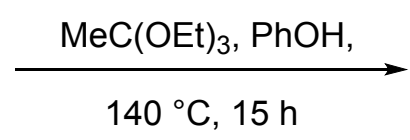

$140{ }^{\circ} \mathrm{C}, 15 \mathrm{~h}$

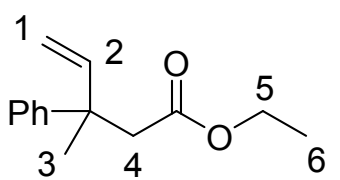

$10,93 \%$

\section{Ethyl (E)-3-phenylbut-2-enoate (9)}

To triethyl phosphonoacetate $(2.4 \mathrm{~mL}, 12.0 \mathrm{mmol}, 1.2$ equiv.) in anhydrous THF (20 mL) under an atmosphere of argon at $0{ }^{\circ} \mathrm{C}$ was added $2 \mathrm{M} n \mathrm{BuLi}$ solution in hexane $(6.5 \mathrm{~mL}, 13.0 \mathrm{mmol}, 1.3$ equiv.) and the mixture was stirred for $30 \mathrm{~min}$. Acetophenone ( $1.2 \mathrm{~mL}, 10 \mathrm{mmol}, 1.0$ equiv.) in anhydrous THF $(5 \mathrm{~mL})$ was then added. After 10 mins the reaction mixture was allowed to warm to $\mathrm{rt}$, and was stirred for a further $13 \mathrm{~h}$. The reaction was diluted $\mathrm{CH}_{2} \mathrm{Cl}_{2}(200 \mathrm{~mL})$ and quenched with $2 \mathrm{M}$ aqueous $\mathrm{HCl}(40$ $\mathrm{mL})$. After phase separation, the aqueous phase was extracted further with $\mathrm{CH}_{2} \mathrm{Cl}_{2}(2 \times 50 \mathrm{~mL})$. The combined organic layers were then washed with brine $(80 \mathrm{~mL})$, dried over $\mathrm{MgSO}_{4}$, filtered and the solvent removed in vacuo to yield the title compound as a fragrent colourless oil (E:Z; 5:1, $1.52 \mathrm{~g}, 7.99$ mmol, 80\%) without further purification being required. $\boldsymbol{\delta}_{\mathbf{H}}\left(400 \mathrm{MHz}, \mathrm{CDCl}_{3}\right): 7.50-7.43(\mathrm{~m}, 2 \mathrm{H}, \mathrm{Ar}-$ H), 7.38-7.33 (m, 3H, Ar-H), 6.12 (s, 1H, H-2) 4.20 (q, $\left.J_{3-4}=7.1 \mathrm{~Hz}, 2 \mathrm{H}, \mathrm{H}-3\right), 2.56$ (s, 3H, H-1), 1.30 
(t, $\left.J_{4-3}=7.1 \mathrm{~Hz}, 3 \mathrm{H}, \mathrm{H}-4\right)$. LRMS: $\left(\mathrm{ESI}^{+}\right) \mathrm{m} / z$ calcd for $\mathrm{C}_{12} \mathrm{H}_{15} \mathrm{O}_{2}\left([\mathrm{M}+\mathrm{H}]^{+}\right): 191.1$; found: 191.1. The spectral data were in accordance with those reported in the literature. ${ }^{16}$

\section{(E)-3-Phenylbut-2-en-1-ol (10)}

To a solution of 9 (1.17 g, $6.16 \mathrm{mmol}, 1.0$ equiv.) in anhydrous $\mathrm{CH}_{2} \mathrm{Cl}_{2}(20 \mathrm{~mL})$ under an atmosphere of argon at $-78^{\circ} \mathrm{C}$ was added $1 \mathrm{M}$ DIBAl- $\mathrm{H}$ in $\mathrm{CH}_{2} \mathrm{Cl}_{2}$ (13.5 mL, $13.5 \mathrm{mmol} 2.2$ equiv.), and the reaction was stirred at this temperature for $3 \mathrm{~h}$. The reaction was then warmed to $\mathrm{rt}$ and $\mathrm{H}_{2} \mathrm{O}(2 \mathrm{~mL})$, then aqueous $1 \mathrm{M} \mathrm{NaOH}$ solution $(15 \mathrm{~mL})$, followed again by $\mathrm{H}_{2} \mathrm{O}(5 \mathrm{~mL})$, were added, with 5 minutes between each addition, maintaining vigorous stirring. The mixture was then poured into a separating funnel, and after phase separation, the aqueous phase was extracted with $\mathrm{CH}_{2} \mathrm{Cl}_{2}(2 \times 25 \mathrm{~mL})$. The combined organic layers were then washed with brine, dried over $\mathrm{MgSO}_{4}$, filtered through a plug of silica gel, and the solvent removed in vacuo to yield the title compound as a colourless oil (764 mg, $5.162 \mathrm{mmol}, 84 \%$ ) without the requirement for further purification. $\boldsymbol{\delta}_{\mathbf{H}}\left(400 \mathrm{MHz}, \mathrm{CDCl}_{3}\right): 7.41-7.22(\mathrm{~m}, 5 \mathrm{H}, \mathrm{Ar}-\mathrm{H}), 5.96$ $\left(\mathrm{t}, J_{2-3}=6.7 \mathrm{~Hz}, 1 \mathrm{H}, \mathrm{H}-2\right), 4.36\left(\mathrm{~d}, J_{3-2}=6.7 \mathrm{~Hz}, 2 \mathrm{H}, \mathrm{H}-3\right), 2.08$ (s, 3H, H-1). LRMS: $\left(\mathrm{ESI}^{+}\right) \mathrm{m} / z$ calcd for $\mathrm{C}_{10} \mathrm{H}_{12} \mathrm{ONa}\left([\mathrm{M}+\mathrm{Na}]^{+}\right): 171.1$; found: 171.1 . The spectral data were in accordance with those reported in the literature. ${ }^{17}$

\section{Ethyl 3-methyl-3-phenylpent-4-enoate (1o)}

General procedure A to yield the title compound $(667 \mathrm{mg}, 3.060 \mathrm{mmol}, 93 \%)$ as a colourless oil from 10 (486 mg, $3.27 \mathrm{mmol}$ ) and triethyl orthoacetate. Purification was achieved by column chromatography on silica gel using 3.5\% EtOAc/Hexane (v/v). $\boldsymbol{\delta}_{\mathbf{H}}\left(400 \mathrm{MHz}, \mathrm{CDCl}_{3}\right): 7.35-7.25$ (m, $5 \mathrm{H}, \mathrm{Ar}-\mathrm{H}), 6.14\left(\mathrm{dd}, J_{2-1}=17.4 \mathrm{~Hz}, J_{2-1}=10.8 \mathrm{~Hz}, 1 \mathrm{H}, \mathrm{H}-2\right), 5.15-5.03(\mathrm{~m}, 2 \mathrm{H}, \mathrm{H}-1), 3.79$ (q, $J_{5-6}=7.2$ Hz, 2H, H-5), 2.76 (app-q, 2H, H-4), 1.55 (s, 3H, H-3), 1.08 (t, $J_{6-5}=7.2$ Hz, 3H, H-6). LRMS: (ESI $\left.{ }^{+}\right)$ $\mathrm{m} / \mathrm{z}$ calcd for $\mathrm{C}_{14} \mathrm{H}_{18} \mathrm{O}_{2} \mathrm{Na}\left([\mathrm{M}+\mathrm{Na}]^{+}\right): 241.1$; found: 241.1 . The spectral data were in accordance with those reported in the literature. ${ }^{18}$

1p was prepared according to the following sequence: 


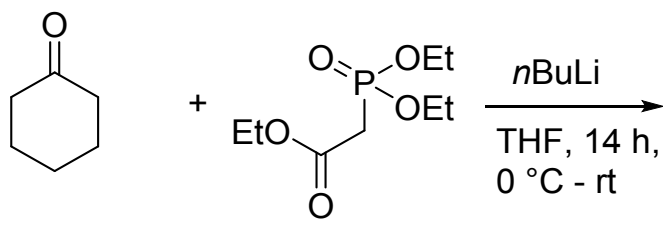<smiles>OC([Te])C=C1CCCCC1</smiles>

12. $90 \%$

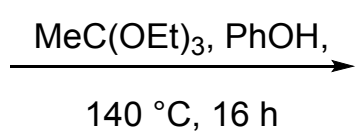

$140{ }^{\circ} \mathrm{C}, 16 \mathrm{~h}$

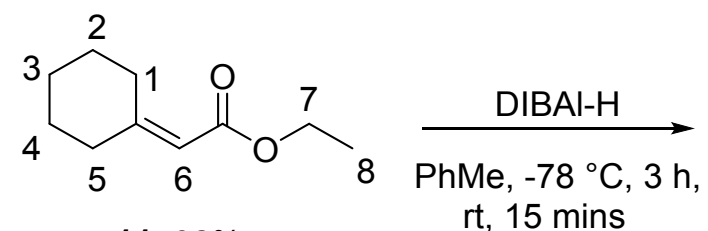

$11,92 \%$ rt, 15 mins

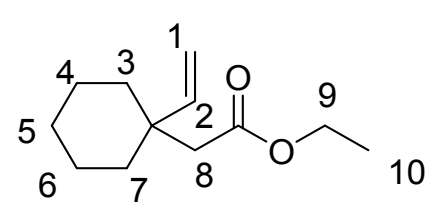

$1 p, 91 \%$

\section{Ethyl 2-cyclohexylideneacetate (11)}

To triethyl phosphonoacetate $(2.4 \mathrm{~mL}, 12 \mathrm{mmol}, 1.2$ equiv.) in anhydrous THF $(50 \mathrm{~mL})$ under an atmosphere of argon at $0{ }^{\circ} \mathrm{C}$ was added $2.5 \mathrm{MnBuLi}(6 \mathrm{~mL}, 15 \mathrm{mmol}, 1.5$ equiv.) and the mixture was stirred for $30 \mathrm{~min}$. Cyclohexanone (1.03 mL, $10 \mathrm{mmol}, 1.0$ equiv.) was then added, and after $10 \mathrm{~min}$, the reaction mixture was allowed to warm to $\mathrm{rt}$, and was stirred for a further $14 \mathrm{~h}$. The reaction was diluted $\mathrm{CH}_{2} \mathrm{Cl}_{2}(250 \mathrm{~mL})$ and quenched with $2 \mathrm{M}$ aqueous $\mathrm{HCl}(40 \mathrm{~mL})$. After phase separation, the aqueous phase was extracted further with $\mathrm{CH}_{2} \mathrm{Cl}_{2}(2 \times 50 \mathrm{~mL})$. The combined organic layers were then washed with brine, dried over $\mathrm{MgSO}_{4}$, filtered and the solvent removed in vacuo. Purification was achieved by column chromatography on silica gel using $3.0 \rightarrow 4.0 \%$ EtOAc/Hexane (v/v) to afford the title compound as colourless oil (1.546 g, $9.21 \mathrm{mmol}, 92 \%)$. $\boldsymbol{\delta}_{\mathbf{H}}\left(400 \mathrm{MHz}, \mathrm{CDCl}_{3}\right): 5.58$ (s, 1H, H-6), 4.12 (q, $\left.J_{7-8}=7.2 \mathrm{~Hz}, 2 \mathrm{H}, \mathrm{H}-7\right), 2.81$ (t, $\left.J_{5-4}=5.5 \mathrm{~Hz}, 2 \mathrm{H}, \mathrm{H}-5\right), 2.17$ (t, $J_{1-2}=5.9 \mathrm{~Hz}, 2 \mathrm{H}, \mathrm{H}-1$ ), $1.67-$ $1.52(\mathrm{~m}, 6 \mathrm{H}, \mathrm{H}-2, \mathrm{H}-3, \mathrm{H}-4), 1.26$ (t, $\left.J_{8-7}=7.2 \mathrm{~Hz}, 3 \mathrm{H}, \mathrm{H}-8\right)$. LRMS: $\left(\mathrm{ESI}^{+}\right) \mathrm{m} / z$ calcd for $\mathrm{C}_{10} \mathrm{H}_{15} \mathrm{O}_{2} \mathrm{Na}_{2}$ $\left([\mathrm{M}+2 \mathrm{Na}-\mathrm{H}]^{+}\right): 213.1$; found: 213.1 . The spectral data were in accordance with those reported in the literature. ${ }^{19}$

\section{2-Cyclohexylideneethan-1-ol (12)}

To a solution of 11 (1.18 g, $7.0 \mathrm{mmol}, 1.0$ equiv.) in anhydrous $\mathrm{PhMe}(56 \mathrm{~mL})$ under an atmosphere of argon at $-78{ }^{\circ} \mathrm{C}$ was added $1 \mathrm{M}$ DIBAl-H in PhMe (17.5 mL, $17.5 \mathrm{mmol} 2.5$ equiv.), and the reaction was stirred at this temperature for $3 \mathrm{~h}$. The reaction mixture was warmed to $\mathrm{rt}$ and $\mathrm{H}_{2} \mathrm{O}(2 \mathrm{~mL})$, then aqueous $1 \mathrm{M} \mathrm{NaOH}$ solution $(15 \mathrm{~mL})$, followed again by $\mathrm{H}_{2} \mathrm{O}(5 \mathrm{~mL})$, were added, with 5 minutes between each addition, maintaining vigorous stirring. The mixture was then poured into a separating funnel, and after phase separation, the aqueous phase was extracted with PhMe (2 x $25 \mathrm{~mL})$. The combined organic layers were then washed with brine, dried over $\mathrm{MgSO}_{4}$, filtered through a plug of silica gel, and the solvent removed in vacuo to yield the title compound as a colourless oil (794 mg, $6.31 \mathrm{mmol}, 90 \%)$ without the requirement for further purification. $\boldsymbol{\delta}_{\mathbf{H}}\left(400 \mathrm{MHz}, \mathrm{CDCl}_{3}\right): 5.35\left(\mathrm{t}, J_{6-7}=\right.$ $7.0 \mathrm{~Hz}, 1 \mathrm{H}, \mathrm{H}-6$ ), 4.12 (app-t, 2H, H-7), 2.17 (t, $\left.J_{5-4}=5.2 \mathrm{~Hz}, 2 \mathrm{H}, \mathrm{H}-5\right), 2.12-2.07$ (m, 2H, H-1), 1.581.47 (m, 6H, H-2, H-3, H-4), 1.08 (t, $\left.J_{\mathrm{OH}-7}=5.1 \mathrm{~Hz}, 1 \mathrm{H}, \mathrm{OH}\right)$. LRMS: $\left(\mathrm{ESI}^{+}\right) \mathrm{m} / z$ calcd for $\mathrm{C}_{8} \mathrm{H}_{14} \mathrm{OK}$ 
$\left([\mathrm{M}+\mathrm{K}]^{+}\right)$: 165.1 ; found: 165.1 . The spectral data were in accordance with those reported in the literature. ${ }^{19}$

\section{Ethyl 2-(1-vinylcyclohexyl)acetate (1p)}

General procedure A to yield the title compound (600 $\mathrm{mg}, 4.33 \mathrm{mmol}, 91 \%)$ as a colourless oil from 12 (600 mg, $4.76 \mathrm{mmol})$ and triethyl orthoacetate. Purification was achieved by column chromatography on silica gel using $2.5 \rightarrow 5.0 \%$ EtOAc/Hexane (v/v). $\boldsymbol{\delta}_{\mathbf{H}}\left(400 \mathrm{MHz}, \mathrm{CDCl}_{3}\right): 5.76\left(\mathrm{dd}, J_{2-1}=17.6 \mathrm{~Hz}\right.$, $\left.J_{2-1}=10.9 \mathrm{~Hz}, 1 \mathrm{H}, \mathrm{H}-2\right), 5.11-4.95$ (m, 2H, H-1), 4.07 (q, $J_{9-10}=7.2 \mathrm{~Hz}, 2 \mathrm{H}, \mathrm{H}-9$ ), 2.29 (s, 2H, H-8), 1.68-1.41 (m, 10H, H-3, H-4, H-5, H-6, H-7), 1.21 (t, $J_{10-9}=7.2$ Hz, 3H, H-10). LRMS: $\left(\mathrm{ESI}^{+}\right) \mathrm{m} / \mathrm{z}$ calcd for $\mathrm{C}_{12} \mathrm{H}_{20} \mathrm{O}_{2} \mathrm{~K}\left([\mathrm{M}+\mathrm{K}]^{+}\right)$: 235.1; found: 235.3. The spectral data were in accordance with those reported in the literature. ${ }^{20}$

1q was prepared according to the following sequence:

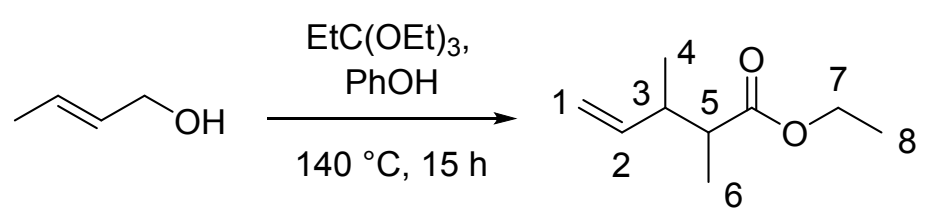

1q, $91 \%$

1: 1.3

\section{Ethyl 2,3-dimethylpent-4-enoate (1q)}

General procedure A to yield the title compound as an inseperable mixture of diastereoisomers $(1: 1.3$, $2.125 \mathrm{~g}, 13.6 \mathrm{mmol}, 91 \%)$ as a colourless oil from crotyl alcohol $(1.3 \mathrm{~mL}, 15 \mathrm{mmol})$ and triethyl orthopropionate. Purification was achieved by column chromatography on silica gel using 5\% EtOAc/Hexane (v/v). Indistinguishable mixture of isomers $\boldsymbol{\delta}_{\mathbf{H}}\left(400 \mathrm{MHz}, \mathrm{CDCl}_{3}\right): 5.82-5.51(\mathrm{~m}, 2 \mathrm{H}$, H-2), 5.04-4.92 (m, 4H, H-1), 4.16-4.05 (m, 4H, H-7), 2.51-2.22 (m, 4H, H-3, H-5), 1.25-1.20 (m, 6H, H-8), 1.10-1.05 (m, 6H, H-6), 1.02-0.96 (m, 6H, H-4). LRMS: $\left(\mathrm{ESI}^{+}\right) \mathrm{m} / \mathrm{z}$ calcd for $\mathrm{C}_{9} \mathrm{H}_{17} \mathrm{O}_{2}$ $\left([\mathrm{M}+\mathrm{H}]^{+}\right)$: 157.1; found: 157.1. The spectral data were in accordance with those reported in the literature. ${ }^{21}$

1r was prepared according to the following sequence:

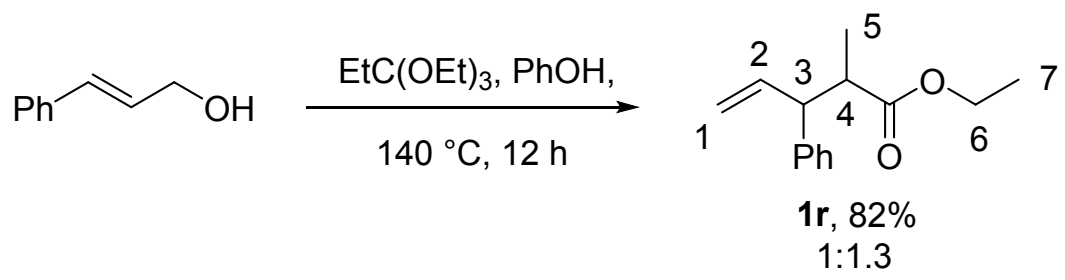

Ethyl 2-methyl-3-phenylpent-4-enoate (1r) 
General procedure A to yield the title compound as an inseperable mixture of diasteroisomers $(1: 1.3$, $3.31 \mathrm{~g}, 15.2 \mathrm{mmol}, 82 \%)$ as a colourless oil from cinnamyl alcohol (2.5 g, $18.5 \mathrm{mmol})$ and triethyl orthopropionate. Purification was achieved by column chromatography on silica gel using 3\% EtOAc/Hexane (v/v). Indistinguishable mixture of isomers $\boldsymbol{\delta}_{\mathbf{H}}\left(400 \mathrm{MHz}, \mathrm{CDCl}_{3}\right): 7.35-7.14(\mathrm{~m}, 10 \mathrm{H}$, Ar-H), 6.06-5.86 (m, 2H, H-2), 5.16-4.98 (m, 4H, H-1), 4.14 (q, J6-7 $=6.9$ Hz, 2H, H-6), 3.88 (q, J6-7 = $7.1 \mathrm{~Hz}, 2 \mathrm{H}, \mathrm{H}-6$ ), 3.51-3.40 (m, 2H, H-3), 2.85-2.75 (m, 2H, H-4), 1.28-1.20 (m, 6H, H-6), 0.99-0.94 (m, 6H, H-5). LRMS: $\left(\mathrm{ESI}^{+}\right) \mathrm{m} / \mathrm{z}$ calcd for $\mathrm{C}_{14} \mathrm{H}_{19} \mathrm{O}_{2}\left([\mathrm{M}+\mathrm{H}]^{+}\right)$: 219.1; found: 219.1. The spectral data were in accordance with those reported in the literature. ${ }^{22}$

1s was prepared according to the following sequence:

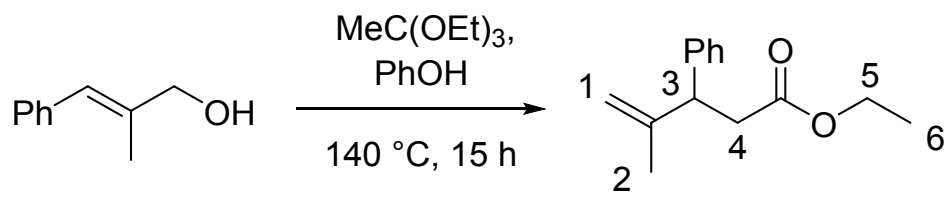

$1 \mathrm{~s}, 84 \%$

\section{Ethyl 4-methyl-3-phenylpent-4-enoate (1s)}

General procedure A to yield the title compound $(1.83 \mathrm{~g}, 8.39 \mathrm{mmol}, 84 \%)$ as a colourless oil from triethyl orthoacetate. Purification was achieved by column chromatography on silica gel using 3\% EtOAc/Hexane (v/v). $\boldsymbol{\delta}_{\mathbf{H}}\left(400 \mathrm{MHz}, \mathrm{CDCl}_{3}\right)$ : 7.31-7.18 (m, 5H, Ar-H), 4.91 (s, 1H, H-1), 4.88 (s, 1H, H-1'), 4.06 (q, $\left.J_{6-5}=7.1 \mathrm{~Hz}, 2 \mathrm{H}, \mathrm{H}-5\right), 3.79$ (t, $\left.J_{3-4}=7.9 \mathrm{~Hz}, 1 \mathrm{H}, \mathrm{H}-3\right), 2.84$ (dd, $J_{4-4}=14.6 \mathrm{~Hz}, J_{4-3}=$ $7.9 \mathrm{~Hz}, 1 \mathrm{H}, \mathrm{H}-4), 2.70$ (dd, $J_{4^{\prime}-4}=14.6 \mathrm{~Hz}, J_{4-3}=7.9 \mathrm{~Hz}, 1 \mathrm{H}, \mathrm{H}-4$ '), 1.62 (s, 3H, H-2), 1.16 (t, $J_{6-5}=7.1$ $\mathrm{Hz}, 3 \mathrm{H}, \mathrm{H}-6)$. LRMS: $\left(\mathrm{ESI}^{+}\right) \mathrm{m} / \mathrm{z}$ calcd for $\mathrm{C}_{14} \mathrm{H}_{19} \mathrm{O}_{2}\left([\mathrm{M}+\mathrm{H}]^{+}\right): 219.1$; found: 219.1. The spectral data were in accordance with those reported in the literature. ${ }^{23}$

1t was prepared according to the following sequence:<smiles>CCOC(=O)CCC(C)=O</smiles>

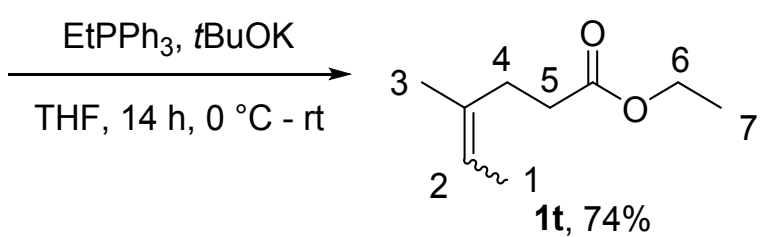

\section{Ethyl 4-methylpent-4-enoate (1t)}

To a solution of ethyltriphenylphosphonium bromide ( $3.12 \mathrm{~g}, 8.4 \mathrm{mmol}, 1.20$ equiv.) in anhydrous THF $(14 \mathrm{~mL})$ under an atmosphere of argon at $0{ }^{\circ} \mathrm{C}$ was added $1 \mathrm{M} t \mathrm{BuOK}(9.1 \mathrm{~mL}, 9.1 \mathrm{mmol}, 1.3$ equiv.) and the mixture was stirred for $30 \mathrm{~min}$. Ethyl levulinate $(0.99 \mathrm{~mL}, 7.0 \mathrm{mmol}, 1.0$ equiv.) was then added, 
and after 30 mins the reaction mixture was allowed to warm to rt, and was stirred for a further $14 \mathrm{~h}$. The reaction was diluted $\mathrm{CH}_{2} \mathrm{Cl}_{2}(50 \mathrm{~mL})$ and quenched with $2 \mathrm{M}$ aqueous $\mathrm{HCl}(10 \mathrm{~mL})$. After phase separation, the aqueous phase was extracted further with $\mathrm{CH}_{2} \mathrm{Cl}_{2}(2 \times 25 \mathrm{~mL})$. The combined organic layers were then washed with brine, dried over $\mathrm{MgSO}_{4}$, filtered and the solvent removed in vacuo. Purification was achieved using 10\% EtOAc/Hexane (v/v) to afford the title compound as a colourless oil as a mixture of stereoisomers ( $787 \mathrm{mg}, 5.18 \mathrm{mmol}, 74 \%$ ( $\mathrm{dr}$ could not be obtained due to overlapping NMR peaks)). $\boldsymbol{\delta}_{\mathbf{H}}\left(400 \mathrm{MHz}, \mathrm{CDCl}_{3}\right): 5.25$ (s, 1H, H-2), 4.17-4.07 (m, 2H, H-6), 2.42-2.24 (m, 4H, H-4, H-5), 1.70-1.52 (m, 6H, H-1, H-3), 1.30-1.19 (m, 3H, H-7). LRMS: (ESI-) $m / z$ calcd for $\mathrm{C}_{9} \mathrm{H}_{15} \mathrm{O}_{2}$ ([M-H] $]^{-}$: 155.1; found: 155.1. The spectral data were in accordance with those reported in the literature. ${ }^{24}$

$1 \mathbf{u}$ was prepared according to the following sequence:

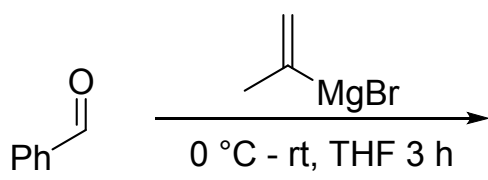

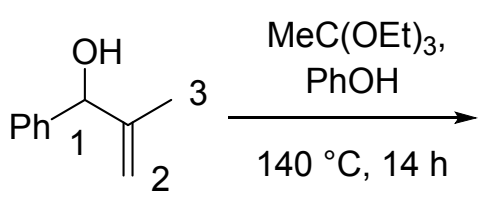

$13,94 \%$

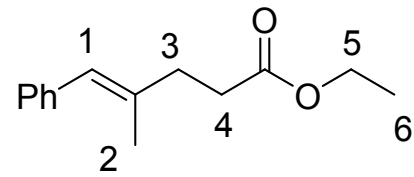

$1 \mathrm{u}, 87 \%$

\section{2-Methyl-1-phenylprop-2-en-1-ol (13)}

To a solution of benzaldehyde $(0.66 \mathrm{~mL}, 6.5 \mathrm{mmol}, 1.0$ equiv.) in anhydrous THF $(10 \mathrm{~mL})$ under an atmosphere of argon at $0{ }^{\circ} \mathrm{C}$ was added $0.5 \mathrm{M}$ isopropenymagnesium bromide solution in THF (14.3 $\mathrm{mL}, 7.15 \mathrm{mmol}, 1.1$ equiv.). The reaction was stirred at this temperature for $30 \mathrm{~min}$ and then allowed to react at $\mathrm{rt}$ for $3 \mathrm{~h}$. The solution was diluted with $\mathrm{Et}_{2} \mathrm{O}(150 \mathrm{~mL})$, poured into a separating funnel and quenched with a saturated aqueous solution of $\mathrm{NH}_{4} \mathrm{Cl}(60 \mathrm{~mL})$. After phase separation, the aqueous phase was extracted with $\mathrm{Et}_{2} \mathrm{O}(3 \times 50 \mathrm{~mL})$. The combined organic layers were washed with brine (70 $\mathrm{mL}$ ), dried over $\mathrm{MgSO}_{4}$ and the solvent removed in vacuo to yield the title compound as a colourless oil (902 $\mathrm{mg}, 6.10 \mathrm{mmol}, 94 \%)$ without the requirement for further purification. $\boldsymbol{\delta}_{\mathbf{H}}\left(400 \mathrm{MHz}, \mathrm{CDCl}_{3}\right)$ : 7.39-7.25 (m, 5H, Ar-H), 5.29 (s, 1H, H-2), 5.13 (d, $J_{1-O H}=3.3$ Hz, 1H, H-1), 4.94 (s, 1H, H-2'), 1.92 $\left(\mathrm{d}, J_{\mathrm{OH}-\mathrm{l}}=3.3 \mathrm{~Hz}, 1 \mathrm{H}, \mathrm{OH}\right), 1.60(\mathrm{~s}, 3 \mathrm{H}, \mathrm{H}-3)$. LRMS: $\left(\mathrm{ESI}^{+}\right) \mathrm{m} / \mathrm{z}$ calcd for $\mathrm{C}_{10} \mathrm{H}_{12} \mathrm{ONa}\left([\mathrm{M}+\mathrm{Na}]^{+}\right)$: 171.1; found: 171.1. The spectral data were in accordance with those reported in the literature. ${ }^{25}$

\section{Ethyl (E)-4-methyl-5-phenylpent-4-enoate (1u)}

General procedure A to yield the title compound (1.26 g, $5.77 \mathrm{mmol}, 87 \%)$ as a colourless oil from 13 ( $880 \mathrm{mg}, 5.0 \mathrm{mmol})$ and triethyl orthoacetate. Purification was achieved by column chromatography on silica gel using 4\% EtOAc/Hexane (v/v). $\boldsymbol{\delta}_{\mathbf{H}}\left(400 \mathrm{MHz}, \mathrm{CDCl}_{3}\right)$ : 7.35-7.27 (m, 3H, Ar-H), 7.22-7.16 
(m, 2H, Ar-H), 6.28 (s, 1H, H-1), 4.13 (q, $\left.J_{5-6}=7.1 \mathrm{~Hz}, 2 \mathrm{H}, \mathrm{H}-5\right), 2.56-2.45$ (m, 4H, H-3, H-4), 1.85 (s, 3H, H-2), 1.25 (t, $\left.J_{6-5}=7.1 \mathrm{~Hz}, 3 \mathrm{H}, \mathrm{H}-6\right)$. LRMS: $\left(\mathrm{ESI}^{+}\right) \mathrm{m} / \mathrm{z}$ calcd for $\mathrm{C}_{14} \mathrm{H}_{18} \mathrm{O}_{2} \mathrm{Na}\left([\mathrm{M}+\mathrm{Na}]^{+}\right)$: 241.1; found: 241.1. The spectral data were in accordance with those reported in the literature. ${ }^{26}$

$1 \mathbf{v}$ was prepared according to the following sequence:<smiles>C=C(C)C(=O)CCC(C)P(C)c1ccccc1</smiles>

$14,88 \%$

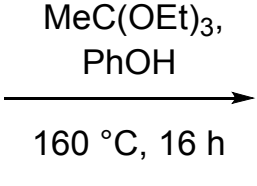

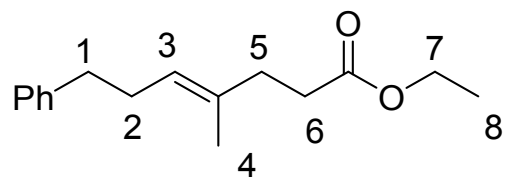

$1 v, 88 \%$

\section{2-Methyl-5-phenylpent-1-en-3-ol (14)}

To a solution of hydrocinnamaldehyde $(1.3 \mathrm{~mL}, 10.0 \mathrm{mmol}, 1.0$ equiv. $)$ in anhydrous THF $(10 \mathrm{~mL})$ under an atmosphere of argon at $0{ }^{\circ} \mathrm{C}$ was added $0.5 \mathrm{M}$ isopropenymagnesium bromide solution in THF (21 mL, $10.5 \mathrm{mmol}, 1.05$ equiv.). The reaction was stirred at this temperature for $30 \mathrm{~min}$ and then allowed to react at $\mathrm{rt}$ for $3 \mathrm{~h}$. The solution was diluted with $\mathrm{Et}_{2} \mathrm{O}(150 \mathrm{~mL})$, poured into a separating funnel and quenched with a saturated aqueous solution of $\mathrm{NH}_{4} \mathrm{Cl}(60 \mathrm{~mL})$. After phase separation, the aqueous phase was extracted with $\mathrm{Et}_{2} \mathrm{O}(3 \times 50 \mathrm{~mL})$. The combined organic layers were washed with brine $\left(70 \mathrm{~mL}\right.$ ), dried over $\mathrm{MgSO}_{4}$ and the solvent removed in vacuo. Purification was achieved by column chromatography on silica gel using $5 \rightarrow 10 \%$ EtOAc/Hexane $(\mathrm{v} / \mathrm{v})$ to furnish the product as a colourless oil (1.545 g, $8.78 \mathrm{mmol}, 88 \%)$. $\boldsymbol{\delta}_{\mathbf{H}}\left(400 \mathrm{MHz}, \mathrm{CDCl}_{3}\right): 7.33-7.15(\mathrm{~m}, 5 \mathrm{H}, \mathrm{Ar}-\mathrm{H}), 4.97(\mathrm{~s}, 1 \mathrm{H}$, H-4), 4.87 (s, 1H, H-4'), 4.12-4.06 (m, 1H, H-3), 2.79-2.58 (m, 2H, H-1), 1.93-1.83 (m, 2H, H-2), 1.75 (s, 3H, H-5). LRMS: (ESI-) $\mathrm{m} / \mathrm{z}$ calcd for $\mathrm{C}_{12} \mathrm{H}_{16} \mathrm{OBr}\left([\mathrm{M}+\mathrm{Br}]^{-}\right)$: 255.0; found: 255.0. The spectral data were in accordance with those reported in the literature. ${ }^{27}$

\section{Ethyl (E)-4-methyl-7-phenylhept-4-enoate (1v)}

General procedure A to yield the title compound $(1.08 \mathrm{~g}, 4.41 \mathrm{mmol}, 88 \%)$ as a colourless oil from 14 $(880 \mathrm{mg}, 5.0 \mathrm{mmol})$ and triethyl orthoacetate. Purification was achieved by column chromatography on silica gel using 5\% EtOAc/Hexane (v/v). $\boldsymbol{\delta}_{\mathbf{H}}\left(400 \mathrm{MHz}, \mathrm{CDCl}_{3}\right): 7.31-7.12(\mathrm{~m}, 5 \mathrm{H}, \mathrm{Ar}-\mathrm{H}), 5.21\left(\mathrm{t}, J_{3-2}\right.$ $=7.2 \mathrm{~Hz}, 1 \mathrm{H}, \mathrm{H}-3), 4.11\left(\mathrm{q}, J_{7-8}=7.2 \mathrm{~Hz}, 2 \mathrm{H}, \mathrm{H}-7\right), 2.62\left(\mathrm{t}, J_{l-2}=7.7 \mathrm{~Hz}, 2 \mathrm{H}, \mathrm{H}-1\right), 2.42-2.25(\mathrm{~m}, 6 \mathrm{H}$, H-2, H-5, H-6), 1.55 (s, 3H, H-4), 1.25 (t, $\left.J_{8-7}=7.2 \mathrm{~Hz}, 3 \mathrm{H}, \mathrm{H}-8\right)$. LRMS: (ESI ${ }^{+}$) m/z calcd for $\mathrm{C}_{16} \mathrm{H}_{22} \mathrm{O}_{2} \mathrm{Na}\left([\mathrm{M}+\mathrm{Na}]^{+}\right): 269.2$; found: 269.12 . The spectral data were in accordance with those reported in the literature. ${ }^{28}$ 
1w was prepared according to the following sequence:
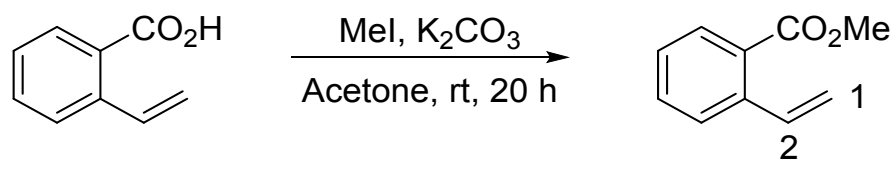

$1 w, 93 \%$

\section{Methyl 2-vinylbenzoate (1w)}

To a solution of 2-vinylbenzoic acid (370 mg, $2.5 \mathrm{mmol}, 1.0$ equiv.) in acetone (25 mL), was added anhydrous $\mathrm{K}_{2} \mathrm{CO}_{3}(590 \mathrm{mg}, 5.0 \mathrm{mmol}, 2.0$ equiv.) and the reaction was stirred vigourously for 5 mins. MeI ( $0.23 \mathrm{~mL}, 3.75 \mathrm{mmol}, 1.5$ equiv. ) was added and the reaction was stirred for $20 \mathrm{~h}$. The solvent was removed in vacuo and the residue was redissolved in $\mathrm{CH}_{2} \mathrm{Cl}_{2}(30 \mathrm{~mL})$, washed with water $(10 \mathrm{~mL})$, dried over $\mathrm{MgSO}_{4}$, filtered, and the solvent removed in vacuo to yield the title compound as a colourless oil (376 mg, $2.32 \mathrm{mmol}, 93 \%)$ without further purification being required. $\boldsymbol{\delta}_{\mathbf{H}}\left(400 \mathrm{MHz}, \mathrm{CDCl}_{3}\right): 7.86$ $\left(\mathrm{d}, J_{A r H-A r H}=7.9 \mathrm{~Hz}, 1 \mathrm{H}, \mathrm{Ar}-\mathrm{H}\right), 7.57\left(\mathrm{~d}, J_{A r H-A r H}=7.8 \mathrm{~Hz}, 1 \mathrm{H}, \mathrm{Ar}-\mathrm{H}\right), 7.50-7.40(\mathrm{~m}, 2 \mathrm{H}, \mathrm{H}-2, \mathrm{Ar}-\mathrm{H})$, 7.30 (app-t, $1 \mathrm{H}, \mathrm{Ar}-\mathrm{H}), 5.64$ (dd, $\left.J_{l-2}=17.3 \mathrm{~Hz}, J_{l^{-1}}=1.3 \mathrm{~Hz}, 1 \mathrm{H}, \mathrm{H}-1\right), 5.34$ (dd, $J_{l^{\prime}-2}=11.2 \mathrm{~Hz}, J_{l^{\prime}-1}$ $=1.3 \mathrm{~Hz}, 1 \mathrm{H}, \mathrm{H}-1), 3.89$ (s, $3 \mathrm{H}, \mathrm{CO}_{2} \mathrm{Me}$ ). LRMS: (ESI-) $\mathrm{m} / z$ calcd for $\mathrm{C}_{10} \mathrm{H}_{9} \mathrm{O}_{2}\left([\mathrm{M}-\mathrm{H}]^{-}\right): 161.1$; found: 161.2. The spectral data were in accordance with those reported in the literature. ${ }^{29}$

$\mathbf{1} \mathbf{x}$ was prepared according to the following sequence:
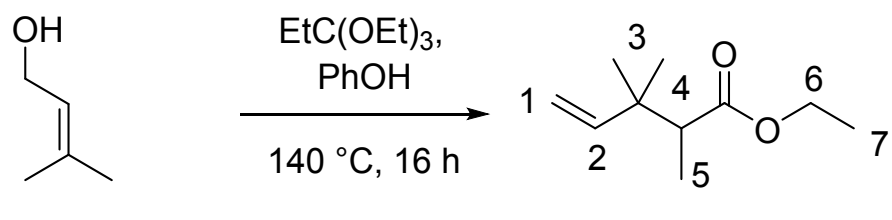

$$
1 \mathrm{x}, 84 \%
$$

\section{Ethyl 2,3,3-trimethylpent-4-enoate (1x)}

General procedure A to yield the title compound $(1.54 \mathrm{~g}, 8.39 \mathrm{mmol}, 84 \%)$ as a colourless oil from prenol and triethyl orthopropionate. Purification was achieved by column chromatography on silica gel using $1.5 \rightarrow 3.0 \%$ EtOAc/Hexane (v/v). $\boldsymbol{\delta}_{\mathbf{H}}\left(400 \mathrm{MHz}, \mathrm{CDCl}_{3}\right): 5.85\left(\mathrm{dd}, J_{2-1}=18.0 \mathrm{~Hz}, J_{2-1}=11.0 \mathrm{~Hz}\right.$, 1H, H-2), 5.00-4.92 (m, 2H, H-1), 4.11 (q, $J_{6-7}=7.1 \mathrm{~Hz}, 2 \mathrm{H}, \mathrm{H}-7$ ), 2.35 (q, $\left.J_{4-5}=7.2 \mathrm{~Hz}, 1 \mathrm{H}, \mathrm{H}-4\right), 1.25$ (t, $\left.J_{7-6}=7.1 \mathrm{~Hz}, 3 \mathrm{H}, \mathrm{H}-7\right), 1.08-1.04(\mathrm{~m}, 9 \mathrm{H}, \mathrm{H}-4, \mathrm{H}-6)$. LRMS: $\left(\mathrm{ESI}^{+}\right) \mathrm{m} / \mathrm{z}$ calcd for $\mathrm{C}_{10} \mathrm{H}_{19} \mathrm{O}_{2}$ $\left([\mathrm{M}+\mathrm{H}]^{+}\right)$: 171.1; found: 171.1. The spectral data were in accordance with those reported in the literature. ${ }^{30}$

1y was prepared according to the following sequence: 


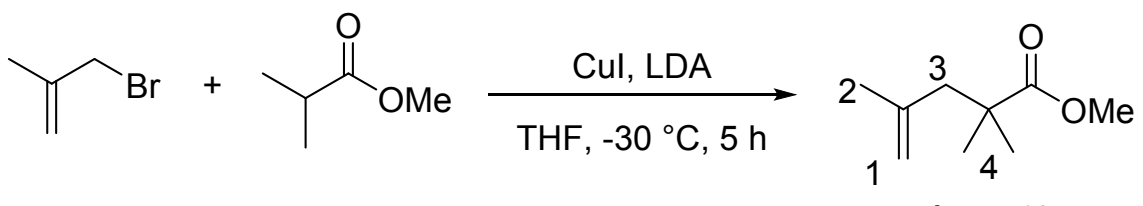

$1 \mathbf{y}, 74 \%$

\section{Methyl 2,2,4-trimethylpent-4-enoate (1y)}

To a solution of methyl isobutyrate $(0.55 \mathrm{~mL}, 4.80 \mathrm{mmol}, 1.5$ equiv.) and CuI (914 mg, $4.8 \mathrm{mmol}, 1.5$ equiv.) in anhydrous THF $(10 \mathrm{~mL})$, under an atmosphere of argon at $-78{ }^{\circ} \mathrm{C}$ was added $2.0 \mathrm{M}$ LDA solution in hexane $(2.56 \mathrm{~mL}, 5.12 \mathrm{mmol} 1.6$ equiv.). The mixture was stirred for $30 \mathrm{~min}$ and 3-bromo2-methylpropene ( $0.32 \mathrm{~mL}, 3.20 \mathrm{mmol}, 1.0$ equiv. $)$ in anhydrous THF ( $2 \mathrm{~mL})$, under argon, was added and the mixture stirred at this temperature for $1 \mathrm{~h}$ before being warmed to $-30{ }^{\circ} \mathrm{C}$. After a further $5 \mathrm{~h}$ the reaction mixture was allowed to warm to $\mathrm{rt}$ and was then poured into a separating funnel, diluted with $\mathrm{CH}_{2} \mathrm{Cl}_{2}(60 \mathrm{~mL})$, and quenched with saturated aqueous solution of $\mathrm{NaHCO}_{3}(30 \mathrm{~mL})$. After phase separation, the aqueous phase was washed twice with $\mathrm{CH}_{2} \mathrm{Cl}_{2}(2 \times 25 \mathrm{~mL})$. The combined organic phases were washed with water, then brine, dried over $\mathrm{MgSO}_{4}$, filtered, and the solvent evaporated in vacuo. Purification of the crude product was achieved by column chromatography on silica gel using $10 \%$ EtOAc/Hexane (v/v) to yield the title compound as a colourless oil $(551 \mathrm{mg}, 3.53 \mathrm{mmol}, 74 \%)$. $\boldsymbol{\delta}_{\mathbf{H}}\left(400 \mathrm{MHz}, \mathrm{CDCl}_{3}\right): 4.80$ (s, 1H, H-1), 4.64 (s, 1H, H-1'), 3.66 (s, 3H, OMe), 2.30 (s, 2H, H-3), 1.65 (s, 3H, H-2), 1.18 (s, 6H, H-4). LRMS: $\left(\mathrm{ESI}^{+}\right) \mathrm{m} / z$ calcd for $\mathrm{C}_{9} \mathrm{H}_{17} \mathrm{O}_{2}\left([\mathrm{M}+\mathrm{H}]^{+}\right)$: 157.1; found: 157.1 . The spectral data were in accordance with those reported in the literature. ${ }^{31}$ 


\section{Intermolecular Acyl-Thiol-Ene Reaction}

Thioester $\mathbf{2 a - 2 y}$ were prepared according to the following sequence:<smiles>[R]C=C([R2])C([R])([R])C([R])([R])C(=O)OCC</smiles><smiles>CC(=O)S</smiles><smiles>CCOC(=O)OCC</smiles><smiles>[R]C(SC)C([R])C([R])([R])C([R])([R])C(=O)OCC</smiles>

Ethyl 5-(acetylthio)pentanoate (2a)

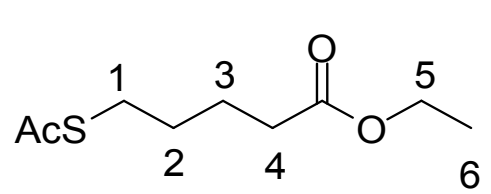

General procedure B to yield the title compound (479 mg, $2.35 \mathrm{mmol}$, $94 \%)$ as a colourless wax from ethyl 4-pentenoate $(320 \mathrm{mg}, 2.50$ mmol). Purification was achieved by column chromatography on silica gel using $3 \rightarrow 7 \%$ EtOAc/Hexane $(\mathrm{v} / \mathrm{v}) . \quad \mathbf{R}_{\mathbf{f}}=0.22(10 \%$ EtOAc/Hexane (v/v)). $\boldsymbol{\delta}_{\mathbf{H}}\left(400 \mathrm{MHz}, \mathrm{CDCl}_{3}\right): 4.12$ (q, $\left.J_{5-6}=7.2 \mathrm{~Hz}, 2 \mathrm{H}, \mathrm{H}-5\right), 2.87$ (t, $J_{1-2}=7.1 \mathrm{~Hz}, 2 \mathrm{H}$, H-1), 2.33-2.28 (m, 5H, H-4, SAc), 1.74-1.65 (m, 2H, H-2), 1.65-1.56 (m, 2H, H-3), 1.25 (t, $J_{6-5}=7.2$ $\mathrm{Hz}, 2 \mathrm{H}, \mathrm{H}-6) . \boldsymbol{\delta}_{\mathbf{C}}\left(101 \mathrm{MHz}, \mathrm{CDCl}_{3}\right): 195.8(\mathrm{C}=\mathrm{O}), 173.3$ (C=O), 60.3 (C-5), 33.7 (C-4), $30.6\left(\mathrm{CH}_{3}\right)$, 29.0 (C-1), 28.7 (C-2), 24.0 (C-3), 14.2 (C-6). $\mathbf{v}_{\max }$ (ATR)/ $\mathrm{cm}^{-1}: 767$ (C-S), 1161 (C-O), 1673 (C=O), $1712(\mathrm{C}=\mathrm{O}), 2982(\mathrm{C}-\mathrm{H})$. LRMS: $\left(\mathrm{ESI}^{+}\right) \mathrm{m} / \mathrm{z}$ calcd for $\mathrm{C}_{9} \mathrm{H}_{16} \mathrm{O}_{3} \mathrm{~S}\left([\mathrm{M}+\mathrm{H}]^{+}\right)$: 205.1; found: 205.1 .

Ethyl 5-(acetylthio)-2-methylpentanoate (2b)<smiles>CCOC(=O)[C@H](C)CCOC(=O)O</smiles>

General procedure B to yield the title compound (608 mg, $2.79 \mathrm{mmol}, 93 \%)$ as a colourless wax from ethyl 2-methyl-4-pentenoate $(0.49 \mathrm{~mL}, 3.00 \mathrm{mmol})$. Purification was achieved by column chromatography on silica gel using $3 \rightarrow 5 \%$ EtOAc/Hexane (v/v). $\mathbf{R}_{\mathbf{f}}=0.22(10 \%$ EtOAc/Hexane $(\mathrm{v} / \mathrm{v})) . \boldsymbol{\delta}_{\mathbf{H}}(400$ $\left.\mathrm{MHz}, \mathrm{CDCl}_{3}\right): 4.15$ (q, $\left.J_{6-7}=7.1 \mathrm{~Hz}, 2 \mathrm{H}, \mathrm{H}-6\right), 2.88$ (t, $J_{l-2}=7.2 \mathrm{~Hz}, 2 \mathrm{H}, \mathrm{H}-$ 1), 2.44 (app-h, 1H, H-4), 2.35 (s, 3H, SAc), 1.79-1.69 (m, 1H, H-2), 1.66-1.45 (m, 3H, H-2', H-3), $1.27\left(\mathrm{t}, J_{7-6}=7.1 \mathrm{~Hz}, 3 \mathrm{H}, \mathrm{H}-7\right), 1.17\left(\mathrm{~d}, J_{5-4}=7.1 \mathrm{~Hz}, 3 \mathrm{H}, \mathrm{H}-5\right) . \boldsymbol{\delta}_{\mathrm{C}}\left(101 \mathrm{MHz}, \mathrm{CDCl}_{3}\right): 195.9(\mathrm{C}=\mathrm{O})$, $176.4(\mathrm{C}=\mathrm{O}), 60.3(\mathrm{C}-6), 39.1(\mathrm{C}-4), 32.7(\mathrm{C}-2), 30.6\left(\mathrm{CH}_{3}\right), 28.9(\mathrm{C}-1), 27.3$ (C-3), 17.1 (C-5), 14.3 (C-7). $v_{\max }(\mathrm{ATR}) / \mathrm{cm}^{-1}: 737(\mathrm{C}-\mathrm{S}), 1135(\mathrm{C}-\mathrm{O}), 1692(\mathrm{C}=\mathrm{O}), 1730(\mathrm{C}=\mathrm{O}), 2977(\mathrm{C}-\mathrm{H}) . \mathbf{H R M S}:\left(\mathrm{ESI}^{+}\right)$ $m / z$ calcd for $\mathrm{C}_{10} \mathrm{H}_{18} \mathrm{O}_{3} \mathrm{SNa}\left([\mathrm{M}+\mathrm{Na}]^{+}\right)$: 241.0874; found: 241.0866 .

\section{Ethyl 5-(acetylthio)-3-phenylpentanoate (2c)}

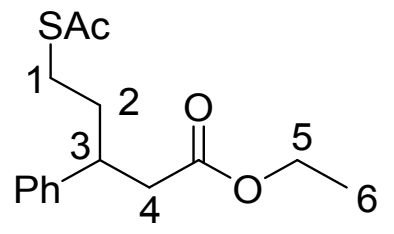

General procedure B to yield the title compound (395 mg, $1.41 \mathrm{mmol}, 91 \%$ ) as a colourless wax from 1c (318 $\mathrm{mg}, 1.55 \mathrm{mmol})$. Purification was achieved by column chromatography on silica gel using $3 \rightarrow 6 \%$ EtOAc/Hexane (v/v). $\mathbf{R}_{\mathbf{f}}=0.15(10 \%$ EtOAc/Hexane $(\mathrm{v} / \mathrm{v}))$. $\boldsymbol{\delta}_{\mathbf{H}}\left(400 \mathrm{MHz}, \mathrm{CDCl}_{3}\right): 7.33-7.27(\mathrm{~m}$, 2H, Ar-H), 7.24-7.17 (m, 3H, Ar-H), 4.03 (q, $\left.J_{5-6}=7.1 \mathrm{~Hz}, 2 \mathrm{H}, \mathrm{H}-5\right), 3.19$ 
(app-p, 1H, H-3), 2.79-2.70 (m, 1H, H-1), 2.69-2.59 (m, 3H, H-1', H-4), 2.32 (s, 3H, SAc), 2.01-1.87 (m, 2H, H-2), 1.16 (t, $\left.J_{6-5}=7.1 \mathrm{~Hz}, 2 \mathrm{H}, \mathrm{H}-6\right) . \boldsymbol{\delta}_{\mathbf{C}}\left(101 \mathrm{MHz}, \mathrm{CDCl}_{3}\right): 195.7(\mathrm{C}=\mathrm{O}), 171.9(\mathrm{C}=\mathrm{O}), 142.5$ (q, Ar-C), 128.6, 127.6, 126.9 (Ar-C), 60.4 (C-5), 41.6 (C-4), 41.5 (C-3), 35.6 (C-2), $30.6\left(\mathrm{CH}_{3}\right), 27.1$ (C-1), 14.1 (C-6). $v_{\max }$ (ATR)/cm- $1: 690$ (ArC-H bend), 750 (C-S), 1048 (C-O), 1690 (C=O), 1735 $(\mathrm{C}=\mathrm{O}), 2982(\mathrm{C}-\mathrm{H})$. HRMS: $\left(\mathrm{APCI}^{+}\right) \mathrm{m} / z$ calcd for $\mathrm{C}_{15} \mathrm{H}_{21} \mathrm{O}_{3} \mathrm{~S}\left([\mathrm{M}+\mathrm{H}]^{+}\right)$: 281.1206; found: 281.1214.

\section{Ethyl 5-(acetylthio)-3-phenethylpentanoate (2d)}

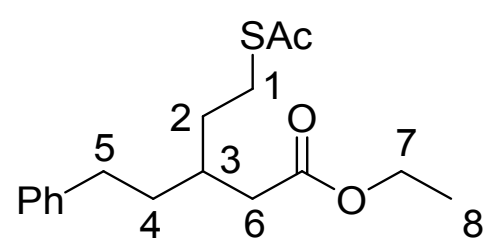

General procedure B to yield the title compound $(555 \mathrm{mg}, 1.80 \mathrm{mmol}$, 94\%) as a colourless wax from 1d (446 mg, $1.92 \mathrm{mmol})$. Purification was achieved by column chromatography on silica gel using $2.5 \rightarrow 6.0 \%$ EtOAc/Hexane $(\mathrm{v} / \mathrm{v}) . \mathbf{R}_{\mathbf{f}}=0.17(10 \%$ EtOAc/Hexane $(\mathrm{v} / \mathrm{v})) . \boldsymbol{\delta}_{\mathbf{H}}\left(400 \mathrm{MHz}, \mathrm{CDCl}_{3}\right): 7.33-7.27(\mathrm{~m}, 2 \mathrm{H}, \mathrm{Ar}-\mathrm{H}), 7.23-7.16$ (m, 3H, Ar-H), 4.16 (q, $\left.J_{7-8}=7.1 \mathrm{~Hz}, 2 \mathrm{H}, \mathrm{H}-7\right), 2.91$ (t, $\left.J_{1-2}=7.9 \mathrm{~Hz}, 2 \mathrm{H}, \mathrm{H}-1\right), 2.65$ (t, $J_{5-4}=8.3 \mathrm{~Hz}$, 2H, H-5), 2.37 (t, $\left.J_{6-3}=6.6 \mathrm{~Hz}, 2 \mathrm{H}, \mathrm{H}-6\right), 2.35$ (s, 3H, SAc), 2.09-1.99 (m, 1H, H-3), 1.76-1.62 (m, 4H, H-2, H-4), 1.28 (t, $\left.J_{8-7}=7.1 \mathrm{~Hz}, 3 \mathrm{H}, \mathrm{H}-8\right)$. $\boldsymbol{\delta}_{\mathbf{C}}\left(101 \mathrm{MHz}, \mathrm{CDCl}_{3}\right): 195.6,172.8(\mathrm{C}=\mathrm{O}), 142.1$ (q, Ar-C), 128.4, 128.3, 125.8 (Ar-C), 60.4 (C-7), 38.6 (C-6), 35.5 (C-2), 34.3 (C-3), 33.6 (C-4), 32.8 (C5), $30.6\left(\mathrm{CH}_{3}\right), 26.5(\mathrm{C}-1), 14.2(\mathrm{C}-8) . v_{\max }(\mathrm{ATR}) / \mathrm{cm}^{-1}: 674$ (C-H bend), 735 (C-S), 1049 (C-O), 1691 $(\mathrm{C}=\mathrm{O}), 1732(\mathrm{C}=\mathrm{O}), 2935(\mathrm{C}-\mathrm{H})$. HRMS: $\left(\mathrm{APCI}^{+}\right) \mathrm{m} / z$ calcd for $\mathrm{C}_{17} \mathrm{H}_{25} \mathrm{O}_{3} \mathrm{~S}\left([\mathrm{M}+\mathrm{H}]^{+}\right): 309.1524$; found: 309.1514 .

\section{Ethyl 5-(acetylthio)-3-(4-fluorophenyl)pentanoate (2e)}<smiles>COC(=O)OC(=O)CCCC(C)(C)C</smiles>

General procedure B to yield the title compound $(311 \mathrm{mg}, 1.04$ mmol, $87 \%$ (yield determined by combination of ${ }^{1} \mathrm{H}$ NMR ratio and isolated yield due to MAP contaminant)) as a colourless wax from 1e (269 mg, $1.20 \mathrm{mmol})$. Purification was achieved by column chromatography on silica gel using $3 \rightarrow 8 \%$ EtOAc/Hexane (v/v). $\mathbf{R}_{\mathbf{f}}$ $=0.16(10 \%$ EtOAc/Hexane $(\mathrm{v} / \mathrm{v})) . \boldsymbol{\delta}_{\mathbf{H}}\left(400 \mathrm{MHz}, \mathrm{CDCl}_{3}\right): 7.22-7.15(\mathrm{~m}, 2 \mathrm{H}, \mathrm{Ar}-\mathrm{H}), 7.05-6.98(\mathrm{~m}$, 2H, Ar-H), 4.05 (q, $\left.J_{5-6}=7.1 \mathrm{~Hz}, 2 \mathrm{H}, \mathrm{H}-5\right), 3.25-3.17$ (m, 1H, H-3), 2.81-2.72 (m, 1H, H-1), 2.67-2.52 (m, 3H, H-1', H-4), 2.33 (s, 3H, SAc), 1.99-1.82 (m, 2H, H-2), 1.16 (t, $\left.J_{6-5}=7.1 \mathrm{~Hz}, 2 \mathrm{H}, \mathrm{H}-6\right) . \boldsymbol{\delta}_{\mathbf{C}}(101$ $\left.\mathrm{MHz}, \mathrm{CDCl}_{3}\right)$ : $195.6(\mathrm{C}=\mathrm{O}), 171.7(\mathrm{C}=\mathrm{O}), 161.8\left(\mathrm{~d}, J_{C-F}=245.5 \mathrm{~Hz}, \mathrm{Ar}-\mathrm{CF}\right), 138.1\left(\mathrm{~d}, J_{C-F}=3.3 \mathrm{~Hz}\right.$, q, Ar-C), 129.0 (d, $\left.J_{C-F}=7.9 \mathrm{~Hz}, \mathrm{Ar}-\mathrm{C}\right), 115.5$ (d, $\left.J_{C-F}=21.3 \mathrm{~Hz}, \mathrm{Ar}-\mathrm{CF}\right), 60.4$ (C-5), 41.7 (C-4), 40.8 (C-3), 35.7 (C-2), $30.6\left(\mathrm{CH}_{3}\right), 27.0(\mathrm{C}-1), 14.1(\mathrm{C}-6) . \boldsymbol{\delta}_{\mathrm{F}}\left(377 \mathrm{MHz}, \mathrm{CDCl}_{3}\right):-116.0 . \mathbf{v}_{\max }(\mathrm{ATR}) / \mathrm{cm}^{-1}$ : 733 (C-S), $1047(\mathrm{C}-\mathrm{O}), 1695(\mathrm{C}=\mathrm{O}), 1735(\mathrm{C}=\mathrm{O})$. LRMS: $\left(\mathrm{ESI}^{+}\right) \mathrm{m} / z$ calcd for $\mathrm{C}_{15} \mathrm{H}_{20} \mathrm{O}_{3} \mathrm{~S}\left([\mathrm{M}+\mathrm{H}]^{+}\right)$: 229.1; found: 229.1.

Ethyl 5-(acetylthio)-3-(4-chlorophenyl)pentanoate (2f) 
<smiles>CC(C)(C)[As]CC(=O)C(=O)OCS</smiles>

General procedure B to yield the title compound ( $801 \mathrm{mg}, 2.55$ mmol, $85 \%$ (yield determined by combination of ${ }^{1} \mathrm{H}$ NMR ratio and isolated yield due to MAP contaminant)) as a colourless wax from If (942 mg, $3.00 \mathrm{mmol})$. Purification was achieved by column chromatography on silica gel using $3 \rightarrow 10 \%$

EtOAc/Hexane (v/v). $\mathbf{R}_{\mathbf{f}}=0.30\left(10 \%\right.$ EtOAc/Hexane (v/v)). $\boldsymbol{\delta}_{\mathbf{H}}\left(400 \mathrm{MHz}, \mathrm{CDCl}_{3}\right): 7.30-7.26(\mathrm{~m}, 2 \mathrm{H}$, Ar-H), 7.16-7.11 (m, 2H, Ar-H), 4.02 (q, $\left.J_{5-6}=7.2 \mathrm{~Hz}, 2 \mathrm{H}, \mathrm{H}-5\right), 3.23-3.13$ (m, 1H, H-3), 2.79-2.69 (m, 1H, H-1), 2.66-2.50 (m, 3H, H-1', H-4), 2.30 (s, 3H, SAc), 1.97-1.80 (m, 2H, H-2), 1.14 (t, $J_{6-5}=$ 7.2 Hz, 2H, H-6). $\boldsymbol{\delta}_{\mathrm{C}}\left(101 \mathrm{MHz}, \mathrm{CDCl}_{3}\right): 195.6(\mathrm{C}=\mathrm{O}), 171.6(\mathrm{C}=\mathrm{O}), 141.0$ (q, Ar-C), 132.6 (Ar-CCl), 128.9, 128.8 (Ar-C), 60.5 (C-5), 41.5 (C-4), 40.9 (C-3), 35.6 (C-2), $30.6\left(\mathrm{CH}_{3}\right), 26.9$ (C-1), 14.1 (C-6). $v_{\max }(\mathrm{ATR}) / \mathrm{cm}^{-1}: 739(\mathrm{C}-\mathrm{S}), 833$ (ArC-H bend), $1038(\mathrm{C}-\mathrm{O}), 1690(\mathrm{C}=\mathrm{O}), 1729(\mathrm{C}=\mathrm{O}), 2971(\mathrm{C}-\mathrm{H})$. LRMS: $\left(\mathrm{ESI}^{+}\right) \mathrm{m} / z$ calcd for $\mathrm{C}_{15} \mathrm{H}_{20} \mathrm{O}_{3} \mathrm{SCl}\left([\mathrm{M}+\mathrm{H}]^{+}\right): 315.1$; found: 315.1 .

\section{Ethyl 5-(acetylthio)-3-(4-bromophenyl)pentanoate (2g)}<smiles>CC(C[As]C(C)(C)C)c1ccc(Br)cc1</smiles>

General procedure B to yield the title compound (779 mg, 2.18 mmol, $91 \%$ (yield determined by combination of ${ }^{1} \mathrm{H}$ NMR ratio and isolated yield due to MAP contaminant)) as a colourless wax from 1 g (680 mg, $2.40 \mathrm{mmol})$. Purification was achieved by column chromatography on silica gel using $3 \rightarrow 10 \%$ EtOAc/Hexane (v/v). $\mathbf{R}_{\mathbf{f}}=0.10\left(10 \%\right.$ EtOAc/Hexane (v/v)). $\boldsymbol{\delta}_{\mathbf{H}}\left(400 \mathrm{MHz}, \mathrm{CDCl}_{3}\right): 7.44-7.39(\mathrm{~m}, 2 \mathrm{H}$, Ar-H), 7.09-6.93 (m, 2H, Ar-H), 4.01 (q, $J_{5-6}=7.2$ Hz, 2H, H-5), 3.21-3.10 (m, 1H, H-3), 2.76-2.67 (m, 1H, H-1), 2.63-2.48 (m, 3H, H-1', H-4), 2.28 (s, 3H, SAc), 1.95-1.78 (m, 2H, H-2), 1.12 (t, $J_{6-5}=$ 7.2 Hz, 2H, H-6). $\boldsymbol{\delta}_{\mathbf{C}}\left(101 \mathrm{MHz}, \mathrm{CDCl}_{3}\right): 195.6(\mathrm{C}=\mathrm{O}), 171.6(\mathrm{C}=\mathrm{O}), 141.5$ (q, Ar-C), 131.8, 129.3 (ArC), 120.7 (Ar-CBr), 60.5 (C-5), 41.4 (C-4), 40.9 (C-3), 35.5 (C-2), $30.6\left(\mathrm{CH}_{3}\right), 26.9$ (C-1), 14.1 (C-6). $v_{\max }(\mathrm{ATR}) / \mathrm{cm}^{-1}: 735(\mathrm{C}-\mathrm{S}), 824$ (ArC-H bend), $1074(\mathrm{C}-\mathrm{O}), 1688(\mathrm{C}=\mathrm{O}), 1731(\mathrm{C}=\mathrm{O}), 2980(\mathrm{C}-\mathrm{H})$. HRMS: $\left(\mathrm{APCI}^{+}\right) \mathrm{m} / \mathrm{z}$ calcd for $\mathrm{C}_{15} \mathrm{H}_{20} \mathrm{O}_{3} \mathrm{SBr}\left([\mathrm{M}+\mathrm{H}]^{+}\right)$: 359.0311 ; found: 359.0332 .

\section{Ethyl 5-(acetylthio)-3-(4-nitrophenyl)pentanoate (2h)}<smiles>CC(C(=O)OCS)c1ccc([N+](=O)[O-])cc1</smiles>

5), 3.41-3.31 (m, 1H, H-3), 2.81-2.58 (m, 4H, H-1, H-4), 2.34 (s, 3H, SAc), 2.06-1.89 (m, 2H, H-2), $1.17\left(\mathrm{t}, J_{6-5}=7.1 \mathrm{~Hz}, 2 \mathrm{H}, \mathrm{H}-6\right) . \boldsymbol{\delta}_{\mathrm{C}}\left(101 \mathrm{MHz}, \mathrm{CDCl}_{3}\right)$ : 195.4, $171.2(\mathrm{C}=\mathrm{O}), 150.4$ (q, Ar-C), 147.1 (Ar- 
$\mathrm{CNO}_{2}$ ), 128.6, 123.9 (Ar-C), 60.7 (C-5), 41.3 (C-3), 40.9 (C-4), 35.5 (C-2), $30.6\left(\mathrm{CH}_{3}\right), 26.7$ (C-1), 14.1 (C-6). $v_{\max }(\mathrm{ATR}) / \mathrm{cm}^{-1}: 754$ (C-S), 857 (ArC-H bend), 1031 (C-O), 1347 (N-O), 1521 (N-O), 1692 $(\mathrm{C}=\mathrm{O}), 1733(\mathrm{C}=\mathrm{O}), 2971(\mathrm{C}-\mathrm{H})$. LRMS: $\left(\mathrm{ESI}^{-}\right) \mathrm{m} / z$ calcd for $\mathrm{C}_{15} \mathrm{H}_{19} \mathrm{O}_{5} \mathrm{SBr}([\mathrm{M}+\mathrm{Br}])$ : 404.0; found: 404.0 .

Ethyl 5-(acetylthio)-4-methylpentanoate (2i)<smiles>[3H]COC(=O)CCC(C)C(C)C(=O)O</smiles>

General procedure B to yield the title compound ( $297 \mathrm{mg}, 1.364$ mmol, 88\%) as a colourless wax from $1 \mathbf{i}(220 \mathrm{mg}, 1.55 \mathrm{mmol})$.

Purification was achieved by column chromatography on silica gel using $3 \rightarrow 6 \%$ EtOAc/Hexane $(\mathrm{v} / \mathrm{v})$. $\mathbf{R}_{\mathbf{f}}=0.15(10 \%$ EtOAc/Hexane $(\mathrm{v} / \mathrm{v})) . \boldsymbol{\delta}_{\mathbf{H}}\left(400 \mathrm{MHz}, \mathrm{CDCl}_{3}\right): 4.12\left(\mathrm{q}, J_{6-7}=7.2 \mathrm{~Hz}, 2 \mathrm{H}, \mathrm{H}-5\right), 2.91\left(\mathrm{dd}, J_{1-1}=13.6 \mathrm{~Hz}, J_{1-2}=5.6 \mathrm{~Hz}\right.$, $1 \mathrm{H}, \mathrm{H}-1), 2.77$ (dd, $J_{l^{\prime}-1}=13.6 \mathrm{~Hz}, J_{l^{\prime}-2}=6.8 \mathrm{~Hz}, 2 \mathrm{H}, \mathrm{H}-1^{\prime}$ ), 2.38-2.28 (m, 5-H, H-5, SAc), 1.80-1.62 (m, 2H, H-4), 1.56-1.46 (m, 1H, H-2), 1.25 (t, $\left.J_{7-6}=7.2 \mathrm{~Hz}, 2 \mathrm{H}, \mathrm{H}-7\right), 0.95$ (d, $\left.J_{3-2}=6.7 \mathrm{~Hz}, 3 \mathrm{H}, \mathrm{H}-3\right)$. $\boldsymbol{\delta}_{\mathbf{C}}\left(101 \mathrm{MHz}, \mathrm{CDCl}_{3}\right):$ 195.7, $173.5(\mathrm{C}=\mathrm{O}), 60.3$ (C-6), 35.5 (C-1), 33.0 (C-4), 32.0 (C-5), 30.8 (C-2), $30.7\left(\mathrm{CH}_{3}\right), 18.9(\mathrm{C}-3), 14.2(\mathrm{C}-7) \cdot \mathbf{v}_{\max }(\mathrm{ATR}) / \mathrm{cm}^{-1}: 739(\mathrm{C}-\mathrm{S}), 1035(\mathrm{C}-\mathrm{O}), 1689(\mathrm{C}=\mathrm{O}), 1731(\mathrm{C}=\mathrm{O})$, $2962(\mathrm{C}-\mathrm{H})$. HRMS: $\left(\mathrm{ESI}^{+}\right) \mathrm{m} / z$ calcd for $\mathrm{C}_{10} \mathrm{H}_{18} \mathrm{O}_{3} \mathrm{SNa}\left([\mathrm{M}+\mathrm{Na}]^{+}\right)$: 241.0874; found: 241.0866.

\section{Methyl 5-(acetylthio)-2,2-dimethylpentanoate (2j)}

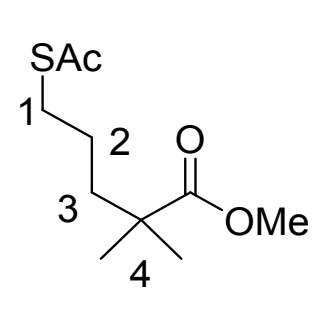

General procedure B to yield the title compound (452 $\mathrm{mg}, 2.07 \mathrm{mmol}, 95 \%)$ as a colourless wax from $\mathbf{1 j}$ (310 $\mathrm{mg}, 2.18 \mathrm{mmol})$. Purification was achieved by column chromatography on silica gel using $2.5 \rightarrow 6.0 \%$ EtOAc/Hexane $(\mathrm{v} / \mathrm{v}) . \mathbf{R}_{\mathbf{f}}$ $=0.22(10 \%$ EtOAc/Hexane $(\mathrm{v} / \mathrm{v})) . \boldsymbol{\delta}_{\mathbf{H}}\left(400 \mathrm{MHz}, \mathrm{CDCl}_{3}\right): 3.67(\mathrm{~s}, 3 \mathrm{H}, \mathrm{OMe})$, $2.86\left(\mathrm{t}, J_{1-2}=7.0 \mathrm{~Hz}, 2 \mathrm{H}, \mathrm{H}-1\right), 2.34$ (s, 3H, SAc), 1.63-1.48 (m, 4H, H-2, H-3), 1.18 (s, 6H, H-4). $\boldsymbol{\delta}_{\mathrm{C}}\left(101 \mathrm{MHz}, \mathrm{CDCl}_{3}\right):$ 195.8, $178.1(\mathrm{C}=\mathrm{O}), 51.7$ (OMe), 42.1 (q-C), 39.6 (C-3), 30.6 $\left(\mathrm{CH}_{3}\right), 29.4(\mathrm{C}-1), 25.2(\mathrm{C}-2), 25.1(\mathrm{C}-4) . v_{\max }(\mathrm{ATR}) / \mathrm{cm}^{-1}$ : $737(\mathrm{C}-\mathrm{S}), 1692(\mathrm{C}=\mathrm{O}), 1731(\mathrm{C}=\mathrm{O}), 2950$ (C-H). HRMS: $\left(\mathrm{ESI}^{+}\right) \mathrm{m} / z$ calcd for $\mathrm{C}_{10} \mathrm{H}_{18} \mathrm{O}_{3} \mathrm{SNa}\left([\mathrm{M}+\mathrm{Na}]^{+}\right)$: 241.0869; found: 241.0870.

Ethyl 5-(acetylthio)-2-(4-methoxybenzyl)-2-methylpentanoate (2k)<smiles>COC(=O)C(C)(CCC(C)C(C)C)Cc1ccc(OC)cc1</smiles>

General procedure B to yield the title compound (1.08 g, $3.20 \mathrm{mmol}$, $93 \%$ ) as a colourless wax from $1 \mathbf{k}(898 \mathrm{mg}, 3.43 \mathrm{mmol})$. Purification 
was achieved by column chromatography on silica gel using $2.5 \rightarrow 6.0 \%$ EtOAc/Hexane (v/v). $\mathbf{R}_{\mathbf{f}}=0.18$ $\left(10 \%\right.$ EtOAc/Hexane (v/v)). $\boldsymbol{\delta}_{\mathbf{H}}\left(400 \mathrm{MHz}, \mathrm{CDCl}_{3}\right): 7.03\left(\mathrm{~d}, J_{A r H-A r H}=8.6 \mathrm{~Hz}, 2 \mathrm{H}, \mathrm{Ar}-\mathrm{H}\right), 6.82\left(\mathrm{~d}, J_{A r H-}\right.$ $\left.{ }_{A r H}=8.6 \mathrm{~Hz}, 2 \mathrm{H}, \mathrm{Ar}-\mathrm{H}\right), 4.13$ (q, $\left.J_{6-7}=7.2 \mathrm{~Hz}, 2 \mathrm{H}, \mathrm{H}-6\right), 3.80(\mathrm{~s}, 3 \mathrm{H}, \mathrm{OMe}), 2.95\left(\mathrm{~d}, J_{5-5}=13.4 \mathrm{~Hz}, 1 \mathrm{H}\right.$, H-5), 2.87 (t, $J_{1-2}=7.2 \mathrm{~Hz}, 2 \mathrm{H}, \mathrm{H}-1$ ), 2.67 (d, $J_{5^{\prime}-5}=13.4 \mathrm{~Hz}, 1 \mathrm{H}, \mathrm{H}-5$ '), 2.35 (s, 3H, SAc), 1.86-1.75 (m, 1H, H-2), 1.67-1.45 (m, 3H, H-2', H-3), 1.26 (t, $\left.J_{7-6}=7.2 \mathrm{~Hz}, 2 \mathrm{H}, \mathrm{H}-7\right), 1.09$ (s, 3H, H-4). $\boldsymbol{\delta}_{\mathbf{C}}(101$ $\mathrm{MHz}, \mathrm{CDCl}_{3}$ ): 195.8, 176.5 (C=O), 158.3 (Ar-COMe), 131.1 (Ar-C), 129.5 (q, Ar-C), 113.4 (Ar-C), 60.4 (C-6), 55.2 (OMe), 47.1 (q-C), 44.6 (C-5), 38.1 (C-2), $30.7\left(\mathrm{CH}_{3}\right), 29.4$ (C-1), 25.1 (C-3), 20.8 (C4), 14.3 (C-7). $v_{\max }(\mathrm{ATR}) / \mathrm{cm}^{-1}: 749$ (C-S), 789 (ArC-H bend), 1053 (C-O), 1250 (C-O), 1658 (C=O), $1729(\mathrm{C}=\mathrm{O}), 2974(\mathrm{C}-\mathrm{H})$. LRMS: $\left(\mathrm{ESI}^{+}\right) \mathrm{m} / z$ calcd for $\mathrm{C}_{18} \mathrm{H}_{27} \mathrm{O}_{4} \mathrm{~S}\left([\mathrm{M}+\mathrm{H}]^{+}\right)$: 339.2; found: 339.2 .

Ethyl 5-(acetylthio)-2-methyl-2-(4-(trifluoromethyl)benzyl)pentanoate (2l)

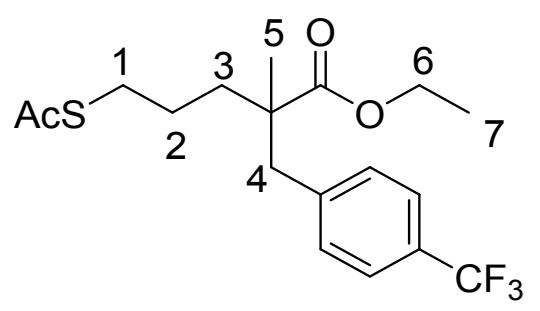

General procedure B to yield the title compound (901 mg, 2.395 mmol, 90\%) as a colourless wax from 11 ( $800 \mathrm{mg}, 2.67 \mathrm{mmol})$. Purification was achieved by column chromatography on silica gel using $2 \rightarrow 5 \%$ EtOAc/Hexane (v/v). $\mathbf{R}_{\mathbf{f}}=0.15$ (10\% EtOAc/Hexane $(\mathrm{v} / \mathrm{v})) . \boldsymbol{\delta}_{\mathbf{H}}\left(400 \mathrm{MHz}, \mathrm{CDCl}_{3}\right): 7.54\left(\mathrm{~d}, J_{A r H-A r H}=8.1 \mathrm{~Hz}, 2 \mathrm{H}, \mathrm{Ar}-\right.$ H), $7.24\left(\mathrm{~d}, J_{A r H-A r H}=8.1 \mathrm{~Hz}, 2 \mathrm{H}, \mathrm{Ar}-\mathrm{H}\right), 4.14\left(\mathrm{q}, J_{6-7}=7.2 \mathrm{~Hz}, 2 \mathrm{H}\right.$, H-6), $3.08\left(\mathrm{~d}, J_{4-4^{\prime}}=13.2 \mathrm{~Hz}, 1 \mathrm{H}, \mathrm{H}-4\right), 2.87\left(\mathrm{t}, J_{1-2}=7.0 \mathrm{~Hz}, 2 \mathrm{H}, \mathrm{H}-1\right), 2.77\left(\mathrm{~d}, J_{4^{\prime}-4}=13.2 \mathrm{~Hz}, 1 \mathrm{H}, \mathrm{H}-\right.$ 4'), 2.35 (s, 3H, SAc), 1.85-1.77 (m, 1H, H-3), 1.70-1.48 (m, 3H, H-2, H-3'), 1.25 (t, $J_{7-6}=7.2 \mathrm{~Hz}, 3 \mathrm{H}$, H-7), 1.11 (s, 3H, H-5). $\boldsymbol{\delta}_{\mathbf{C}}\left(151 \mathrm{MHz}, \mathrm{CDCl}_{3}\right.$ ): 195.8, 175.9 (C=O), 141.7 (q, Ar-C), 130.5 (Ar-C), 128.9 (q, $\left.J_{A r C-F}=32.5 \mathrm{~Hz}, \mathrm{q}, \mathrm{Ar}-\mathrm{C}\right), 124.9$ (q, $\left.J_{A r C-F}=3.7 \mathrm{~Hz}, \mathrm{Ar}-\mathrm{C}\right), 124.3$ (q, $J_{C-F}=271.0 \mathrm{~Hz}, \mathrm{CF}_{3}$ ), 60.6 (C-6), 47.0 (q-C), 45.0 (C-4), 38.3 (C-3), $30.6\left(\mathrm{CH}_{3}\right), 29.3$ (C-1), 25.0 (C-2), 21.0 (C-5), 14.2 (C7). $\boldsymbol{\delta}_{\mathrm{F}}\left(377 \mathrm{MHz}, \mathrm{CDCl}_{3}\right):-62.4 . \boldsymbol{v}_{\max }(\mathrm{ATR}) / \mathrm{cm}^{-1}: 704(\mathrm{C}-\mathrm{S}), 856$ (ArC-H bend), 1221 (C-O), 1691 $(\mathrm{C}=\mathrm{O}), 1715(\mathrm{C}=\mathrm{O}), 2935(\mathrm{C}-\mathrm{H})$. HRMS: $\left(\mathrm{ESI}^{+}\right) \mathrm{m} / z$ calcd for $\mathrm{C}_{18} \mathrm{H}_{23} \mathrm{O}_{3} \mathrm{SF}_{3} \mathrm{Na}\left([\mathrm{M}+\mathrm{Na}]^{+}\right): 399.1213$; found: 399.1212 .

Ethyl 5-(acetylthio)-2-(furan-2-yl(methoxy)methyl)-2-methylpentanoate (2m)

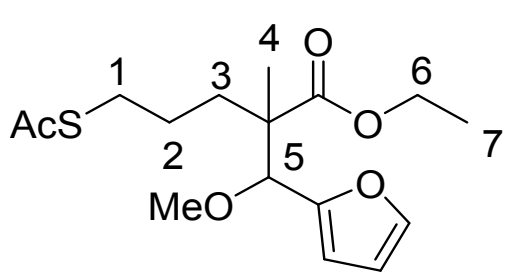

General procedure B to yield the title compound as an inseparable mixture of diasteroisomers $(601 \mathrm{mg}, 1.83 \mathrm{mmol}, 86 \%$ (yield determined by combination of ${ }^{1} \mathrm{H}$ NMR ratio and isolated yield due to MAP contaminant)) as a colourless oiil from $\mathbf{1 m}$ (538 $\mathrm{mg}, 2.14$ 
mmol). Purification was achieved by column chromatography on silica gel using $2 \rightarrow 5 \%$ EtOAc/Hexane $(\mathrm{v} / \mathrm{v}) . \mathbf{R}_{\mathbf{f}}=0.17(10 \%$ EtOAc/Hexane $(\mathrm{v} / \mathrm{v}))$. Major isomer $\boldsymbol{\delta}_{\mathbf{H}}\left(600 \mathrm{MHz}, \mathrm{CDCl}_{3}\right): 7.41-7.39(\mathrm{~m}, 1 \mathrm{H}$, Ar-H), 6.37-6.35 (m, 1H, Ar-H), 6.28 (d, $\left.J_{A r H-A r-H}=3.0 \mathrm{~Hz}, 1 \mathrm{H}, \mathrm{Ar}-\mathrm{H}\right), 4.47$ (s, 1H, H-5), 4.16-4.07 (m, 2H, H-6), 3.27 (s, 3H, OMe), 2.88 (t, $\left.J_{l-2}=7.3 \mathrm{~Hz}, 2 \mathrm{H}, \mathrm{H}-1\right), 2.34$ (s, 3H, SAc), 1.89 (td, $J_{3-3},=12.6$ $\left.\mathrm{Hz}, J_{3-2}=4.5 \mathrm{~Hz}, 1 \mathrm{H}, \mathrm{H}-3\right), 1.73$ (td, $\left.J_{3^{\prime}-3}=12.6 \mathrm{~Hz}, J_{3^{\prime}-2}=5.0 \mathrm{~Hz}, 1 \mathrm{H}, \mathrm{H}-3^{\prime}\right), 1.67-1.48$ (m, 2H, H-2), $1.23\left(\mathrm{t}, J_{7-6}=7.1 \mathrm{~Hz}, 3 \mathrm{H}, \mathrm{H}-7\right), 1.14(\mathrm{~s}, 3 \mathrm{H}, \mathrm{H}-4) . \boldsymbol{\delta}_{\mathbf{C}}\left(151 \mathrm{MHz}, \mathrm{CDCl}_{3}\right): 195.9,174.6(\mathrm{C}=\mathrm{O}), 152.0(\mathrm{q}$, Ar-C), 142.3, 111.0, 109.3 (Ar-C), 82.2 (C-5), 60.6 (C-6), 57.8 (OMe), 51.2 (q-C), 34.8 (C-3), 30.6 $\left(\mathrm{CH}_{3}\right), 29.6$ (C-1), 25.0 (C-2), 17.1 (C-4), 14.2 (C-7). Minor isomer $\boldsymbol{\delta}_{\mathbf{H}}\left(600 \mathrm{MHz}, \mathrm{CDCl}_{3}\right)$ : 7.45-7.43 (m, 1H, Ar-H), 6.41-6.39 (m, 1H, Ar-H), 6.34 (d, $\left.J_{A r H-A r H}=3.2 \mathrm{~Hz}, 1 \mathrm{H}, \mathrm{Ar}-\mathrm{H}\right), 4.56$ (s, 1H, H-5), $4.27-$ 4.16 (m, 2H, H-6), 3.22 (s, 3H, OMe), 2.82-2.74 (m, 2H, H-1), 2.31 (s, 3H, SAc), 1.65-1.48 (m, 3H, H-2, H-3), 1.44-1.35 (m, 1H, H-2'), 1.30 (t, $\left.J_{7-6}=7.1 \mathrm{~Hz}, 3 \mathrm{H}, \mathrm{H}-7\right), 1.22(\mathrm{~s}, 3 \mathrm{H}, \mathrm{H}-4) . \boldsymbol{\delta}_{\mathrm{C}}(151 \mathrm{MHz}$, $\mathrm{CDCl}_{3}$ ): 195.9, 175.1 (C=O), 151.6 (q, Ar-C), 142.5, 110.1, 109.8 (Ar-C), 81.9 (C-5), 60.7 (C-6), 57.4 (OMe), 51.2 (q-C), 35.6 (C-3), $30.6\left(\mathrm{CH}_{3}\right), 29.3$ (C-1), 24.5 (C-2), 15.5 (C-4), 14.3 (C-7). v $v_{\max }$ (ATR)/cm-1: 705 (C-S), 736 (ArC-H bend), 1094 (C-O), 1136 (ArC-O), 1172 (C-O), 1690 (C=O), 1732 $(\mathrm{C}=\mathrm{O}), 2935$ (C-H). LRMS: (ESI-) $\mathrm{m} / z$ calcd for $\mathrm{C}_{16} \mathrm{H}_{24} \mathrm{O}_{5} \mathrm{SCl}\left([\mathrm{M}+\mathrm{Cl}]^{-}\right)$: 363.1; found: 363.1 .

\section{Ethyl 5-(acetylthio)-3,3-dimethylpentanoate (2n)}

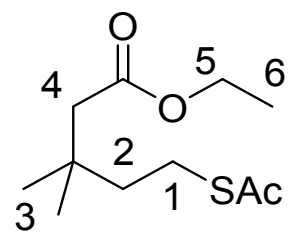

General procedure B to yield the title compound (926 mg, $3.99 \mathrm{mmol}, 95 \%$ ) as a colourless oil from 1n (658 mg, $4.22 \mathrm{mmol})$. Purification was achieved by column chromatography on silica gel using $3 \rightarrow 5 \%$ EtOAc/Hexane (v/v). $\mathbf{R}_{\mathbf{f}}=0.29(10 \%$ EtOAc/Hexane (v/v)). $\boldsymbol{\delta}_{\mathbf{H}}\left(400 \mathrm{MHz}, \mathrm{CDCl}_{3}\right): 4.15$ (q, $\left.J_{5-6}=7.2 \mathrm{~Hz}, 2 \mathrm{H}, \mathrm{H}-5\right)$, 2.91-2.85 (m, 2H, H-1), 2.34 (s, 3H, SAc), 2.25 (s, 2H, H-4), 1.62-1.57 (m, 2H, H-2), $1.28\left(J_{6-5}=7.2 \mathrm{~Hz}, 3 \mathrm{H}, \mathrm{H}-6\right) .1 .07$ (s, 6H, H-3). $\boldsymbol{\delta}_{\mathbf{C}}\left(101 \mathrm{MHz}, \mathrm{CDCl}_{3}\right): 195.9,171.9(\mathrm{C}=\mathrm{O}), 60.1$ (C-5), 45.7 (C-4), 41.6 (C-2), 33.7 (q-C), $30.6\left(\mathrm{CH}_{3}\right), 27.0$ (C-3), 24.5 (C-1), 14.3 (C-6). $v_{\max }(\mathrm{ATR}) / \mathrm{cm}^{-}$ 1: 739 (C-S), $1036(\mathrm{C}-\mathrm{O}), 1691(\mathrm{C}=\mathrm{O}), 1731(\mathrm{C}=\mathrm{O}), 2962(\mathrm{C}-\mathrm{H})$. HRMS: $\left(\mathrm{ESI}^{+}\right) \mathrm{m} / \mathrm{z}$ calcd for $\mathrm{C}_{11} \mathrm{H}_{20} \mathrm{O}_{3} \mathrm{SNa}\left([\mathrm{M}+\mathrm{Na}]^{+}\right)$: 255.1025; found: 255.1024 .

\section{Ethyl 5-(acetylthio)-3-methyl-3-phenylpentanoate (2o)}

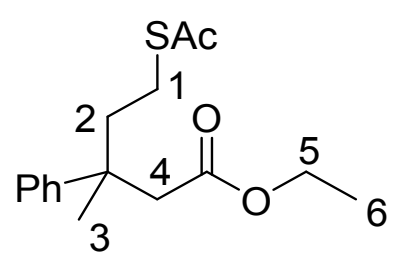

General procedure B to yield the title compound (694 mg, $2.36 \mathrm{mmol}, 90 \%$ ) as a colourless wax from $10(569 \mathrm{mg}, 2.61 \mathrm{mmol})$. Purification was achieved by column chromatography on silica gel using $2.5 \rightarrow 5.5 \%$ EtOAc/Hexane (v/v). $\mathbf{R}_{\mathbf{f}}=0.16(10 \%$ EtOAc/Hexane $(\mathrm{v} / \mathrm{v}))$. $\boldsymbol{\delta}_{\mathbf{H}}(400 \mathrm{MHz}$, $\mathrm{CDCl}_{3}$ ): 7.38-7.33 (m, 4H, Ar-H), 7.27-7.21 (m, $\left.1 \mathrm{H}, \mathrm{Ar}-\mathrm{H}\right), 4.00$ (q, $J_{5-6}=$ 
$7.2 \mathrm{~Hz}, 2 \mathrm{H}, \mathrm{H}-5), 2.76-2.66$ (m, 2H, H-1), 2.57-2.48 (m, 2H, H-4), 2.30 (s, 3H, SAc), 2.19-2.07 (m, 1H, H-2), 2.01-1.91 (m, 1H, H-2'), 1.57 (s, 3H, H-3), 1.10 (t, $\left.J_{6-5}=7.2 \mathrm{~Hz}, 3 \mathrm{H}, \mathrm{H}-6\right) . \boldsymbol{\delta}_{\mathbf{C}}(101 \mathrm{MHz}$, $\mathrm{CDCl}_{3}$ ): 195.8, 171.1 (C=O), 145.0 (q, Ar-C), 128.3, 126.3, 126.1 (Ar-C), 60.1 (C-5), 47.3 (C-4), 42.1 (C-2), 40.6 (q-C), $30.5\left(\mathrm{CH}_{3}\right), 24.6$ (C-1), 24.2 (C-3), 14.0 (C-6). $v_{\max }$ (ATR)/ $\mathrm{cm}^{-1}: 699$ (C-S), 767 (ArC-H bend), $1035(\mathrm{C}-\mathrm{O}), 1691(\mathrm{C}=\mathrm{O}), 1731(\mathrm{C}=\mathrm{O}), 2971(\mathrm{C}-\mathrm{H})$. LRMS: $\left(\mathrm{ESI}^{+}\right) \mathrm{m} / \mathrm{z}$ calcd for $\mathrm{C}_{16} \mathrm{H}_{22} \mathrm{O}_{3} \mathrm{~S}\left([\mathrm{M}+\mathrm{H}]^{+}\right)$: 295.1; found: 295.1 .

\section{Ethyl 2-(1-(2-(acetylthio)ethyl)cyclohexyl)acetate (2p)}

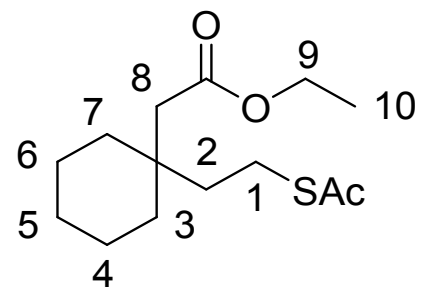

General procedure B to yield the title compound $(392 \mathrm{mg}, 1.68 \mathrm{mmol}$, $84 \%)$ as a colourless oil from $\mathbf{1 p}(658 \mathrm{mg}, 2.00 \mathrm{mmol})$. Purification was achieved by column chromatography on silica gel using $3 \rightarrow 6 \%$ EtOAc/Hexane (v/v). $\mathbf{R}_{\mathbf{f}}=0.23(10 \%$ EtOAc/Hexane $(\mathrm{v} / \mathrm{v})) . \boldsymbol{\delta}_{\mathbf{H}}(400$ $\mathrm{MHz}, \mathrm{CDCl}_{3}$ ): 4.14 (q, $\left.J_{9-10}=7.2 \mathrm{~Hz}, 2 \mathrm{H}, \mathrm{H}-9\right), 2.93-2.86$ (m, 2H, H-1), 2.34 (s, 3H, SAc), 2.33 (s, 2H, H-8), 1.70-1.64 (m, 2H, H-2), 1.61-1.38 (m, 10H, H-3, H-4, H-5, H-6, H-7), 1.28 ( $\left.J_{10-9}=7.2 \mathrm{~Hz}, 3 \mathrm{H}, \mathrm{H}-10\right) . \boldsymbol{\delta}_{\mathrm{C}}\left(101 \mathrm{MHz}, \mathrm{CDCl}_{3}\right): 196.0,172.0$ $(\mathrm{C}=\mathrm{O}), 60.1$ (C-9), 41.7 (C-8), 37.4 (C-2), 36.5 (q-C), 35.7 (C-3, C-7), $30.6\left(\mathrm{CH}_{3}\right), 26.0(\mathrm{C}-5), 23.9$ (C1), 21.5 (C-4, C-6), 14.3 (C-10). $\mathbf{v}_{\max }(\mathrm{ATR}) / \mathrm{cm}^{-1}$ : 739 (C-S), 1038 (C-O), $1683(\mathrm{C}=\mathrm{O}), 1729$ (C=O), 2949 (C-H). LRMS: $\left(\mathrm{ESI}^{+}\right) \mathrm{m} / \mathrm{z}$ calcd for $\mathrm{C}_{14} \mathrm{H}_{24} \mathrm{O}_{3} \mathrm{~S}\left([\mathrm{M}+\mathrm{H}]^{+}\right)$: 273.2; found: 273.2 .

\section{Ethyl 5-(acetylthio)-2,3-dimethylpentanoate (2q)}<smiles>[3H]COC(=O)C(C)C(C)CC[Te]</smiles>

General procedure B to yield the title compound as an inseperable diastereomeric mixture $(1: 1.3,728 \mathrm{mg}, 3.14 \mathrm{mmol}, 93 \%)$ as a colourless wax from 1q $(530 \mathrm{mg}, 3.40 \mathrm{mmol})$. Purification was achieved by column chromatography on silica gel using $2.5 \rightarrow 5.5 \%$

EtOAc/Hexane $(\mathrm{v} / \mathrm{v}) . \mathbf{R}_{\mathbf{f}}=0.21(10 \%$ EtOAc/Hexane $(\mathrm{v} / \mathrm{v}))$. Indistinguishable mixture of isomers $\boldsymbol{\delta}_{\mathbf{H}}$ (400 MHz, $\mathrm{CDCl}_{3}$ ): 4.22-4.01 (m, 4H, H-7), 3.03-2.92 (m, 2H, H-1), 2.89-2.78 (m, 2H, H-1'), 2.442.32 (m, 8H, H-5, SAc), 2.01-1.81 (m, 2H, H-3), 1.75-1.60 (m, 2H, H-2), 1.52-1.40 (m, 2H, H-2'), 1.30-1.25 (m, 6H, H-8), 1.14 (d, $\left.J_{6-5}=7.1 \mathrm{~Hz}, 3 \mathrm{H}, \mathrm{H}-6\right), 1.10$ (d, $\left.J_{6-5}=7.1 \mathrm{~Hz}, 3 \mathrm{H}, \mathrm{H}-6\right), 0.97$ (d, $J_{4-3}$ $=6.9 \mathrm{~Hz}, 3 \mathrm{H}, \mathrm{H}-4), 0.93\left(\mathrm{~d}, J_{4-3}=6.9 \mathrm{~Hz}, 3 \mathrm{H}, \mathrm{H}-4\right) . \boldsymbol{\delta}_{\mathbf{C}}\left(101 \mathrm{MHz}, \mathrm{CDCl}_{3}\right): 195.8,189.9,175.9,175.7$ $(\mathrm{C}=\mathrm{O}), 60.2$, 60.1 (C-7), 44.3, 44.0 (C-5), 35.4, $34.8(\mathrm{C}-3), 34.4,33.3(\mathrm{C}-2), 30.6\left(\mathrm{CH}_{3}\right), 27.0,26.9(\mathrm{C}-$ 1), 16.7, 15.4 (C-4), 14.3, 14.3 (C-8), 13.9, 13.0 (C-6). $v_{\max }$ (ATR)/ $\mathrm{cm}^{-1}: 737$ (C-S), 1072 (C-O), 1690 (C-O), $1729(\mathrm{C}=\mathrm{O}), 2974(\mathrm{C}-\mathrm{H})$. HRMS: $\left(\mathrm{ESI}^{+}\right) \mathrm{m} / z$ calcd for $\mathrm{C}_{11} \mathrm{H}_{20} \mathrm{O}_{3} \mathrm{SNa}\left([\mathrm{M}+\mathrm{Na}]^{+}\right): 255.1025$; found: 255.1024 .

\section{Ethyl 5-(acetylthio)-2-methyl-3-phenylpentanoate (2r)}




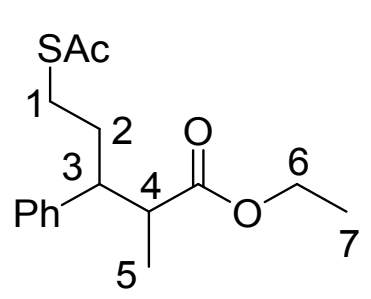

General procedure B to yield the title compound as an inseperable diastereomeric mixture $(1.3: 1,903 \mathrm{mg}, 3.072 \mathrm{mmol}, 96 \%)$ as a colourless wax from 1r (700 mg, $3.2 \mathrm{mmol})$. Purification was achieved by column chromatography on silica gel using $2.5 \rightarrow 5 \%$ EtOAc/Hexane $(\mathrm{v} / \mathrm{v}) . \mathbf{R}_{\mathbf{f}}=0.24$ $\left(10 \%\right.$ EtOAc/Hexane (v/v)). Major Isomer $\boldsymbol{\delta}_{\mathbf{H}}\left(400 \mathrm{MHz}, \mathrm{CDCl}_{3}\right): 7.37-7.15$ (m, 5H, Ar-H), 4.20 (q, $\left.J_{6-7}=7.1 \mathrm{~Hz}, 2 \mathrm{H}, \mathrm{H}-6\right), 2.94-2.84$ (m, 1H, H-3), 2.76-2.69 (m, 1H, H-1), $2.68-$ 2.45 (m, 3H, H-1', H-2), 2.29 (s, 3H, SAc), 2.00-1.82 (m, 2H, H-2), 1.30 (t, $J_{7-6}=7.1 \mathrm{~Hz}, 3 \mathrm{H}, \mathrm{H}-7$ ) $0.93\left(\mathrm{~d} J_{5-4}=7.0 \mathrm{~Hz}, 3 \mathrm{H}, \mathrm{H}-5\right) . \boldsymbol{\delta}_{\mathrm{C}}\left(101 \mathrm{MHz}, \mathrm{CDCl}_{3}\right): 195.6,176.0(\mathrm{C}=\mathrm{O}), 140.8$ (q, Ar-C), 128.7, 128.3127 .0 (Ar-C), 60.5 (C-6), 48.1 (C-3), 46.0 (C-4), 34.0 (C-2), $30.6\left(\mathrm{CH}_{3}\right), 27.2$ (C-1), 16.1 (C-5), 14.3 (C-7). Minor Isomer $\boldsymbol{\delta}_{\mathbf{H}}\left(400 \mathrm{MHz}, \mathrm{CDCl}_{3}\right): 7.37-7.15(\mathrm{~m}, 5 \mathrm{H}, \mathrm{Ar}-\mathrm{H}), 3.90\left(\mathrm{q}, J_{6-7}=7.2 \mathrm{~Hz}, 2 \mathrm{H}\right.$, H-6), 2.94-2.82 (m, 1H, H-3), 2.76-2.58 (m, 2H, H-1, H-4), 2.56-2.45 (m, 1H, H-1'), 2.32 (s, 3H, SAc), 2.01-1.81 (m, 2H, H-2), 1.23 (t, $\left.J_{5-4}=6.9 \mathrm{~Hz}, 3 \mathrm{H}, \mathrm{H}-5\right) 1.00$ (t, $\left.J_{7-6}=7.2 \mathrm{~Hz}, 3 \mathrm{H}, \mathrm{H}-7\right)$. $\boldsymbol{\delta}_{\mathrm{C}}(101$ $\mathrm{MHz}, \mathrm{CDCl}_{3}$ ): 195.7, 175.2 (C=O), 141.4 (q, Ar-C), 128.4, 128.3, 126.9 (Ar-C), 60.1 (C-6), 48.3 (C3), $45.9(\mathrm{C}-4), 31.9(\mathrm{C}-2), 30.6\left(\mathrm{CH}_{3}\right), 27.2(\mathrm{C}-1), 15.0(\mathrm{C}-5), 13.9(\mathrm{C}-7) \cdot v_{\max }(\mathrm{ATR}) / \mathrm{cm}^{-1}: 702(\mathrm{ArC}-$ $\mathrm{H}$ bend), 735 (C-S), 1060 (C-O), $1688(\mathrm{C}=\mathrm{O}), 1727(\mathrm{C}=\mathrm{O}), 2982(\mathrm{C}-\mathrm{H})$. HRMS: $\left(\mathrm{APCI}^{+}\right) \mathrm{m} / \mathrm{z}$ calcd for $\mathrm{C}_{16} \mathrm{H}_{23} \mathrm{O}_{3} \mathrm{~S}\left([\mathrm{M}+\mathrm{H}]^{+}\right)$: 295.1368; found: 295.1363 .

\section{Ethyl 5-(acetylthio)-4-methyl-3-phenylpentanoate (2s)}

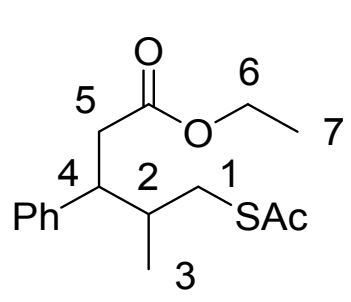

General procedure $\mathrm{B}$ to yield the title compound as an inseperable diastereomeric mixture $(1: 1.4,920 \mathrm{mg}, 3.13 \mathrm{mmol}, 91 \%)$ as a colourless wax from $1 \mathrm{~s}$ (750 mg, $3.44 \mathrm{mmol})$. Purification was achieved by column chromatography on silica gel using $2.5 \rightarrow 8.0 \%$ EtOAc/Hexane $(\mathrm{v} / \mathrm{v}) . \mathbf{R}_{\mathbf{f}}=0.15$ $(10 \% \mathrm{EtOAc} / \mathrm{Hexane}(\mathrm{v} / \mathrm{v}))$. Indistinguishable mixture of isomers $\boldsymbol{\delta}_{\mathbf{H}}(400$ $\mathrm{MHz}, \mathrm{CDCl}_{3}$ ): 7.34-7.29 (m, 4H, Ar-H), 7.25-7.14 (m, 6H, Ar-H), 4.05-3.94 (m, 4H, H-6), 3.25-3.17 (m, 1H, H-4), 3.10-3.02 (m, 1H, H-4), 3.03-2.94 (m, 2H, H-1), 2.86-2.64 (m, 6H, H-1, H-5), 2.37 (s, 4H, SAc), 2.32 (s, 2H, SAc), 2.05-1.92 (m, 2H, H-2), 1.10 (app-q, 6H, H-7), 1.03 (d, J3-2 $=6.9 \mathrm{~Hz}, 2 \mathrm{H}$, $\mathrm{H}-3), 0.84\left(\mathrm{~d}, J_{3-2}=6.9 \mathrm{~Hz}, 4 \mathrm{H}, \mathrm{H}-3\right)$. $\boldsymbol{\delta}_{\mathrm{C}}\left(101 \mathrm{MHz}, \mathrm{CDCl}_{3}\right): 195.7,172.2(\mathrm{C}=\mathrm{O}), 141.9,140.8$ (q, ArC), 128.6, 128.4, 128.2, 126.8, 126.7 (Ar-C), 60.3 (C-2), 46.9, 45.8 (C-4), 38.6, 38.6 (C-5), 38.1, 38.0 (C-2), 34.2, $33.9(\mathrm{C}-1), 30.7,30.6\left(\mathrm{CH}_{3}\right), 16.6,16.3(\mathrm{C}-3), 14.1,14.0(\mathrm{C}-7) \cdot v_{\max }(\mathrm{ATR}) / \mathrm{cm}^{-1}: 702(\mathrm{ArC}-$ $\mathrm{H}$ bend), 736 (C-S), 1031 (C-O), $1690(\mathrm{C}=\mathrm{O}), 1731$ (C=O), 2979 (C-H). HRMS: $\left(\mathrm{APCI}^{+}\right) \mathrm{m} / \mathrm{z}$ calcd for $\mathrm{C}_{16} \mathrm{H}_{23} \mathrm{O}_{3} \mathrm{~S}\left([\mathrm{M}+\mathrm{H}]^{+}\right): 295.1368$; found: 295.1360 .

\section{Ethyl 5-(acetylthio)-4-methylhexanoate (2t)}

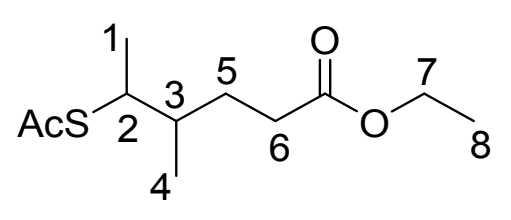

General procedure B to yield the title compound as an inseperable diastereomeric mixture $(1: 1,330 \mathrm{mg}, 1.424 \mathrm{mmol}, 89 \%)$ as a colourless oil from 1t $(250 \mathrm{mg}, 1.603 \mathrm{mmol})$. Purification was 
achieved by column chromatography on silica gel using $3 \rightarrow 5.5 \%$ EtOAc/Hexane $(\mathrm{v} / \mathrm{v}) . \mathbf{R}_{\mathbf{f}}=0.30(10 \%$ EtOAc/Hexane (v/v)). Indistinguishable mixture of isomers $\boldsymbol{\delta}_{\mathbf{H}}\left(400 \mathrm{MHz}, \mathrm{CDCl}_{3}\right): 4.18-4.11(\mathrm{~m}, 4 \mathrm{H}$, H-7), 3.73-3.61 (m, 2H, H-2), 2.45-2.26 (m, 10H, H-5, SAc), 1.88-1.67 (m, 4H, H-3, H-5), 1.58-1.42 (m, 2H, H-5'), 1.32-1.24 (m, 12H, H-1, H-8), 0.97-0.93 (m, 6H, H-4). $\boldsymbol{\delta}_{\mathbf{C}}\left(101 \mathrm{MHz}, \mathrm{CDCl}_{3}\right): 195.7$, 195.7, 173.6, $173.6(\mathrm{C}=\mathrm{O}), 60.4,60.3$ (C-7), 44.1, 44.0 (C-2), 37.6, 37.5 (C-3), 32.3, 32.2 (C-6), 29.2, $29.0\left(\mathrm{CH}_{3}\right), 19.1(\mathrm{C}-8), 16.9(\mathrm{C}-1), 16.2,15.9(\mathrm{C}-4), 14.3(\mathrm{C}-1) . v_{\max }(\mathrm{ATR}) / \mathrm{cm}^{-1}: 737(\mathrm{C}-\mathrm{S}), 1025$ (CO), $1690(\mathrm{C}=\mathrm{O}), 1735(\mathrm{C}=\mathrm{O}), 2970(\mathrm{C}-\mathrm{H})$. HRMS: $\left(\mathrm{APCI}^{+}\right) \mathrm{m} / z$ calcd for $\mathrm{C}_{11} \mathrm{H}_{21} \mathrm{O}_{3} \mathrm{~S}\left([\mathrm{M}+\mathrm{H}]^{+}\right)$: 233.1204; found: 233.1206 .

\section{Ethyl 5-(acetylthio)-4-methyl-5-phenylpentanoate (2u)}

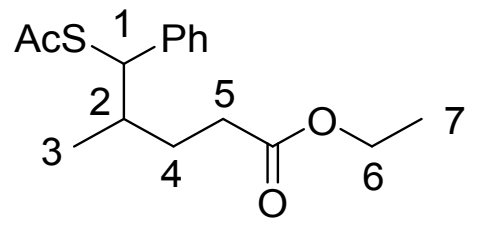

General procedure B to yield the title compound as an inseperable diastereomeric mixture $(1: 1.1,707 \mathrm{mg}, 2.404 \mathrm{mmol}, 81 \%)$ as a colourless wax from 1u $(651 \mathrm{mg}, 2.99 \mathrm{mmol})$. Purification was achieved by column chromatography on silica gel using $2.5 \rightarrow 5.0 \%$ EtOAc/Hexane $(\mathrm{v} / \mathrm{v}) . \mathbf{R}_{\mathbf{f}}=0.17(10 \%$ EtOAc/Hexane $(\mathrm{v} / \mathrm{v}))$. Indistinguishable mixture of isomers $\boldsymbol{\delta}_{\mathbf{H}}$ (101 MHz, $\left.\mathrm{CDCl}_{3}\right)$ : 7.39-7.22 (m, 10H, Ar-H), 4.60 (d, $\left.J_{l-2}=6.9 \mathrm{~Hz} .1 \mathrm{H}, \mathrm{H}-1\right), 4.52$ (d, $J_{1-2}=7.7 \mathrm{~Hz}$. 1H, H-1), 4.19-4.08 (m, 4H, H-6), 2.39-2.28 (m, 10H, H-5, SAc), 2.08-1.70 (m, 5H, H-1, H-4), 1.53$1.14(\mathrm{~m}, 1 \mathrm{H}, \mathrm{H}-2), 1.30-1.23$ (m, 6H, H-7), 1.01 (d, $\left.J_{3-2}=6.8 \mathrm{~Hz}, 3 \mathrm{H}, \mathrm{H}-3\right), 0.88$ (d, $J_{3-2}=6.8 \mathrm{~Hz}, 3 \mathrm{H}$, $\mathrm{H}-3) . \boldsymbol{\delta}_{\mathbf{C}}\left(101 \mathrm{MHz}, \mathrm{CDCl}_{3}\right)$ : 194.4, 194.4, 173.5, 173.5 (C=O), 141.2, 140.8 (q, Ar-C), 128.4, 128.4, 128.2, 128.1, 127.9, 127.2 (Ar-C), 60.4, 60.3 (C-6), 53.7, 53.6 (C-1), 38.0, 37.8 (C-2), 32.0, 31.9 (C-5), $30.6\left(\mathrm{CH}_{3}\right), 29.3,29.2$ (C-4), 17.1, 16.8 (C-3), 14.2 (C-7). $\mathbf{v}_{\max }$ (ATR)/cm- ${ }^{1}: 701$ (ArC-H bend), 732 (C-S), $1085(\mathrm{C}-\mathrm{O}), 1691(\mathrm{C}=\mathrm{O}), 1714(\mathrm{C}=\mathrm{O})$. HRMS: $\left(\mathrm{APCI}^{+}\right) \mathrm{m} / z$ calcd for $\mathrm{C}_{16} \mathrm{H}_{23} \mathrm{O}_{3} \mathrm{~S}\left([\mathrm{M}+\mathrm{H}]^{+}\right)$: 295.1368; found: 295.1364.

\section{Ethyl 5-(acetylthio)-4-methyl-7-phenylheptanoate (2v)}

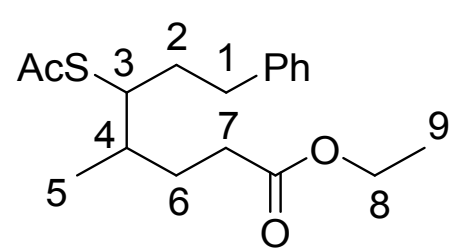

General procedure $\mathrm{B}$ to yield the title compound as an inseperable diastereomeric mixture $(1: 1.1,434 \mathrm{mg}, 1.35 \mathrm{mmol}, 90 \%)$ as a colourless wax from 1v (371 mg, $1.50 \mathrm{mmol}$ ). Purification was achieved by column chromatography on silica gel using $3 \rightarrow 6 \%$ EtOAc/Hexane $(\mathrm{v} / \mathrm{v})$. $\mathbf{R}_{\mathbf{f}}=0.24(10 \%$ EtOAc/Hexane $(\mathrm{v} / \mathrm{v}))$. Indistinguishable mixture of isomers $\boldsymbol{\delta}_{\mathbf{H}}\left(600 \mathrm{MHz}, \mathrm{CDCl}_{3}\right): 7.33-7.27(\mathrm{~m}, 4 \mathrm{H}, \mathrm{Ar}-\mathrm{H}), 7.24-7.17(\mathrm{~m}, 6 \mathrm{H}, \mathrm{Ar}-\mathrm{H}), 4.14$ (app-qd, 4H, H-8), 3.72-3.66 (m, 1H, H-3), 3.62 (app-dt, 1H, H-3), 2.83-2.71 (m, 2H, H-1), 2.66-2.57 (m, 2H, H-1), 2.40-2.20 (m, 10H, SAc, H-7), 1.97-1.70 (m, 8H, H-2, H-6), 1.58-1.50 (m, 1H, H-4), 1.50-1.41 (m, 1H, H-4), 1.27 (app-dt, 6H, H-8), 0.96-0.91 (m, 6H, H-5). $\boldsymbol{\delta}_{\mathbf{C}}\left(151 \mathrm{MHz}, \mathrm{CDCl}_{3}\right.$ ): 195.6, 195.6, 173.6, $173.5(\mathrm{C}=\mathrm{O}), 141.7,141.7$ (q, Ar-C), 128.4, 128.4, 126.0, 126.0 (Ar-C), 60.4, 60.3 (C-8), 49.5, 49.1 (C-3), 37.3, 36.7 (C-4), 33.7, 33.7 (C-1), 32.2, 32.2 (C-7), 30.9, $30.9\left(\mathrm{CH}_{3}\right), 29.5$ (C-2), 28.3 (C- 
6), 16.4, 15.9 (C-5), 14.3 (C-9). $v_{\max }$ (ATR)/cm- ${ }^{-1}: 701$ (ArC-H bend), 737 (C-S), 1059 (C-O), 1688 $(\mathrm{C}=\mathrm{O}), 1717(\mathrm{C}=\mathrm{O}), 2969(\mathrm{C}-\mathrm{H})$. HRMS: $\left(\mathrm{APCI}^{+}\right) \mathrm{m} / z$ calcd for $\mathrm{C}_{18} \mathrm{H}_{27} \mathrm{O}_{3} \mathrm{~S}\left([\mathrm{M}+\mathrm{H}]^{+}\right): 323.1675$; found: 323.1682 .

\section{Methyl 2-(2-(acetylthio)ethyl)benzoate (2w)}<smiles>[Z]c1ccccc1C(=O)OCC(C)(C)C</smiles>

General procedure B to yield the title compound as a colourless oil (481 mg, $2.02 \mathrm{mmol}, 90 \%)$ as a colourless wax from $1 \mathbf{w}(356 \mathrm{mg}, 2.20 \mathrm{mmol})$. Purification was achieved by column chromatography on silica gel using $2.5 \rightarrow 5.5 \%$ EtOAc/Hexane (v/v). $\mathbf{R}_{\mathbf{f}}=0.17\left(10 \%\right.$ EtOAc/Hexane (v/v)). $\boldsymbol{\delta}_{\mathbf{H}}(400$ $\left.\mathrm{MHz}, \mathrm{CDCl}_{3}\right)$ : 7.95-7.92 (m, 1H, Ar-H), 7.51-7.45 (m, 1H, Ar-H), 7.36-7.29 (m, 2H, Ar-H), 3.93 (s, 3H, OMe), 3.27-3.21 (m, 2H, H-1), 3.20-3.15 (m, 2H, H-2), 2.35 (s, 3H, SAc). $\boldsymbol{\delta}_{\mathrm{C}}\left(101 \mathrm{MHz}, \mathrm{CDCl}_{3}\right):$ 195.8, $167.7(\mathrm{C}=\mathrm{O}), 141.7,132.2$ (q, Ar-C), 131.6, 130.9, 129.4, 126.7 (Ar-C), $52.1(\mathrm{OMe}), 34.5(\mathrm{C}-1), 30.7\left(\mathrm{CH}_{3}\right), 30.3(\mathrm{C}-2) . \mathrm{v}_{\max }(\mathrm{ATR}) / \mathrm{cm}^{-1}$ : $733(\mathrm{C}-\mathrm{S}), 1079(\mathrm{C}-\mathrm{O}), 1690(\mathrm{C}=\mathrm{O})$, $1720(\mathrm{C}=\mathrm{O}), 2950(\mathrm{C}-\mathrm{H})$. HRMS: $\left(\mathrm{ESI}^{+}\right) \mathrm{m} / z$ calcd for $\mathrm{C}_{12} \mathrm{H}_{14} \mathrm{O}_{3} \mathrm{SNa}\left([\mathrm{M}+\mathrm{Na}]^{+}\right): 261.0555$; found: 261.0559 .

\section{Ethyl 5-(acetylthio)-2,3,3-trimethylpentanoate (2x)}

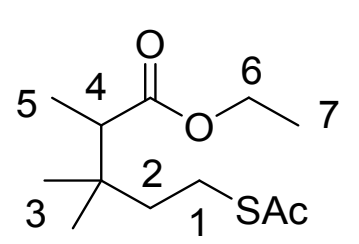

General procedure B to yield the title compound (791 mg, $3.04 \mathrm{mmol}, 93 \%$ ) as a colourless oil from 1x (604 mg, $3.28 \mathrm{mmol})$. Purification was achieved by column chromatography on silica gel using $2.5 \rightarrow 4.5 \%$ EtOAc/Hexane $(\mathrm{v} / \mathrm{v})$. $\mathbf{R}_{\mathbf{f}}=0.22(10 \%$ EtOAc/Hexane $(\mathrm{v} / \mathrm{v})) . \boldsymbol{\delta}_{\mathbf{H}}\left(400 \mathrm{MHz}, \mathrm{CDCl}_{3}\right): 4.14\left(\mathrm{q}, J_{6-7}=\right.$ $7.2 \mathrm{~Hz}, 2 \mathrm{H}, \mathrm{H}-6), 2.90-2.83$ (m, 2H, H-1), 2.41 (q, $\left.J_{4-5}=6.9 \mathrm{~Hz}, 1 \mathrm{H}, \mathrm{H}-4\right), 2.34$ (s, 3H, SAc), 1.581.53 (m, 2H, H-2), 1.28 (t, $\left.J_{7-6}=7.2 \mathrm{~Hz}, 3 \mathrm{H}, \mathrm{H}-7\right), 1.13$ (d, $\left.J_{5-4}=6.9 \mathrm{~Hz}, 3 \mathrm{H}, \mathrm{H}-5\right), 1.01$ (s, 6H, H-3). $\boldsymbol{\delta}_{\mathrm{C}}\left(101 \mathrm{MHz}, \mathrm{CDCl}_{3}\right):$ 195.9, $175.5(\mathrm{C}=\mathrm{O}), 60.0$ (C-6), 47.5 (C-4), $40.2(\mathrm{C}-2), 35.8(\mathrm{q}-\mathrm{C}), 30.6\left(\mathrm{CH}_{3}\right)$, 24.4 (C-1), 24.4 (C-3), 14.3 (C-7), 12.2 (C-5). $v_{\max }$ (ATR)/ $\mathrm{cm}^{-1}$ : 741 (C-S), 1154 (C-O), 1691 (C=O), $1717(\mathrm{C}=\mathrm{O}), 2970(\mathrm{C}-\mathrm{H})$. LRMS: $\left(\mathrm{ESI}^{+}\right) \mathrm{m} / z$ calcd for $\mathrm{C}_{12} \mathrm{H}_{23} \mathrm{O}_{3} \mathrm{~S}\left([\mathrm{M}+\mathrm{H}]^{+}\right)$: 247.1; found: 247.1 .

\section{Methyl 5-(acetylthio)-2,2,4-trimethylpentanoate (2y)}

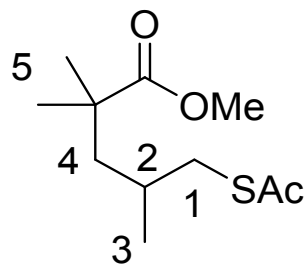

General procedure B to yield the title compound (218 $\mathrm{mg}, 0.94 \mathrm{mmol}, 88 \%)$ as a colourless oil from $1 \mathbf{y}$ (166 mg, $1.06 \mathrm{mmol}$ (yield determined by combination of ${ }^{1} \mathrm{H}$ NMR ratio and isolated yield due to MAP contaminant)). Purification was achieved by column chromatography on silica gel using $3 \rightarrow 5 \%$ EtOAc/Hexane $(\mathrm{v} / \mathrm{v}) . \mathbf{R}_{\mathbf{f}}=0.21(10 \% \mathrm{EtOAc} / \mathrm{Hexane}(\mathrm{v} / \mathrm{v})) . \boldsymbol{\delta}_{\mathbf{H}}\left(400 \mathrm{MHz}, \mathrm{CDCl}_{3}\right): 3.66(\mathrm{~s}, 3 \mathrm{H}$, OMe), $2.89\left(\mathrm{dd}, J_{l-l^{\prime}}=13.6 \mathrm{~Hz}, J_{l-2}=5.6 \mathrm{~Hz}, 1 \mathrm{H}, \mathrm{H}-1\right), 2.68\left(\mathrm{dd}, J_{l^{\prime}-1}=13.6 \mathrm{~Hz}, J_{l^{\prime}-2}=7.5 \mathrm{~Hz}, 1 \mathrm{H}, \mathrm{H}-\right.$ 
1'), 2.32 (s, 3H, SAc), 1.79-1.68 (m, 1H, H-2), 1.64-1.52 (m, 2H, H-4), 1.19 (s, 3H, H-5), 1.17 (s, 3H, H-5'), 0.89 (d, $\left.J_{3-2}=6.6 \mathrm{~Hz}, 3 \mathrm{H}, \mathrm{H}-3\right)$. $\boldsymbol{\delta}_{\mathbf{C}}\left(101 \mathrm{MHz}, \mathrm{CDCl}_{3}\right): 195.7,178.6(\mathrm{C}=\mathrm{O}), 51.7(\mathrm{OMe}), 46.6$ (C-4), 41.7 (q-C), 37.0 (C-1), $30.7\left(\mathrm{CH}_{3}\right), 30.4$ (C-2), 26.7 (C-5), 24.9 (C-5'), 20.0 (C-3). $v_{\max }$ (ATR)/cm ${ }^{-1}: 712$ (C-S), $1108(\mathrm{C}-\mathrm{O}), 1688(\mathrm{C}=\mathrm{O}), 1733(\mathrm{C}=\mathrm{O}), 2973(\mathrm{C}-\mathrm{H})$. HRMS: $\left(\mathrm{ESI}^{+}\right) \mathrm{m} / \mathrm{z}$ calcd for $\mathrm{C}_{11} \mathrm{H}_{20} \mathrm{O}_{3} \mathrm{SNa}\left([\mathrm{M}+\mathrm{Na}]^{+}\right)$: 255.1025; found: 255.1024 . 


\section{Steglich Thiolactonization}

Thiolactones 3a-3y were prepared according to the following sequence:<smiles>[R]C([As])C([R])C([R])([R])C([R])([R])C(=O)OCC</smiles><smiles>[R]C(S)C([R])C([R])([R])C([R])([R])C(=O)O</smiles>

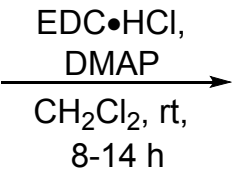<smiles>[R]C1SC(=O)C([R])([R])C([R])([R])C1[R]</smiles>

\section{Tetrahydro-2H-thiopyran-2-one (3a)}

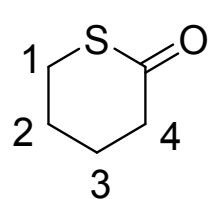

General procedure $\mathrm{C}$ to yield the title compound (74.1 $\mathrm{mg}, 0.639 \mathrm{mmol}, 71 \%$ ) as a colourless wax from $2 \mathbf{a}(183 \mathrm{mg}, 0.900 \mathrm{mmol})$. Purification was achieved using $4 \rightarrow 8 \%$ EtOAc/Hexane (v/v). $\mathbf{R}_{\mathbf{f}}=0.26(10 \%$ EtOAc/Hexane $(\mathrm{v} / \mathrm{v})) . \boldsymbol{\delta}_{\mathbf{H}}\left(400 \mathrm{MHz}, \mathrm{CDCl}_{3}\right)$ : $3.16\left(\mathrm{t}, J_{1-2}=6.2 \mathrm{~Hz}, 2 \mathrm{H}, \mathrm{H}-1\right), 2.61\left(\mathrm{t}, J_{4-3}=6.3 \mathrm{~Hz}, 2 \mathrm{H}, \mathrm{H}-4\right), 2.06-1.94(\mathrm{~m}, 4 \mathrm{H}, \mathrm{H}-$ 2, H-3). $\boldsymbol{\delta}_{\mathbf{C}}\left(101 \mathrm{MHz}, \mathrm{CDCl}_{3}\right): 201.5(\mathrm{C}=\mathrm{O}), 41.3$ (C-4), 30.5 (C-1), 23.0 (C-3), 22.8 (C-2). $\mathbf{v}_{\max }$ (ATR)/cm ${ }^{-1}: 708(\mathrm{C}-\mathrm{S}), 1708(\mathrm{C}=\mathrm{O}), 2938(\mathrm{C}-\mathrm{H})$. LRMS: $\left(\mathrm{ESI}^{+}\right) \mathrm{m} / z$ calcd for $\mathrm{C}_{5} \mathrm{H}_{9} \mathrm{OS}\left([\mathrm{M}+\mathrm{H}]^{+}\right)$: 117.0; found: 117.0 .

\section{3-Methyltetrahydro-2H-thiopyran-2-one (3b)}<smiles>CC1CCC(C(=O)O)C(=O)S1</smiles>

General procedure $\mathrm{C}$ to yield the title compound $(66.0 \mathrm{mg}, 0.511 \mathrm{mmol}, 63 \%$ ) as a colourless wax from $\mathbf{2 b}(177 \mathrm{mg}, 0.811 \mathrm{mmol})$. Purification was achieved using $3 \rightarrow 10 \%$ EtOAc/Hexane $(\mathrm{v} / \mathrm{v}) . \mathbf{R}_{\mathbf{f}}=0.14(10 \%$ EtOAc/Hexane $(\mathrm{v} / \mathrm{v})) . \boldsymbol{\delta}_{\mathbf{H}}(400 \mathrm{MHz}$, $\left.\mathrm{CDCl}_{3}\right): 3.21-3.10$ (m, 2H, H-1), 2.68-2.57 (m, 1H, H-4), 2.14-1.95 (m, 3H, H-2, H3), $1.76-1.61$ (m, 1H, H-3'), 1.19 (d, $\left.J_{5-4}=7.0 \mathrm{~Hz}, 3 \mathrm{H}, \mathrm{H}-5\right)$. $\boldsymbol{\delta}_{\mathrm{C}}\left(101 \mathrm{MHz}, \mathrm{CDCl}_{3}\right)$ : $204.5(\mathrm{C}=\mathrm{O}), 45.1(\mathrm{C}-4), 31.0(\mathrm{C}-3), 31.0(\mathrm{C}-1), 22.3(\mathrm{C}-2), 16.7$ (C-5). $v_{\max }(\mathrm{ATR}) / \mathrm{cm}^{-1}: 707$ (C-S), $1705(\mathrm{C}=\mathrm{O}), 2934(\mathrm{C}-\mathrm{H})$. HRMS: $\left(\mathrm{EI}^{+}\right) \mathrm{m} / z$ calcd for $\mathrm{C}_{6} \mathrm{H}_{10} \mathrm{OS}\left([\mathrm{M}]^{+}\right)$: 130.0451; found: 130.0454 .

\section{4-Phenyltetrahydro-2H-thiopyran-2-one (3c)}<smiles>[Z2]C1CC(=O)SC[C]1c1ccccc1</smiles>

General procedure $\mathrm{C}$ to yield the title compound (91.3 $\mathrm{mg}, 0.476 \mathrm{mmol}, 68 \%$ ) as a colourless wax from $\mathbf{2 c}(196 \mathrm{mg}, 0.700 \mathrm{mmol})$. Purification was achieved using $3 \rightarrow 8 \%$ EtOAc/Hexane (v/v). $\mathbf{R}_{\mathbf{f}}=0.16(10 \%$ EtOAc/Hexane $(\mathrm{v} / \mathrm{v})) . \boldsymbol{\delta}_{\mathbf{H}}\left(400 \mathrm{MHz}, \mathrm{CDCl}_{3}\right)$ : 7.41-7.20 (m, 5H, Ar-H), 3.37-3.28 (m, 1H, H-1), 3.27-3.16 (m, 2H, H-1', H-3), 2.91 $\left(\mathrm{dd}, J_{4-4^{\prime}}=17.4 \mathrm{~Hz}, J_{4-3}=4.5 \mathrm{~Hz}, 1 \mathrm{H}, \mathrm{H}-4\right), 2.76$ (dd, $J_{4^{\prime}-4}=17.4 \mathrm{~Hz}, J_{4^{\prime}-3}=11.1 \mathrm{~Hz}, 1 \mathrm{H}, \mathrm{H}-4^{\prime}$ ), $2.46-$ 2.37 (m, 1H, H-2), 2.21-2.10 (m, 1H, H-2'). $\boldsymbol{\delta}_{\mathbf{C}}\left(101 \mathrm{MHz}, \mathrm{CDCl}_{3}\right): 200.9$ (C=O), 143.7 (q, Ar-C),

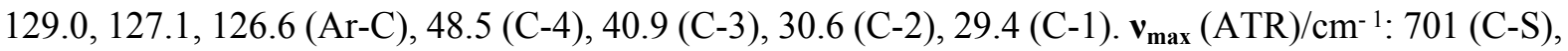
762 (ArC-H bend), $1661(\mathrm{C}=\mathrm{O}), 2938(\mathrm{C}-\mathrm{H})$. LRMS: $\left(\mathrm{ESI}^{+}\right) \mathrm{m} / \mathrm{z}$ calcd for $\mathrm{C}_{11} \mathrm{H}_{12} \mathrm{OSK}\left([\mathrm{M}+\mathrm{K}]^{+}\right): 231.0$; found: 231.0 . 
<smiles>CC1CC(C(C)CSc2ccccc2)CC(=O)S1</smiles>

General procedure $\mathrm{C}$ to yield the title compound (116 mg, $0.536 \mathrm{mmol}, 81 \%)$ as a colourless wax from $\mathbf{2 d}(204 \mathrm{mg}, 0.662 \mathrm{mmol})$. Purification was achieved using $2.5 \rightarrow 6.0 \%$ EtOAc/Hexane $(\mathrm{v} / \mathrm{v}) . \mathbf{R}_{\mathbf{f}}=0.15(10 \%$ EtOAc/Hexane $(\mathrm{v} / \mathrm{v}))$. $\boldsymbol{\delta}_{\mathbf{H}}\left(400 \mathrm{MHz}, \mathrm{CDCl}_{3}\right): 7.36-7.29(\mathrm{~m}, 2 \mathrm{H}, \mathrm{Ar}-\mathrm{H}), 7.26-7.17$ (m, 3H, Ar-H), 3.24-3.11 (m, 2H, H-1), 2.77 (dd, $\left.J_{6-6}=16.5 \mathrm{~Hz}, J_{6-3}=4.4 \mathrm{~Hz} 1 \mathrm{H}, \mathrm{H}-6\right), 2.70$ (t, $J_{5-4}=7.8 \mathrm{~Hz}, 2 \mathrm{H}, \mathrm{H}-$ 5), 2.37 (dd, $\left.J_{6^{\prime}-6}=16.5 \mathrm{~Hz}, J_{6^{\prime}-3}=10.3 \mathrm{~Hz}, 1 \mathrm{H}, \mathrm{H}-6^{\prime}\right), 2.29-2.20$ (m, 1H, H-2), 2.07-1.95 (m, 1H, H3), 1.81-1.65 (m, 3H, H-2', H-4). $\boldsymbol{\delta}_{\mathbf{C}}\left(101 \mathrm{MHz}, \mathrm{CDCl}_{3}\right)$ : $201.4(\mathrm{C}=\mathrm{O}), 141.5$ (q, Ar-C), 128.6, 128.3, 126.1 (Ar-C), 47.4 (C-6), 37.7 (C-4), 34.1 (C-3), 32.7 (C-5), 29.2 (C-1), 29.1 (C-2). $v_{\max }$ (ATR)/cm-1 ${ }^{-1}$ 700 (C-S), 733 (ArC-H bend), $1667(\mathrm{C}=\mathrm{O})$. HRMS: $\left(\mathrm{ESI}^{+}\right) \mathrm{m} / \mathrm{z}$ calcd for $\mathrm{C}_{13} \mathrm{H}_{17} \mathrm{OS}\left([\mathrm{M}+\mathrm{H}]^{+}\right)$: 221.1000; found: 221.0969 .

\section{4-(4-Fluorophenyl)tetrahydro-2H-thiopyran-2-one (3e)}<smiles>[Z]C1SC(=O)C(C)C1c1ccc(F)cc1</smiles>

General procedure D to yield the title compound (107 mg, $0.511 \mathrm{mmol}, 73 \%$ (yield determined by combination of ${ }^{1} \mathrm{H}$ NMR ratio and isolated yield due to MAP contaminant)) as a colourless wax from $2 \mathrm{e}$ (209 $\mathrm{mg}, 0.702 \mathrm{mmol})$. Purification was achieved using $3 \rightarrow 8 \%$ EtOAc/Hexane $(\mathrm{v} / \mathrm{v}) . \mathbf{R}_{\mathbf{f}}=0.11$ $\left(10 \%\right.$ EtOAc/Hexane (v/v)). $\boldsymbol{\delta}_{\mathbf{H}}\left(400 \mathrm{MHz}, \mathrm{CDCl}_{3}\right): 7.21-7.15$ (m, 2H, ArH), 7.08-7.02 (m, 2H, Ar-H), 3.36-3.27 (m, 1H, H-1), 3.26-3.14 (m, 2H, H-1', H-3), 2.88 (dd, $J_{4-4}$ ' = $\left.17.3 \mathrm{~Hz}, J_{4-3}{ }^{\prime}=4.6 \mathrm{~Hz}, 1 \mathrm{H}, \mathrm{H}-4\right), 2.71$ (dd, $\left.J_{4^{\prime}-4}=17.3 \mathrm{~Hz}, J_{4^{\prime}-3}=11.1 \mathrm{~Hz}, 1 \mathrm{H}, \mathrm{H}-4^{\prime}\right), 2.43-2.35$ (m, $1 \mathrm{H}$, H-2), 2.17-2.06 (m, 1H, H-2'). $\boldsymbol{\delta}_{\mathbf{C}}\left(101 \mathrm{MHz}, \mathrm{CDCl}_{3}\right): 200.5(\mathrm{C}=\mathrm{O}), 161.7$ (d, $\left.J_{C-F}=245.4 \mathrm{~Hz}, \mathrm{Ar}-\mathrm{CF}\right)$, $139.4\left(\mathrm{~d}, J_{C-F}=4.4 \mathrm{~Hz}, \mathrm{q}, \mathrm{Ar}-\mathrm{C}\right), 128.1$ (d, $\left.J_{C-F}=8.1 \mathrm{~Hz}, \mathrm{Ar}-\mathrm{C}\right), 115.8$ (d, $\left.J_{C-F}=21.4 \mathrm{~Hz}, \mathrm{Ar}-\mathrm{CF}\right), 48.6$ (C-4), 40.2 (C-3), 30.7 (C-2), 29.3 (C-1). $\boldsymbol{\delta}_{\mathbf{F}}\left(377 \mathrm{MHz}, \mathrm{CDCl}_{3}\right.$ ): -115.6 $\mathbf{v}_{\max }$ (ATR)/ $\mathrm{cm}^{-1}: 706$ (C-S), 835 (ArC-H bend), $1664(\mathrm{C}=\mathrm{O}), 2938(\mathrm{C}-\mathrm{H})$. HRMS: (ESI $\left.{ }^{-}\right) \mathrm{m} / z$ calcd for $\mathrm{C}_{11} \mathrm{H}_{10} \mathrm{OSF}\left([\mathrm{M}-\mathrm{H}]^{+}\right)$: 209.0442; found: 209.0442.

\section{4-(4-Chlorophenyl)tetrahydro-2H-thiopyran-2-one (3f)}<smiles>[2H]C1C(=O)SC(C)C1c1ccc(Cl)cc1</smiles>

General procedure D to yield the title compound $(95.0 \mathrm{mg}, 0.421 \mathrm{mmol}$, $70 \%$ (yield determined by combination of ${ }^{1} \mathrm{H}$ NMR ratio and isolated yield due to MAP contaminant)) as a colourless wax from $\mathbf{2 f}$ (189 $\mathrm{mg}, 0.601$ mmol). Purification was achieved using $3 \rightarrow 10 \%$ EtOAc/Hexane $(\mathrm{v} / \mathrm{v}) . \mathbf{R}_{\mathbf{f}}$ $=0.12(10 \%$ EtOAc/Hexane $(\mathrm{v} / \mathrm{v})) . \boldsymbol{\delta}_{\mathbf{H}}\left(400 \mathrm{MHz}, \mathrm{CDCl}_{3}\right): 7.32-7.27(\mathrm{~m}$, 2H, Ar-H), 7.13-7.09 (m, 2H, Ar-H), 3.31-3.23 (m, 1H, H-1), 3.20-3.10 (m, 2H, H-1', H-3), 2.86-2.78 (m, 1H, H-4), 2.66 (dd, $J_{4^{\prime}-4}=16.7 \mathrm{~Hz}, J_{4^{\prime}-3}=11.1 \mathrm{~Hz}, 1 \mathrm{H}, \mathrm{H}-4^{\prime}$ ), $2.40-2.29$ (m, 1H, H-2), 2.12-2.01 (m, 1H, H-2'). $\boldsymbol{\delta}_{\mathbf{C}}\left(101 \mathrm{MHz}, \mathrm{CDCl}_{3}\right)$ : $200.4(\mathrm{C}=\mathrm{O}), 142.1$ (q, Ar-C), 130.6 (Ar-CCl), 129.1, 128.0 (Ar- 
C), 48.3 (C-4), 40.3 (C-3), 30.5 (C-2), 29.2 (C-1). $v_{\max }$ (ATR)/ $\mathrm{cm}^{-1}: 705$ (C-S), 830 (ArC-H bend), 1664 $(\mathrm{C}=\mathrm{O}), 2938(\mathrm{C}-\mathrm{H})$. HRMS: (APCI-) $\mathrm{m} / z$ calcd for $\mathrm{C}_{11} \mathrm{H}_{10} \mathrm{OSCl}\left([\mathrm{M}-\mathrm{H}]^{-}\right)$: 225.0146; found: 225.0151 .

\section{4-(4-Bromophenyl)tetrahydro-2H-thiopyran-2-one (3g)}<smiles>[Z]C1SC(=O)C(C)C1c1ccc(Br)cc1</smiles>

General procedure $\mathrm{C}$ to yield the title compound $(180 \mathrm{mg}, 0.666 \mathrm{mmol}$, $74 \%$ (yield determined by combination of ${ }^{1} \mathrm{H}$ NMR ratio and isolated yield due to MAP contaminant)) as a colourless wax from $\mathbf{2 g}$ (323 $\mathrm{mg}, 0.903$ $\mathrm{mmol})$. Purification was achieved using $3 \rightarrow 10 \%$ EtOAc/Hexane $(\mathrm{v} / \mathrm{v}) . \mathbf{R}_{\mathbf{f}}$ $=0.10(10 \%$ EtOAc/Hexane $(\mathrm{v} / \mathrm{v})) . \boldsymbol{\delta}_{\mathbf{H}}\left(400 \mathrm{MHz}, \mathrm{CDCl}_{3}\right): 7.50-7.45(\mathrm{~m}$, 2H, Ar-H), 7.10-7.05 (m, 2H, Ar-H), 3.34-3.25 (m, 1H, H-1), 3.22-3.13 (m, 2H, H-1', H-3), 2.86 (ddd, $\left.J_{4-4^{\prime}}=17.1 \mathrm{~Hz}, J_{4-3}=4.6 \mathrm{~Hz}, J_{4-2}=1.2 \mathrm{~Hz} \mathrm{1H}, \mathrm{H}-4\right), 2.69\left(\mathrm{dd}, J_{4^{\prime}-4}=17.1 \mathrm{~Hz}, J_{4^{\prime}-3}=11.0 \mathrm{~Hz}, 1 \mathrm{H}, \mathrm{H}-\right.$ 4'), 2.41-2.33 (m, 1H, H-2), 2.17-2.04 (m, 1H, H-2'). $\boldsymbol{\delta}_{\mathbf{C}}\left(101 \mathrm{MHz}, \mathrm{CDCl}_{3}\right.$ ): 200.3 (C=O), 142.6 (q, Ar-C), 132.1, 128.4 (Ar-C), 120.9 (Ar-CBr), 48.3 (C-4), 40.4 (C-3), 30.5 (C-2), 29.2 (C-1). $v_{\max }$ (ATR)/cm- ${ }^{-1}: 557$ (ArC-Br), 706 (C-S), 830 (ArC-H bend), 1662 (C=O), 2974 (C-H). HRMS: (APCI-) $m / z$ calcd for $\mathrm{C}_{11} \mathrm{H}_{10} \mathrm{OSBr}([\mathrm{M}-\mathrm{H}]-): 268.9641$; found: 268.9633.

\section{4-(4-Nitrophenyl)tetrahydro-2H-thiopyran-2-one (3h)}<smiles>[Z]C1C(=O)SC(C)C1c1ccc([N+](=O)[O-])cc1</smiles>

General procedure $\mathrm{C}$ to yield the title compound (106 $\mathrm{mg}, 0.446 \mathrm{mmol}$, $76 \%)$ as a yellow wax from $\mathbf{2 h}(191 \mathrm{mg}, 0.587 \mathrm{mmol})$. Purification was achieved using $\quad 10 \% \quad$ EtOAc/Hexane $\quad(\mathrm{v} / \mathrm{v}) . \quad \mathbf{R}_{\mathbf{f}}=0.08 \quad(10 \%$ EtOAc/Hexane (v/v)). $\boldsymbol{\delta}_{\mathbf{H}}\left(400 \mathrm{MHz}, \mathrm{CDCl}_{3}\right): 8.23\left(\mathrm{~d}, J_{A r H-A r H}=8.8 \mathrm{~Hz}\right.$, $2 \mathrm{H}, \mathrm{Ar}-\mathrm{H}), 7.41\left(\mathrm{~d}, J_{A r H-A r H}=8.8 \mathrm{~Hz}, 2 \mathrm{H}, \mathrm{Ar}-\mathrm{H}\right) 3.42-3.32(\mathrm{~m}, 2 \mathrm{H}, \mathrm{H}-1$, $\mathrm{H}-3), 3.22\left(\mathrm{dt}, J_{I^{\prime}-1}=12.9, J_{I^{\prime}-2}=4.9 \mathrm{~Hz}, 2 \mathrm{H}, \mathrm{H}-1^{\prime}\right), 2.92\left(\mathrm{dd}, J_{4-4^{\prime}}=17.1 \mathrm{~Hz}, J_{4-3}=4.4 \mathrm{~Hz}, 1 \mathrm{H}, \mathrm{H}-4\right)$, $2.76\left(\mathrm{dd}, J_{4^{\prime}-4}=17.1 \mathrm{~Hz}, J_{4^{\prime}-3}=11.2 \mathrm{~Hz}, 1 \mathrm{H}, \mathrm{H}-4^{\prime}\right), 2.51-2.41$ (m, 1H, H-2), 2.25-2.13 (m, 1H, H-2'). $\boldsymbol{\delta}_{\mathbf{C}}\left(101 \mathrm{MHz}, \mathrm{CDCl}_{3}\right): 199.5(\mathrm{C}=\mathrm{O}), 150.8$ (q, Ar-C), $147.1\left(\mathrm{Ar}-\mathrm{CNO}_{2}\right), 127.7,124.3(\mathrm{Ar}-\mathrm{C}), 47.8(\mathrm{C}-$ 4), 40.8 (C-3), 30.2 (C-2), 29.1 (C-1). $v_{\max }$ (ATR)/ $\mathrm{cm}^{-1}$ : 707 (C-S), 801 (ArC-H bend), 1341 (N-O), 1515 (N-O), $1651(\mathrm{C}=\mathrm{O})$. HRMS: (ESI-) $\mathrm{m} / z$ calcd for $\mathrm{C}_{11} \mathrm{H}_{10} \mathrm{NO}_{3} \mathrm{~S}\left([\mathrm{M}-\mathrm{H}]^{-}\right)$: 236.0387; found: 236.0381 .

\section{5-Methyltetrahydro-2H-thiopyran-2-one (3i)}

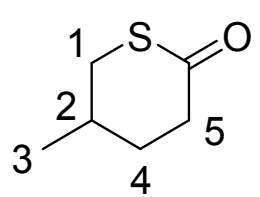

General procedure $\mathrm{C}$ to yield the title compound $(31.5 \mathrm{mg}, 0.242 \mathrm{mmol}, 63 \%)$ as a colourless wax from $2 \mathbf{i}(83.7 \mathrm{mg}, 0.384 \mathrm{mmol})$. Purification was achieved using $4 \rightarrow 8 \%$ EtOAc/Hexane (v/v). $\mathbf{R}_{\mathbf{f}}=0.13(10 \%$ EtOAc/Hexane $(\mathrm{v} / \mathrm{v})) . \boldsymbol{\delta}_{\mathbf{H}}(400 \mathrm{MHz}$, $\left.\mathrm{CDCl}_{3}\right): 3.05\left(\mathrm{dd}, J_{l-1}=12.4 \mathrm{~Hz}, J_{l-2}=4.6 \mathrm{~Hz}, 1 \mathrm{H}, \mathrm{H}-1\right), 2.92\left(\mathrm{dd}, J_{l^{\prime}-1}=12.4 \mathrm{~Hz}\right.$, $\left.J_{l^{\prime}-2}=9.7 \mathrm{~Hz}, 1 \mathrm{H}, \mathrm{H}^{\prime} 1^{\prime}\right), 2.70-2.51(\mathrm{~m}, 2 \mathrm{H}, \mathrm{H}-5), 2.21-2.09(\mathrm{~m}, 1 \mathrm{H}, \mathrm{H}-2), 2.03-1.94(\mathrm{~m}, 1 \mathrm{H}, \mathrm{H}-4)$, $1.72-1.61\left(\mathrm{~m}, 1 \mathrm{H}, \mathrm{H}-4\right.$ ') $1.13\left(\mathrm{~d}, J_{3-2}=6.8 \mathrm{~Hz}, 3 \mathrm{H}, \mathrm{H}-3\right)$. $\boldsymbol{\delta}_{\mathbf{C}}\left(101 \mathrm{MHz}, \mathrm{CDCl}_{3}\right): 201.6(\mathrm{C}=\mathrm{O}), 40.6(\mathrm{C}-$ 
5), 37.0 (C-1), 31.2 (C-4), 28.8 (C-2), 21.2 (C-3). $v_{\max }(\mathrm{ATR}) / \mathrm{cm}^{-1}$ : 712 (C-S), 1694 (C=O), 2878 (CH). HRMS: $\left(\mathrm{EI}^{+}\right) \mathrm{m} / z$ calcd for $\mathrm{C}_{6} \mathrm{H}_{10} \mathrm{OS}\left([\mathrm{M}]^{+}\right): 130.0451$; found: 130.0452 .

\section{3,3-Dimethyltetrahydro-2H-thiopyran-2-one (3j)}

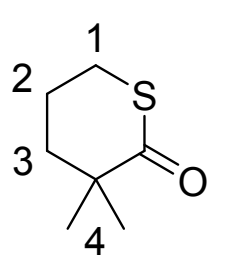

General procedure $\mathrm{C}$ to yield the title compound $(90.1 \mathrm{mg}, 0.626 \mathrm{mmol}, 78 \%)$ as a colourless wax from $\mathbf{2} \mathbf{j}(175 \mathrm{mg}, 0.803 \mathrm{mmol})$. Purification was achieved using $2.5 \rightarrow 4.0 \%$ EtOAc/Hexane (v/v). $\mathbf{R}_{\mathbf{f}}=0.23(10 \%$ EtOAc/Hexane $(\mathrm{v} / \mathrm{v})) . \boldsymbol{\delta}_{\mathbf{H}}(400 \mathrm{MHz}$, $\left.\mathrm{CDCl}_{3}\right): 3.17\left(\mathrm{t}, J_{l-2}=6.4 \mathrm{~Hz}, 2 \mathrm{H}, \mathrm{H}-1\right), 2.08-2.00(\mathrm{~m}, 2 \mathrm{H}, \mathrm{H}-2), 1.85-1.80(\mathrm{~m}, 2 \mathrm{H}, \mathrm{H}-$ 3), 1.25 (s, 6H, H-4). $\boldsymbol{\delta}_{\mathbf{C}}\left(101 \mathrm{MHz}, \mathrm{CDCl}_{3}\right): 207.0$ (C=O), 47.1 (q-C), 38.6 (C-3), 32.4 (C-1), 27.2 (C-4), 19.9 (C-2). $v_{\max }(\mathrm{ATR}) / \mathrm{cm}^{-1}$ : 706 (C-S), 1699 (C=O), 2926 (C-H). LRMS: (ESI) $m / z$ calcd for $\mathrm{C}_{7} \mathrm{H}_{11} \mathrm{OS}\left([\mathrm{M}-\mathrm{H}]^{-}\right)$: 143.1 ; found: 143.1 .

\section{3-(4-Methoxybenzyl)-3-methyltetrahydro-2H-thiopyran-2-one (3k)}

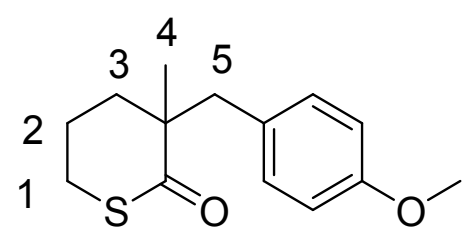

General procedure $\mathrm{C}$ to yield the title compound $(81.6 \mathrm{mg}, 0.326$ mmol, 64\%) as a colourless wax from $2 \mathbf{k}(172 \mathrm{mg}, 0.509 \mathrm{mmol})$. Purification was achieved using $2 \rightarrow 8 \%$ EtOAc/Hexane $(\mathrm{v} / \mathrm{v}) . \mathbf{R}_{\mathbf{f}}=0.13$ $\left(10 \%\right.$ EtOAc/Hexane (v/v)). $\boldsymbol{\delta}_{\mathbf{H}}\left(400 \mathrm{MHz}, \mathrm{CDCl}_{3}\right): 7.08\left(\mathrm{~d}, J_{\text {ArH-ArH }}\right.$ $=8.6 \mathrm{~Hz}, 2 \mathrm{H}, \mathrm{Ar}-\mathrm{H}), 6.84\left(\mathrm{~d}, J_{A r H-A r H}=8.6 \mathrm{~Hz}, 2 \mathrm{H}, \mathrm{Ar}-\mathrm{H}\right), 3.81(\mathrm{~s}, 3 \mathrm{H}, \mathrm{OMe}), 3.21\left(\mathrm{~d}, J_{5-5}=13.7 \mathrm{~Hz}\right.$, 1H, H-5), 3.14-3.07 (m, 2H, H-1), 2.66 (d, $J_{5^{\prime}-5}=13.7$ Hz, 1H, H-5'), 2.06-1.97 (m, 2H, H-3), 1.93$1.83(\mathrm{~m}, 1 \mathrm{H}, \mathrm{H}-2), 1.69-1.59$ (m, 1H, H-2')., 1.26 (s, 3H, H-4) $\boldsymbol{\delta}_{\mathrm{C}}\left(101 \mathrm{MHz}, \mathrm{CDCl}_{3}\right): 206.8(\mathrm{C}=\mathrm{O})$, 158.3 (Ar-COMe), 131.6 (Ar-C), 129.0 (q, Ar-C), 113.5 (Ar-C), 55.2 (OMe), 51.5 (q-C), 44.0 (C-5), 34.7 (C-2), 32.3 (C-1), 25.9 (C-4), 19.7 (C-3). $v_{\max }(\mathrm{ATR}) / \mathrm{cm}^{-1}$ : 732 (C-S), 1171 (C-O), 1676 (C=O), 2982 (C-H). LRMS: $\left(\mathrm{ESI}^{+}\right) \mathrm{m} / z$ calcd for $\mathrm{C}_{14} \mathrm{H}_{19} \mathrm{O}_{2} \mathrm{~S}\left([\mathrm{M}+\mathrm{H}]^{+}\right)$: 251.1; found: 251.1 .

\section{3-Methyl-3-(4-(trifluoromethyl)benzyl)tetrahydro-2H-thiopyran-2-one (3l)}

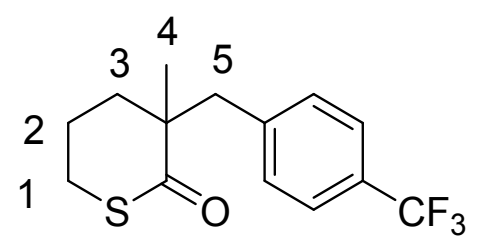

General procedure $\mathrm{C}$ to yield the title compound $(165 \mathrm{mg}, 0.571 \mathrm{mmol}$, $71 \%)$ as a colourless wax from $\mathbf{2 l}(301 \mathrm{mg}, 0.800 \mathrm{mmol})$. Purification was achieved using $2 \rightarrow 6 \%$ EtOAc/Hexane $(\mathrm{v} / \mathrm{v}) . \mathbf{R}_{\mathbf{f}}=0.19(10 \%$ EtOAc/Hexane (v/v)). $\boldsymbol{\delta}_{\mathbf{H}}\left(400 \mathrm{MHz}, \mathrm{CDCl}_{3}\right): 7.54\left(\mathrm{~d}, J_{A r H-A r H}=8.1\right.$ $\mathrm{Hz}, 2 \mathrm{H}, \mathrm{Ar}-\mathrm{H}$ ), 7.27 (d, $\left.J_{A r H-A r H}=8.1 \mathrm{~Hz}, 2 \mathrm{H}, \mathrm{Ar}-\mathrm{H}\right), 3.33$ (d, $\left.J_{5-5}=13.4 \mathrm{~Hz}, 1 \mathrm{H}, \mathrm{H}-5\right), 3.16-3.04$ (m, 2H, H-1), 2.75 (d, $J_{5^{\prime}-5}=13.4$ Hz, 1H, H-5'), 2.07-1.98 (m, 2H, H-2), 1.89-1.80 (m, 1H, H-3), 1.721.64 (m, 1H. H-3'), 1.30 (s, 3H, H-4). $\boldsymbol{\delta}_{\mathbf{C}}\left(151 \mathrm{MHz}, \mathrm{CDCl}_{3}\right.$ ): 206.1 (C=O), 141.3 (q, Ar-C), 131.0 (ArC), 128.9 (q, $\left.J_{A r C-F}=33.0 \mathrm{~Hz}, \mathrm{q}, \mathrm{Ar}-\mathrm{C}\right), 125.0$ (q, $\left.J_{A r C-F}=4.0 \mathrm{~Hz}, \mathrm{Ar}-\mathrm{C}\right), 124.3$ (q, $J_{C-F}=272.6 \mathrm{~Hz}, \mathrm{CF}_{3}$ ), 51.3 (q-C), 44.6 (C-5), 34.8 (C-3), 32.1 (C-1), 26.2 (C-4), 19.6 (C-2). $\boldsymbol{\delta}_{\mathbf{F}}\left(377 \mathrm{MHz}, \mathrm{CDCl}_{3}\right.$ ): -62.4. $\mathbf{v}_{\max }$ (ATR)/cm-1 705 (C-S), 855 (ArC-H bend), 1325 (C-F), 1654 (C=O), 2935 (C-H). HRMS: (ESI ${ }^{+}$) m/z calcd for $\mathrm{C}_{14} \mathrm{H}_{15} \mathrm{OSF}_{3} \mathrm{Na}\left([\mathrm{M}+\mathrm{Na}]^{+}\right)$: 311.0964 ; found: 311.0688 . 
<smiles>COC(c1ccco1)C1(C)CCCSC1=O</smiles>

General procedure $\mathrm{C}$ to yield the title compound as an inseparable mixture of diastereomers $(1: 1.1,73.8 \mathrm{mg}, 0.301 \mathrm{mmol}, 62 \%)$ as a colourless wax from $2 \mathrm{~m}$ (164 mg, $0.500 \mathrm{mmol}$ ). Purification was achieved using $2 \rightarrow 5 \%$ EtOAc/Hexane (v/v). $\mathbf{R}_{\mathbf{f}}=0.19(10 \%$ EtOAc/Hexane $(\mathrm{v} / \mathrm{v}))$. Major isomer $\boldsymbol{\delta}_{\mathbf{H}}$ $\left(600 \mathrm{MHz}, \mathrm{CDCl}_{3}\right): 7.45-7.44(\mathrm{~m}, 1 \mathrm{H}, \mathrm{Ar}-\mathrm{H}), 6.39$ (dd, $\left.J_{A r H-A r H}=3.2 \mathrm{~Hz}, J_{A r H-A r H}=2.0 \mathrm{~Hz}, 1 \mathrm{H}, \mathrm{Ar}-\mathrm{H}\right)$, $6.34\left(\mathrm{~d}, J_{A r H-A r H}=3.2 \mathrm{~Hz}, 1 \mathrm{H}, \mathrm{Ar}-\mathrm{H}\right), 4.80(\mathrm{~s}, 1 \mathrm{H}, \mathrm{H}-5), 3.34\left(\mathrm{td}, J_{l-1}=11.9 \mathrm{~Hz}, J_{l-2}=4.2 \mathrm{~Hz}, 1 \mathrm{H}, \mathrm{H}-\right.$ 1), 3.22 (s, 3H, OMe), 3.06-3.00 (m, 1H, H-1), 2.49-2.40 (m, 1H, H-3), 2.18-2.10 (m, 1H, H-2), 2.00 01.90 (m, 1H, H-2'), 1.74-1.66 (m, 1H, H-3'), 1.07 (s, 3H, H-4). $\boldsymbol{\delta}_{\mathbf{C}}\left(151 \mathrm{MHz}, \mathrm{CDCl}_{3}\right)$ : 205.7 (C=O), 151.3 (q, Ar-C), 142.7, 110.3, 110.0 (Ar-C), 81.5 (C-5), 57.6 (OMe), 54.7 (q-C), 32.0 (C-1), 30.1 (C3), 23.2 (C-4), 19.8 (C-2). Minor isomer $\boldsymbol{\delta}_{\mathbf{H}}\left(600 \mathrm{MHz}, \mathrm{CDCl}_{3}\right)$ : 7.44-7.42 (m, 1H, Ar-H), 6.38 (dd, $\left.J_{A r H-A r H}=3.3 \mathrm{~Hz}, J_{A r H-A r H}=1.7 \mathrm{~Hz}, 1 \mathrm{H}, \mathrm{Ar}-\mathrm{H}\right), 6.29\left(\mathrm{~d}, J_{A r H-A r H}=3.3 \mathrm{~Hz}, 1 \mathrm{H}, \mathrm{Ar}-\mathrm{H}\right), 4.69(\mathrm{~s}, 1 \mathrm{H}, \mathrm{H}-5)$, 3.39-3.31 (m, 1H, H-1), 3.11-2.97 (m, 1H, H-1'), 2.55-2.43 (m, 1H, H-3), 2.09-1.87 (m, 3H, H-2, H3'), 1.44 (s, 3H, H-4). $\boldsymbol{\delta}_{\mathbf{C}}\left(151 \mathrm{MHz}, \mathrm{CDCl}_{3}\right.$ ): 204.8 (C=O), 151.3 (q, Ar-C), 142.3, 110.2, 109.8 (ArC), 81.4 (C-5), 57.6 (OMe), 55.5 (q-C), 31.8 (C-1). 30.8 (C-3), 23.8 (C-4), 19.9 (C-2). $v_{\max }(\mathrm{ATR}) / \mathrm{cm}^{-}$ 1: 700 (C-S), 742 (ArC-H bend), 1097 (C-O), 1156 (ArC-O), 1653 (C=O), 2942 (C-H). LRMS: (ESI $\left.{ }^{+}\right)$ $m / z$ calcd for $\mathrm{C}_{12} \mathrm{H}_{17} \mathrm{O}_{3} \mathrm{~S}\left([\mathrm{M}+\mathrm{H}]^{+}\right)$: 241.1; found: 241.1 .

\section{4,4-Dimethyltetrahydro-2H-thiopyran-2-one (3n)}<smiles>[Z][C@@]1(C)C[CH]SC(=O)C1(C)C</smiles>

General procedure $\mathrm{C}$ to yield the title compound as a colourless wax $(89.4 \mathrm{mg}, 0.621$ mmol, 73\%) from 2n (197 mg, $0.851 \mathrm{mmol}$ ). Purification was achieved using $3 \rightarrow 6 \%$ EtOAc/Hexane (v/v). $\mathbf{R}_{\mathbf{f}}=0.22\left(10 \%\right.$ EtOAc/Hexane (v/v)). $\boldsymbol{\delta}_{\mathbf{H}}\left(400 \mathrm{MHz}, \mathrm{CDCl}_{3}\right)$ : $3.18\left(\mathrm{t}, J_{l-2}=6.3 \mathrm{~Hz}, 2 \mathrm{H}, \mathrm{H}-1\right), 2.40(\mathrm{~s}, 2 \mathrm{H}, \mathrm{H}-4), 1.84\left(\mathrm{t}, J_{2-1}=6.3 \mathrm{~Hz}, 2 \mathrm{H}, \mathrm{H}-2\right), 1.07$ (s, 6H, H-3). $\boldsymbol{\delta}_{\mathrm{C}}\left(101 \mathrm{MHz}, \mathrm{CDCl}_{3}\right): 201.4(\mathrm{C}=\mathrm{O}), 54.6$ (C-4), 35.8 (C-2), 32.5 (q-C), 28.3 (C-3), $27.6(\mathrm{C}-1) \cdot \boldsymbol{v}_{\max }(\mathrm{ATR}) / \mathrm{cm}^{-1}: 704(\mathrm{C}-\mathrm{S}), 1680(\mathrm{C}=\mathrm{O}), 2938(\mathrm{C}-\mathrm{H})$. LRMS: (ESI-) $\mathrm{m} / \mathrm{z}$ calcd for $\mathrm{C}_{7} \mathrm{H}_{12} \mathrm{OS}\left([\mathrm{M}+\mathrm{Cl}]^{-}\right)$: 179.0 ; found: 179.0 .

\section{4-Methyl-4-phenyltetrahydro-2H-thiopyran-2-one (3o)}

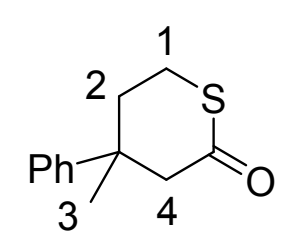

General procedure $\mathrm{C}$ to yield the title compound (111 $\mathrm{mg}, 0.538 \mathrm{mmol}, 77 \%)$ as a colourless wax from $20(205 \mathrm{mg}, 0.699 \mathrm{mmol})$. Purification was achieved using $2.5 \rightarrow 8.0 \%$ EtOAc/Hexane $(\mathrm{v} / \mathrm{v}) . \mathbf{R}_{\mathbf{f}}=0.19(10 \%$ EtOAc/Hexane $(\mathrm{v} / \mathrm{v})) . \boldsymbol{\delta}_{\mathbf{H}}(400$ $\left.\mathrm{MHz}, \mathrm{CDCl}_{3}\right): 7.41-7.35$ (m, 2H, Ar-H), 7.31-7.25 (m, 3H, Ar-H), 3.17 (dd, $J_{4-4}$ ' $\left.=17.0 \mathrm{~Hz}, J_{4-2}=1.6 \mathrm{~Hz} 1 \mathrm{H}, \mathrm{H}-4\right), 3.06-2.99(\mathrm{~m}, 1 \mathrm{H}, \mathrm{H}-1), 2.90-2.82\left(\mathrm{~m}, 1 \mathrm{H}, \mathrm{H}-1\right.$ '), $2.64\left(\mathrm{~d}, J_{4^{\prime}-4}=17.0\right.$ $\mathrm{Hz}, 1 \mathrm{H}, \mathrm{H}-4$ '), 2.53-2.45 (m, 1H, H-2), 2.17-2.08 (m, 1H, 2'), 1.43 (s, 3H, H-3). $\boldsymbol{\delta}_{\mathbf{C}}\left(101 \mathrm{MHz}, \mathrm{CDCl}_{3}\right)$ : $201.2(\mathrm{C}=\mathrm{O}), 145.1$ (q, Ar-C), 128.8, 126.8, 125.5 (Ar-C), 53.1 (C-4), 40.2 (q-C), 36.5 (C-2), 30.7 (C- 
3), 27.3 (C-1). $v_{\max }\left(\right.$ ATR)/ $\mathrm{cm}^{-1}: 712$ (C-S), 760 (ArC-H bend), $1693(\mathrm{C}=\mathrm{O}), 2878$ (C-H). LRMS: $\left(\mathrm{ESI}^{+}\right) \mathrm{m} / z$ calcd for $\mathrm{C}_{12} \mathrm{H}_{14} \mathrm{OSNa}\left([\mathrm{M}+\mathrm{Na}]^{+}\right): 229.1$; found: 229.1 .

\section{3-Thiaspiro[5.5]undecan-2-one (3p)}<smiles>O=C1CCCC2(CCCCC2)C1</smiles>

General procedure $\mathrm{C}$ to yield the title compound as a colourless wax $(52.7 \mathrm{mg}$, $0.287 \mathrm{mmol}, 61 \%)$ from $2 \mathbf{p}(95.1 \mathrm{mg}, 0.470 \mathrm{mmol})$. Purification was achieved using $3 \rightarrow 7 \%$ EtOAc/Hexane $(\mathrm{v} / \mathrm{v}) . \mathbf{R}_{\mathbf{f}}=0.21(10 \%$ EtOAc/Hexane $(\mathrm{v} / \mathrm{v})) . \boldsymbol{\delta}_{\mathbf{H}}(400$ $\mathrm{MHz}, \mathrm{CDCl}_{3}$ ): 3.14 (t, $\left.J_{1-2}=6.4 \mathrm{~Hz}, 2 \mathrm{H}, \mathrm{H}-1\right), 2.46(\mathrm{~s}, 2 \mathrm{H}, \mathrm{H}-8), 1.92\left(\mathrm{t}, J_{2-1}=6.4\right.$ $\mathrm{Hz}, 2 \mathrm{H}, \mathrm{H}-2), 1.59-1.34$ (m, 10H, H-3, H-4, H-5, H-6, H-7). $\boldsymbol{\delta}_{\mathbf{C}}\left(101 \mathrm{MHz}, \mathrm{CDCl}_{3}\right)$ : $201.8(\mathrm{C}=\mathrm{O}), 53.1$ (C-8), 36.7 (C-3, C-7), 35.0 (q-C), 33.3 (C-2), 26.9 (C-1), 25.9 (C-5), $21.3(\mathrm{C}-4, \mathrm{C}-6) . v_{\max }$ (ATR)/ $\mathrm{cm}^{-1}: 706$ (C-S), 1667 (C=O), 2927 (C-H). HRMS: $\left(\right.$ APCI $\left.^{+}\right) \mathrm{m} / \mathrm{z}$ calcd for $\mathrm{C}_{10} \mathrm{H}_{17} \mathrm{OS}\left([\mathrm{M}+\mathrm{H}]^{+}\right)$: 185.1000 ; found: 185.0997 .

\section{3,4-Dimethyltetrahydro-2H-thiopyran-2-one (3q)}<smiles>CC1CCSC(=O)C1C</smiles>

General procedure $\mathrm{C}$ to yield the title compound as an inseperable mixture of diastereomers $(1: 1.3,104 \mathrm{mg}, 0.721 \mathrm{mmol}, 80 \%)$ as a colourless wax from 2q (209 $\mathrm{mg}, 0.901 \mathrm{mmol})$. Purification was achieved using $2.5 \rightarrow 4.0 \%$ EtOAc/Hexane (v/v). $\mathbf{R}_{\mathbf{f}}=0.21(10 \%$ EtOAc/Hexane $(\mathrm{v} / \mathrm{v}))$. Indistinguishable mixture of isomers $\boldsymbol{\delta}_{\mathbf{H}}(400$ $\mathrm{MHz}, \mathrm{CDCl}_{3}$ ) : 3.20-3.11 (m, 4H, H-1), 2.77 (app-p, 1H, H-5), 2.35-2.10 (m, 4H, H-2, H-3, H-5), 1.90-1.72 (m, 3H, H-2', H-3), 1.26 (d, $\left.J_{6-5}=7.1 \mathrm{~Hz}, 3 \mathrm{H}, \mathrm{H}-6\right), 1.16$ (d, $\left.J_{6-5}=7.3 \mathrm{~Hz}, 3 \mathrm{H}, \mathrm{H}-6\right), 1.12$ (d, $\left.J_{4-3}=6.5 \mathrm{~Hz}, 3 \mathrm{H}, \mathrm{H}-4\right), 1.01\left(\mathrm{~d}, J_{4-3}=6.9 \mathrm{~Hz}, 3 \mathrm{H}, \mathrm{H}-4\right) . \boldsymbol{\delta}_{\mathrm{C}}\left(101 \mathrm{MHz}, \mathrm{CDCl}_{3}\right): 204.6,204.6(\mathrm{C}=\mathrm{O})$, 52.3, 49.5 (C-5), 35.8, 33.4 (C-3), 30.3, 28.9 (C-2), 28.6, 28.3 (C-1), 20.7, 16.2 (C-4), 15.4, 13.1 (C-6). $\mathbf{v}_{\max }(\mathrm{ATR}) / \mathrm{cm}^{-1}: 706(\mathrm{C}-\mathrm{S}), 1701(\mathrm{C}=\mathrm{O}), 2927(\mathrm{C}-\mathrm{H})$. LRMS: $\left(\mathrm{ESI}^{-}\right) \mathrm{m} / z$ calcd for $\mathrm{C}_{7} \mathrm{H}_{12} \mathrm{OS}\left([\mathrm{M}+\mathrm{Cl}]^{-}\right)$: 179.0; found: 179.0 .

\section{3-Methyl-4-phenyltetrahydro-2H-thiopyran-2-one (3r)}

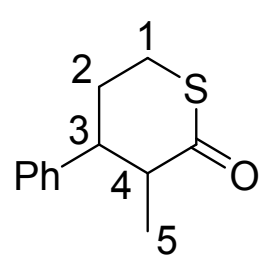

General procedure $\mathrm{C}$ to yield the title compound as a seperable mixture of diastereoisomers $(1.3: 1,99.5 \mathrm{mg}, 0.483 \mathrm{mmol}, 69 \%)$ as a colourless wax from $\mathbf{2 r}$ (206 mg, $0.702 \mathrm{mmol}$ ). Purification was achieved using $3 \rightarrow 7 \%$ EtOAc/Hexane $(\mathrm{v} / \mathrm{v}) . \mathbf{R}_{\mathbf{f}}=0.16(10 \%$ EtOAc/Hexane $(\mathrm{v} / \mathrm{v}))$. Major Isomer $\boldsymbol{\delta}_{\mathbf{H}}\left(400 \mathrm{MHz}, \mathrm{CDCl}_{3}\right)$ : 7.38-7.31 (m, 2H, Ar-H), 7.30-7.24 (m, 1H, Ar-H), 7.22-7.15 (m, 2H, Ar-H), 3.483.40 (m, 1H, H-3), 3.33-3.24 (m, 1H, H-1), 3.17-3.10 (m, 1H, H-1'), 3.06-3.00 (m, 1H, H-4), 2.57$2.48(\mathrm{~m}, 1 \mathrm{H}, \mathrm{H}-2), 2.35-2.24(\mathrm{~m}, 1 \mathrm{H}, \mathrm{H}-2), 1.01$ (d, $\left.J_{5-4}=7.1 \mathrm{~Hz}, 3 \mathrm{H}, \mathrm{H}-5\right) . \boldsymbol{\delta}_{\mathbf{C}}\left(101 \mathrm{MHz}, \mathrm{CDCl}_{3}\right)$ : 204.4 (C=O), 141.6 (q, Ar-C), 128.7, 128.0, 126.9 (Ar-C), 49.4 (C-4), 45.3 (C-3), 28.9 (C-1), 28.3 (C2), 13.5 (C-5). Minor Isomer $\boldsymbol{\delta}_{\mathbf{H}}\left(400 \mathrm{MHz}, \mathrm{CDCl}_{3}\right)$ : 7.40-7.32 (m, 2H, Ar-H), 7.30-7.25 (m, 1H, ArH), 7.23-7.17 (m, 2H, Ar-H), 3.35-3.27 (m, 1H, H-1), 3.23-3.15 (m, 1H, H-1'), 2.91-2.80 (m, 2H, H- 
3, H-4), 2.40-2.19 (m, 2H, H-2), 1.08 (d, $\left.J_{5-4}=6.5 \mathrm{~Hz}, 3 \mathrm{H}, \mathrm{H}-5\right) . \boldsymbol{\delta}_{\mathrm{C}}\left(101 \mathrm{MHz}, \mathrm{CDCl}_{3}\right): 204.0(\mathrm{C}=\mathrm{O})$, 143.9 (q, Ar-C), 128.9, 127.1, 127.0 (Ar-C), 51.6 (C-4), 48.3 (C-3), 31.7 (C-2), 29.3 (C-1), 15.3 (C-5). $\boldsymbol{v}_{\max }(\mathrm{ATR}) / \mathrm{cm}^{-1}$ : $705(\mathrm{C}-\mathrm{S}), 1667(\mathrm{C}=\mathrm{O}), 2930(\mathrm{C}-\mathrm{H})$. LRMS: $\left(\mathrm{ESI}^{+}\right) \mathrm{m} / \mathrm{z}$ calcd for $\mathrm{C}_{12} \mathrm{H}_{15} \mathrm{OS}$ $\left([\mathrm{M}+\mathrm{H}]^{+}\right)$: 207.1; found: 207.1.

\section{5-Methyl-4-phenyltetrahydro-2H-thiopyran-2-one (3s)}

General procedure $\mathrm{C}$ to yield the title compound as an inseperable mixture of
diastereomers $(1: 1.4,131 \mathrm{mg}, 0.638 \mathrm{mmol}, 75 \%)$ as a colourless wax from $2 \mathrm{~s}(250$
$\mathrm{mg}, 0.851 \mathrm{mmol})$. Purification was achieved using $3 \rightarrow 6 \%$ EtOAc/Hexane $(\mathrm{v} / \mathrm{v})$. $\mathbf{R}_{\mathbf{f}}$
$=0.17(10 \%$ EtOAc/Hexane $(\mathrm{v} / \mathrm{v}))$. Indistinguishable mixture of isomer $\boldsymbol{\delta}_{\mathbf{H}}(400$ $\mathrm{MHz}, \mathrm{CDCl}_{3}$ ) : 7.42-7.14 (m, 10H, Ar-H), 3.41-3.34 (m, 1H, H-4), 3.31 (dd, $J_{l-1}=12.4 \mathrm{~Hz}, J_{1-2}=4.2$ $\mathrm{Hz}, 1 \mathrm{H}, \mathrm{H}-1), 3.24$ (dd, $\left.J_{1-1}=12.4 \mathrm{~Hz}, J_{1-2}=4.4 \mathrm{~Hz}, 1 \mathrm{H}, \mathrm{H}-1\right), 3.05-2.89$ (m, 3H, H-1, H-4), 2.87-2.79 (m, 4H, H-5), 2.60-2.49 (m, 1H, H-2), 2.40-2.29 (m, 1H, H-2), 1.05-1.00 (m, 6H, H-3). $\boldsymbol{\delta}_{\mathbf{C}}(101 \mathrm{MHz}$, $\mathrm{CDCl}_{3}$ ): 201.6, 200.9 (C=O), 143.3, 140.7 (q, Ar-C), 128.9, 128.6, 127.9, 127.3, 127.1, 127.1 (Ar-C), 48.0, 47.8 (C-5), 44.6, 43.6 (C-4), 36.2, 35.5 (C-1), 35.4, 32.8 (C-2), 19.7, 14.9 (C-3). $\mathbf{v}_{\max }$ (ATR)/cm1: 705 (C-S), 759 (ArC-H bend), $1708(\mathrm{C}=\mathrm{O}), 2970(\mathrm{C}-\mathrm{H})$. LRMS: $\left(\mathrm{ESI}^{+}\right) \mathrm{m} / \mathrm{z}$ calcd for $\mathrm{C}_{12} \mathrm{H}_{14} \mathrm{OS}$ $\left([\mathrm{M}+\mathrm{Ma}]^{+}\right)$: 229.1; found: 229.1 .

\section{5,6-Dimethyltetrahydro-2H-thiopyran-2-one (3t)}

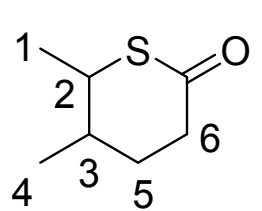

General procedure D to yield the title compound as an inseperable mixture of diastereomers (1:1, $103 \mathrm{mg}, 0.713 \mathrm{mmol}, 81 \%)$ as a colourless wax from $2 \mathbf{t}$ (204 mg, $0.880 \mathrm{mmol})$. Purification was achieved using $3.0 \rightarrow 7.5 \%$ EtOAc/Hexane $(\mathrm{v} / \mathrm{v}) . \mathbf{R}_{\mathbf{f}}=$ $0.20(10 \%$ EtOAc/Hexane $(\mathrm{v} / \mathrm{v}))$. Indistinguishable mixture of isomers $\boldsymbol{\delta}_{\mathbf{H}}(400$ $\mathrm{MHz}, \mathrm{CDCl}_{3}$ ) : 3.71-3.62 (m, 1H, H-2), 3.18 (app-q, 1H, H-2), 2.69-2.45 (m, 4H, H-6), 2.30-2.18 (m, 1H, H-3), 2.00-1.78 (m, 3H, H-5), 1.74-1.61 (m, 2H, H-3, H-5'), 1.32-1.25 (m, 6H, H-4), 1.11 (d, $J_{l-2}$ $=6.4 \mathrm{~Hz}, 3 \mathrm{H}, \mathrm{H}-1), 1.04\left(\mathrm{~d}, J_{l-2}=6.9 \mathrm{~Hz}, 3 \mathrm{H}, \mathrm{H}-1\right) . \boldsymbol{\delta}_{\mathrm{C}}\left(101 \mathrm{MHz}, \mathrm{CDCl}_{3}\right): 202.5,201.9(\mathrm{C}=\mathrm{O}), 46.4$, 44.5 (C-2), 40.9, 37.6 (C-6), 36.5, 31.4 (C-3), 31.4, 28.6 (C-5), 20.9 (C-1), 19.4 (C-4), 18.3 (C-1), 14.0 (C-4). (ATR)/ $\mathrm{cm}^{-1}$ : 706 (C-S), $1667(\mathrm{C}=\mathrm{O}), 2965(\mathrm{C}-\mathrm{H})$. HRMS: $\left(\mathrm{APCI}^{+}\right) \mathrm{m} / z$ calcd for $\mathrm{C}_{7} \mathrm{H}_{13} \mathrm{OS}$ $\left([\mathrm{M}+\mathrm{H}]^{+}\right)$: 145.0700; found: 145.0682 .

\section{5-Methyl-6-phenyltetrahydro-2H-thiopyran-2-one (3u)}

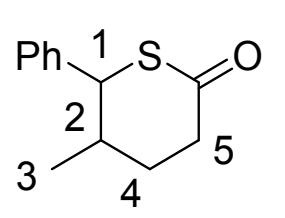

General procedure $\mathrm{C}$ to yield the title compound as an inseperable mixture of diastereomers, with slight traces of the $\gamma$-thiolactone $(1: 1.1,113 \mathrm{mg}, 0.540 \mathrm{mmol}$, $77 \%)$ as a colourless wax from $\mathbf{2 u}(206 \mathrm{mg}, 0.701 \mathrm{mmol})$. Purification was achieved using $2.5 \rightarrow 7.0 \%$ EtOAc/Hexane $(\mathrm{v} / \mathrm{v}) . \mathbf{R}_{\mathbf{f}}=0.17(10 \%$ EtOAc/Hexane $(\mathrm{v} / \mathrm{v}))$. Indistinguishable mixture of isomers $\boldsymbol{\delta}_{\mathbf{H}}\left(400 \mathrm{MHz}, \mathrm{CDCl}_{3}\right): 7.41-7.30(\mathrm{~m}, 10 \mathrm{H}, \mathrm{Ar}-\mathrm{H}), 4.83\left(\mathrm{~d}, J_{l-2}\right.$ 
$=4.4 \mathrm{~Hz}, 1 \mathrm{H}, \mathrm{H}-1), 4.24\left(\mathrm{~d}, J_{1-2}=10.7 \mathrm{~Hz}, 1 \mathrm{H}, \mathrm{H}-1\right), 2.81-2.68(\mathrm{~m}, 4 \mathrm{H}, \mathrm{H}-5), 2.54-2.46(\mathrm{~m}, 1 \mathrm{H}, \mathrm{H}-2)$, 2.29-2.18 (m, H, H-2), 2.12-1.97 (m, 3H, H-4), 1.93-1.80 (m, 1H, H-4'), 0.96-0.92 (m, 6H, H-3). $\boldsymbol{\delta}_{\mathbf{C}}$ (101 MHz, $\left.\mathrm{CDCl}_{3}\right): 201.8,201.4(\mathrm{C}=\mathrm{O}), 139.6,138.3$ (q, Ar-C), 128.9, 128.8, 128.4, 128.4, 128.1, 127.8 (Ar-C), 56.8, 54.2 (C-1), 42.4, 37.9 (C-5), 36.7, 33.3 (C-2), 31.9, 28.8 (C-4), 19.7, 15.1 (C-3). $\boldsymbol{v}_{\max }(\mathrm{ATR}) / \mathrm{cm}^{-1}: 701(\mathrm{C}-\mathrm{S}), 1670(\mathrm{C}=\mathrm{O})$. LRMS: $\left(\mathrm{ESI}^{-}\right) \mathrm{m} / \mathrm{z}$ calcd for $\mathrm{C}_{12} \mathrm{H}_{14} \mathrm{OSBr}\left([\mathrm{M}+\mathrm{Br}]^{-}\right): 285.0$; found: 285.0 .

\section{5-Methyl-6-phenethyltetrahydro-2H-thiopyran-2-one (3v)}

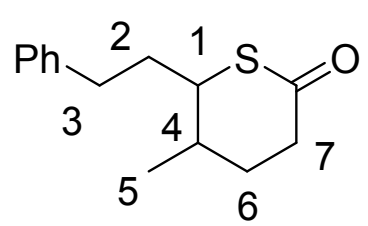

General procedure $\mathrm{C}$ to yield the title compound as an inseperable mixture of diastereomers $(1: 1.1,154 \mathrm{mg}, 0.657 \mathrm{mmol}, 66 \%)$ as a colourless wax from 2v (321 mg, $0.995 \mathrm{mmol}$ ). Purification was achieved using $3 \rightarrow 10 \%$ EtOAc/Hexane $\quad(\mathrm{v} / \mathrm{v}) . \quad \mathbf{R}_{\mathbf{f}}=0.13 \quad(10 \% \quad$ EtOAc/Hexane $\quad(\mathrm{v} / \mathrm{v}))$. Indistinguishable mixture of isomer $\boldsymbol{\delta}_{\mathbf{H}}\left(400 \mathrm{MHz}, \mathrm{CDCl}_{3}\right): 7.36-7.20(\mathrm{~m}, 10 \mathrm{H}, \mathrm{Ar}-\mathrm{H}), 3.61-3.55(\mathrm{~m}$, $1 \mathrm{H}, \mathrm{H}-1), 3.18\left(\mathrm{td}, J_{1-2}=9.1 \mathrm{~Hz}, J_{l-4}=3.3 \mathrm{~Hz}, 1 \mathrm{H}, \mathrm{H}-1\right), 2.89-2.76(\mathrm{~m}, 2 \mathrm{H}, \mathrm{H}-3), 2.73-2.51(\mathrm{~m}, 6 \mathrm{H}$, H-3, H-7), 2.38-2.28 (m, 1H, H-4), 2.20-2.10 (m, 1H, H-2), 2.06-1.95 (m, 4H, H-2, H-6), 1.94-1.83 (m, 3H, H-4, H-6), 1.78-1.67 (m, 1H, H-6), 1.16 (d, $\left.J_{5-4}=6.6 \mathrm{~Hz}, 3 \mathrm{H}, \mathrm{H}-5\right), 1.11$ (d, $J_{5-4}=7.0 \mathrm{~Hz}, 3 \mathrm{H}$, H-5). $\boldsymbol{\delta}_{\mathbf{C}}\left(101 \mathrm{MHz}, \mathrm{CDCl}_{3}\right.$ ): 202.1, 201.7 (C=O), 141.0, 140.8 (q, Ar-C), 128.6, 128.6, 128.5, 126.3, 126.2 (Ar-C), 51.4, 49.4 (C-1), 40.3 (C-7), 37.3, 37.0 (C-2), 34.6 (C-6), 33.8 (C-4), 33.0, 32.1 (C-3), 30.8 (C-6), 30.2 (C-4), 19.6, 13.3 (C-5). $v_{\max }(\mathrm{ATR}) / \mathrm{cm}^{-1}$ : 701 (C-S), 750 (C-H bend), 1667 (C=O), 2935 (C-H). LRMS: (ESI-) $\mathrm{m} / z$ calcd for $\mathrm{C}_{14} \mathrm{H}_{18} \mathrm{OSBr}\left([\mathrm{M}+\mathrm{Br}]^{-}\right)$: 313.0; found: 313.0 .

\section{Isothiochroman-1-one (3w)}<smiles>O=C1SCCc2ccccc21</smiles>

General procedure D to yield the title compound as a colourless wax (104 mg, 0.632 mmol, 79\%) from $\mathbf{2 w}$ (191 mg, $0.802 \mathrm{mmol})$. Purification was achieved using $2.5 \rightarrow 6.0 \%$ EtOAc/Hexane $(\mathrm{v} / \mathrm{v}) . \mathbf{R}_{\mathbf{f}}=0.19(10 \%$ EtOAc/Hexane $(\mathrm{v} / \mathrm{v})) . \boldsymbol{\delta}_{\mathbf{H}}(400$ $\mathrm{MHz}, \mathrm{CDCl}_{3}$ ) : 7.98-7.94 (m, 1H, Ar-H), 7.53-7.48 (m, 1H, Ar-H), 7.40 (app-t, 1H, Ar-H), 7.28-7.24 (m, 1H, Ar-H), 3.34-3.22 (m, 4H, H-1, H-2). $\boldsymbol{\delta}_{\mathbf{C}}(101 \mathrm{MHz}$, $\mathrm{CDCl}_{3}$ ): $191.1(\mathrm{C}=\mathrm{O}), 141.0,133.3$ (q, Ar-C), 132.4, 129.0, 127.6, 126.7 (Ar-C), 30.5 (C-2), 28.8 (C1). $\boldsymbol{v}_{\max }(\mathrm{ATR}) / \mathrm{cm}^{-1}{ }^{1}: 648$ (ArC-H bend), 703 (C-S), $1637(\mathrm{C}=\mathrm{O})$. LRMS: (ESI $\left.{ }^{-}\right) \mathrm{m} / z$ calcd for $\mathrm{C}_{9} \mathrm{H}_{8} \mathrm{OSCl}([\mathrm{M}+\mathrm{Cl}]$ ) $)$ 199.0; found: 199.0. 


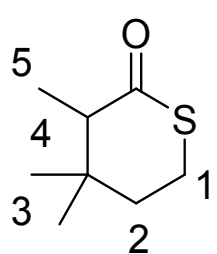

General procedure $\mathrm{C}$ to yield the title compound as a colourless wax $(87.5 \mathrm{mg}, 0.554$ mmol, 74\%) from 2x (195 mg, $0.749 \mathrm{mmol})$. Purification was achieved using $2 \rightarrow 5 \%$ EtOAc/Hexane (v/v). $\mathbf{R}_{\mathbf{f}}=0.25(10 \%$ EtOAc/Hexane $(\mathrm{v} / \mathrm{v})) . \boldsymbol{\delta}_{\mathbf{H}}\left(400 \mathrm{MHz}, \mathrm{CDCl}_{3}\right)$ : 3.20-3.08 (m, 2H, H-1), 2.44 (q, $\left.J_{4-5}=7.0 \mathrm{~Hz}, 1 \mathrm{H}, \mathrm{H}-4\right), 1.97-1.82$ (m, 2H, H-2), 1.19 (d, $\left.J_{5-4}=7.0 \mathrm{~Hz}, 3 \mathrm{H}, \mathrm{H}-5\right), 1.10$ (s, 3H, H-3), 0.99 (s, 3H, H-3'). $\boldsymbol{\delta}_{\mathbf{C}}\left(101 \mathrm{MHz}, \mathrm{CDCl}_{3}\right)$ : $204.8(\mathrm{C}=\mathrm{O}), 55.8$ (C-4), 35.4 (C-2), 34.7 (q-C), 28.7 (C-3), 26.8 (C-1), 23.9 (C-3'), 11.6 (C-5). $\mathbf{v}_{\max }$ (ATR)/cm- ${ }^{-1}: 701$ (C-S), $1661(\mathrm{C}=\mathrm{O}), 2929(\mathrm{C}-\mathrm{H})$. LRMS: (ESI-) $\mathrm{m} / z$ calcd for $\mathrm{C}_{8} \mathrm{H}_{14} \mathrm{OS}\left([\mathrm{M}+\mathrm{Br}]^{-}\right)$: 237.0; found: 237.0 .

\section{3,3,5-Trimethyltetrahydro-2H-thiopyran-2-one (3y)}

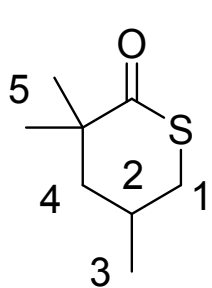

General procedure $\mathrm{C}$ to yield the title compound as a colourless wax $(51.9 \mathrm{mg}, 0.328$ mmol, 77\%) from $\mathbf{2 w}$ (98.8 mg, $0.426 \mathrm{mmol}$ ). Purification was achieved using $3 \rightarrow 7 \%$ EtOAc/Hexane $(\mathrm{v} / \mathrm{v}) . \mathbf{R}_{\mathbf{f}}=0.22(10 \%$ EtOAc/Hexane $(\mathrm{v} / \mathrm{v})) . \boldsymbol{\delta}_{\mathbf{H}}\left(400 \mathrm{MHz}, \mathrm{CDCl}_{3}\right)$ : 3.05-2.90 (m, 2H, H-1), 2.39-2.25 (m, 1H, H-2), 1.75-1.62 (m, 2H, H-4), 1.30 (s, 3H, H-5), 1.21 (s, 3H, H-5'), 1.11 (d, $\left.J_{3-2}=6.5 \mathrm{~Hz}, 3 \mathrm{H}, \mathrm{H}-3\right)$. $\boldsymbol{\delta}_{\mathbf{C}}\left(101 \mathrm{MHz}, \mathrm{CDCl}_{3}\right): 207.1$ $(\mathrm{C}=\mathrm{O}), 47.5$ (C-4), 47.4 (q-C), 38.7 (C-1), 27.9 (C-5), 27.3 (C-5'), 26.2 (C-2), 22.2 (C-3). $v_{\max }$ (ATR)/cm- ${ }^{-1}: 703$ (C-S), $1664(\mathrm{C}=\mathrm{O}), 2923(\mathrm{C}-\mathrm{H})$. LRMS: (ESI-) $\mathrm{m} / z$ calcd for $\mathrm{C}_{8} \mathrm{H}_{13} \mathrm{OS}\left([\mathrm{M}-\mathrm{H}]^{-}\right)$: 157.1; found: 157.1 . 


\section{Gram-Scale Preparation of $\delta$-Thiolactone}

A gram-scale synthesis of $\mathbf{3} \mathbf{c}$ was conducted according to the following sequence:

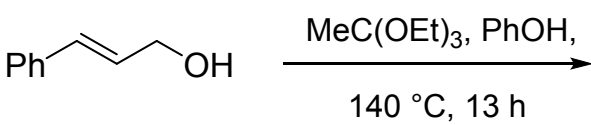

$140{ }^{\circ} \mathrm{C}, 13 \mathrm{~h}$<smiles>CCOC(=O)CC(CC[As])c1ccccc1</smiles>

2c, $94 \%$ $3.42 \mathrm{~g}$<smiles>C=CC(CC(=O)OCC)Pc1ccccc1</smiles>

$1 \mathrm{c}, 87 \%$

$2.75 \mathrm{~g}$

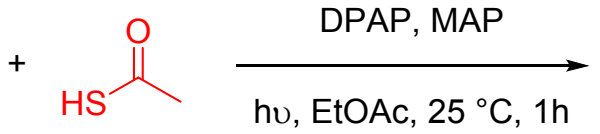

hu, EtOAc, $25^{\circ} \mathrm{C}, 1 \mathrm{~h}$

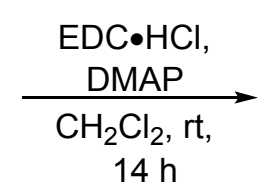

$14 \mathrm{~h}$

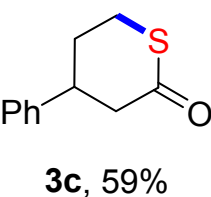

$1.38 \mathrm{~g}$

\section{Ethyl 3-phenylpent-4-enoate (1c)}

To a stirred solution of cinnamyl alcohol $(2.01 \mathrm{~g}, 15 \mathrm{mmol}, 1.0$ equiv.) in triethyl orthoacetate (5.75 $\mathrm{mL}, 31.5 \mathrm{mmol}, 2.1$ equiv.) was added $\mathrm{PhOH}(141 \mathrm{mg}, 1.50 \mathrm{mmol}, 0.1$ equiv.) and the mixture was heated at $140{ }^{\circ} \mathrm{C}$ for $13 \mathrm{~h}$. After this time, the apparatus was rearranged for distillation at $175^{\circ} \mathrm{C}$. After distilling for $1 \mathrm{~h}$, the remaining yellow oil was cooled to rt. No further purification was required as the title compound (2.75 g, $13.1 \mathrm{mmol}, 87 \%$ ) was of sufficient purity for the next step.

\section{Ethyl 5-(acetylthio)-3-phenylpentanoate (2c)}

To solution of $1 \mathrm{c}(2.75 \mathrm{~g}, 13.1 \mathrm{mmol}, 1.0$ equiv.), in HPLC grade EtOAc (65 mL, direct from the bottle) was added DPAP (335 mg, $1.31 \mathrm{mmol}, 0.1$ equiv.), MAP (197 mg, $1.31 \mathrm{mmol}, 0.1$ equiv.) and HSAc ( $2.8 \mathrm{~mL}, 39.3 \mathrm{mmol}, 3.0$ equiv.) and the reaction mixture was irradiated in the UV oven for $1 \mathrm{~h}$ at 25 ${ }^{\circ} \mathrm{C}$. The solvent was removed in vacuo and purification was achieved by column chromatography on silica gel using $3 \rightarrow 6 \%$ EtOAc/Hexane (v/v) to furnish the title compound as a yellow oil $(3.42 \mathrm{~g}, 12.2$ mmol, 94\%).

\section{4-Phenyltetrahydro-2H-thiopyran-2-one (3c)}

To $2 \mathrm{c}$ (3.42 g, $12.2 \mathrm{mmol}, 1.0$ equiv.) was added $1 \mathrm{M} \mathrm{NaOH}$ in $10 \% \mathrm{H}_{2} \mathrm{O} / \mathrm{MeOH}(40 \mathrm{~mL})$ and the mixture was stirred for $1 \mathrm{~h}$ at $90{ }^{\circ} \mathrm{C}$. The mixture was cooled to rt, diluted with an aqueous $1 \mathrm{M} \mathrm{NaOH}$ solution, and poured into a separating funnel. The aqueous phase was extracted twice with $\mathrm{CH}_{2} \mathrm{Cl}_{2}$, and the organic phases were discarded. The aqueous phase was acidified with aqueous $4 \mathrm{M} \mathrm{HCl}$ solution and extracted five times with $\mathrm{CH}_{2} \mathrm{Cl}_{2}$. The combined organic layers were dried over $\mathrm{MgSO}_{4}$, filtered and the solvent removed in vacuo to yield the 5-mercaptopentanoic acid, without further purification. 
The 5-mercaptopentanoic acid was then dissolved in HPLC grade $\mathrm{CH}_{2} \mathrm{Cl}_{2}(80 \mathrm{~mL}$, direct from the bottle) and cooled to $0{ }^{\circ} \mathrm{C}$. $\mathrm{EDC} \cdot \mathrm{HCl}(4.61 \mathrm{~g}, 24 \mathrm{mmol}, 2.0$ equiv. $)$ and DMAP (1.76 g, $14.4 \mathrm{mmol}, 1.2$ equiv.) were added. After 30 mins, the reaction was warmed to rt and stirred for $14 \mathrm{~h}$. The solvent was removed in vacuo and the crude product was purified by column chromatography on silica gel using $3 \rightarrow 8 \%$ EtOAc/Hexane (v/v) to furnish the title compound as a yellow oil (1.38 g, $7.20 \mathrm{mmol}, 59 \%)$. 
7. NMR Spectra

A) NMR Spectra of $\boldsymbol{\gamma}$-Unsaturated Esters

Supplementary Figure S1.

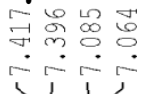

$\sqrt{1}$

(400 MHz, CDCl3).

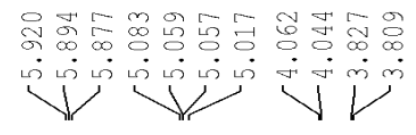

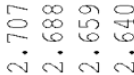

V

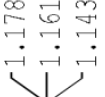

焉
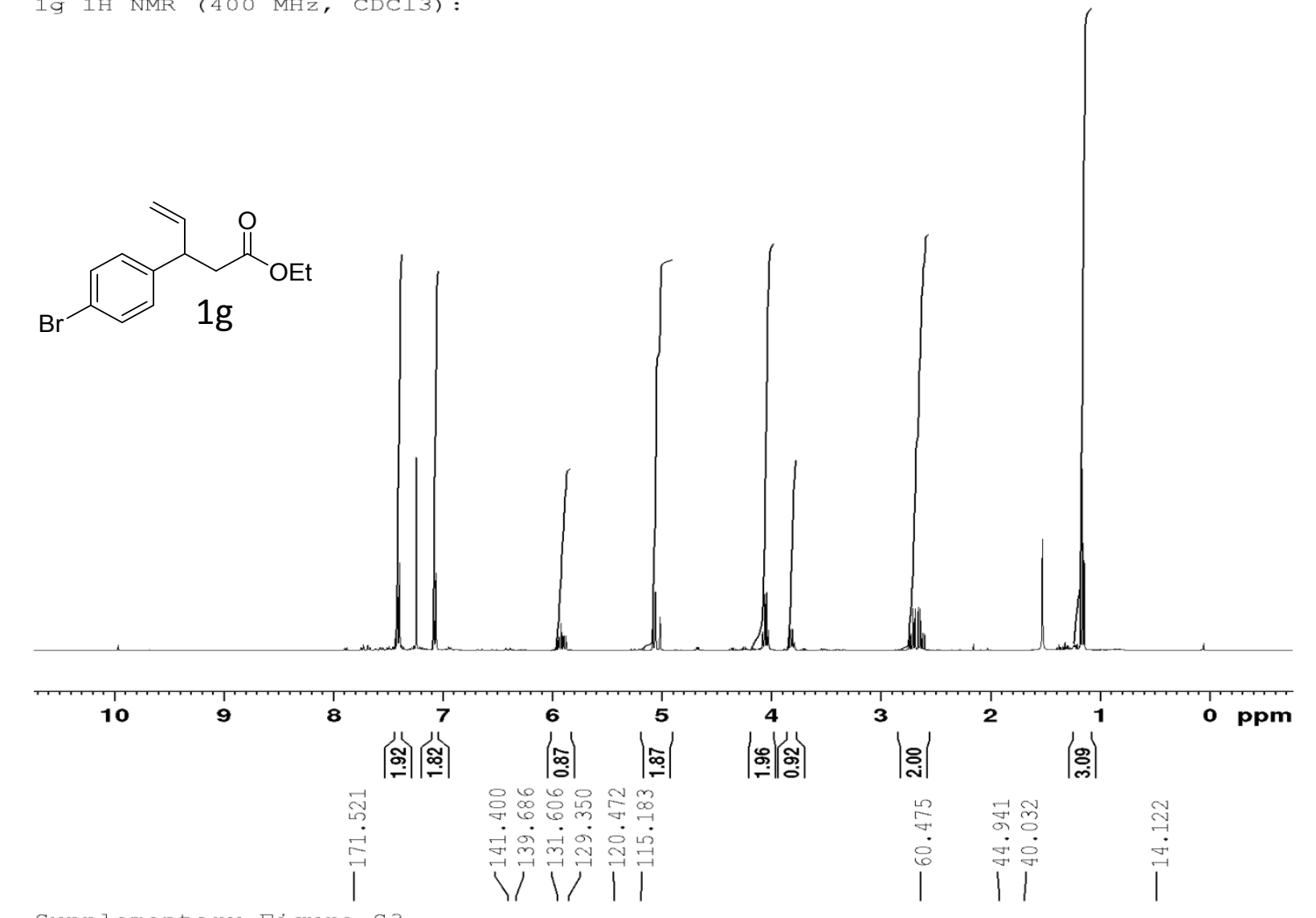

Supplementary Figure S3.
la 13 C NMR (101 MHz, CDC13):<smiles>C=CC(CC(=O)OCC)c1ccc(Br)cc1</smiles>

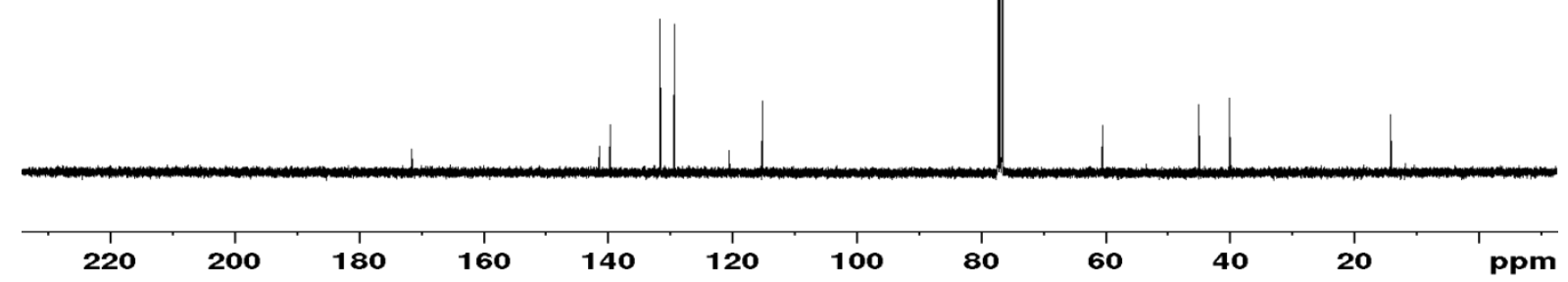




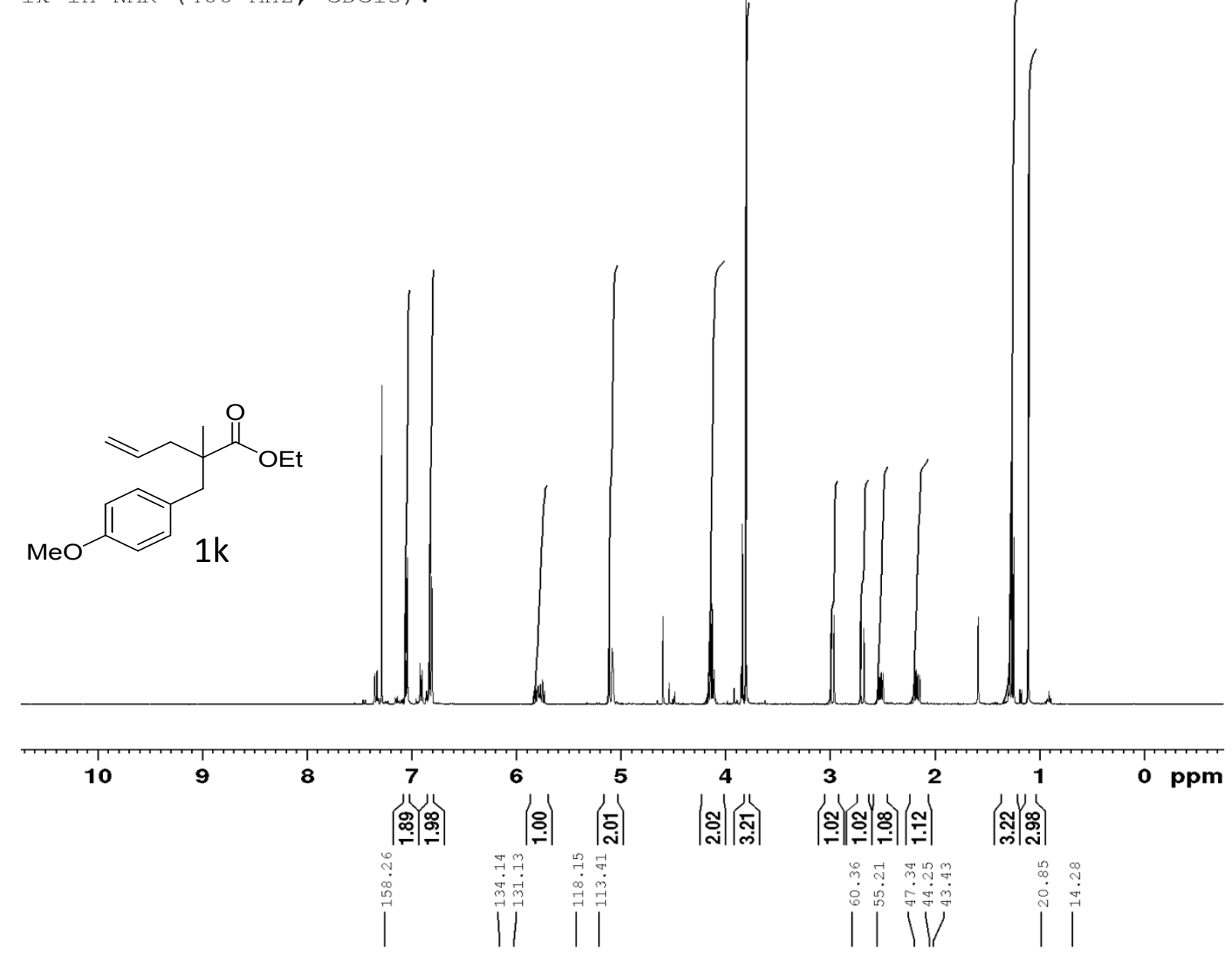

Supplementary Figure S2 .

1k 13C NMR (101 MHz, $\mathrm{CDCl} 3)$ :<smiles>C=CCC(C)(Cc1ccc(OC)cc1)C(=O)OCC</smiles>

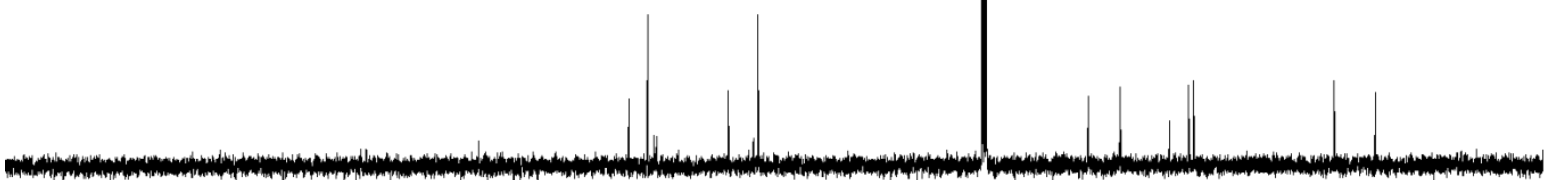

\begin{tabular}{llllllllllll}
\hline 220 & 200 & 180 & 160 & 140 & 120 & 100 & 80 & 60 & 40 & 20 & ppm
\end{tabular}


<smiles>C=CCC(C)(Cc1ccc(C(F)(F)F)cc1)C(=O)OCC</smiles>

11
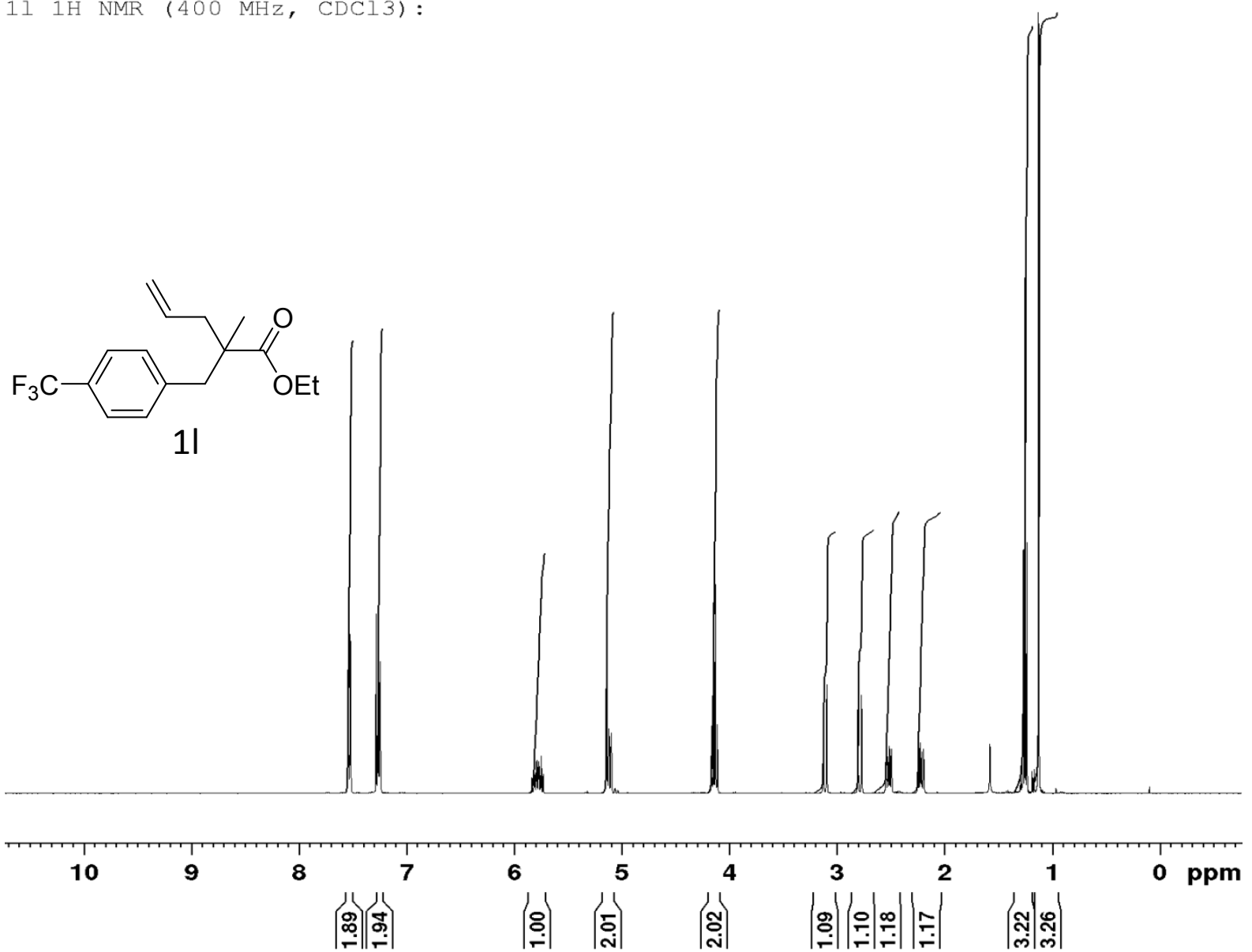

6

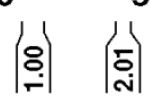

(ั)

3

\section{2}

1

0 ppm

supplementary Figure S3.

11 13C NMR (101 MHz, CDCl3):<smiles>C=CCC(C)(Cc1ccc(C(F)(F)F)cc1)C(=O)OCC</smiles>

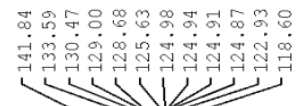

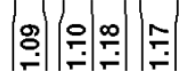

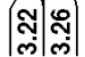

$\mid$
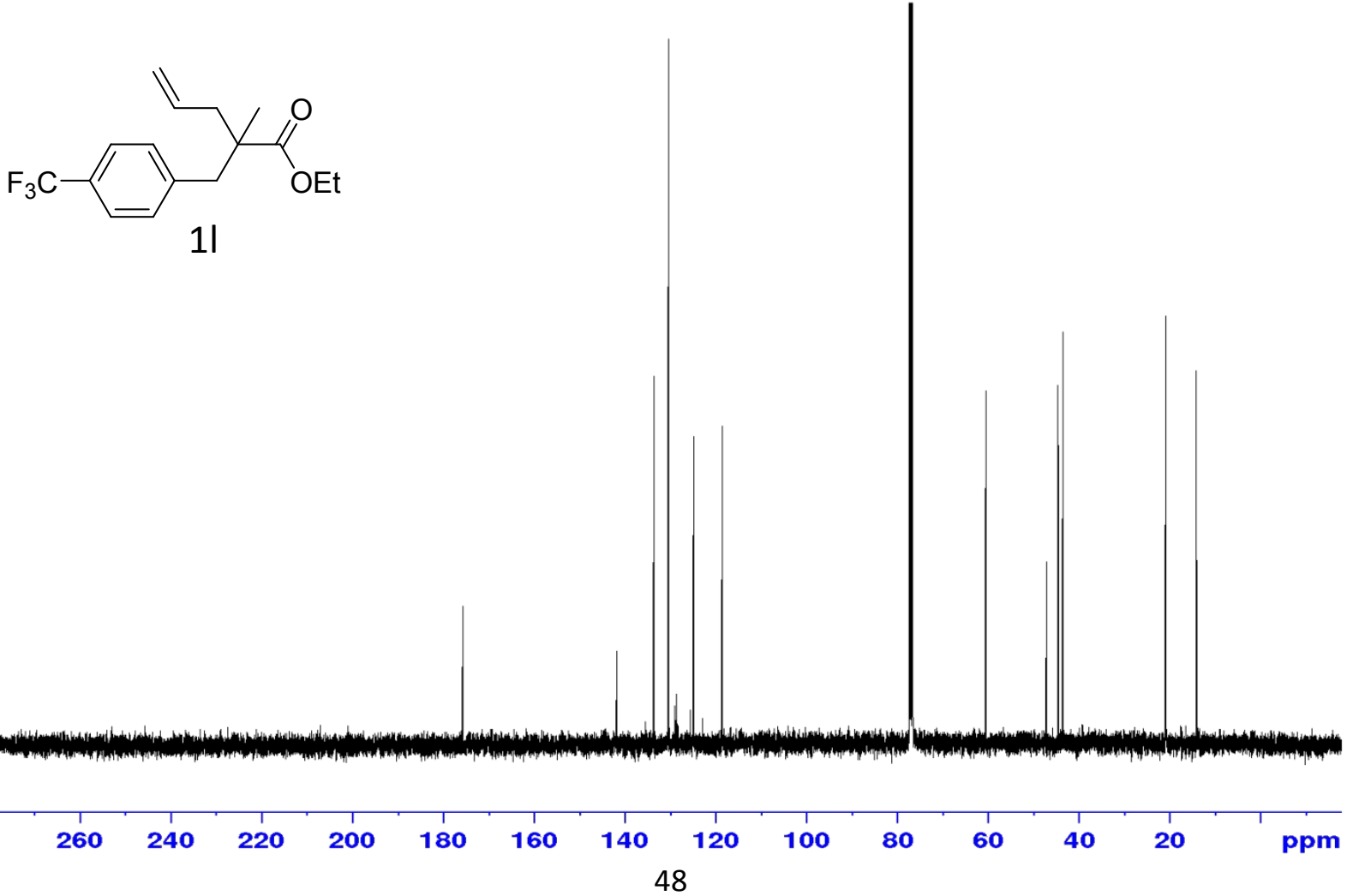
Supplementary Figure S3.

$1119 \mathrm{~F}$ NMR (377 $\mathrm{MHz}, \mathrm{CDCl} 3)$ :

म<smiles>C=CCC(C)(Cc1ccc(C(F)(F)F)cc1)C(=O)OCC</smiles>

ppm 


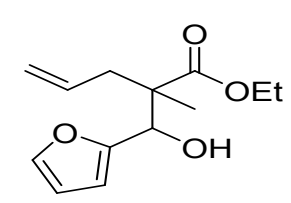

8
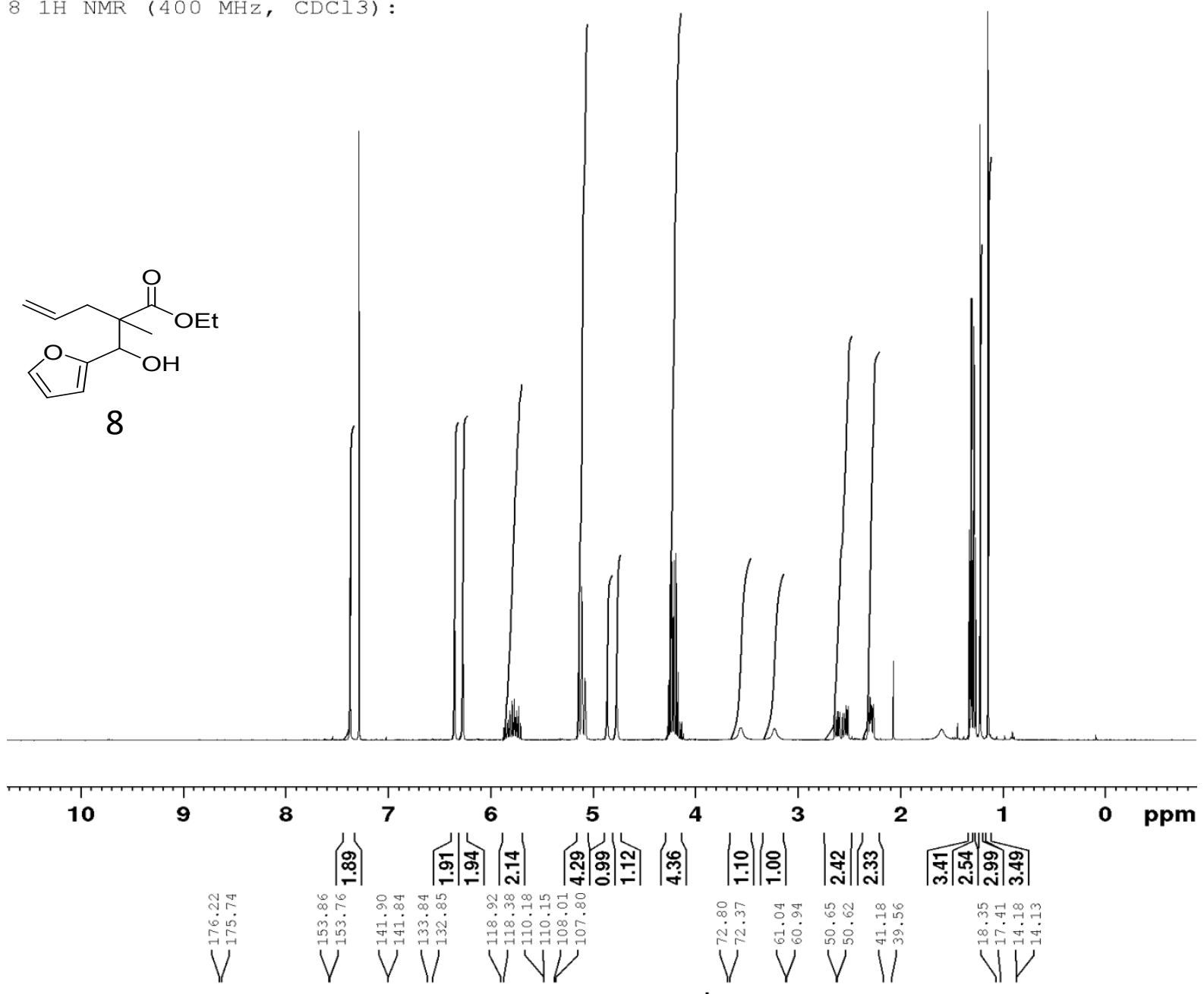

Supplementary Figure S4.

8 13C NMR (151 MHz, CDCi3):<smiles>C=CCC(CC=C)(C(=O)OCC)C(O)c1ccco1</smiles>

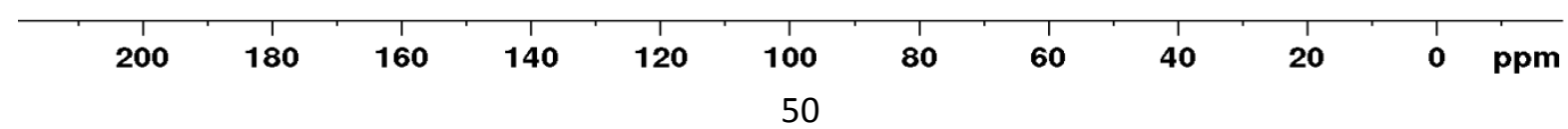


<smiles>C=CCC(CC=C)(C(=O)OCC)C(OC)c1ccco1</smiles>

$1 \mathrm{~m}$
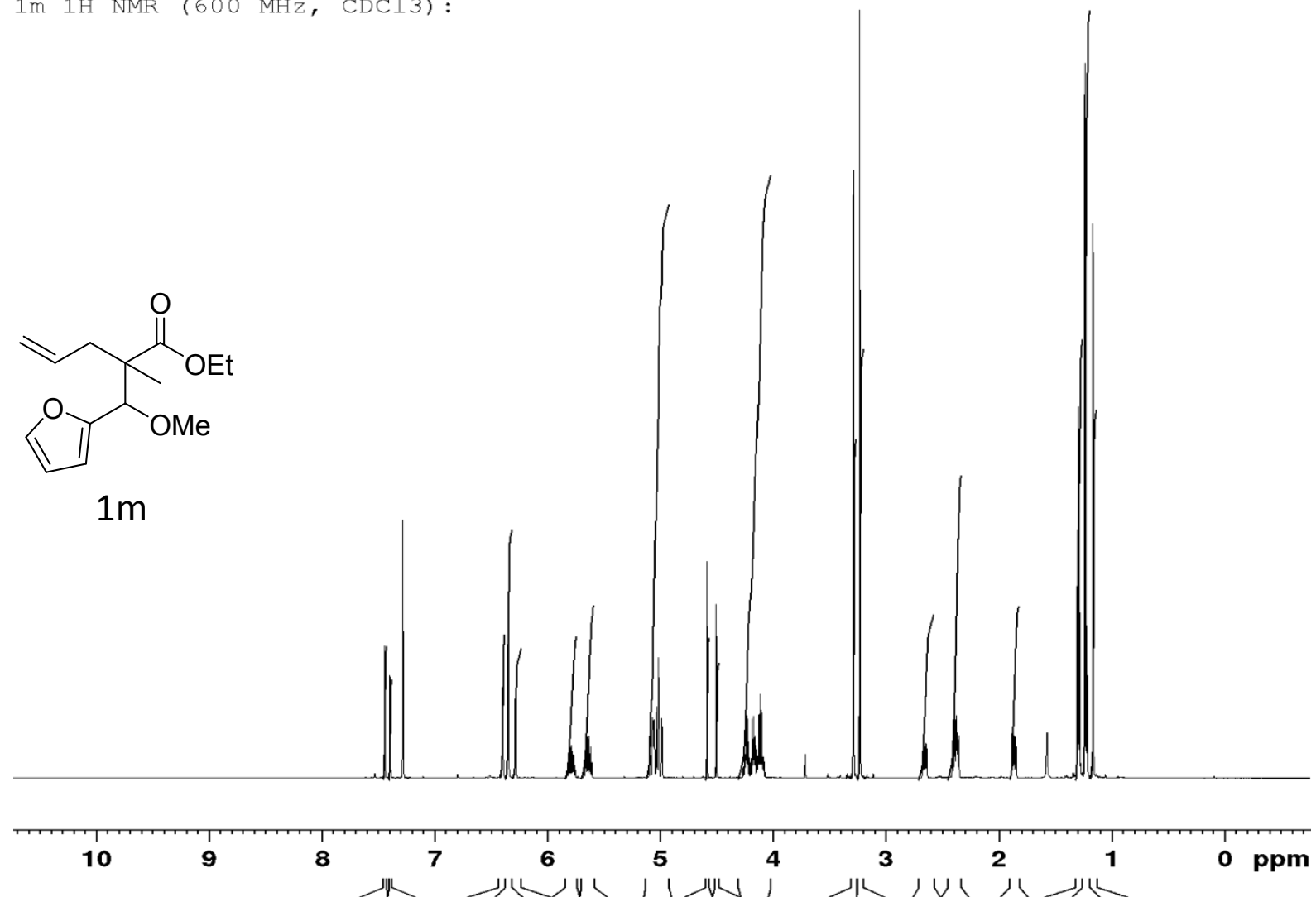

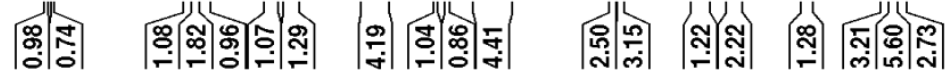

Supplementary Figure S5. $1 \mathrm{~m} \mathrm{13C} \mathrm{NMR} \mathrm{(151} \mathrm{MHz,} \mathrm{CDCl3):}$

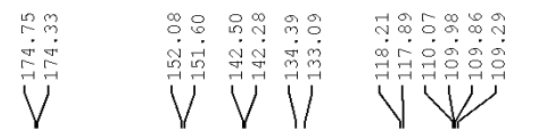<smiles>C=CCC(C)(C(=O)OCC)C(OC)c1ccco1</smiles>

$1 \mathrm{~m}$ 
B) NMR Spectra of Thioesters

Supplementary Figure S6.

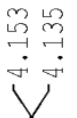

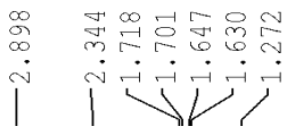

$\overbrace{2 a}^{O H C S t}$

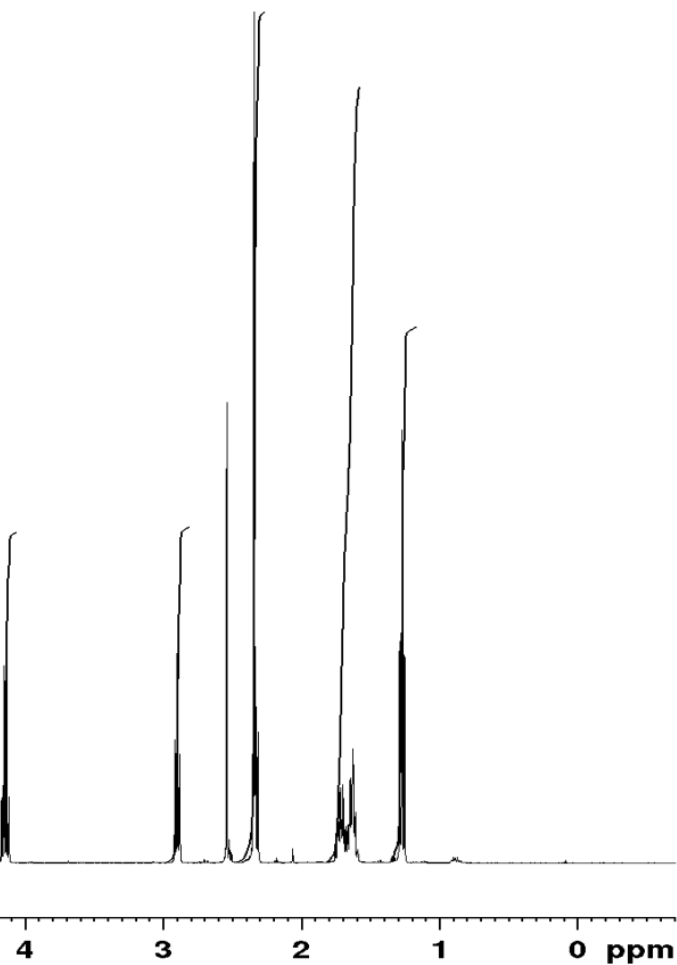

10

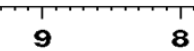

(워|

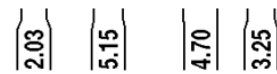

Supplementary Figure S6.

$2 a$ 13C NMR (101 MHz, CDC13).

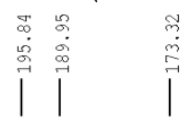<smiles>CCOC(=O)CCCC[As]</smiles>

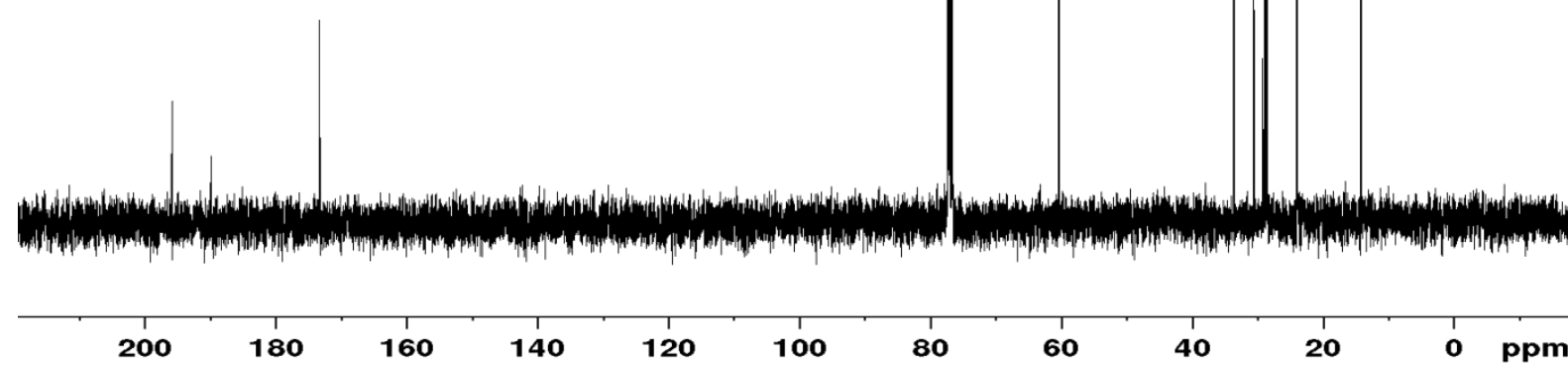


$\mathrm{AcS}_{\mathrm{CO}_{2} \mathrm{Et}}$

$2 b$

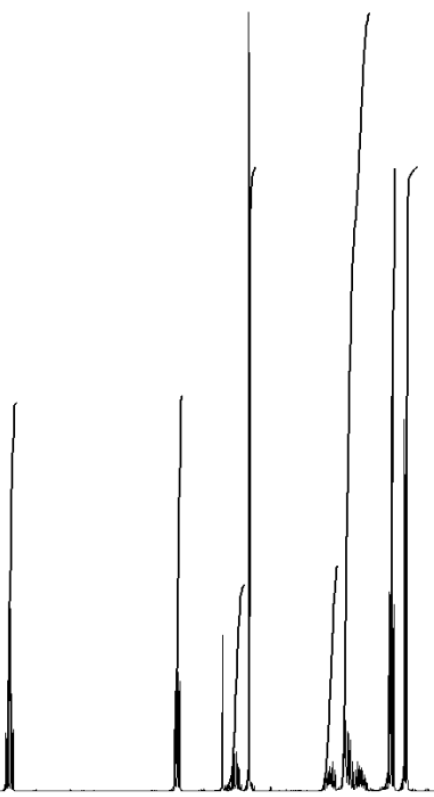

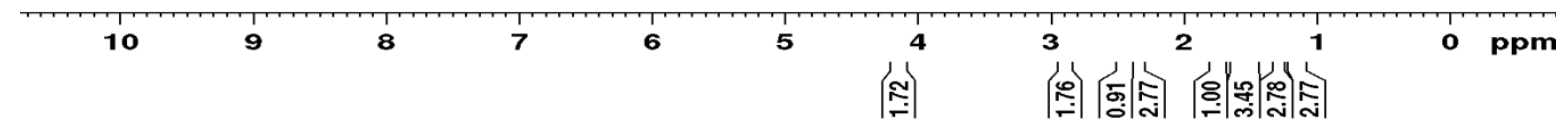

Supplementary Figure S7.

2b 13C NMR (101 MHz, CDCl3):

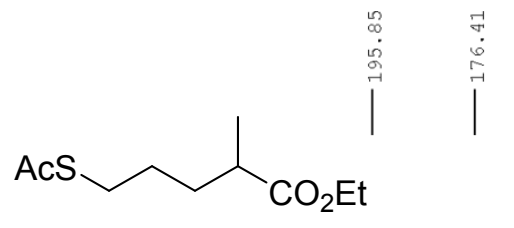

$2 b$

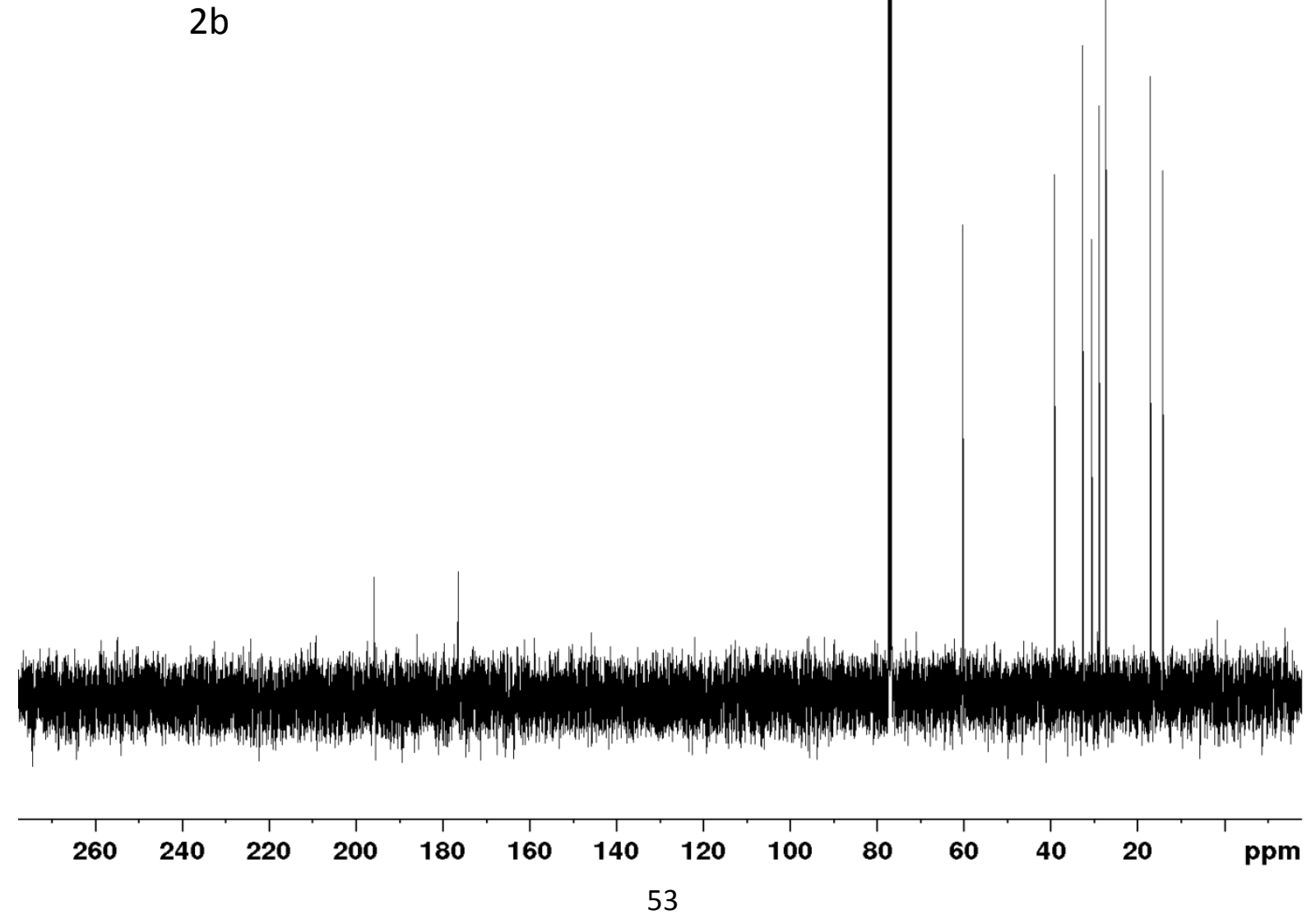




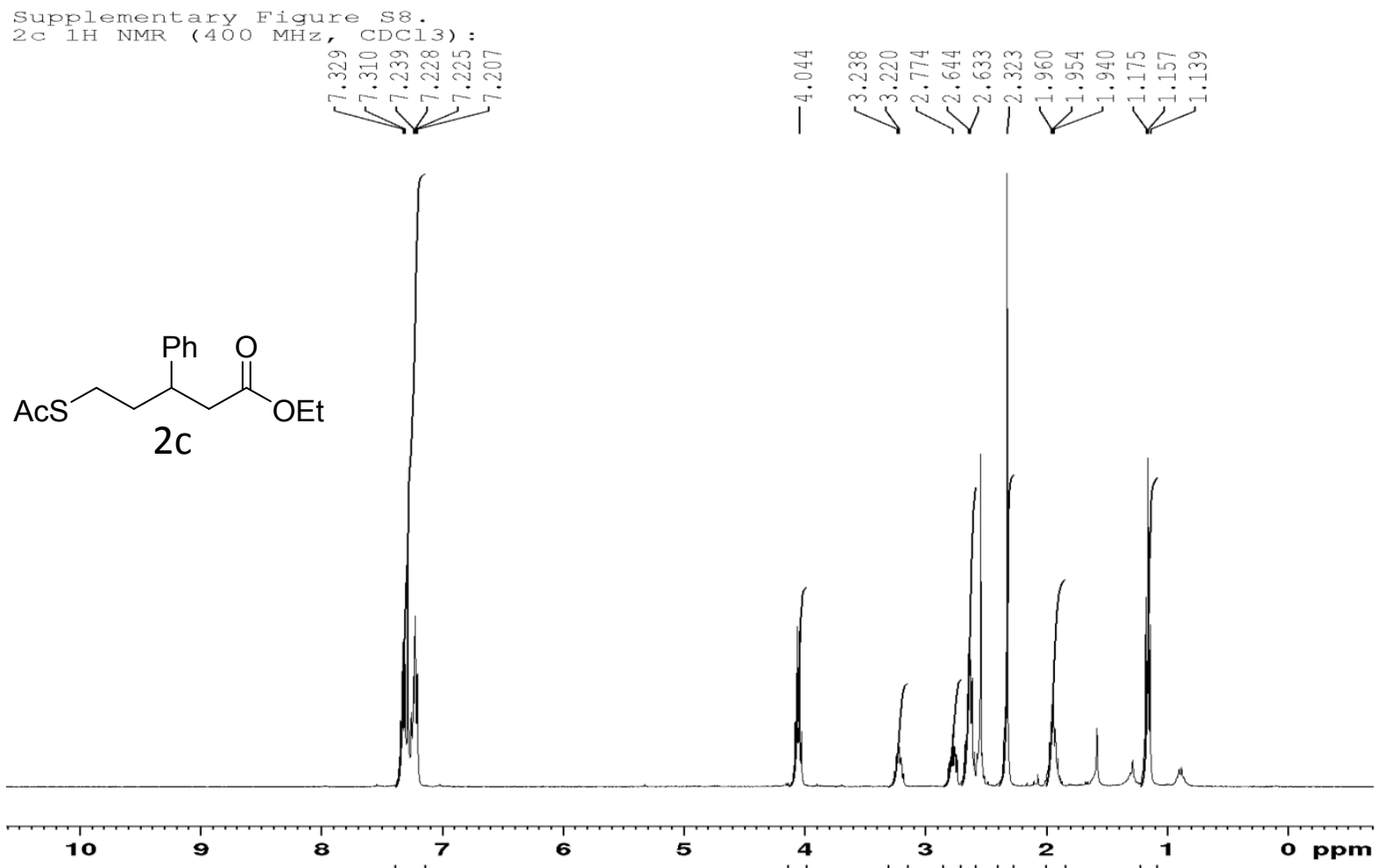

Supplementary Figure $\mathrm{S} 8$

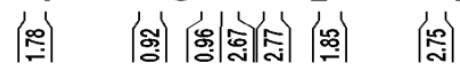

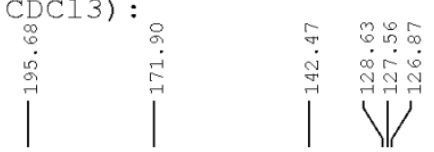

$\overbrace{2 \mathrm{C}}^{\mathrm{Ph}} \overbrace{\mathrm{OEt}}^{\mathrm{O}}$

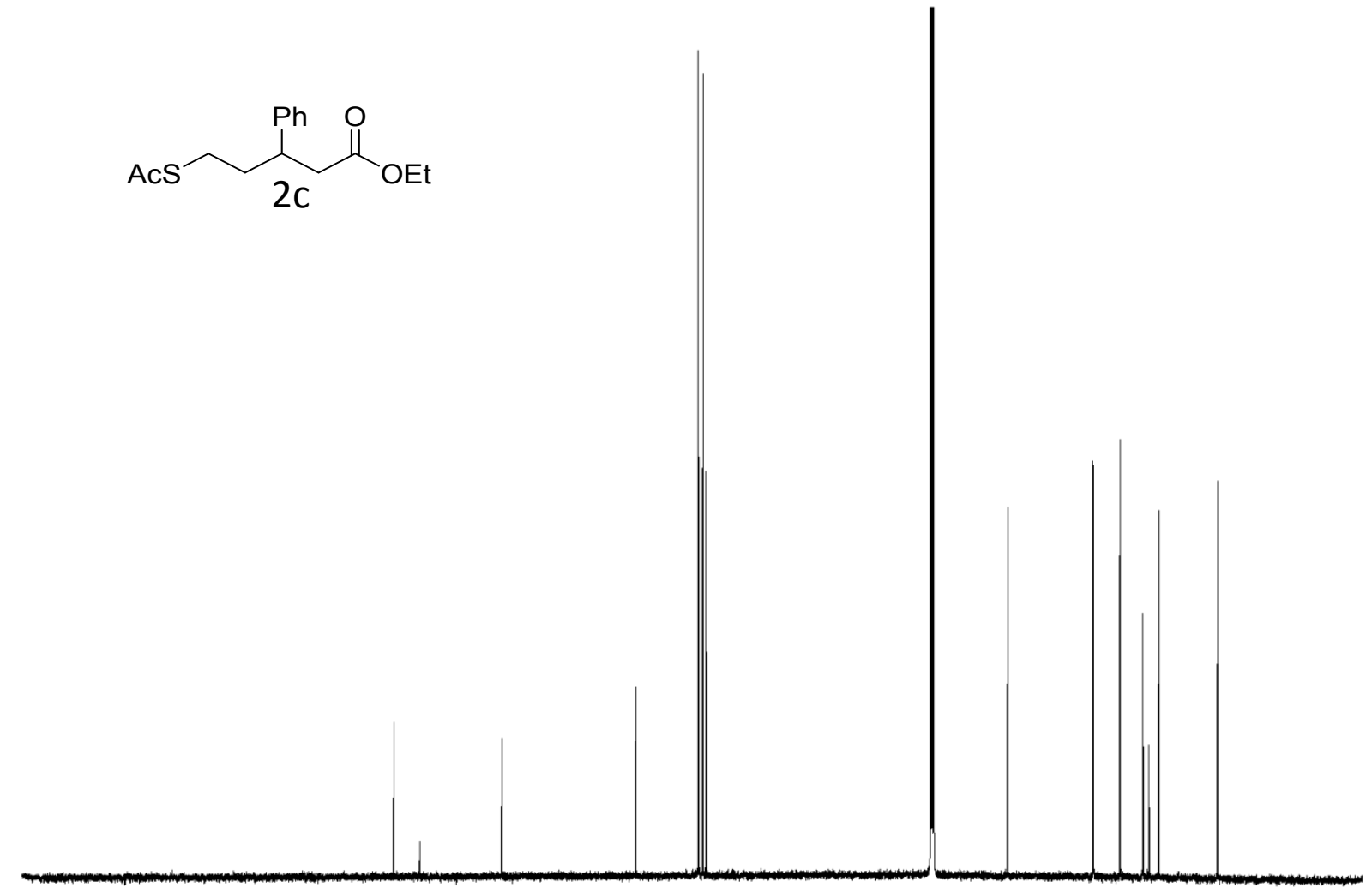

$\left.\operatorname{lil}^{4}\right|^{1}$

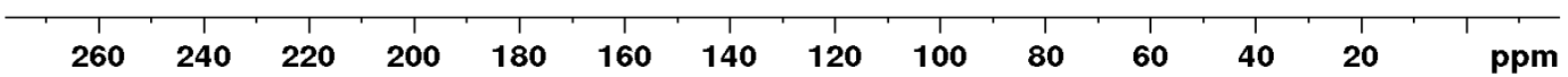




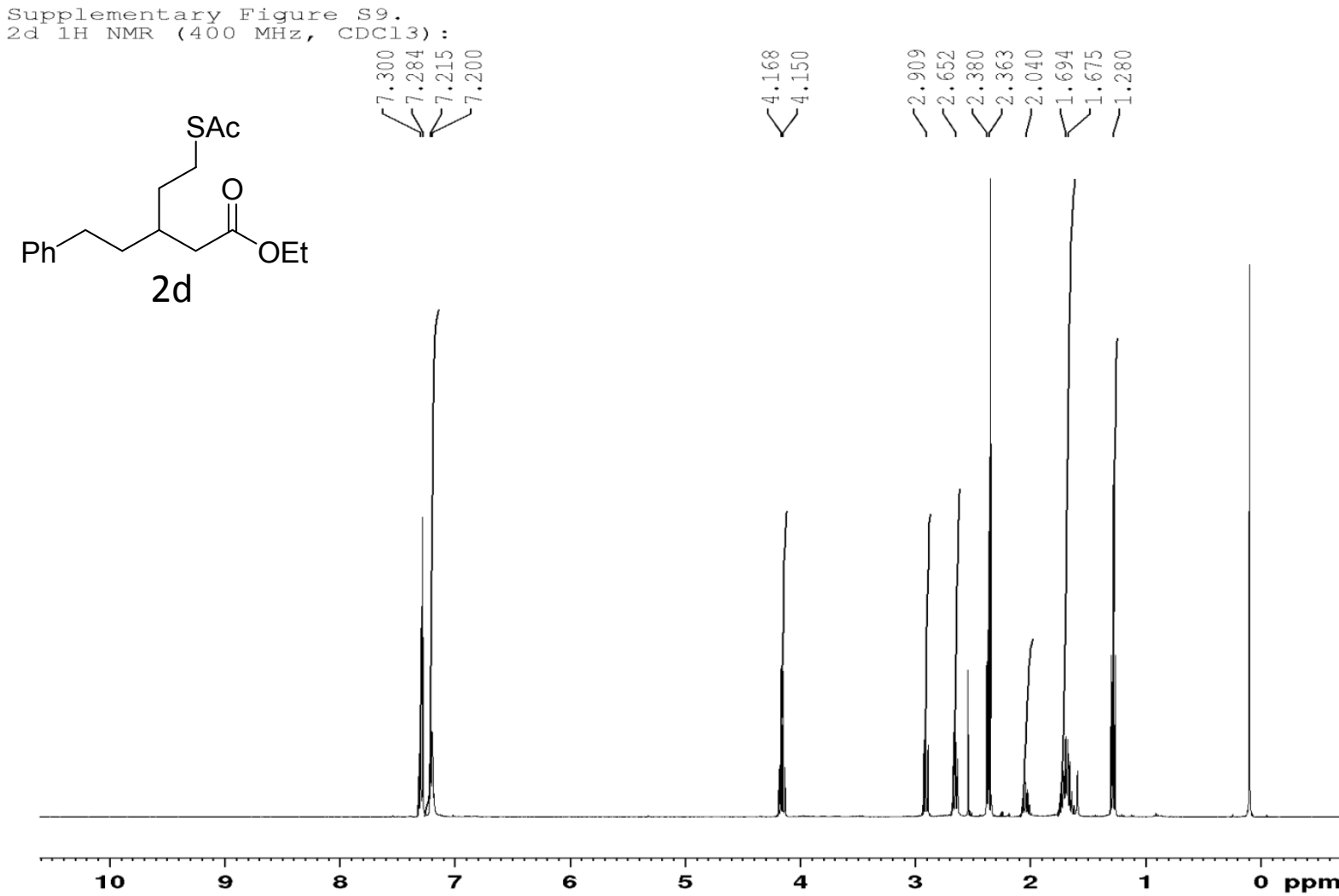

同跑

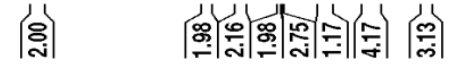

Supplementary Figure S9.

2d 13C NMR (101 MHz, CDC13):
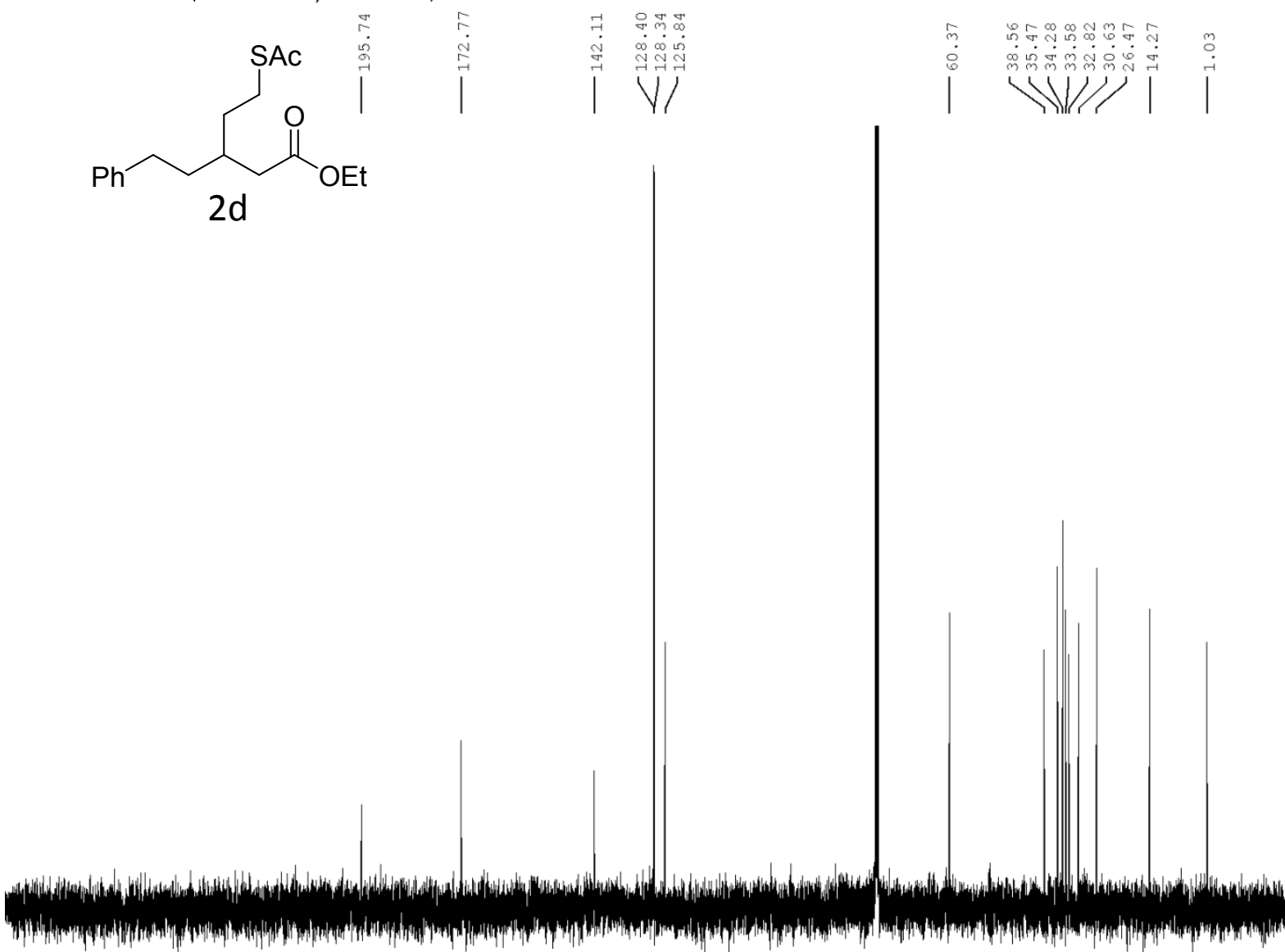

260240
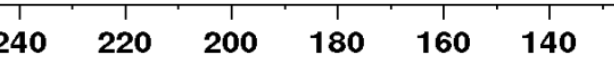
<smiles>CCOC(=O)CC(CCS(C)(=O)=O)c1ccc(F)cc1</smiles>

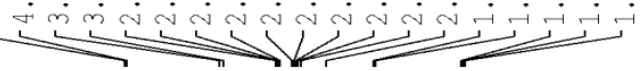

$F \quad 2 e$
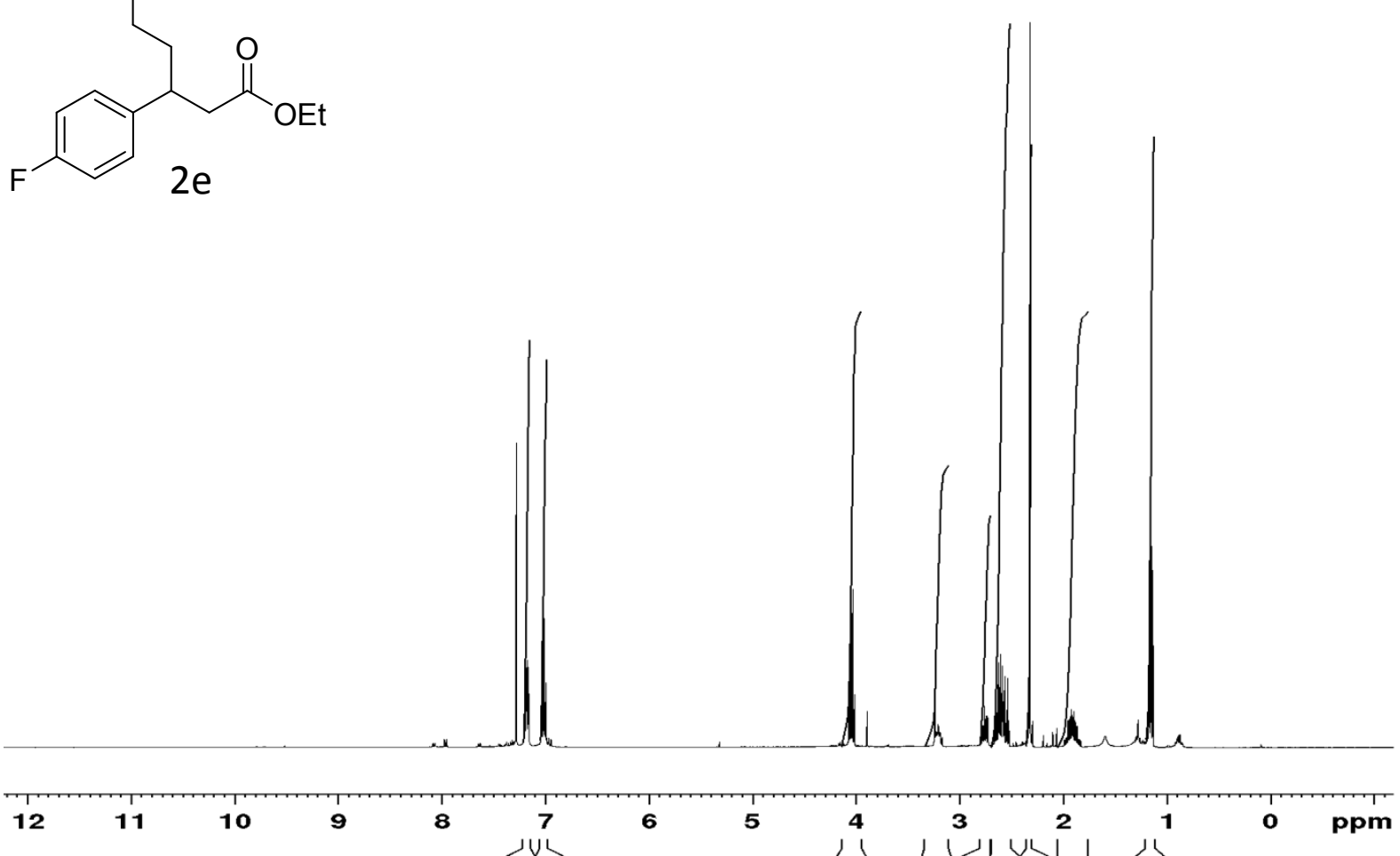

空

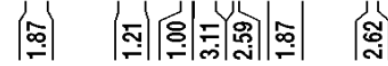

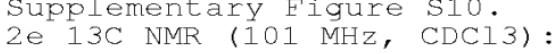

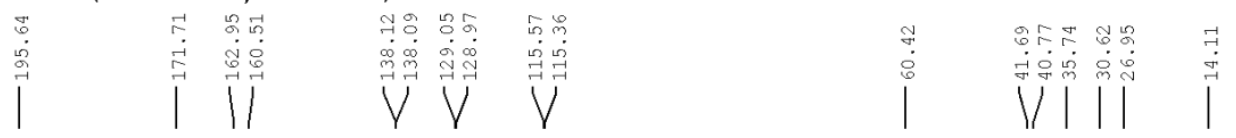<smiles>CCOC(=O)CC(CCS(C)(=O)=O)c1ccc(F)cc1</smiles>
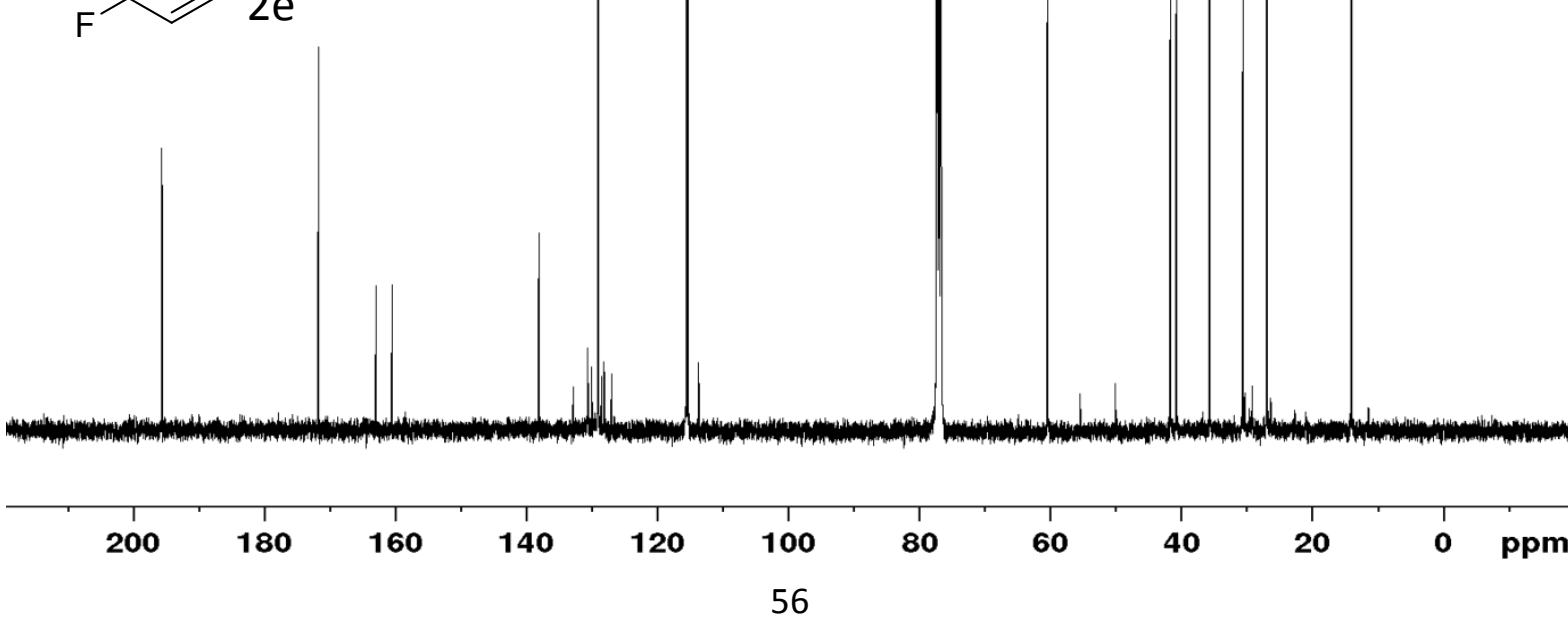
<smiles>CCOC(=O)CC(CCS(C)(=O)=O)c1ccc(F)cc1</smiles>

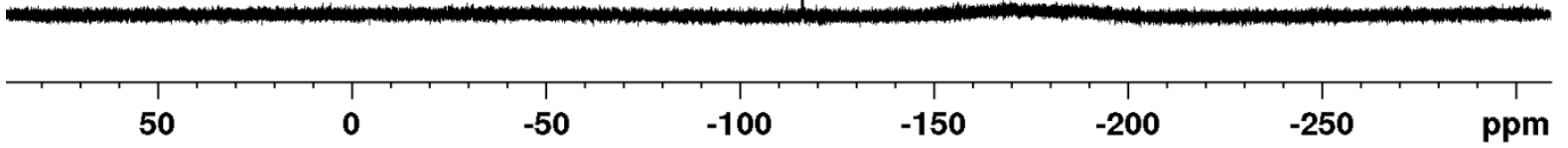


<smiles>CCOC(=O)CC(CC[Se])c1ccc(Cl)cc1</smiles>

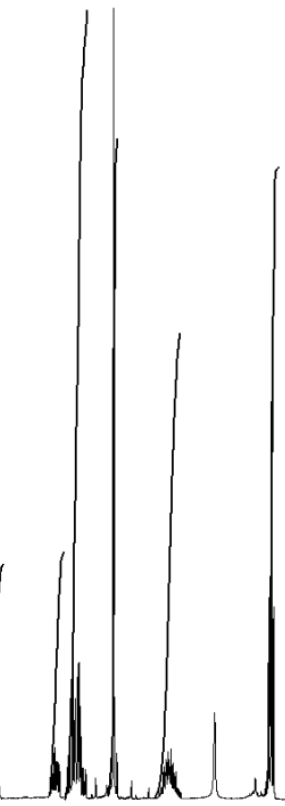

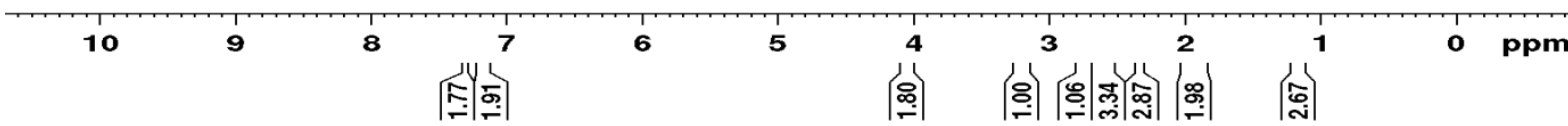

Supplementary Figure S11.

2 f $13 \mathrm{C} \mathrm{NMR} \mathrm{(101} \mathrm{MHz,} \mathrm{CDCl3):}$

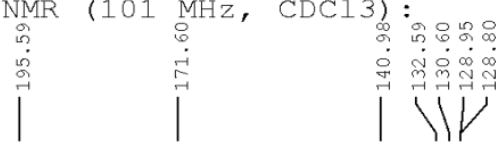

$\mid$<smiles>CCOC(=O)CC(CC[AsH3])c1ccc(Cl)cc1</smiles>
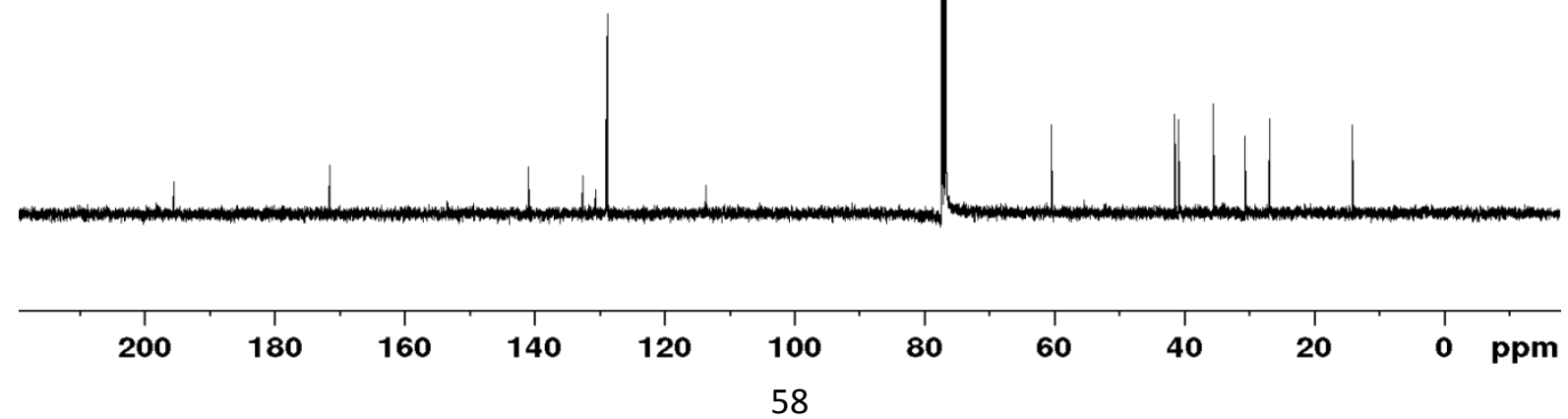
<smiles>CCOC(=O)CC(CCS(C)(=O)=O)c1ccc(Br)cc1</smiles>

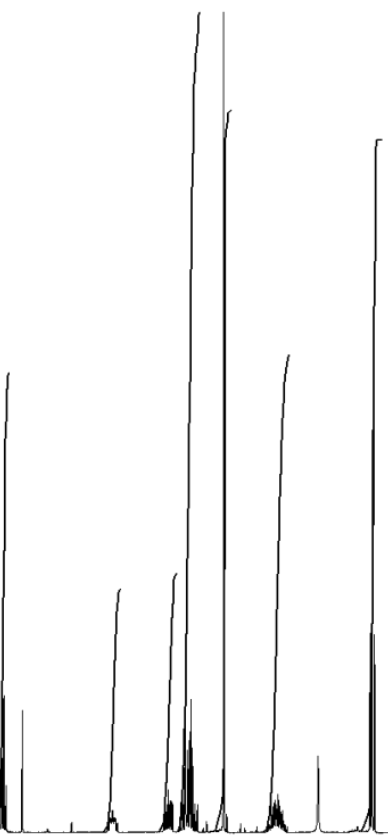

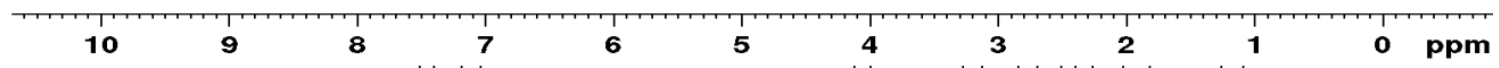

Supplementary Figure S12.

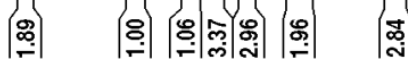

$2 \mathrm{~g}$ 13C NMR (101 MHz, CDCl3):
|
|
$\mid$<smiles>CCOC(=O)CC(CCS(C)(=O)=O)c1ccc(Br)cc1</smiles>
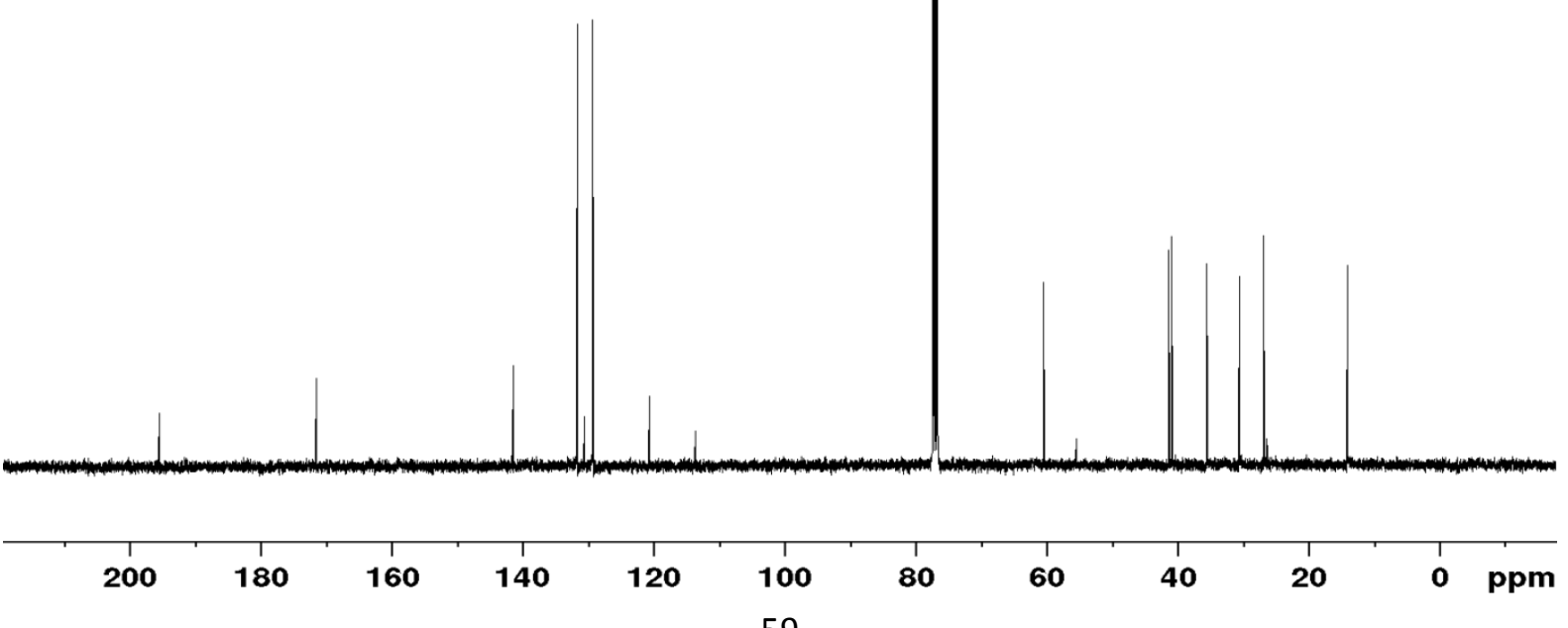


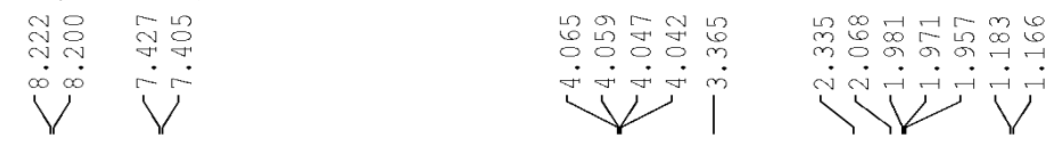

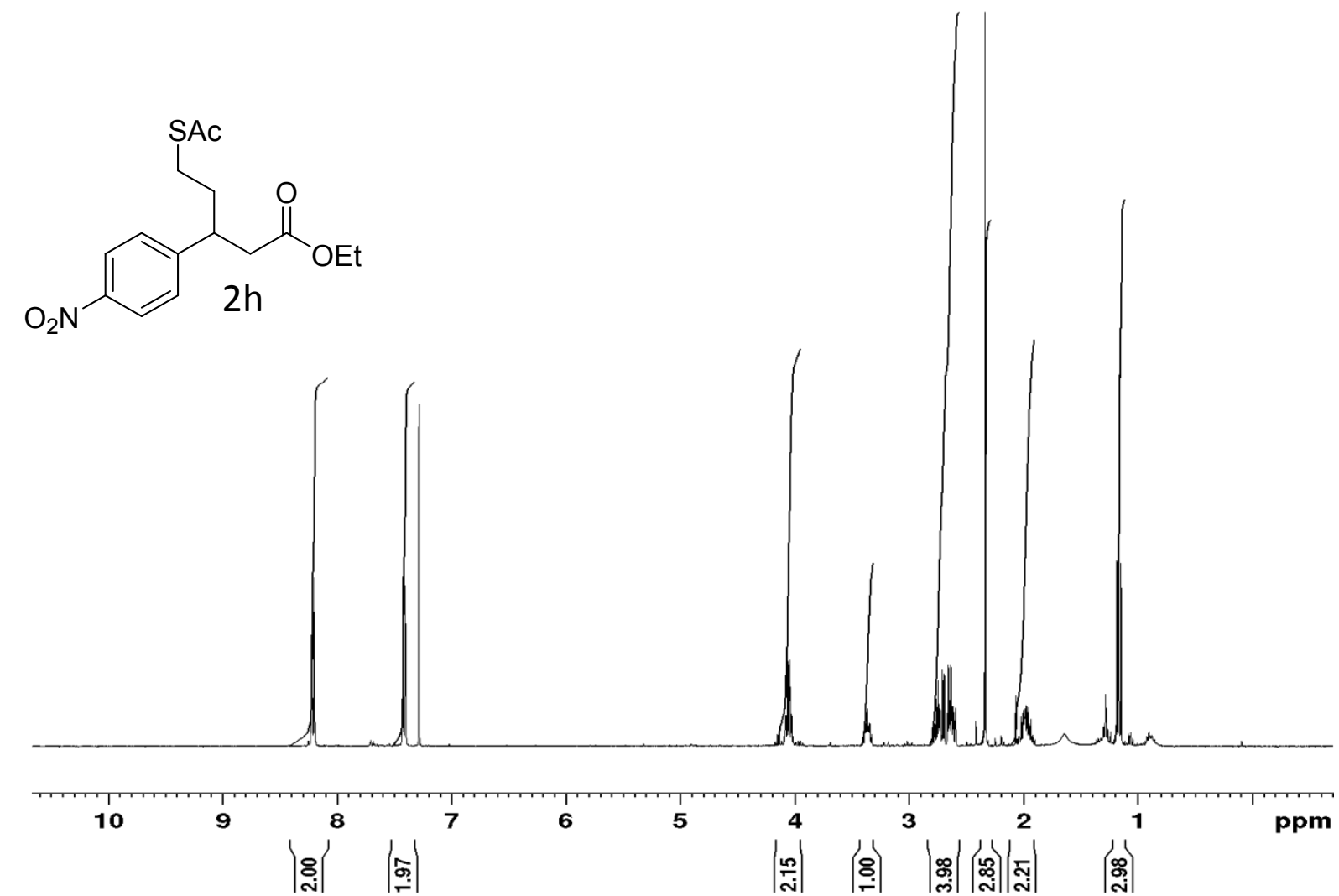

Supplementary Figure S13.

$2 \mathrm{~h} 13 \mathrm{C}$ NMR (101 MHz, CDCl3):

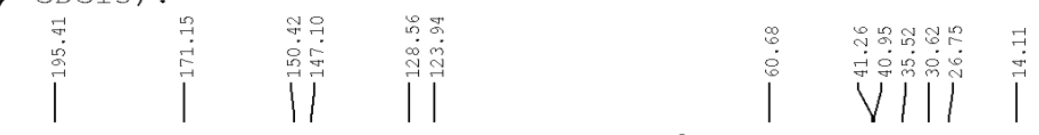

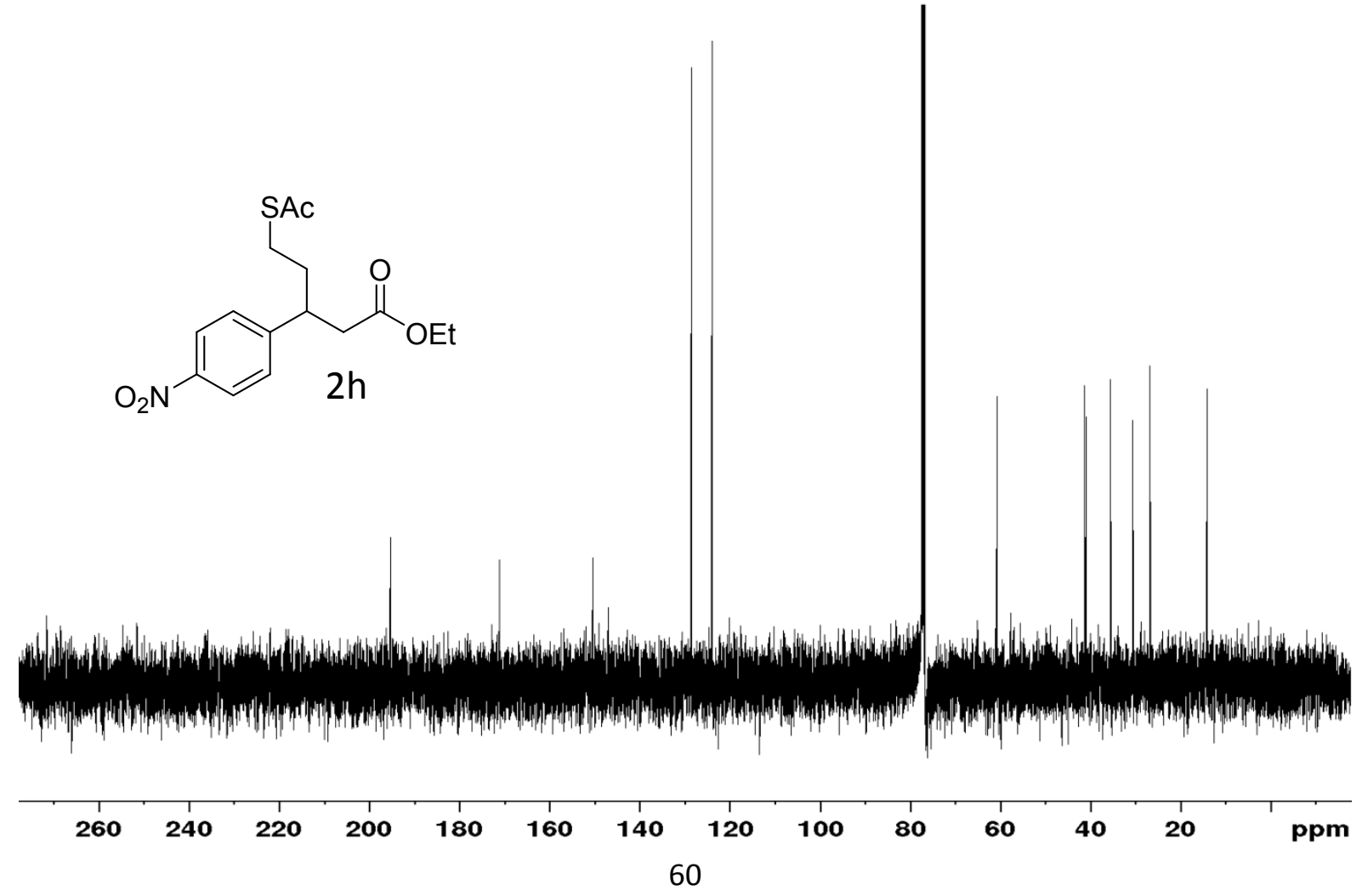


<smiles>[R][C@H](C)CCC(=O)OCC</smiles>
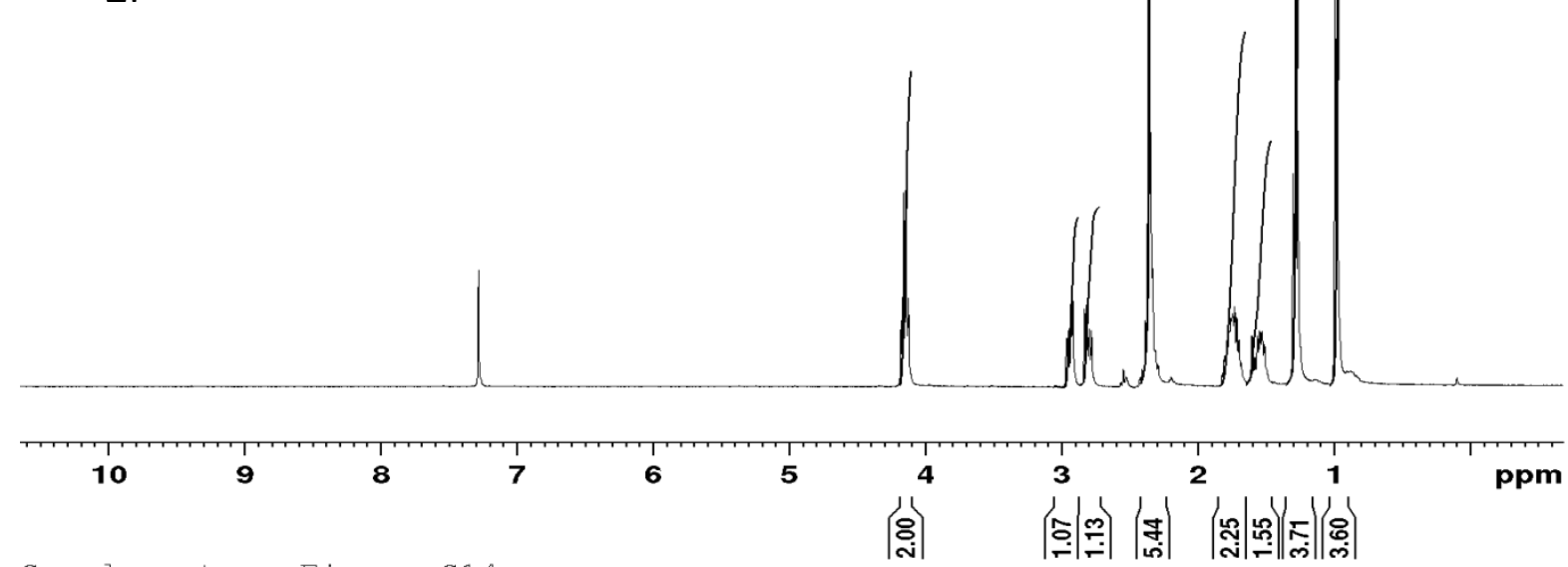

Supplementary Figure S14.

2i 13C NMR (101 MHz, CDC13):<smiles>[Z]C(CCC(=O)OCC)CC(C)C</smiles>
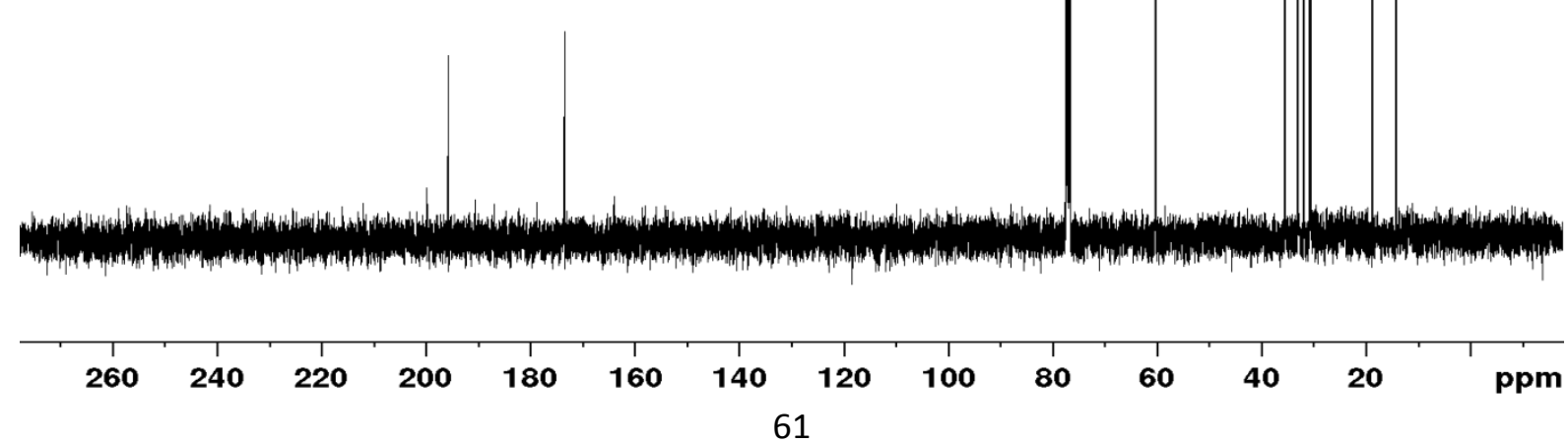


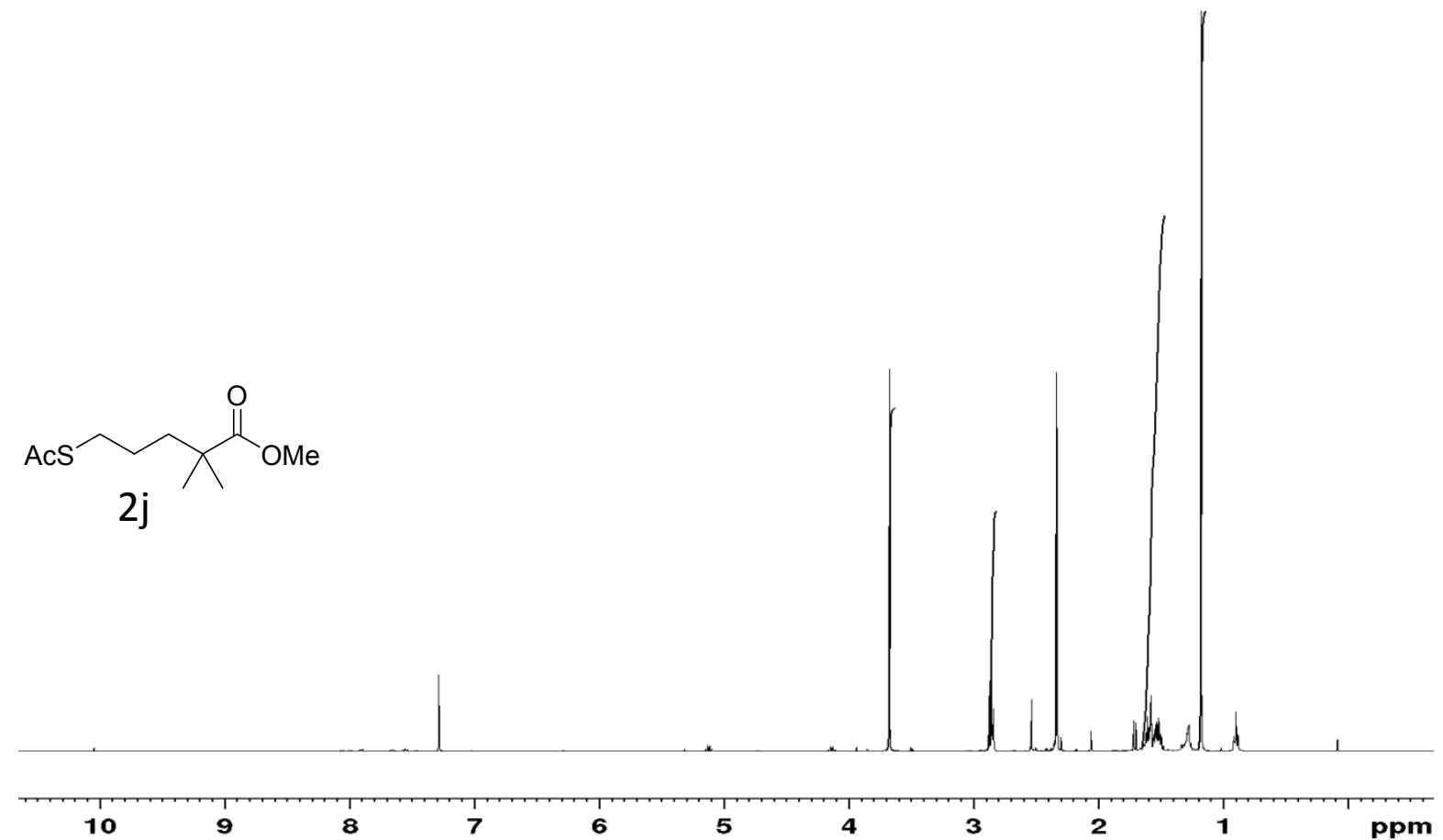

Supplementary Figure S15.

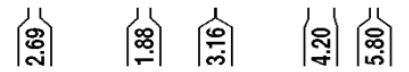

$2 j$ 13C NMR (101 MHz, CDCi3)
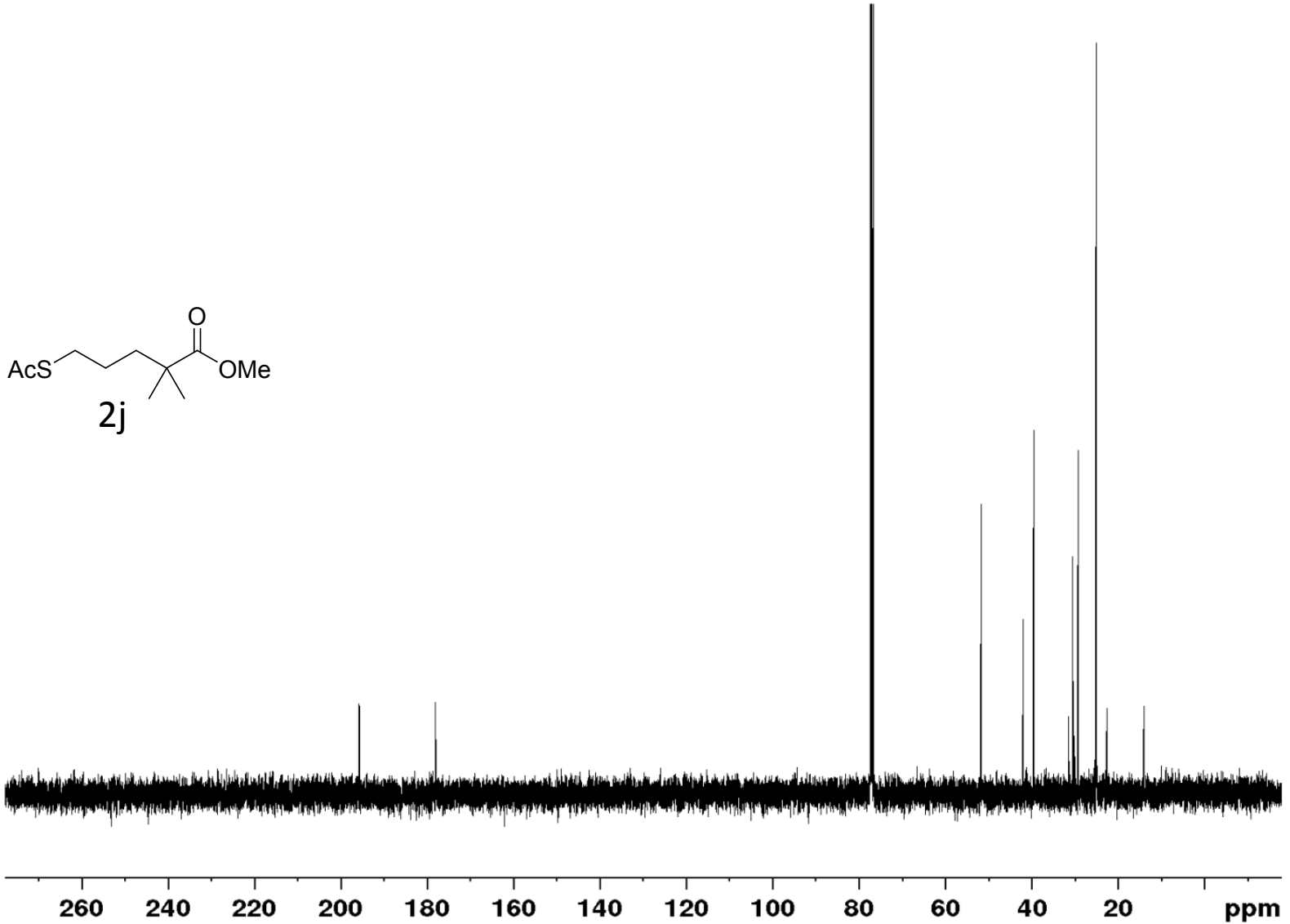


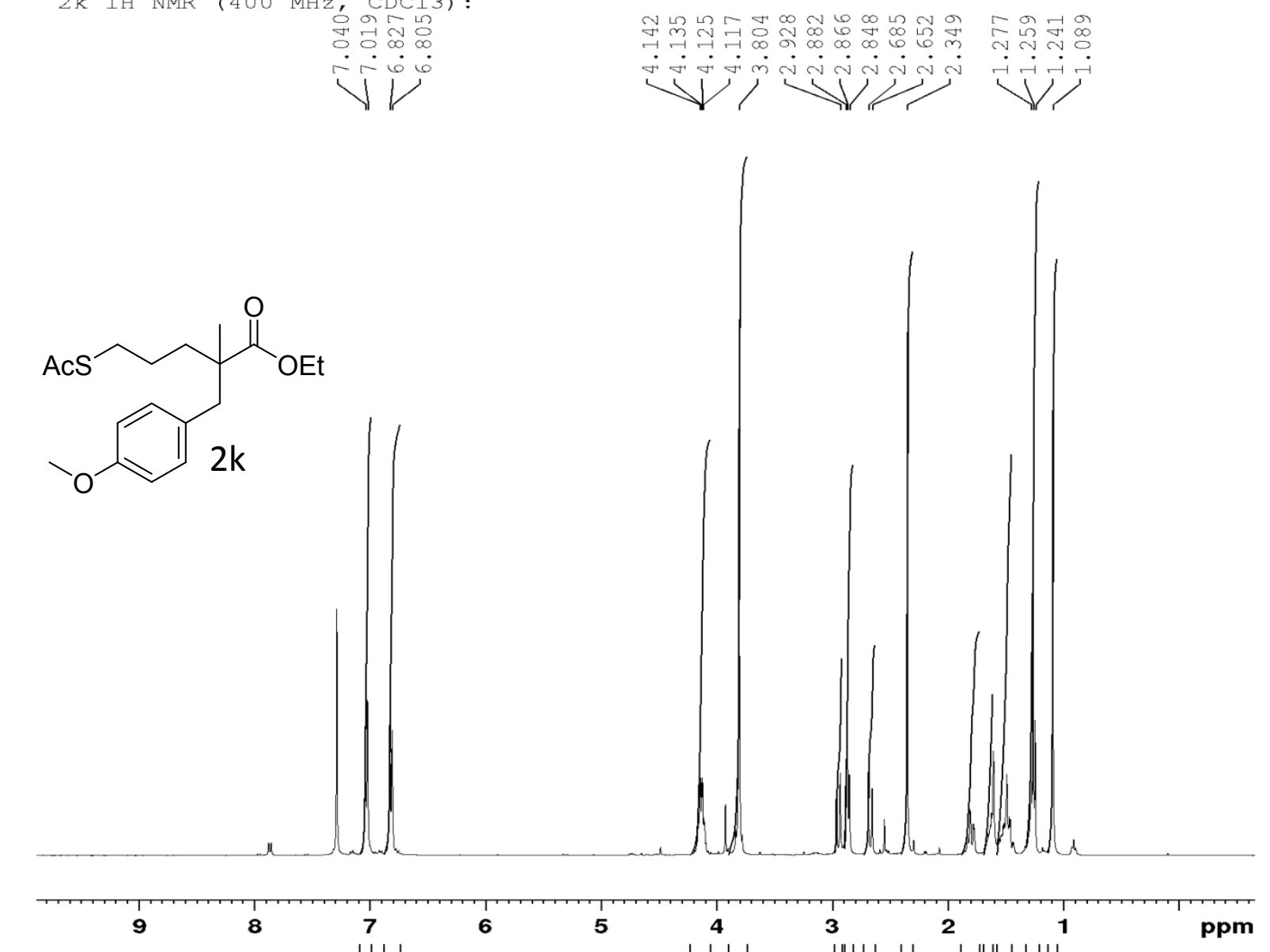

|ํํ이이

|

Supplementary Figure S16.
$2 \mathrm{k} 13 \mathrm{C}$ NMR (101 MHz, CDC13)

|<smiles>[X]c1ccc(OC)cc1CC(C)(CCCS(C)(F)F)C(=O)OCC</smiles> 
<smiles>CCOC(=O)C(C)(CCCSC(F)(F)F)Cc1ccc(C(F)(F)F)cc1</smiles>

$\mathrm{F}_{3} \mathrm{C}^{-}$

ppm

Supplementary Figure S17.

21 13C NMR (101 MHz, CDCi3):

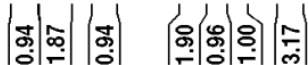
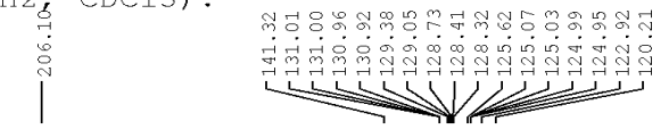

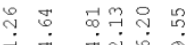

$\left.\left.\right|^{n}\right|^{m}$<smiles>[Z]CC(CCCSC(C)(F)F)(Cc1ccc(C(F)(F)F)cc1)C(=O)OCC</smiles>

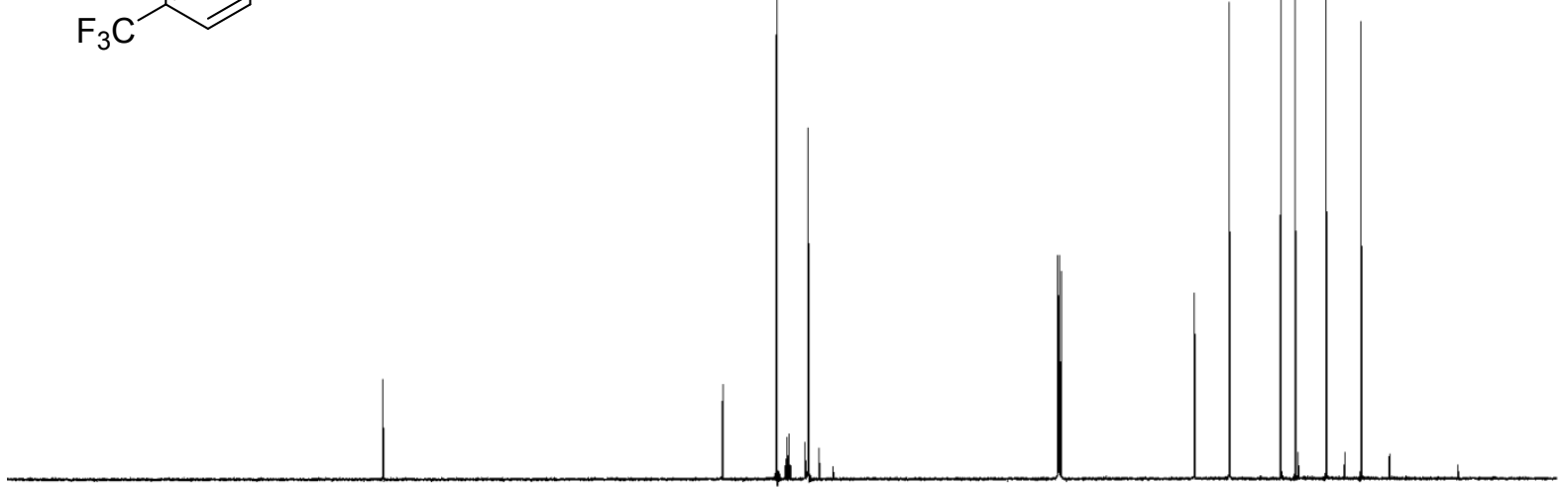


Supplementary Figure S17.

21 19F NMR (377 MHz, CDCl3):

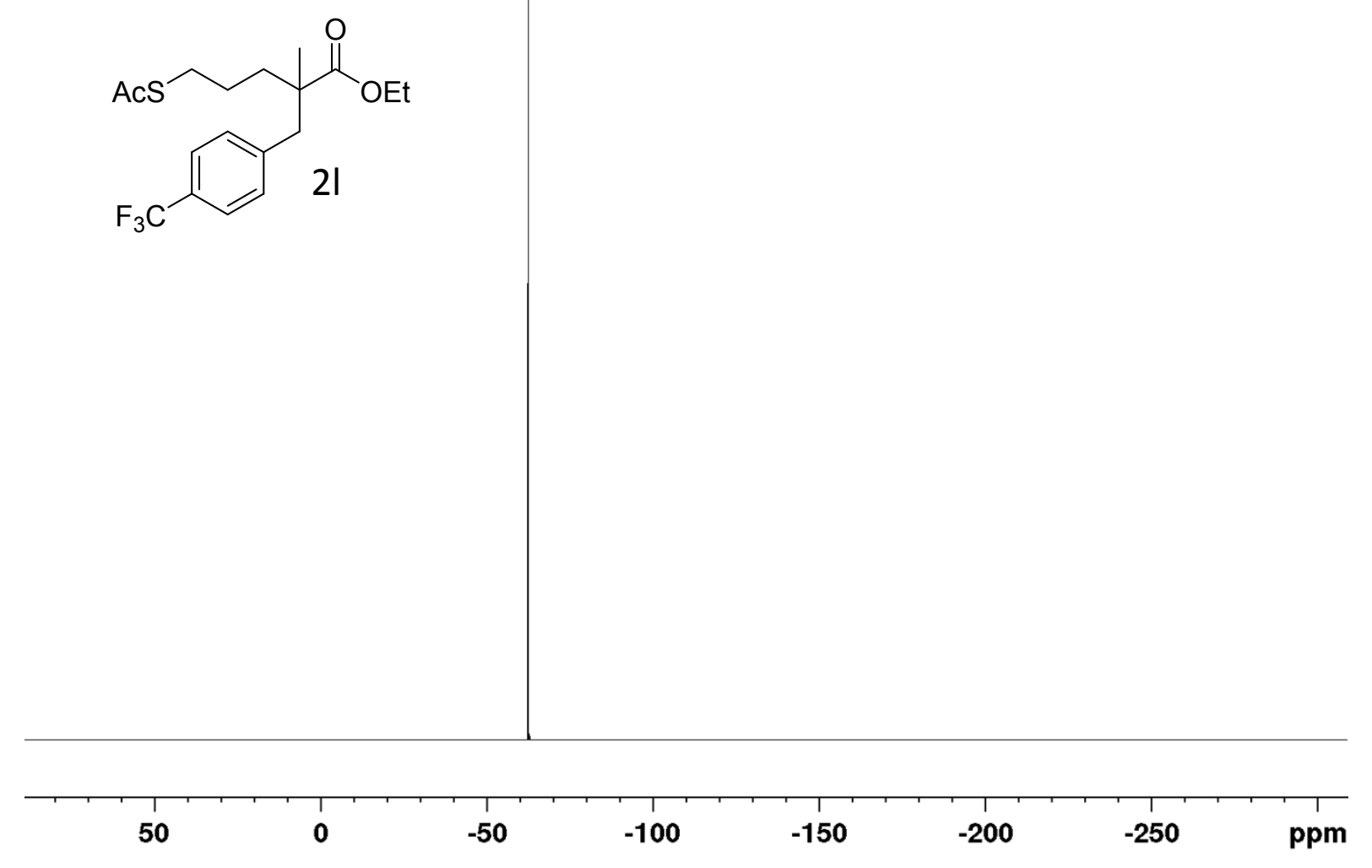


<smiles>CCOC(=O)C(C)(CCCSC(C)(F)F)C(OC)c1ccco1</smiles>
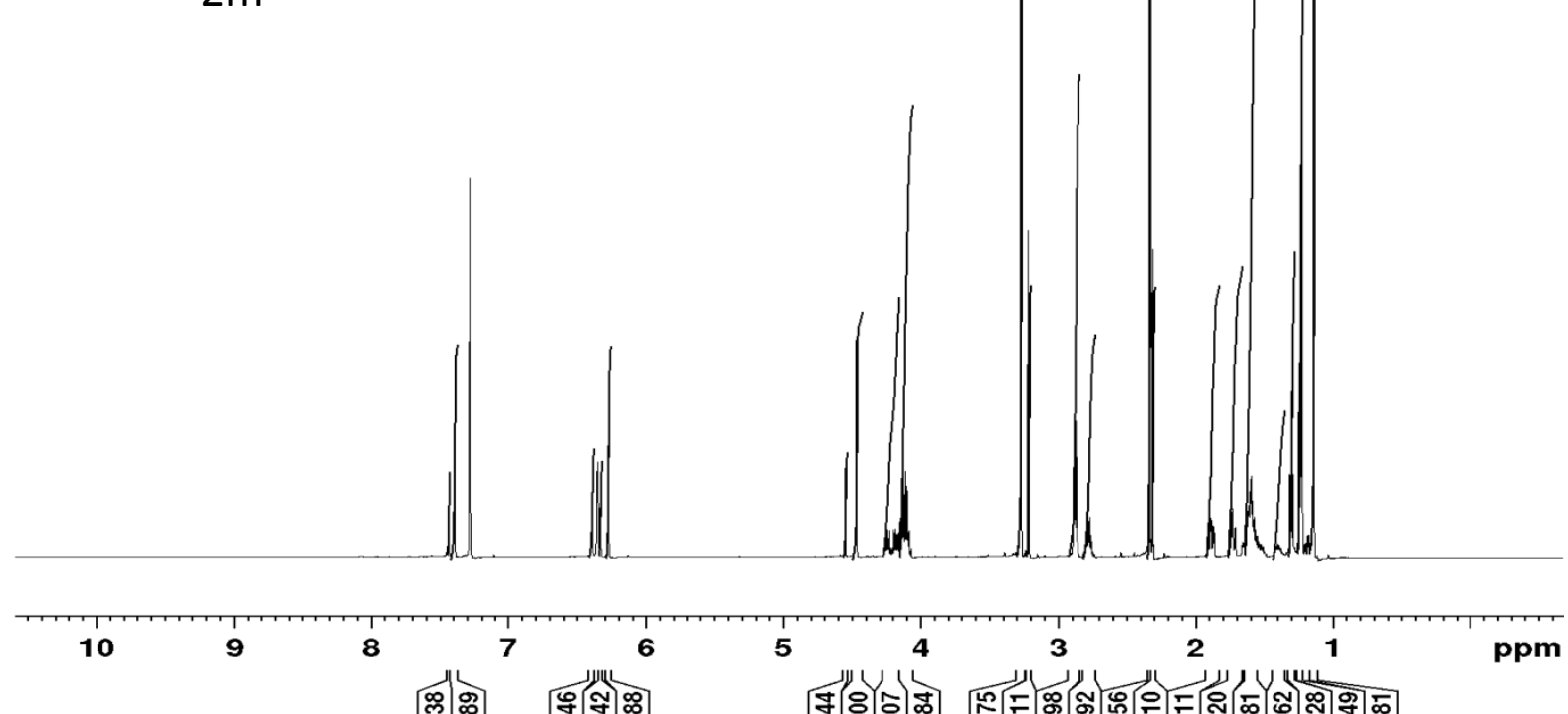
Supplementary Figure S18.
$2 \mathrm{~m}$ 13C NMR (101 MHz, CDC13):<smiles>CCOC(=O)C(C)(CCCS(C)(F)F)C(OC)c1ccco1</smiles>

\begin{tabular}{llllllllllll}
\hline 200 & 180 & 160 & 140 & 120 & 100 & 80 & 60 & 40 & 20 & 0 & ppm \\
& & & & & 66 & & & &
\end{tabular}




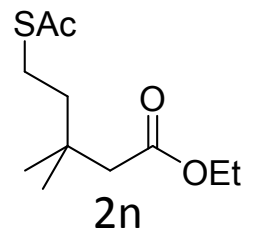

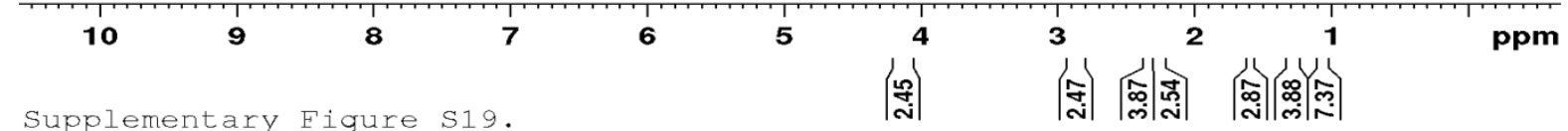

$2 \mathrm{n} 13 \mathrm{C}$ NMR (101 MHz, CDCi3):
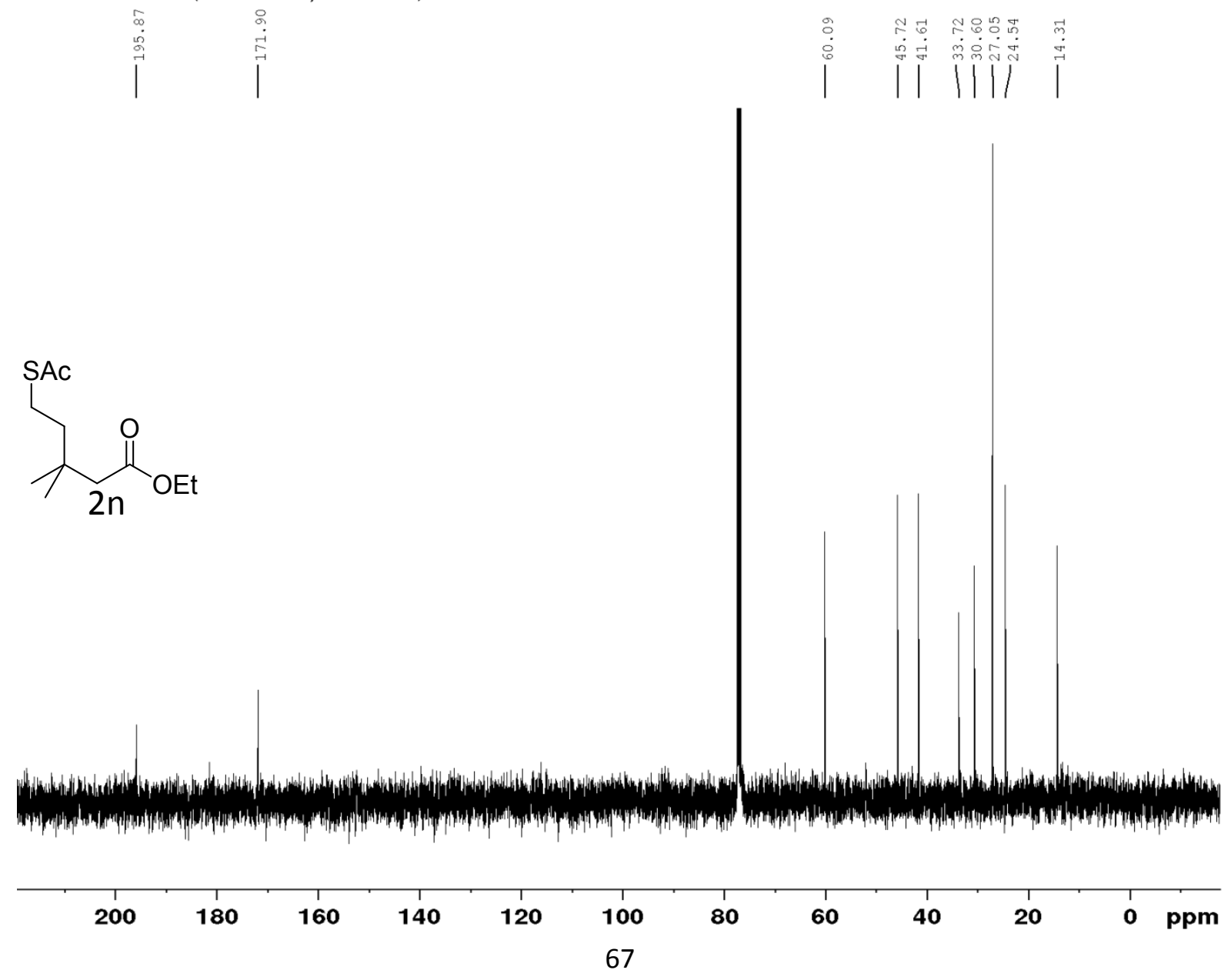

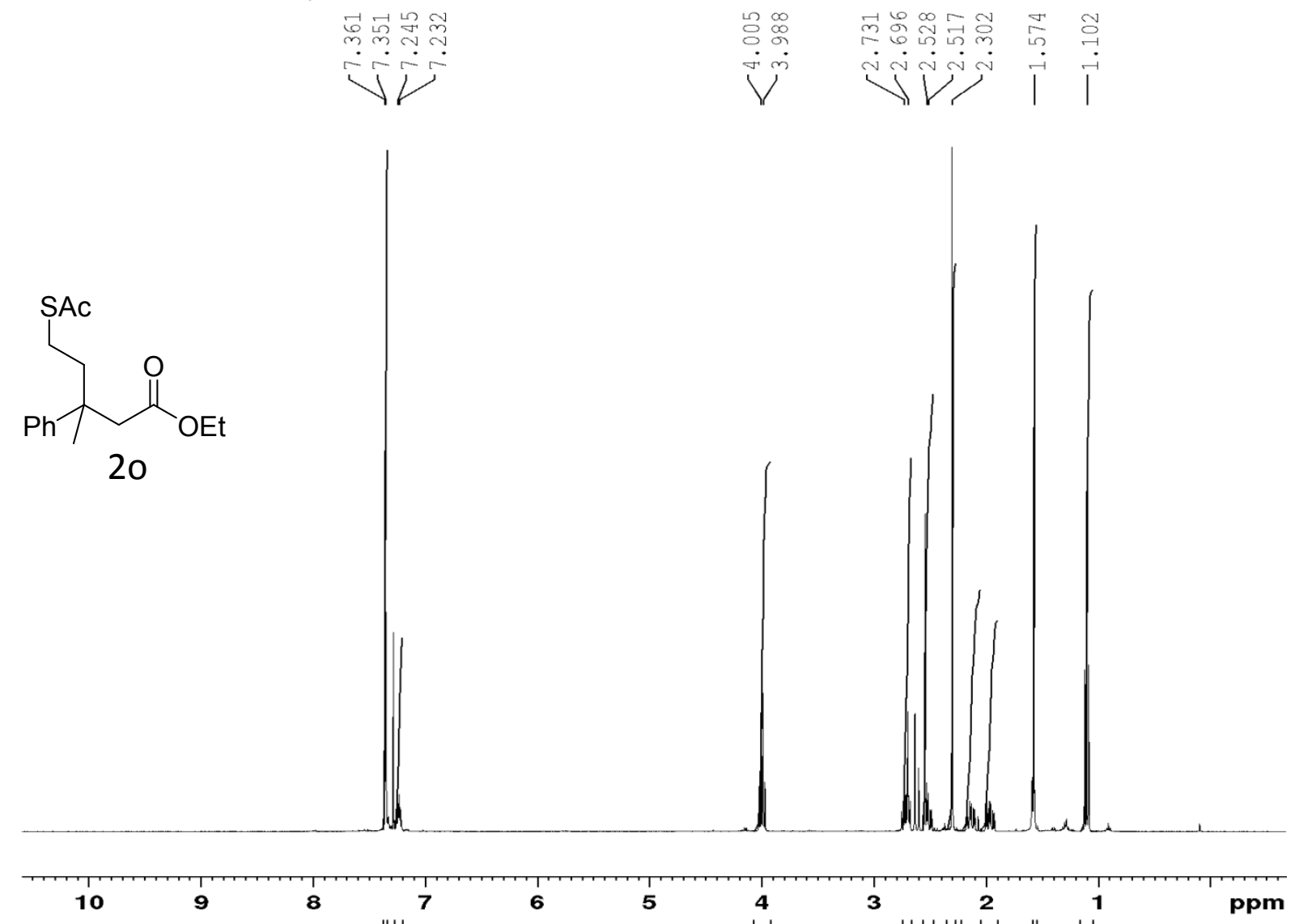

\section{이ㅇㅛㅛ}

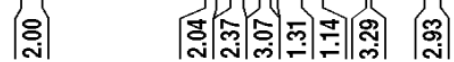

Supplementary Figure S2O.

$2013 \mathrm{C} N \mathrm{NMR}$ (101 $\mathrm{MHz}, \mathrm{CDCl} 3)$ :

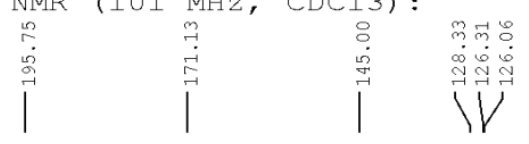<smiles>CCOC(=O)CC(C)(CC[Se](C)(C)C)c1ccccc1</smiles>

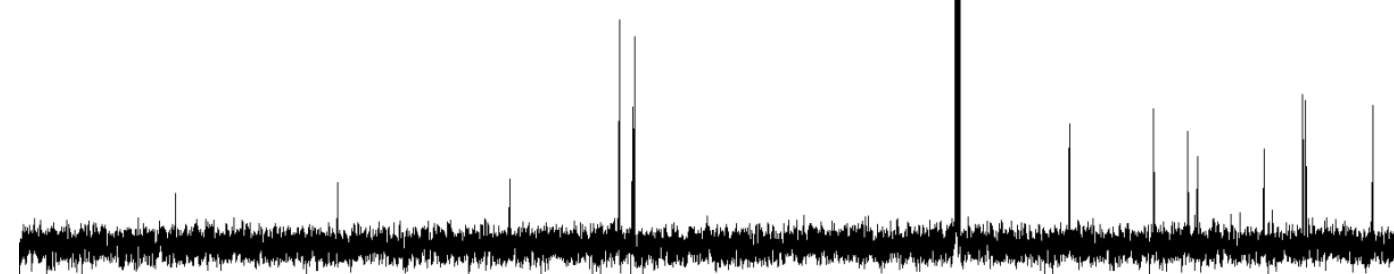

\begin{tabular}{lllllllllllll}
\hline 200 & 180 & 160 & 140 & 120 & 100 & 80 & 60 & 40 & 20 & 0 & ppm \\
68 & & & & & &
\end{tabular}



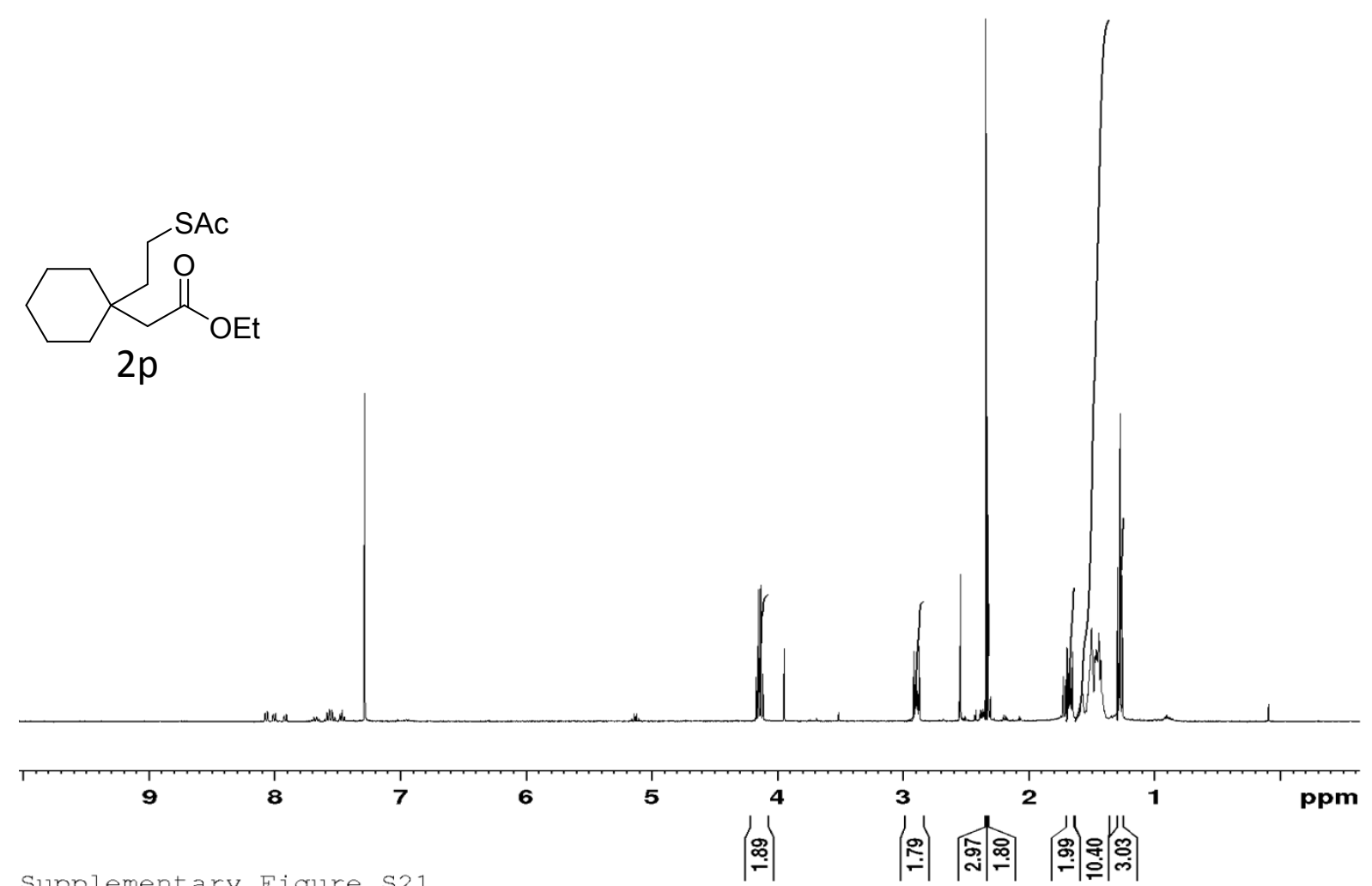

Supplementary Figure S21.

$2 \mathrm{p} 13 \mathrm{C} \mathrm{NMR}(101 \mathrm{MHz}, \underset{\mathrm{CDCl}}{\mathrm{C}})$ :

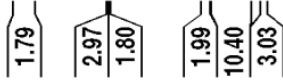

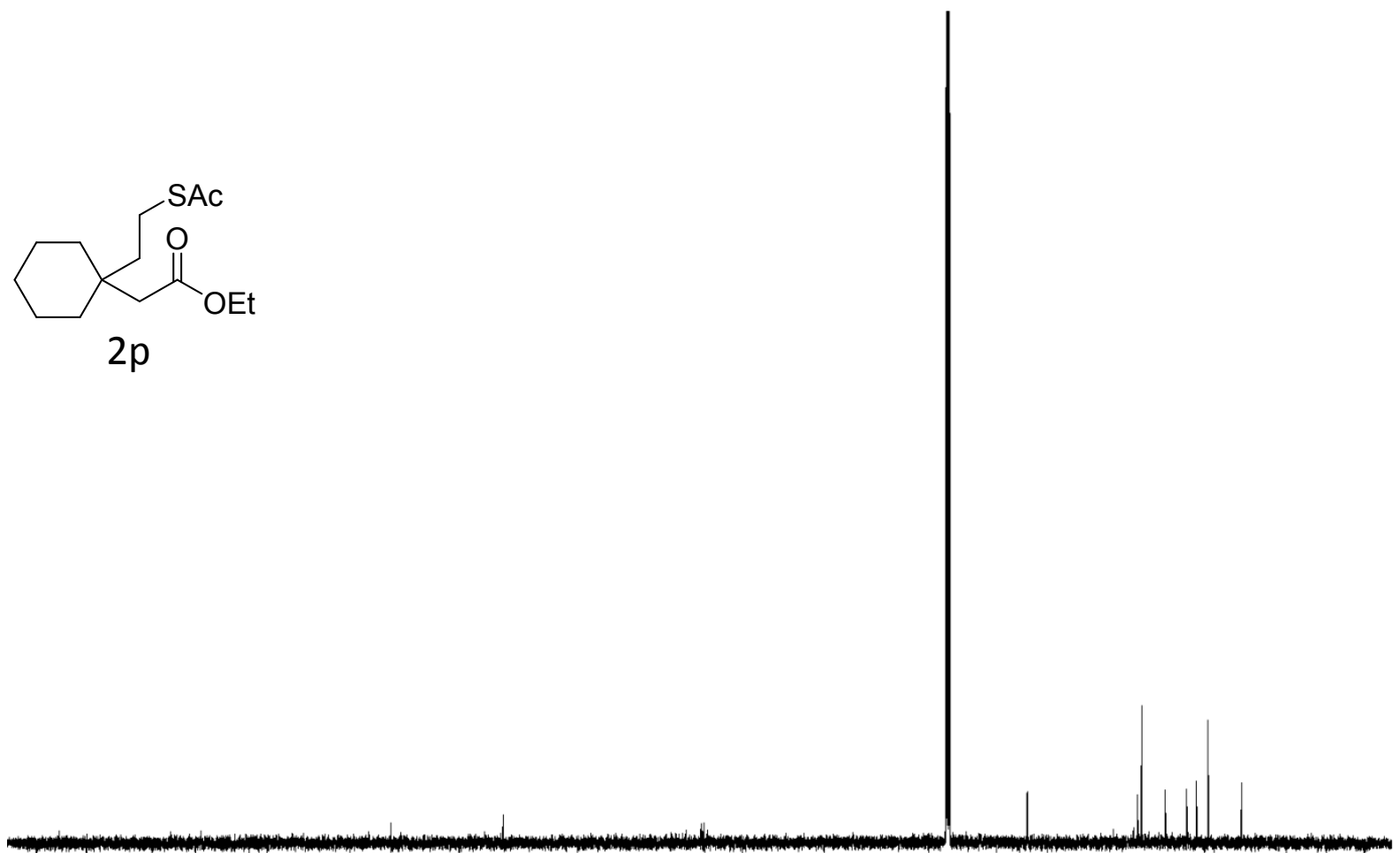

\begin{tabular}{lllllllllllllll}
\hline 260 & 240 & 220 & 200 & 180 & 160 & 140 & 120 & 100 & 80 & 60 & 40 & 20 & ppm
\end{tabular}



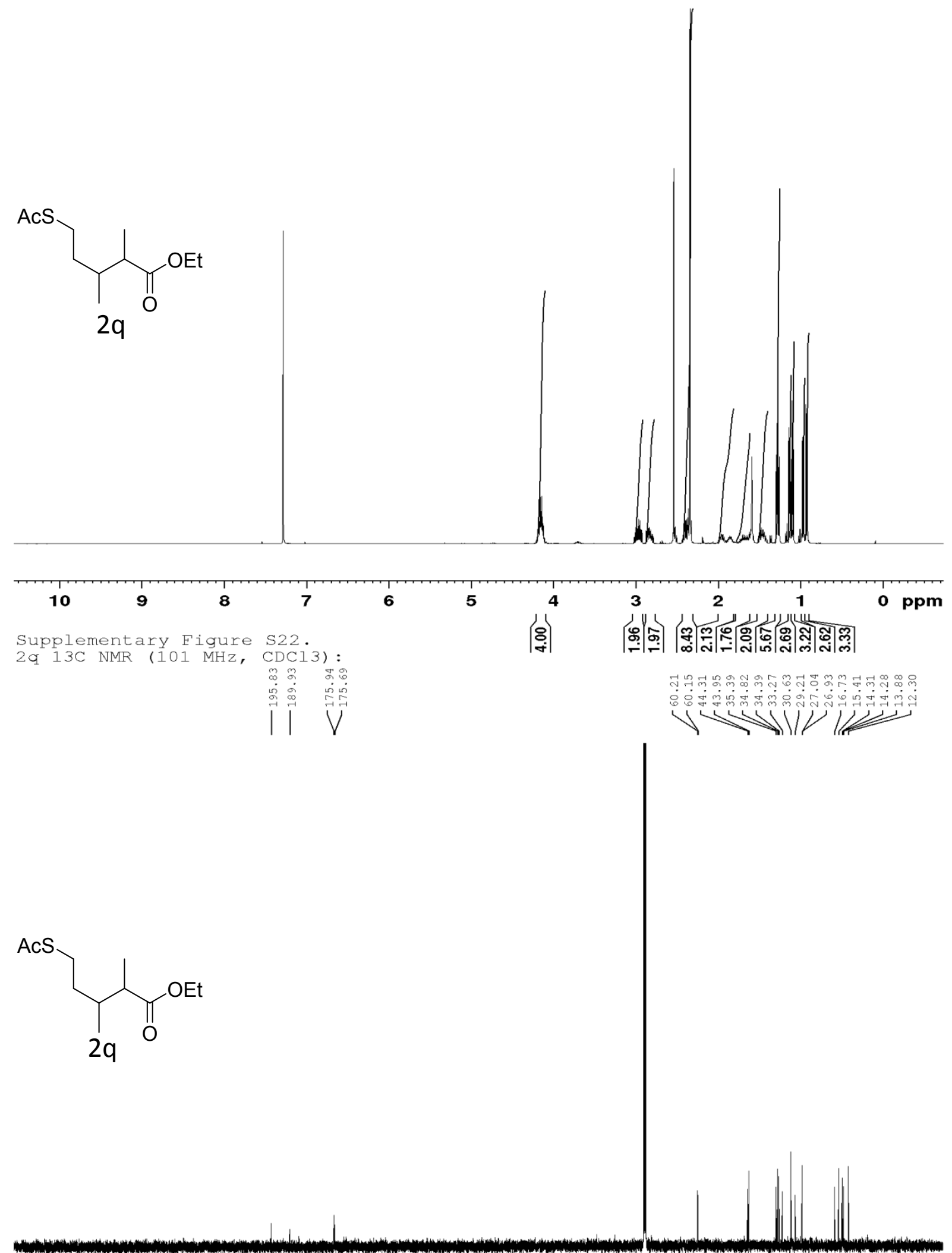

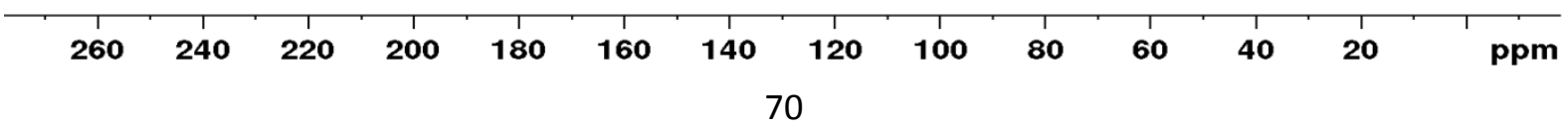



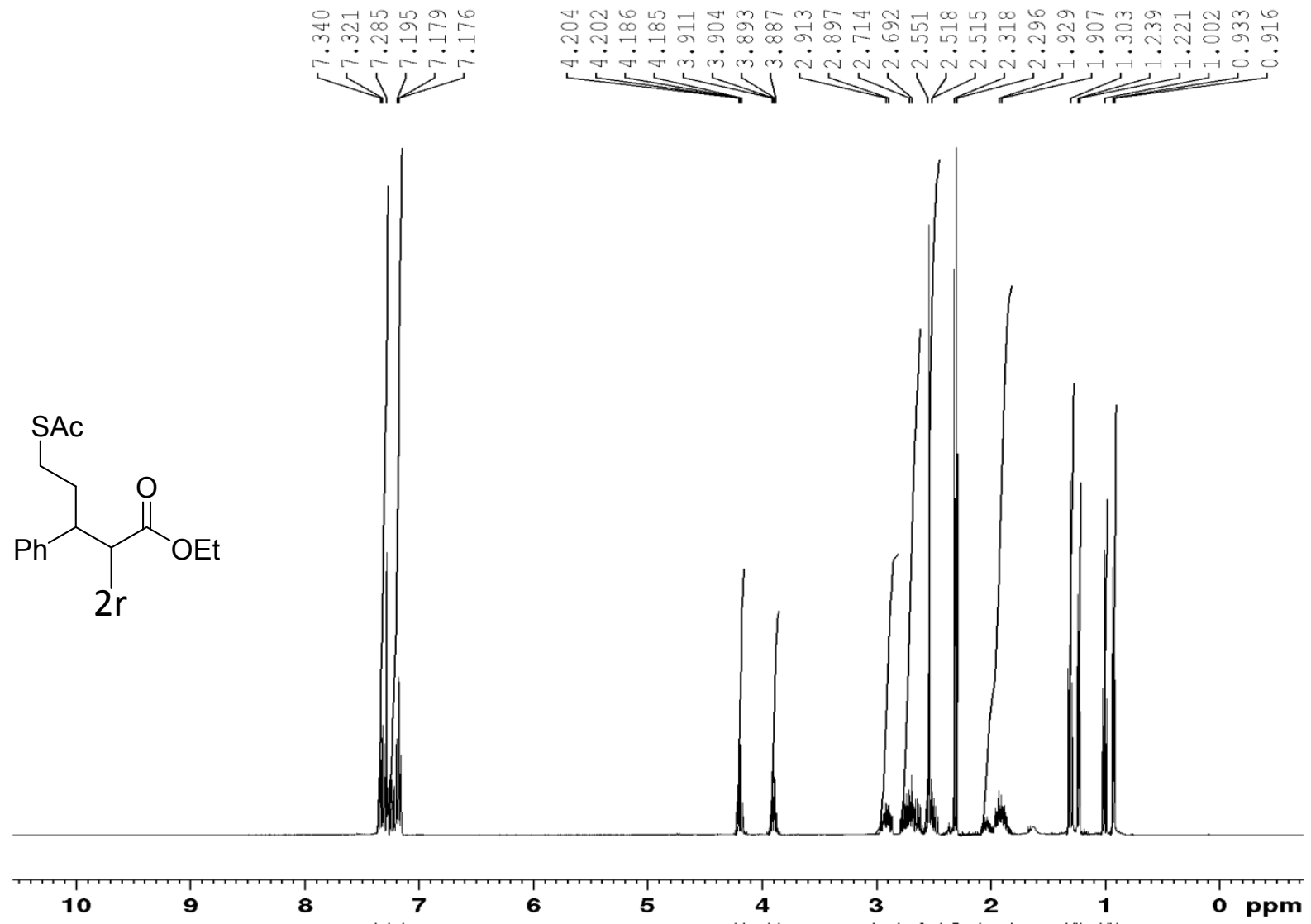

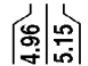

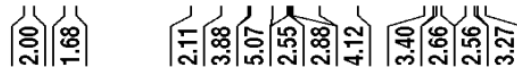

supplementary Figure S23.

2 r 13C NMR (101 MHz, CDCl3):

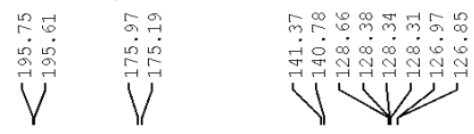

$\overbrace{2 r}^{S A C}$

$260240 \quad 220$
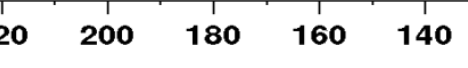

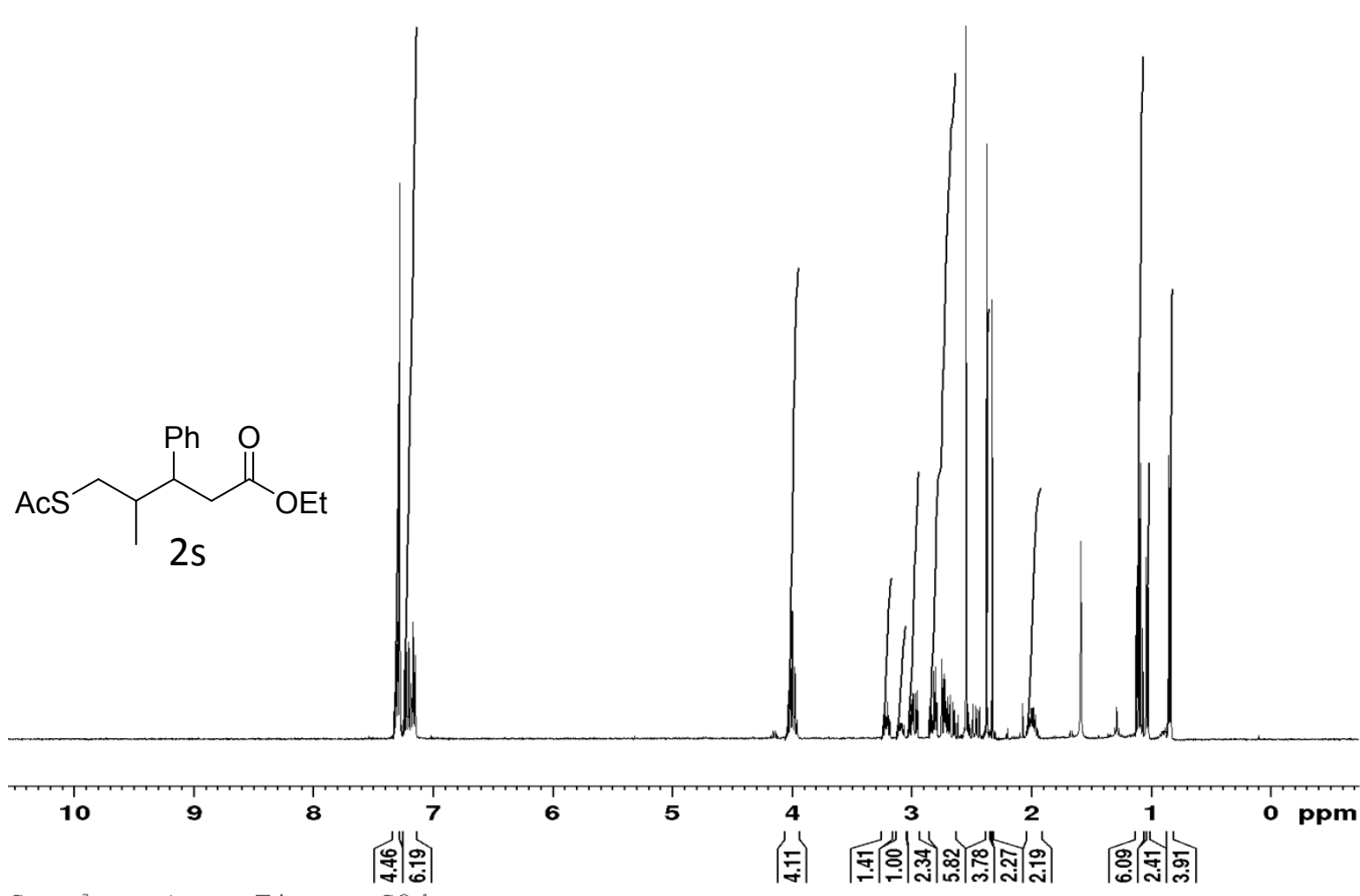

Supplementary Figure S24.

2s 13C NMR (101 MHz, CDCl3):

|

$\underbrace{\mathrm{Ph}}_{2 \mathrm{~s}}$

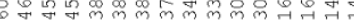

vilf

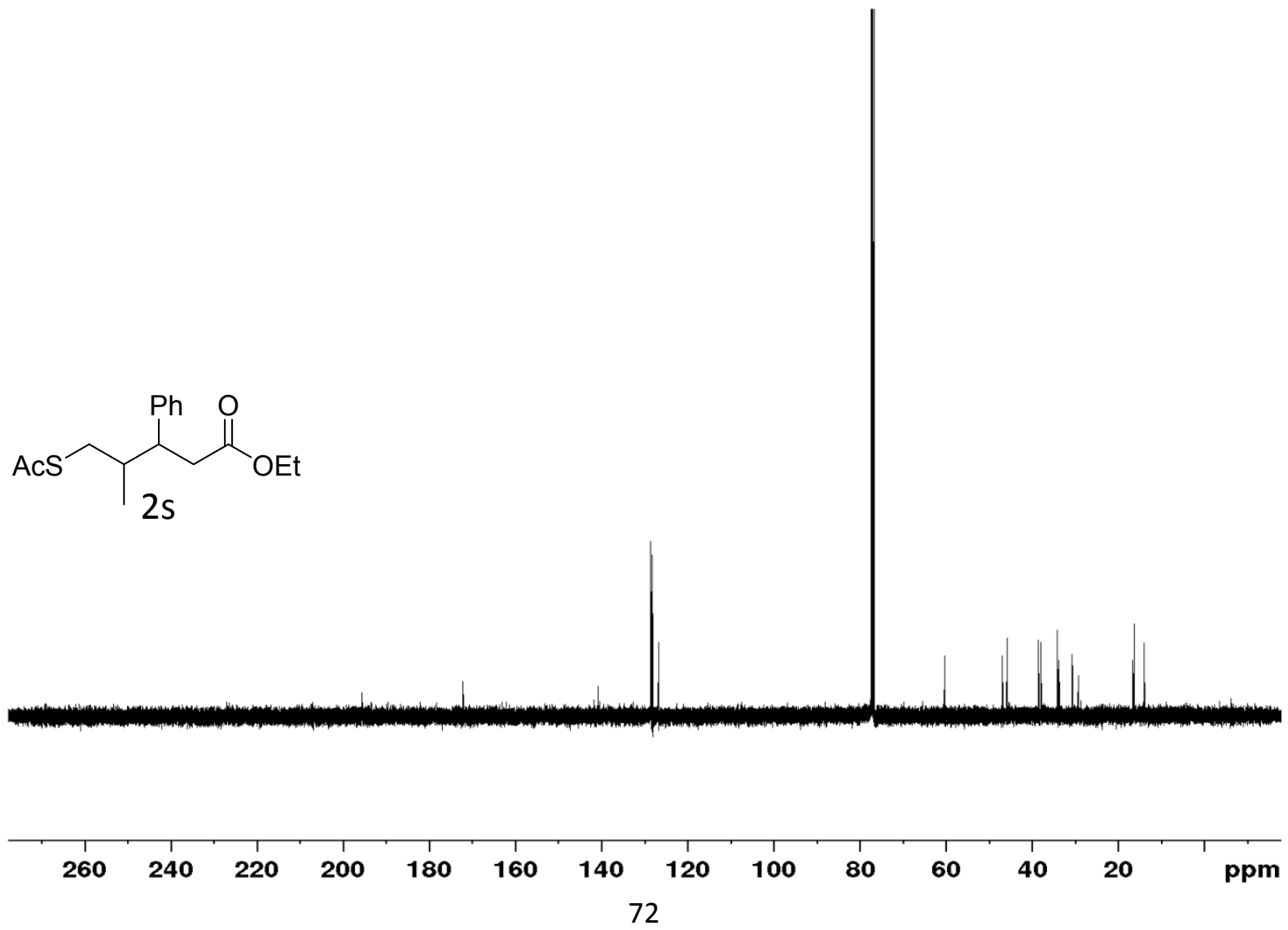




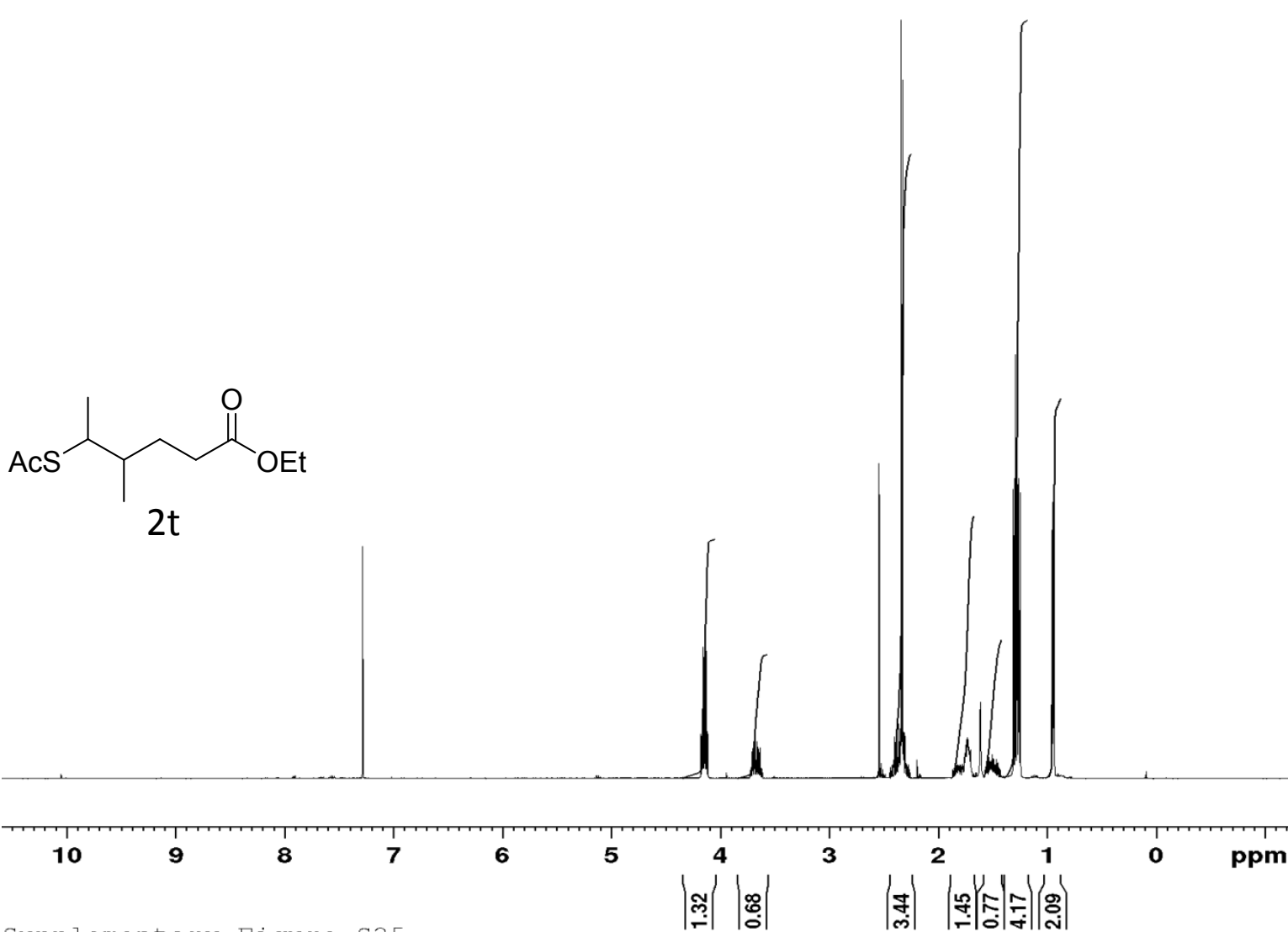

Supplementary Figure S25.
2t 13C NMR (101 MHz, CDC13):

Vं

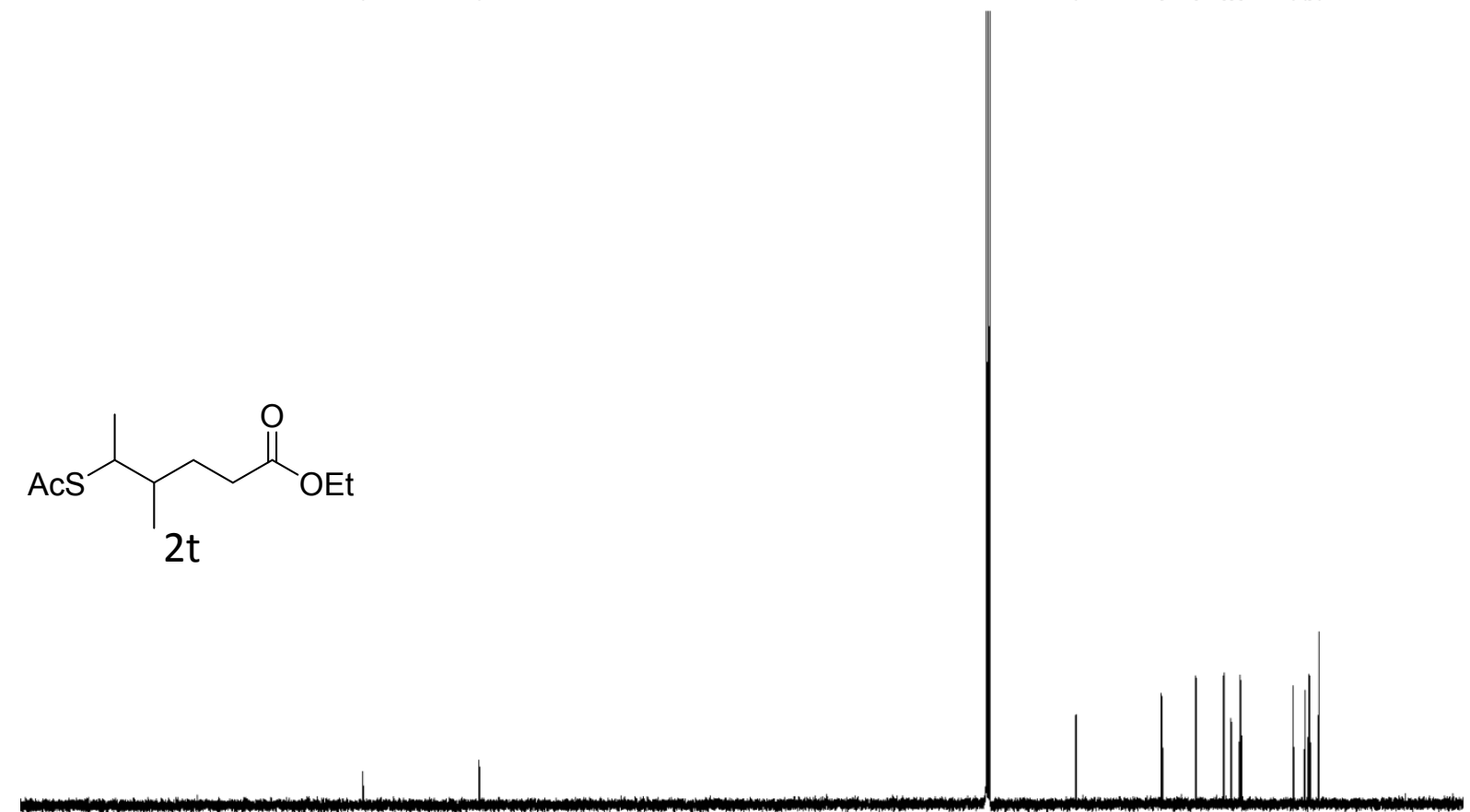

等

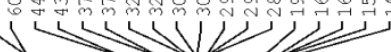




\section{$\begin{array}{lll}2 & \end{array}$}

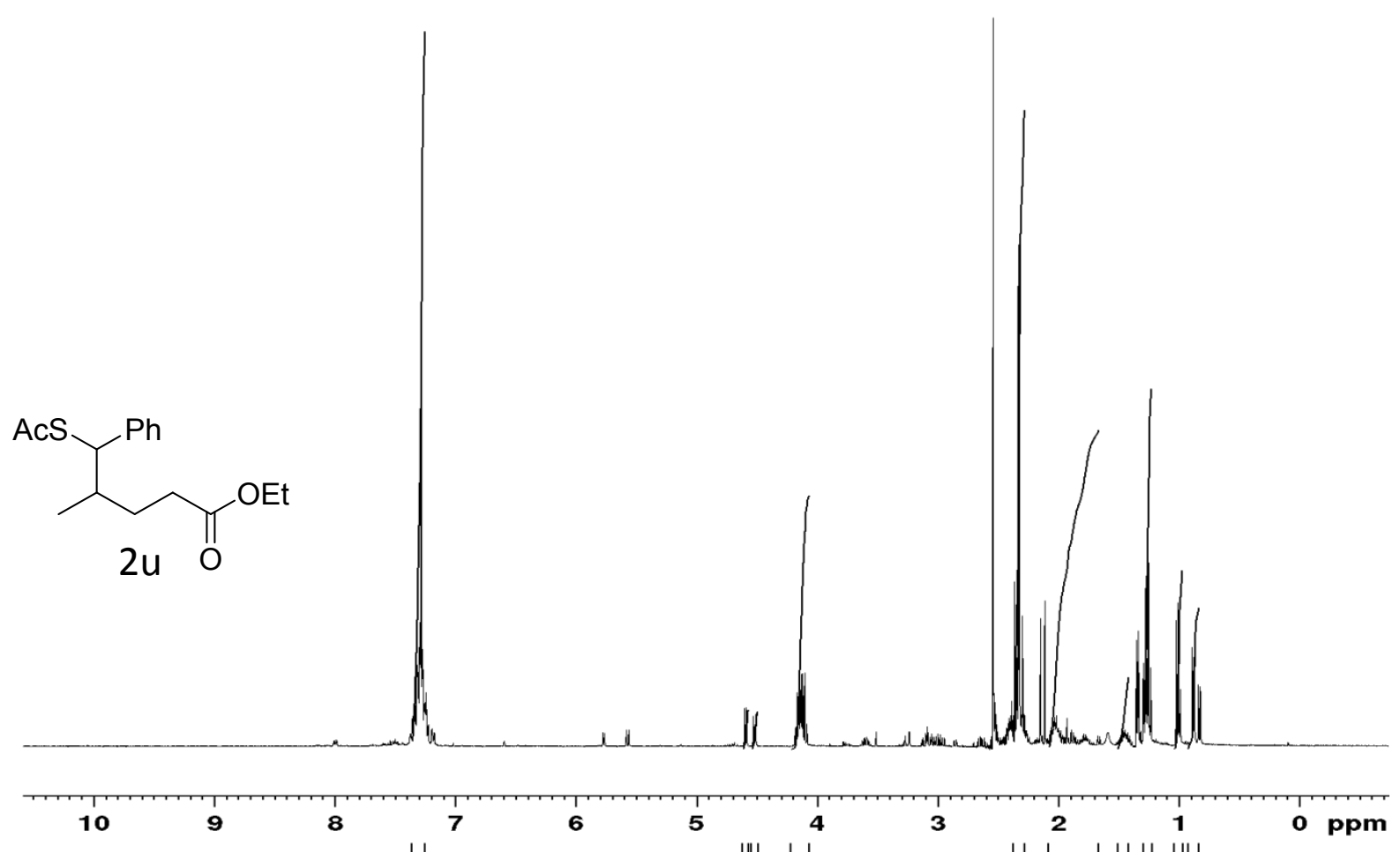

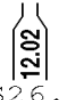

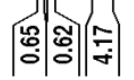

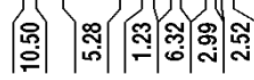

Supplementary Figure S26.
2u 13C NMR (101 $\mathrm{MHz}$, CDC13)

$$
\text { \}}
$$

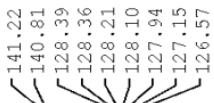

V V<smiles>[Z10]C(C)C(C(=[As])CCC(=O)OCC)c1ccccc1</smiles> 

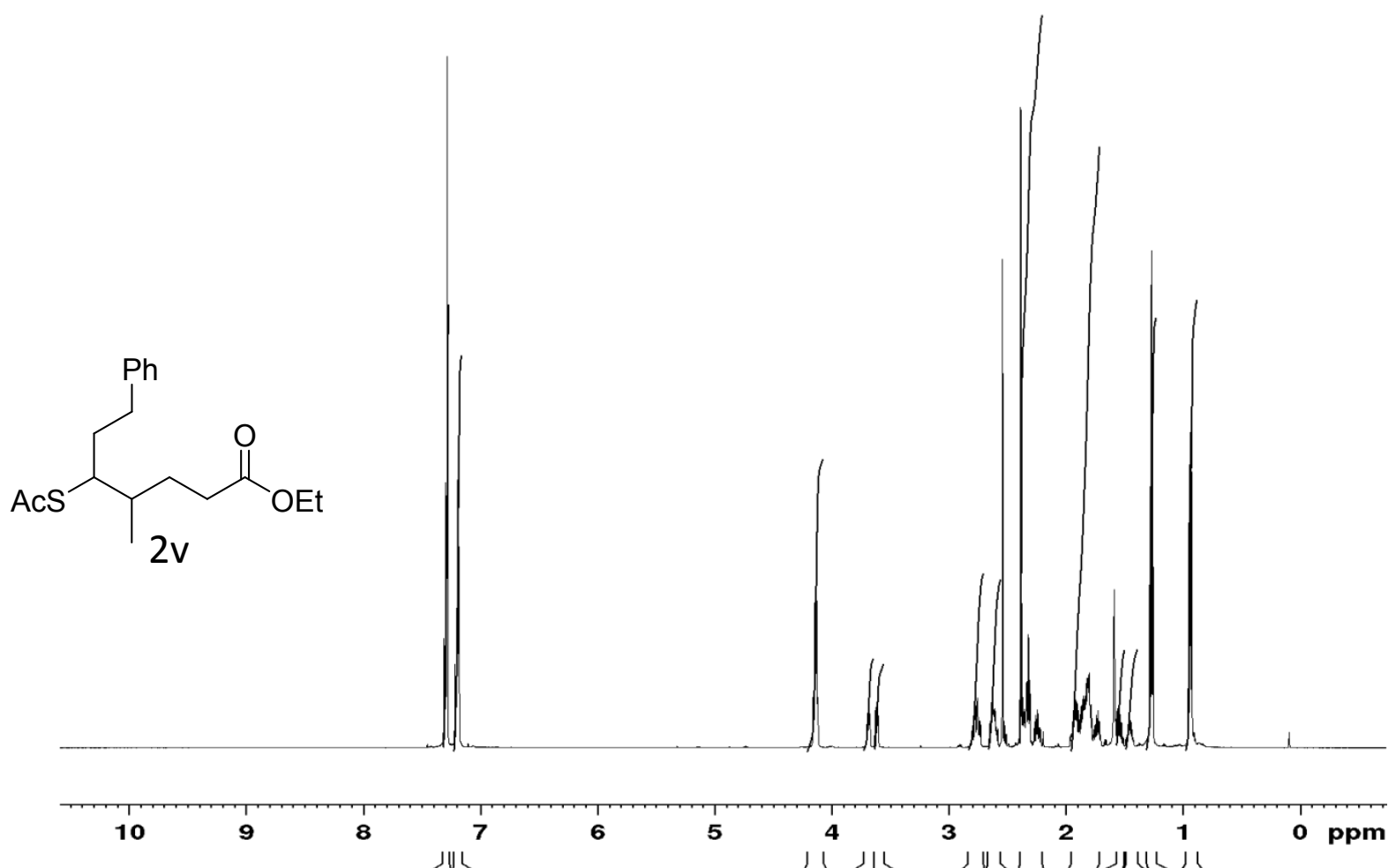
䍐|

|

Supplementary Figure S28.
2V 13C NMR (151 MHz, CDC13):

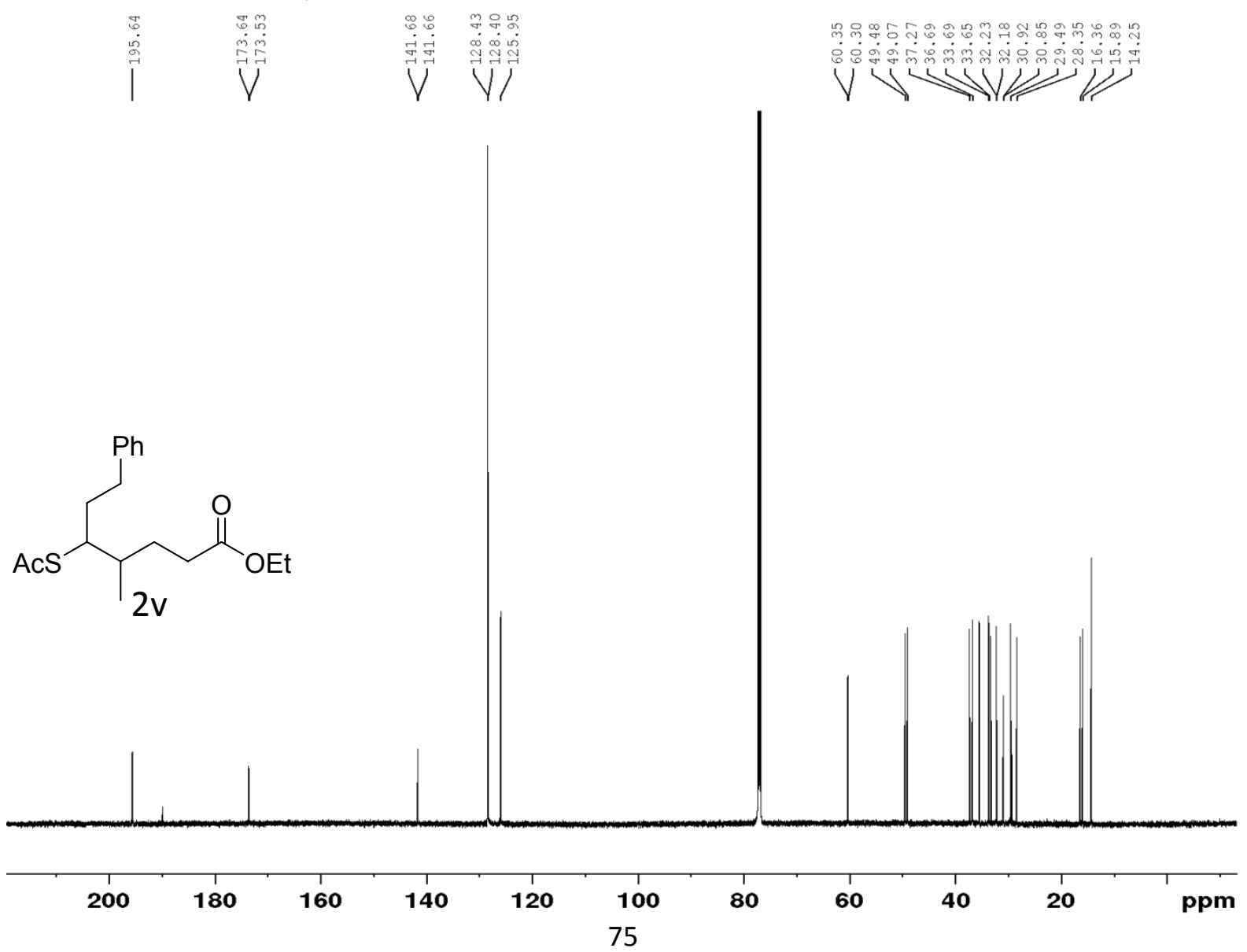




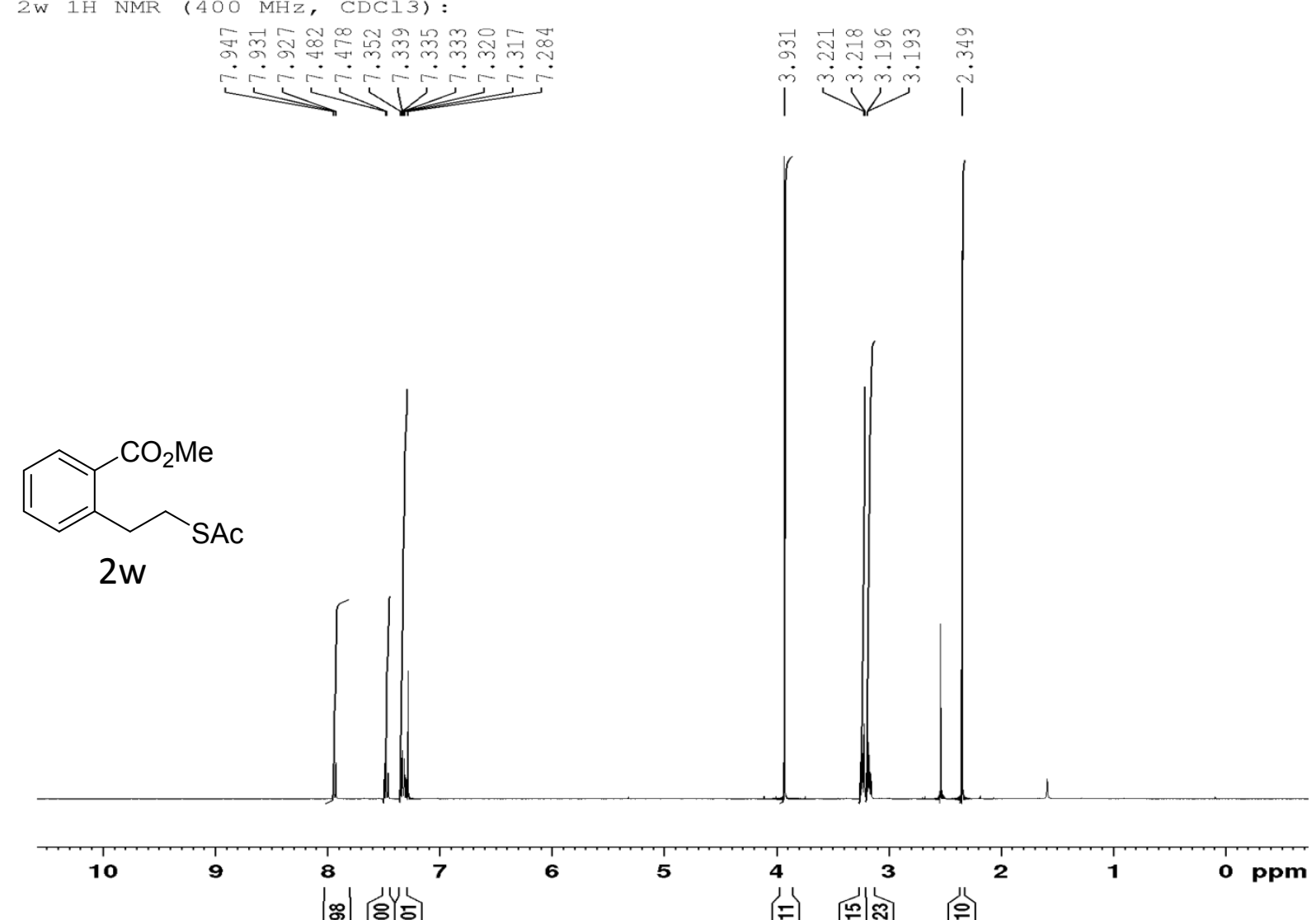

Supplementary Figure S28.

2W 13C NMR (101 MHz, CDCl3):

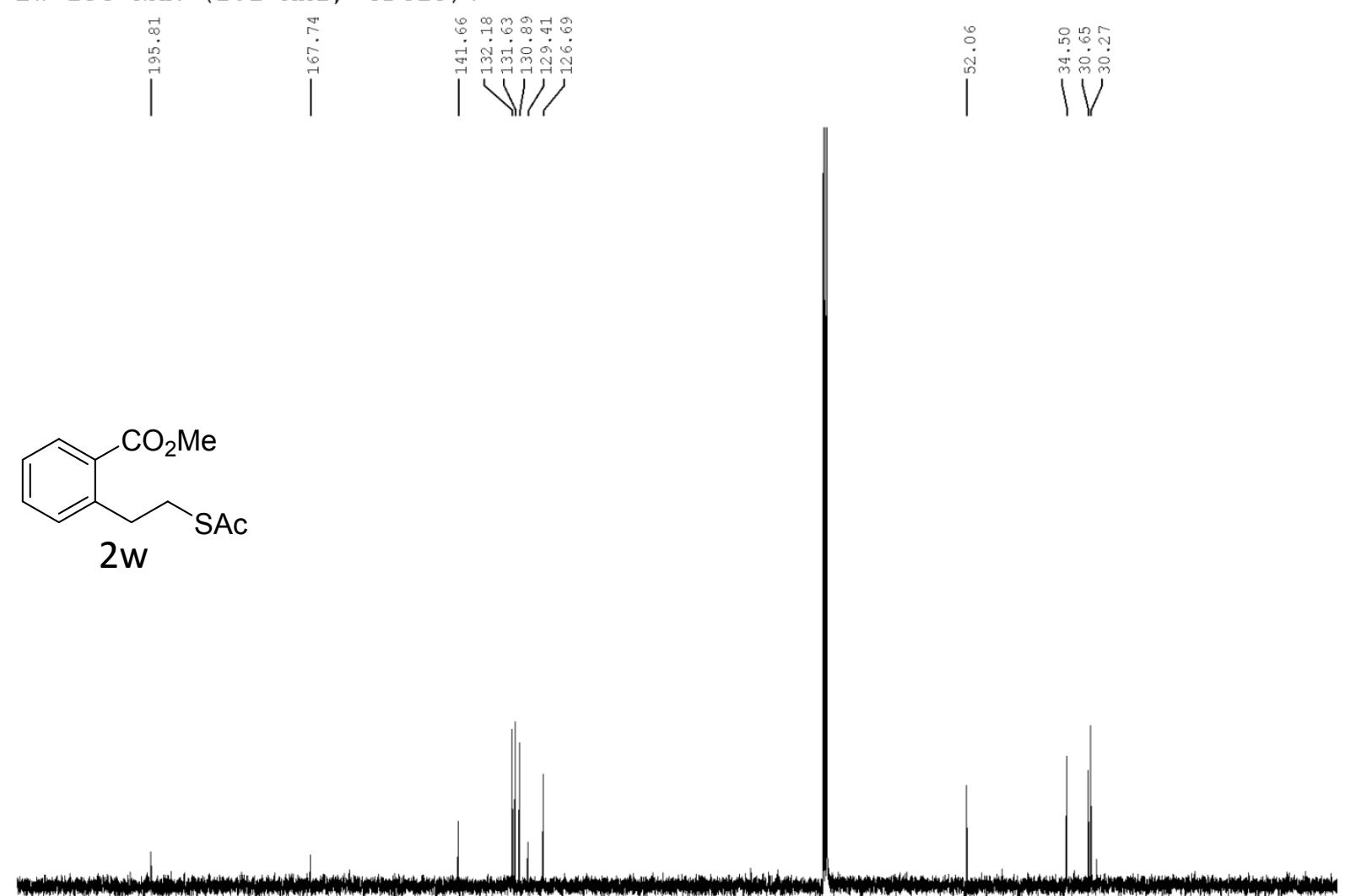

$\overbrace{2 \mathrm{w}}^{\mathrm{CO}_{2} \mathrm{Me}}$

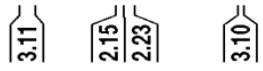

\begin{tabular}{|c|c|c|c|c|c|c|c|c|c|c|}
\hline 200 & 180 & 160 & 140 & 120 & 100 & 80 & 60 & 40 & 20 & ppm \\
\hline & & & & & 76 & & & & & \\
\hline
\end{tabular}



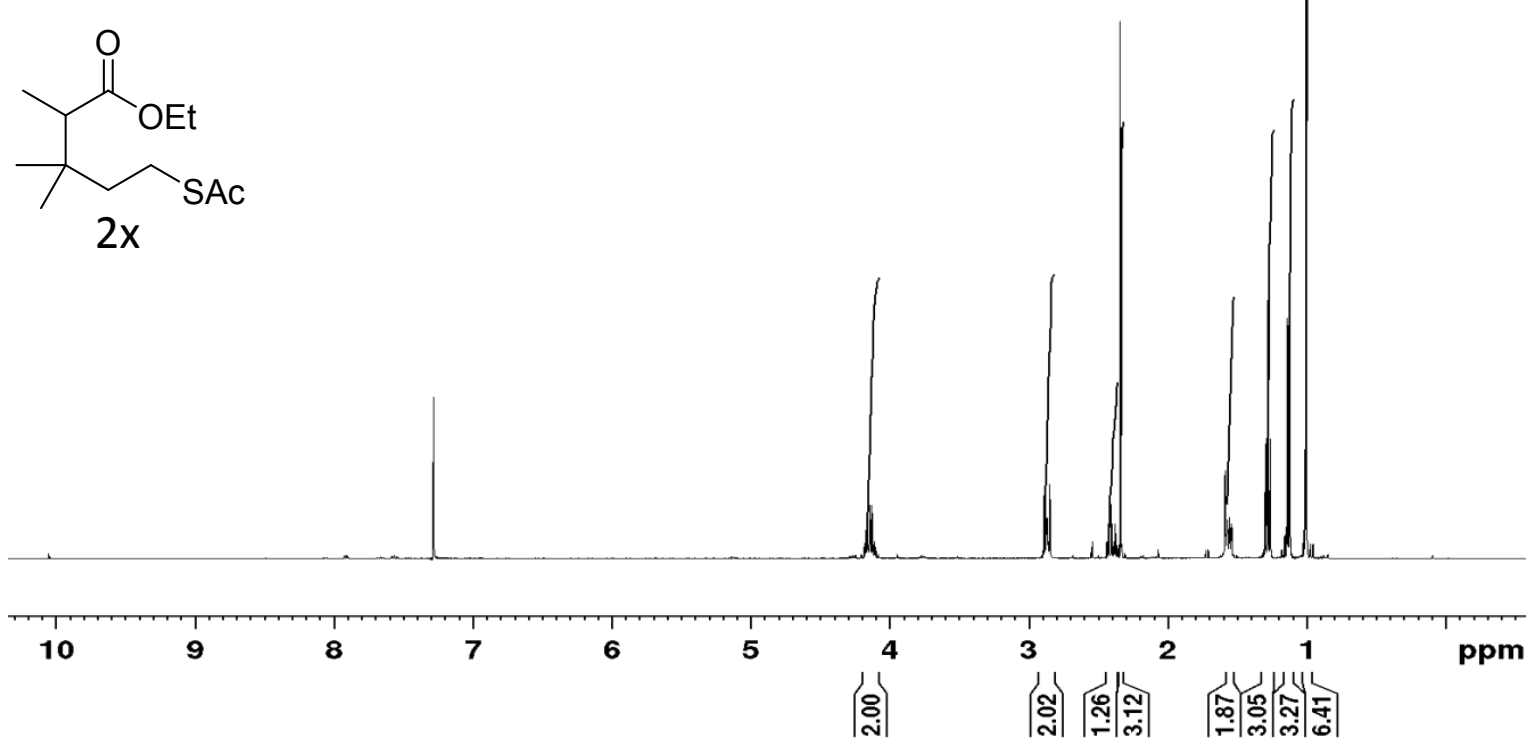

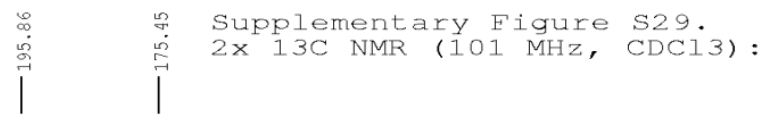
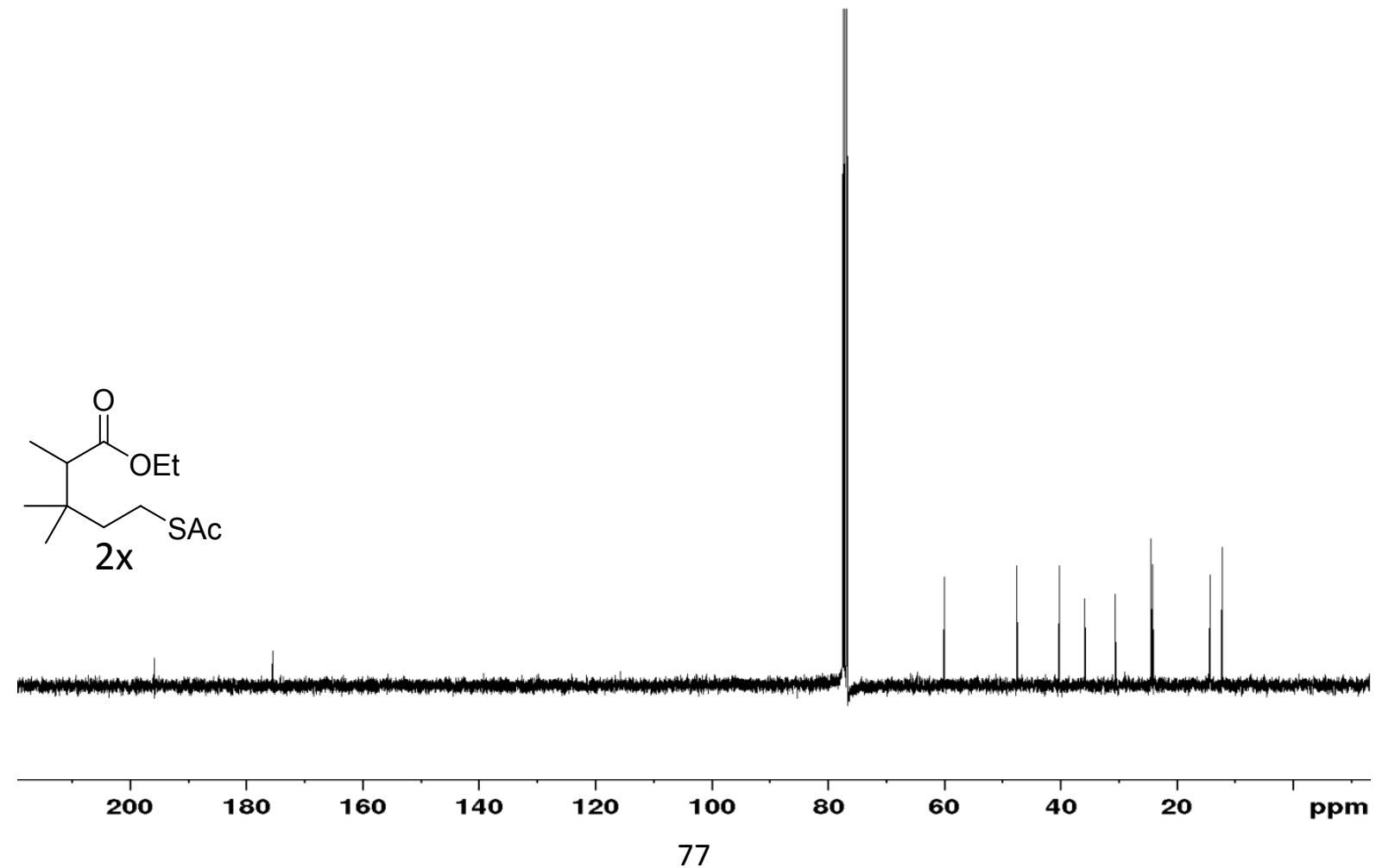


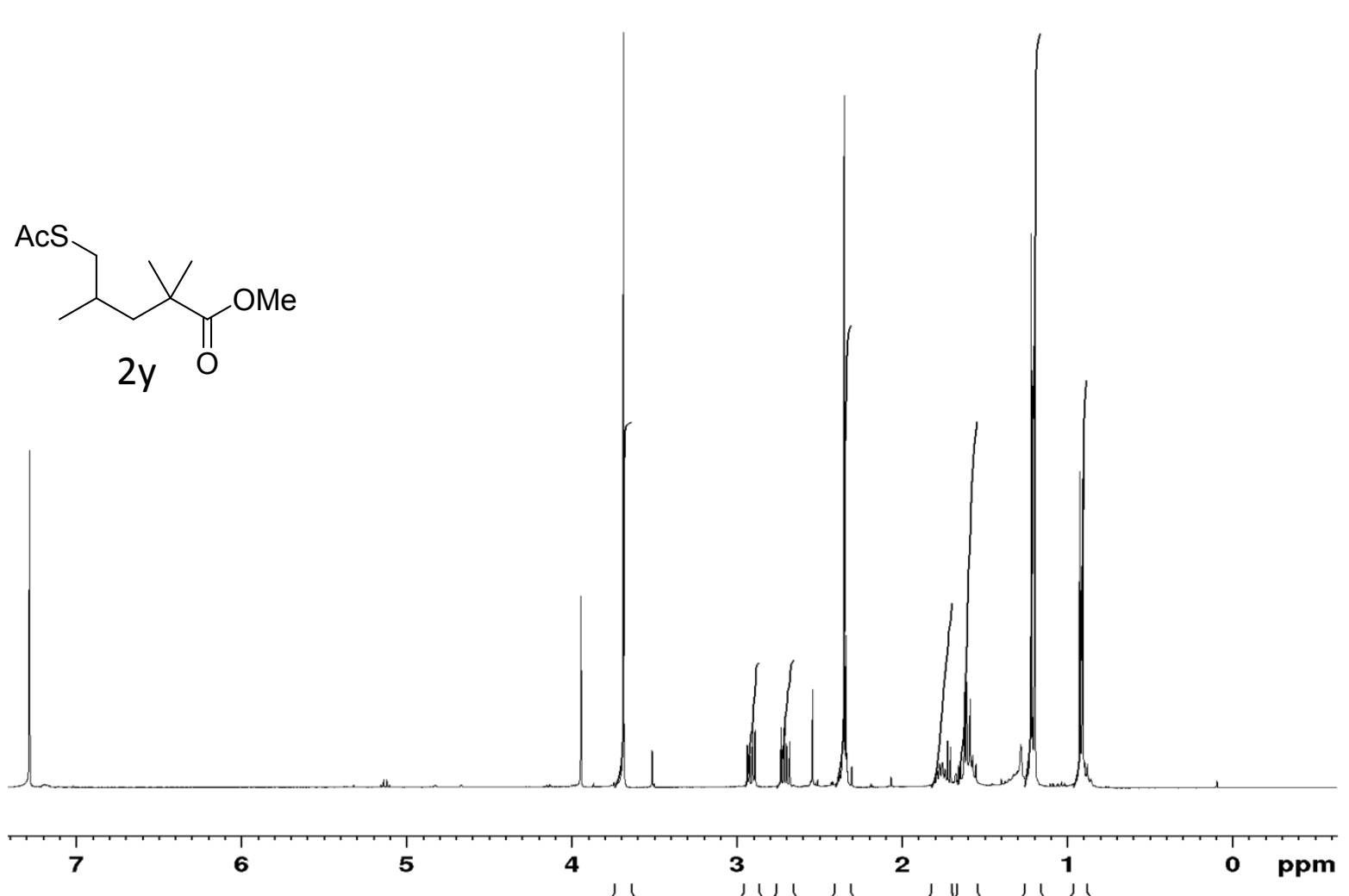

|

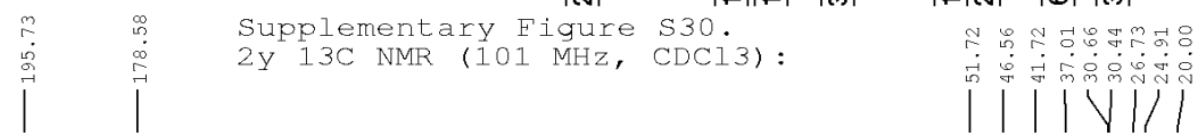

$\overbrace{2 y}^{\mathrm{AcS}} \mathrm{X}_{\mathrm{O}}^{\mathrm{OMe}}$

\begin{tabular}{|c|c|c|c|c|c|c|c|c|c|c|c|}
\hline 200 & 180 & 160 & 140 & 120 & 100 & 80 & 60 & 40 & 20 & 0 & ppm \\
\hline & & & & & 78 & & & & & & \\
\hline
\end{tabular}



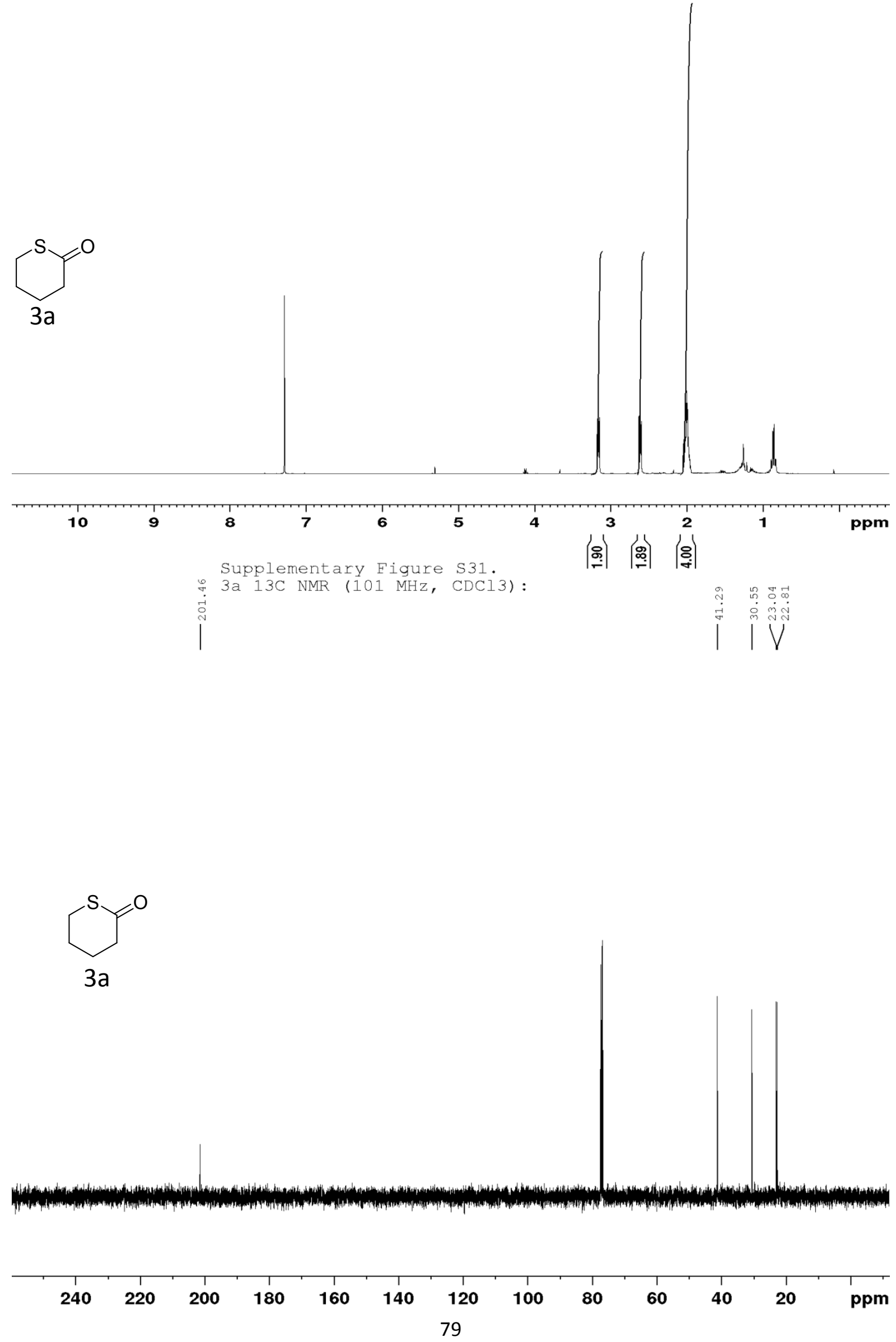
<smiles>CC1CCCSC1=O</smiles>

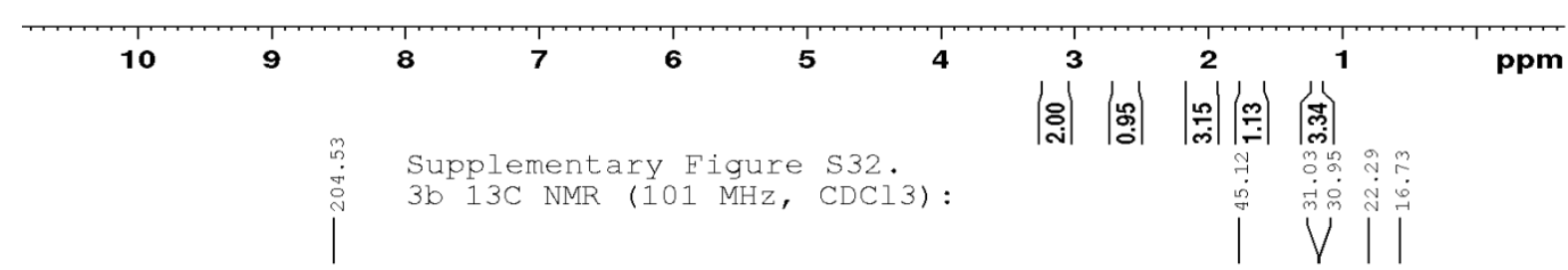<smiles>CC1CCCSC1=O</smiles>

$3 b$

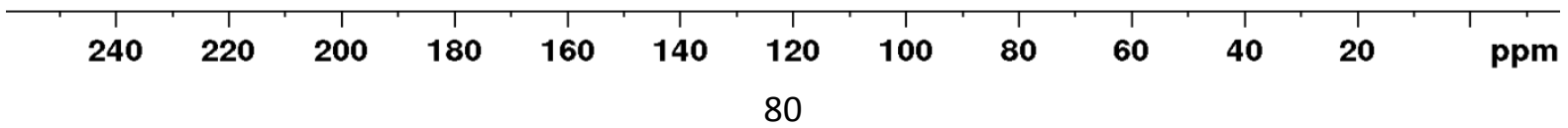




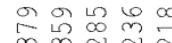

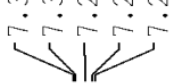

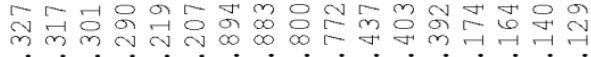

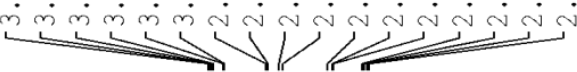
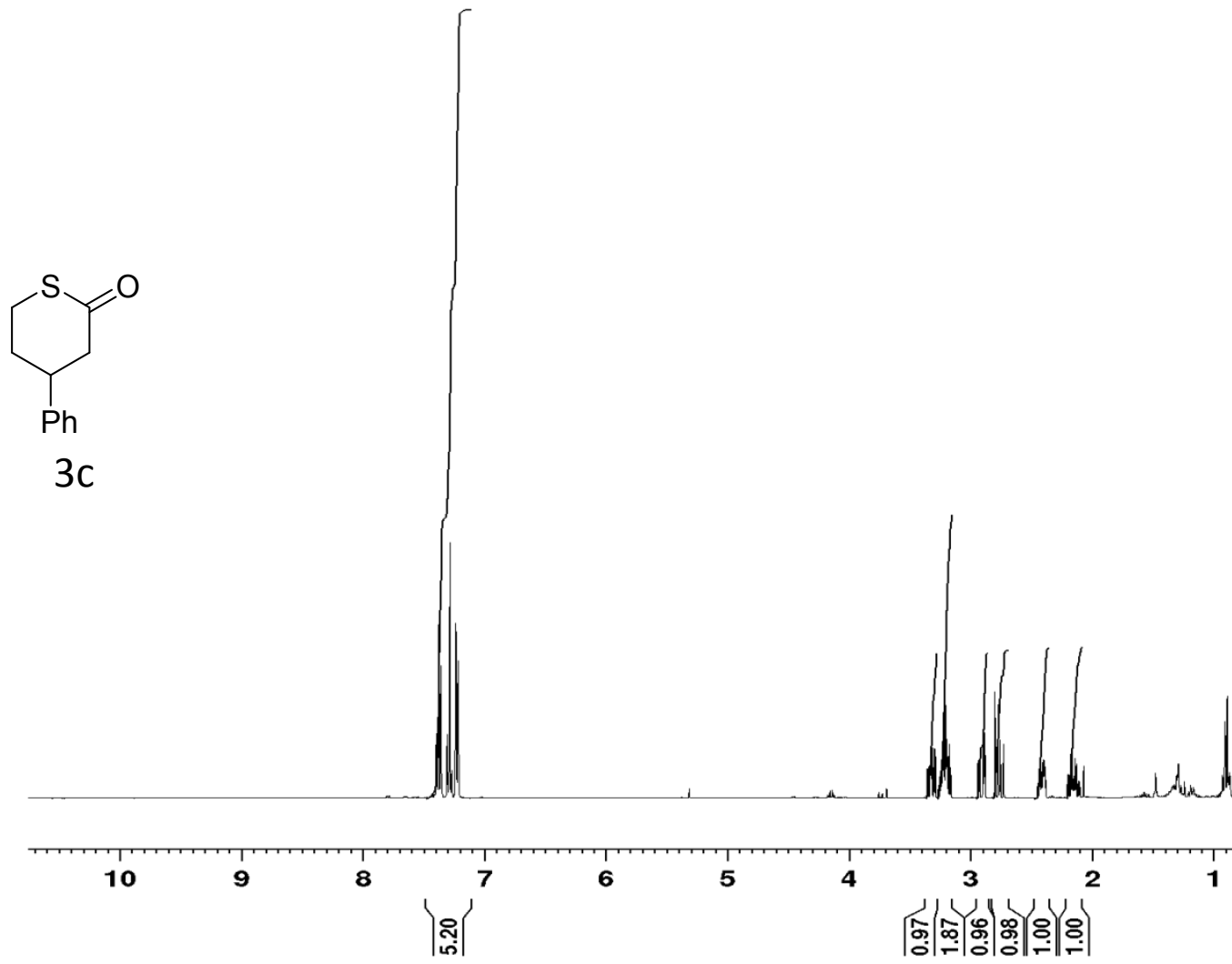

Supplementary Figure S33.

3C 13C NMR (101 MHz, CDCl3):

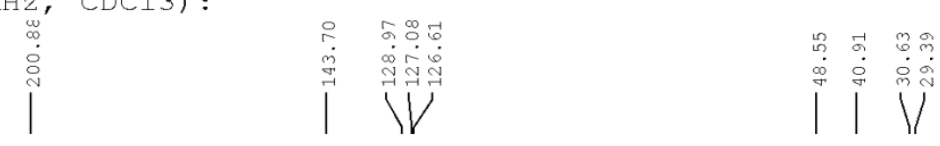<smiles>CC(C)PC1CCSC(=O)C1</smiles>

$3 c$

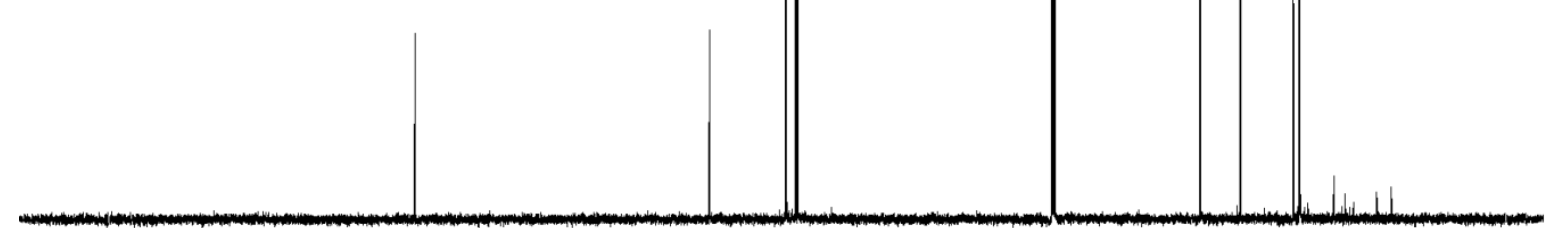


Supplementary Figure $\$ 34$.

3d 1H NMR (400 MHz, CDCl3)

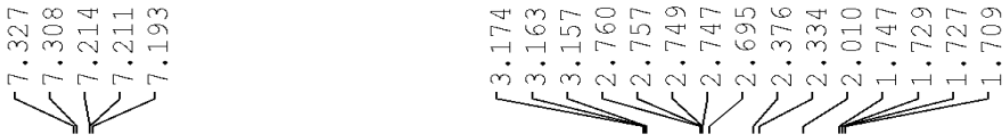

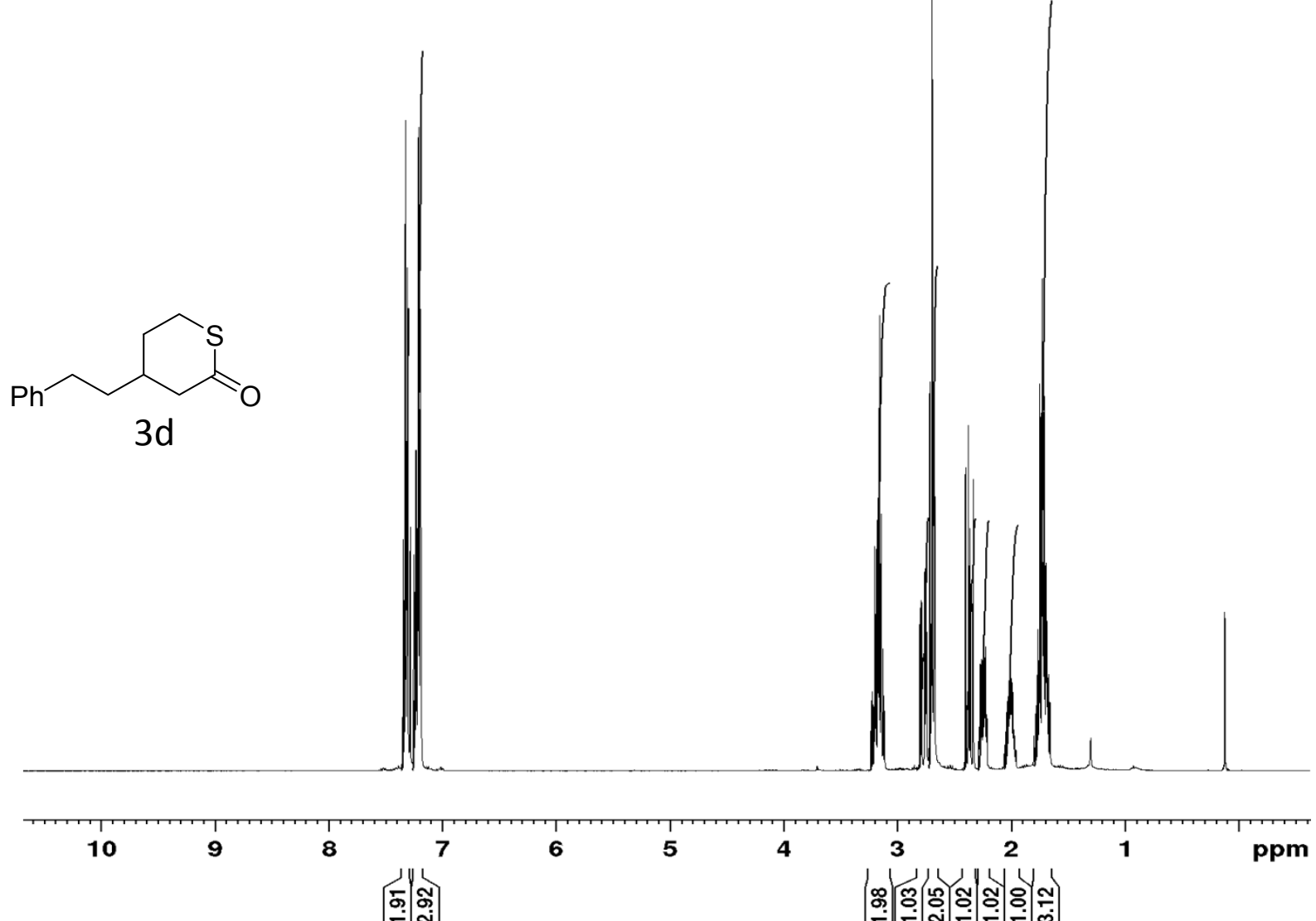

Supplementary Figure S34.

3d 13C NMR (101 MHz, CDCl3):
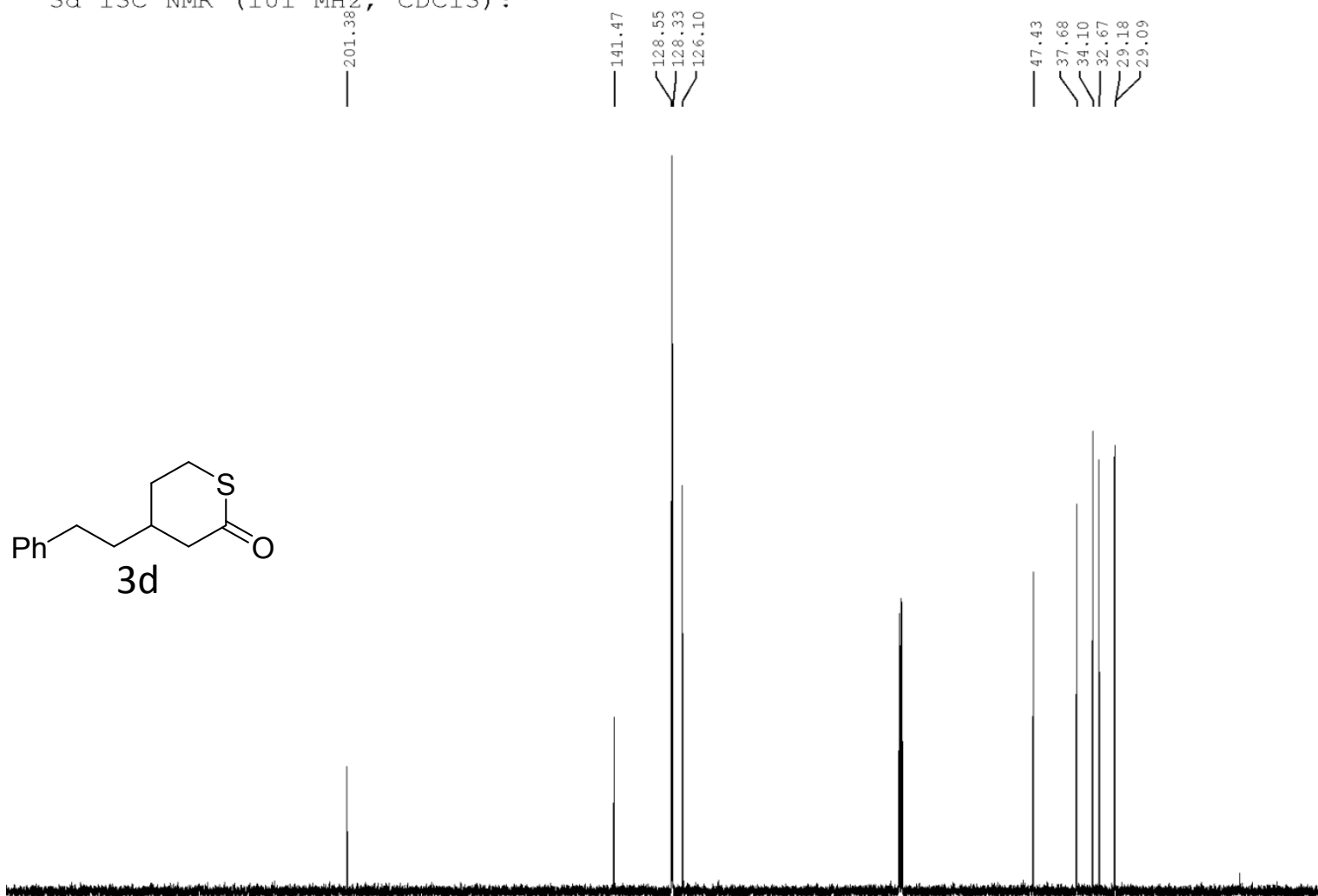

260

240220

200180160 
<smiles>[13CH3]c1ccc(C2CCSC(=O)C2)cc1</smiles>

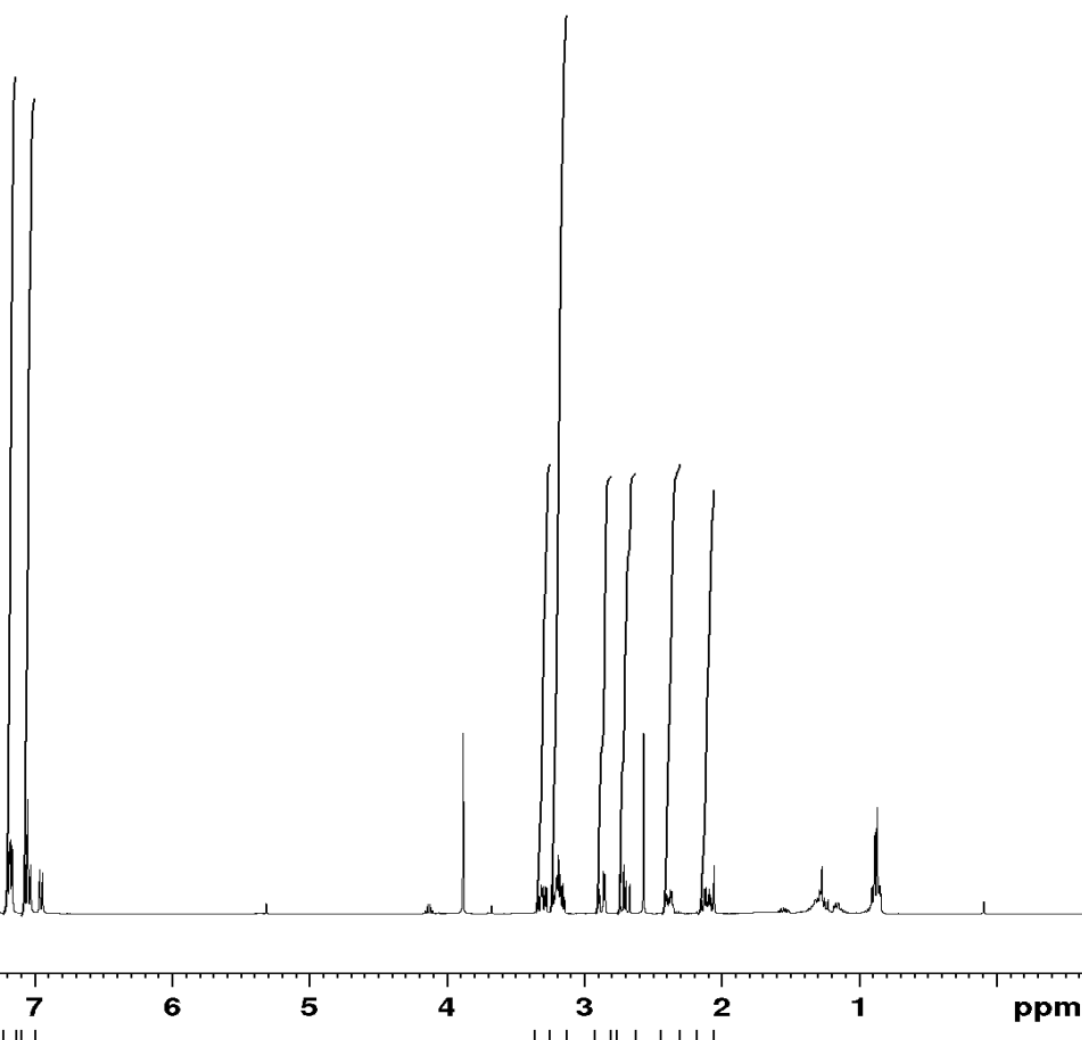

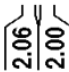

Supplementary Figure S35

1H NMR (101 MHz, CDCl3):

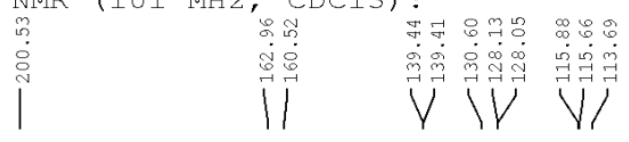

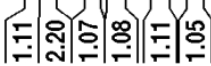<smiles></smiles>

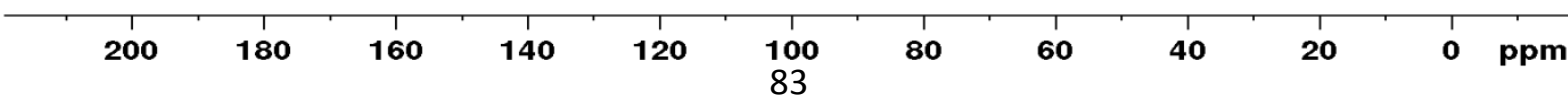




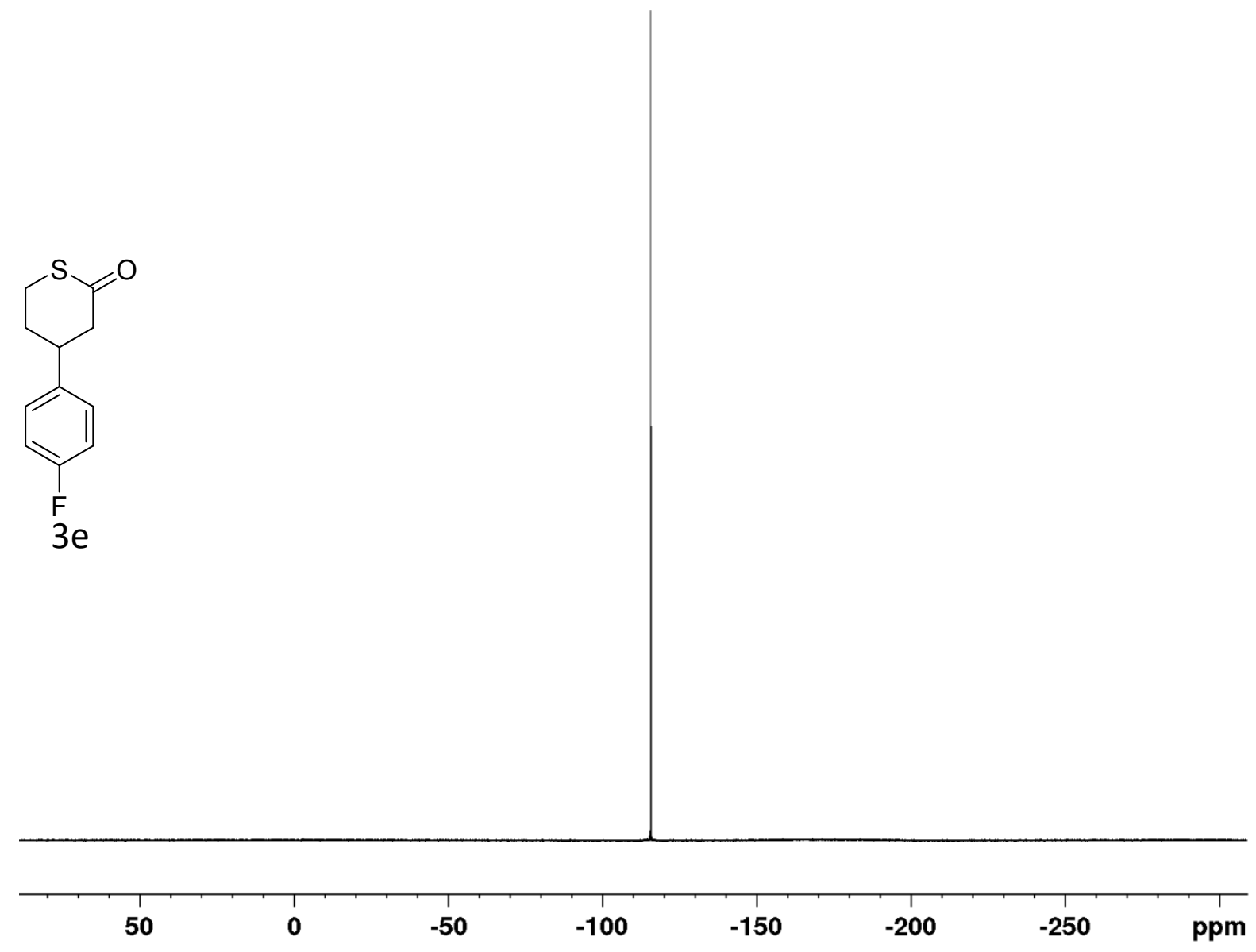


<smiles>O=C1CC(c2ccc(Cl)cc2)CCS1</smiles>
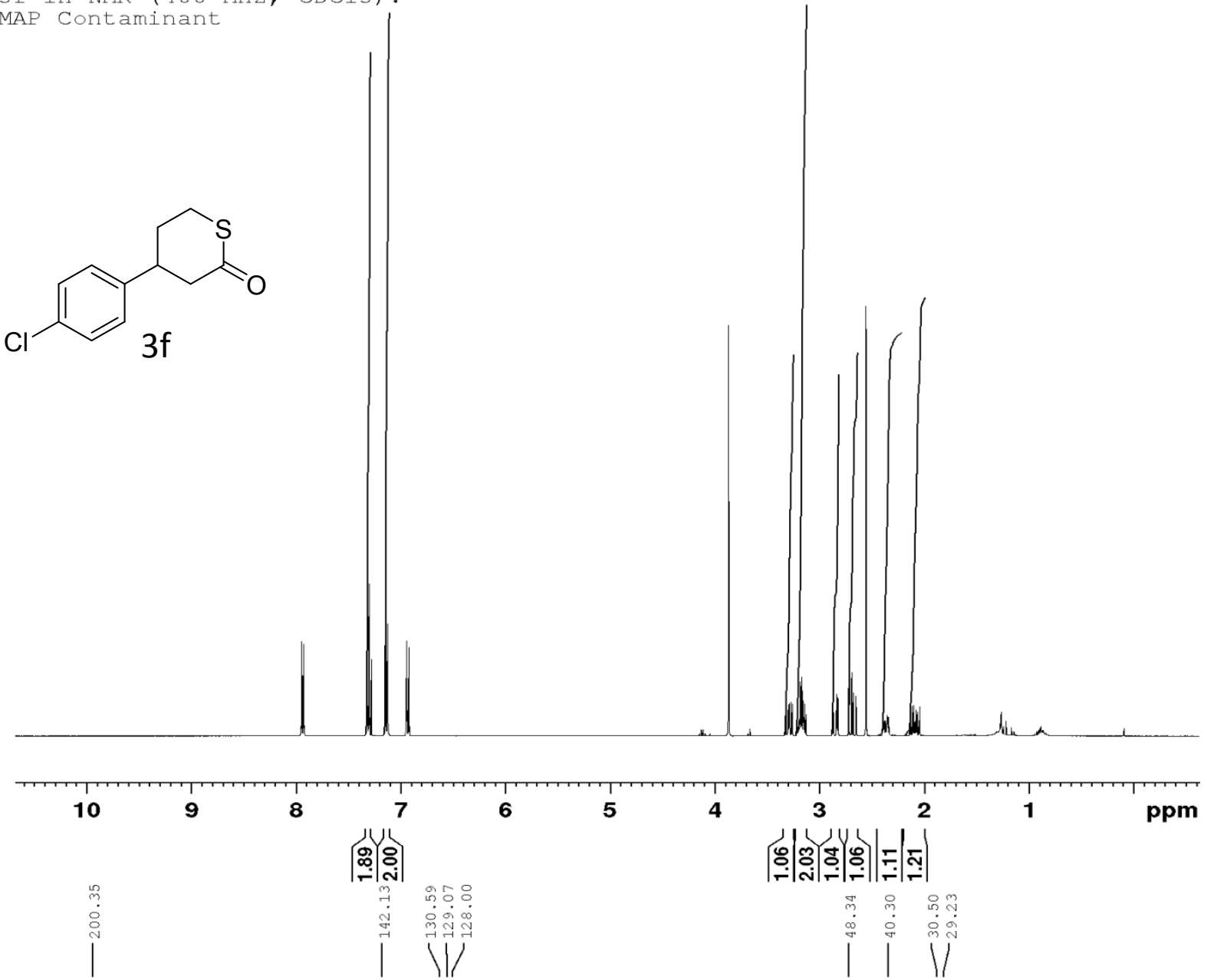

Supplementary Figure $\$ 36$.

3f 13C NMR (101 MHz, CDCl3): MAP Contaminant<smiles>O=C1CC(c2ccc(Cl)cc2)CCS1</smiles>

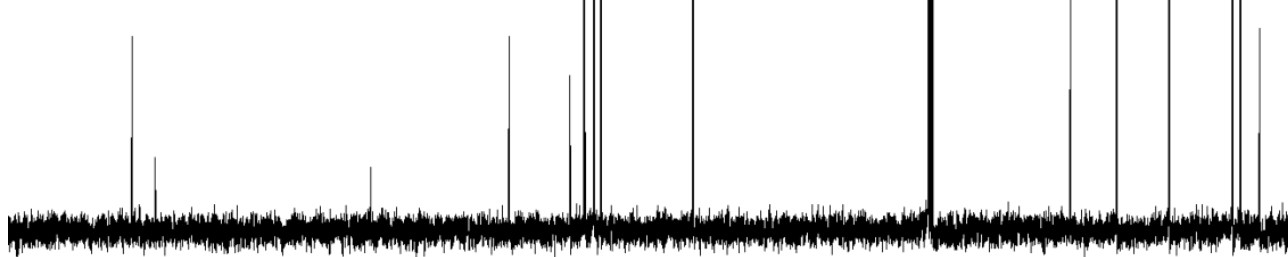

\begin{tabular}{lllllrllllll}
\hline 200 & 180 & 160 & 140 & 120 & 100 & 80 & 60 & 40 & 20 & 0 & ppm
\end{tabular}


<smiles>O=C1CC(c2ccc(Br)cc2)CCS1</smiles>
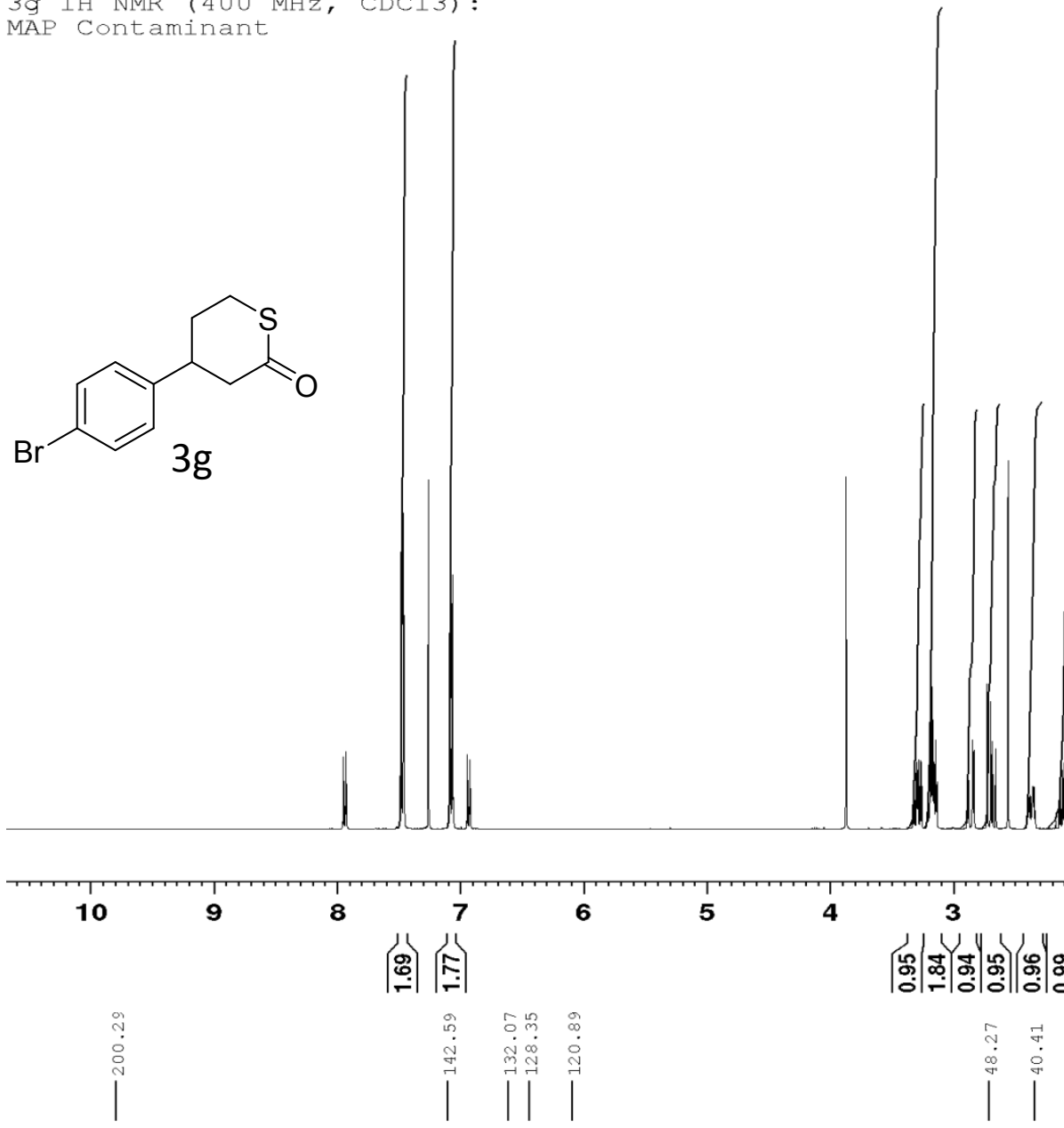

8

(罳)

2

ppm

Supplementary Figure $\$ 37$.

3g 13C NMR (101 MHz, CDCl3):

MAP Contaminant<smiles>O=C1CC(c2ccc(Br)cc2)CCS1</smiles>

\section{|}

|

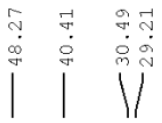
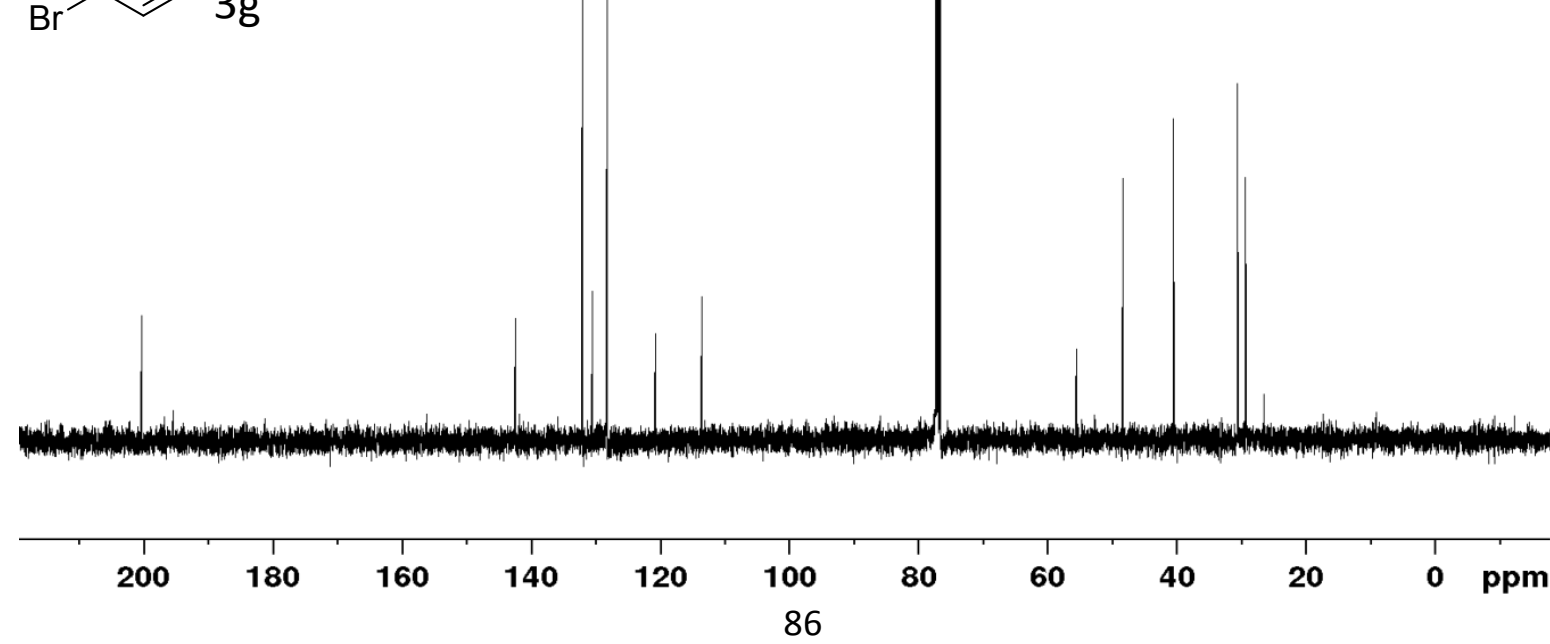

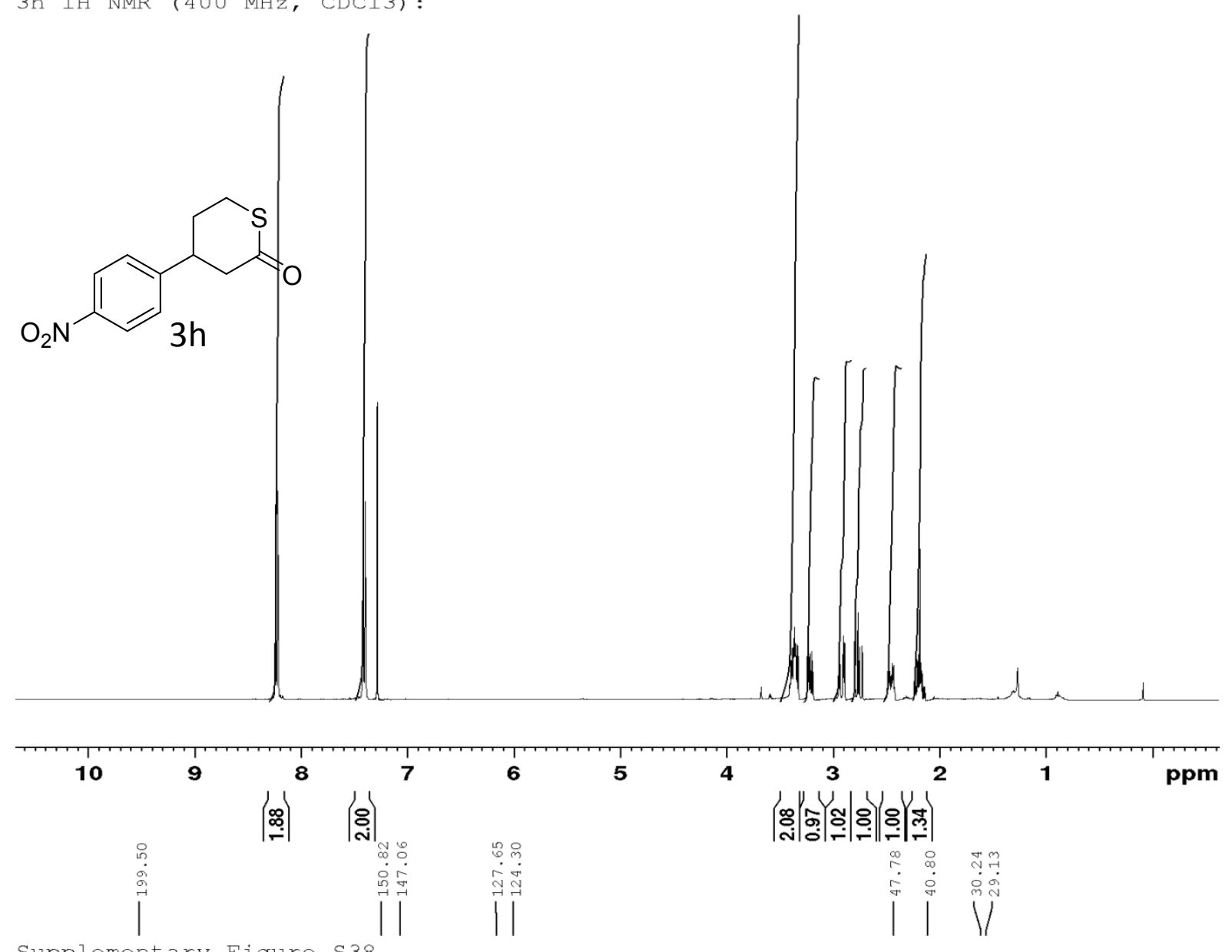

Supplementary Figure S38.

3h 13C NMR (101 MHz, CDCl3):<smiles>O=C1CC(c2ccc([SH+])cc2)CCS1</smiles>

$3 h$

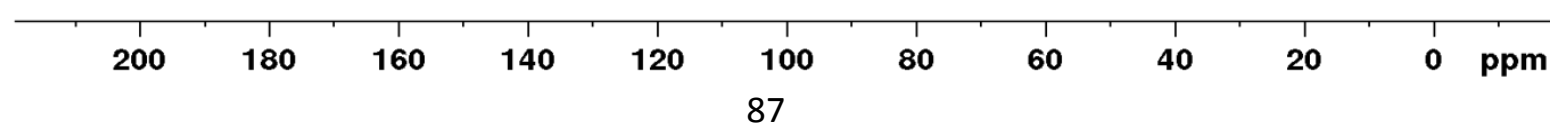




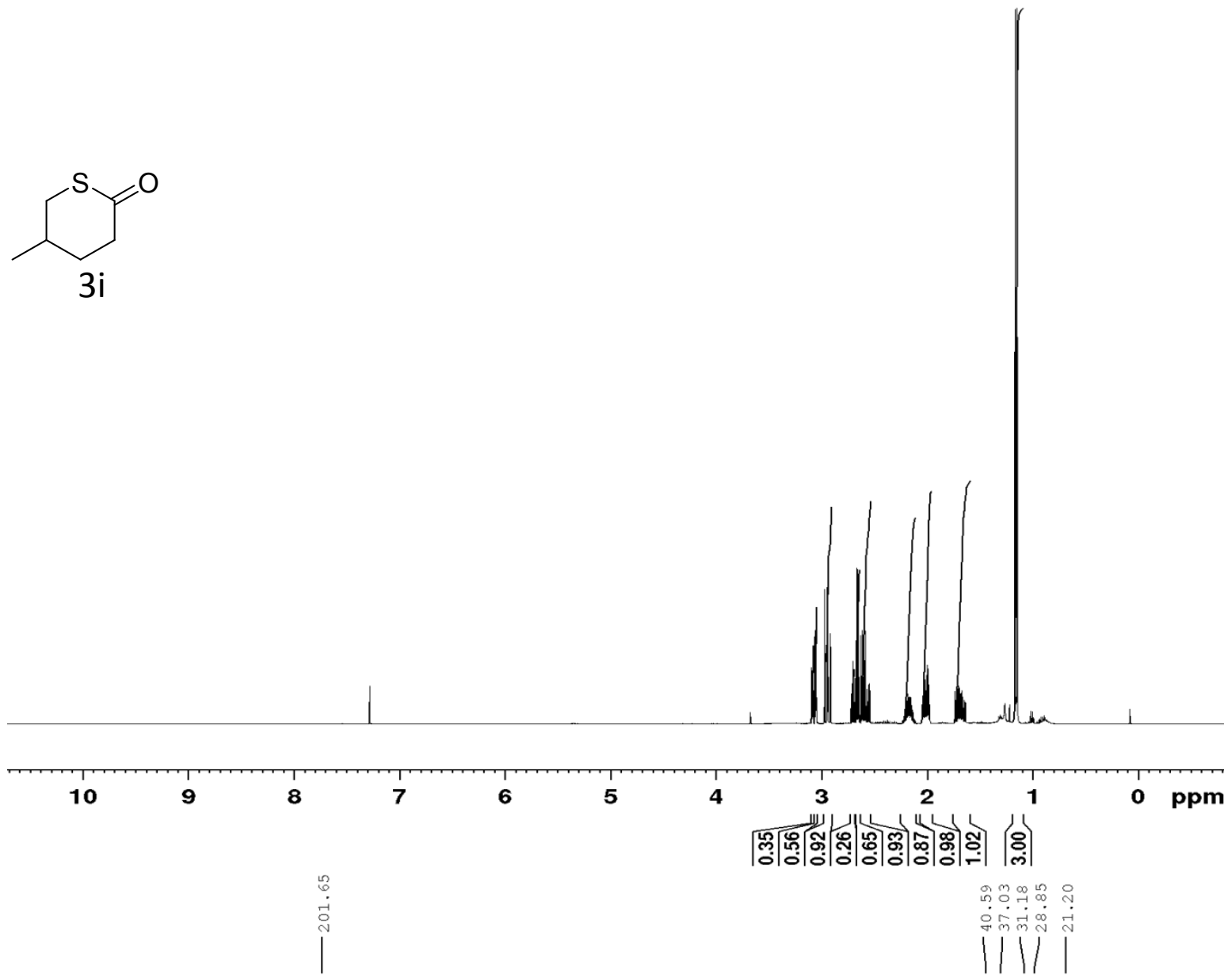

Supplementary Figure S39.

3i 13C NMR (101 MHz, CDCl3):<smiles>CC1CCC(=O)SC1</smiles>

$3 i$

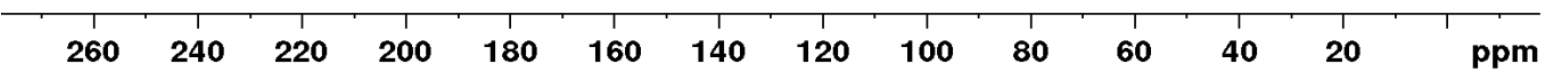




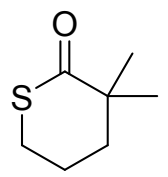

3j

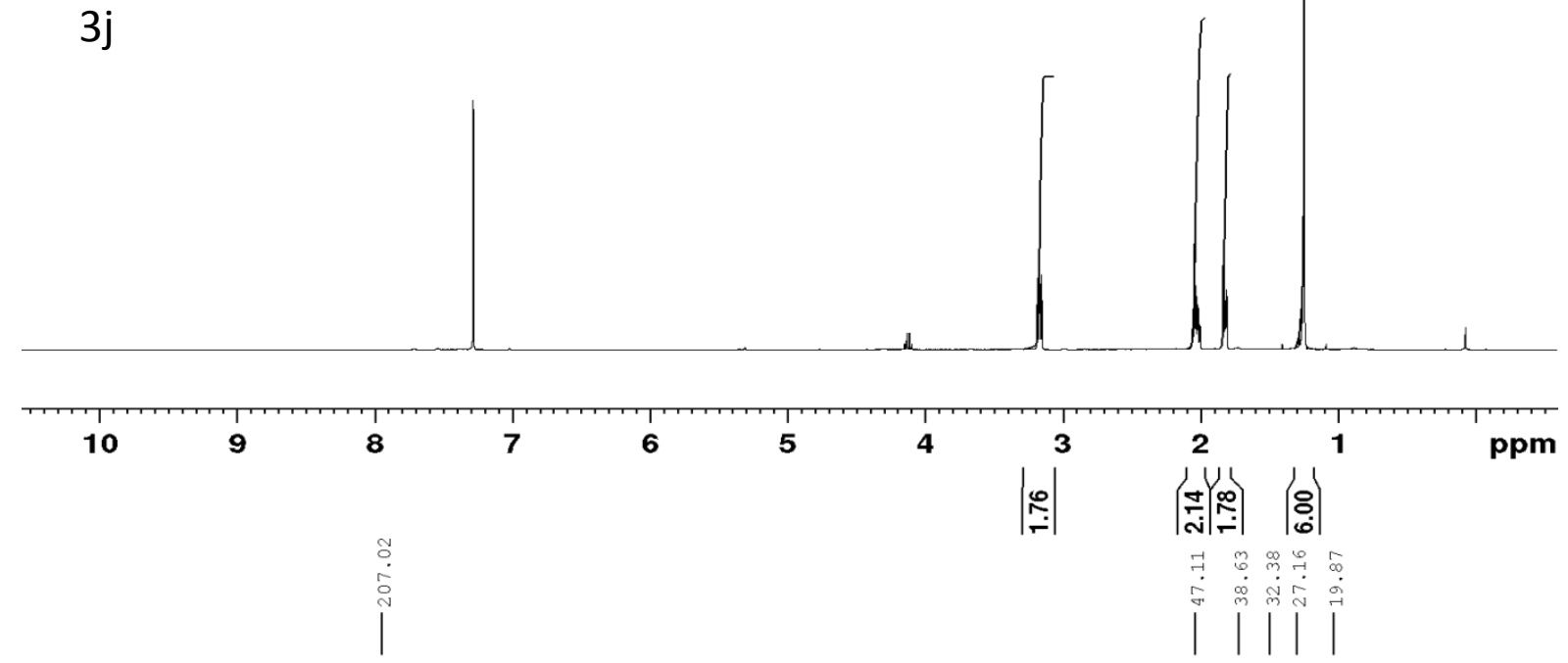

Supplementary Figure S40.

3j $1 \mathrm{H} \mathrm{NMR}$ ( $400 \mathrm{MHz}, \mathrm{CDCl} 3$ ):
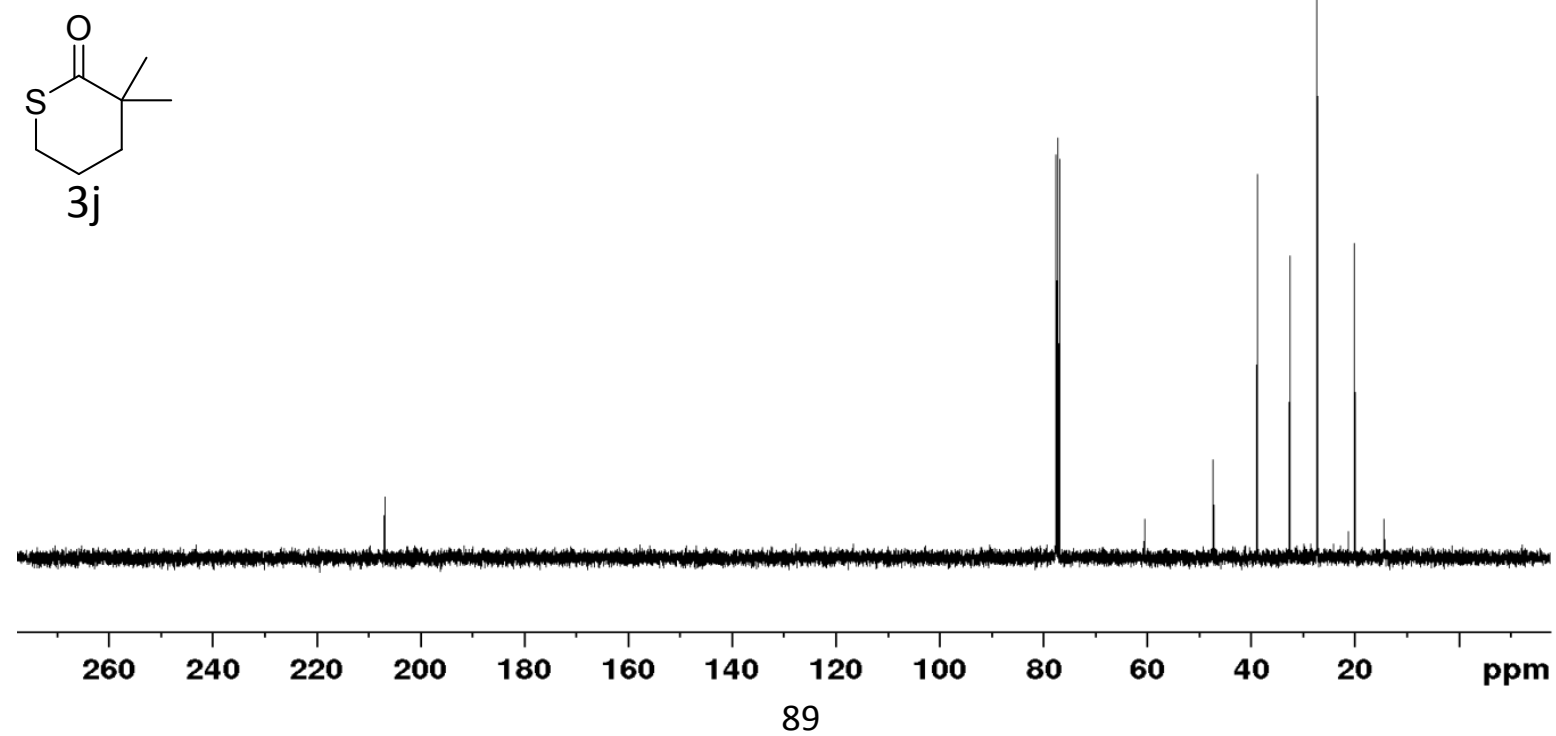

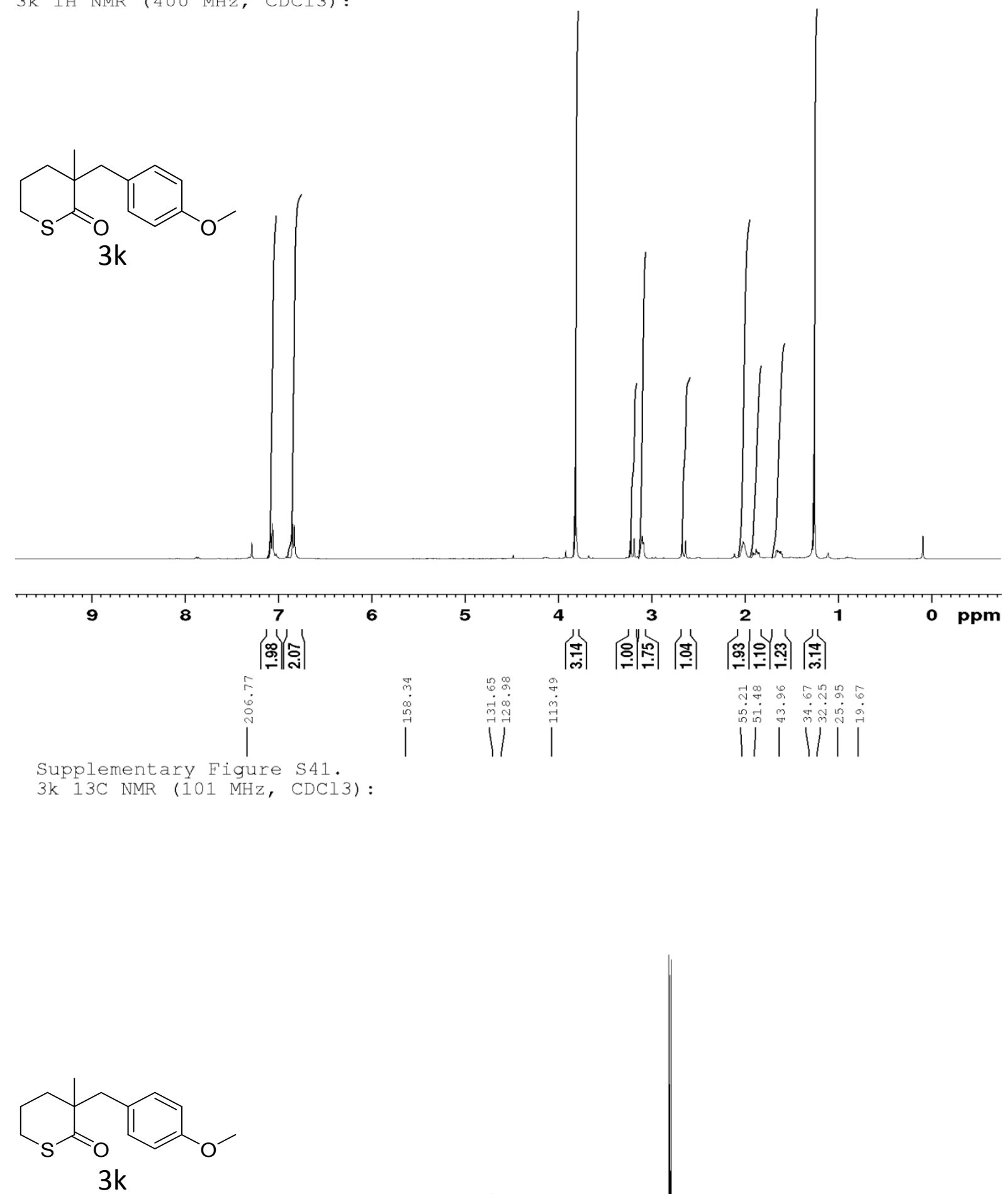

|(ฺ)
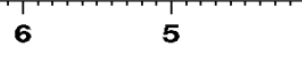

4

$43^{3}$

\section{2}

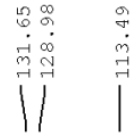

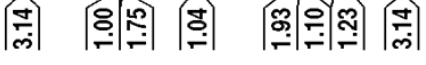

1

o ppm

-

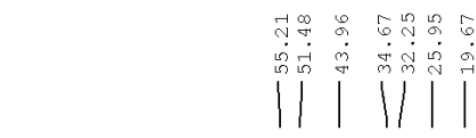

ili ili

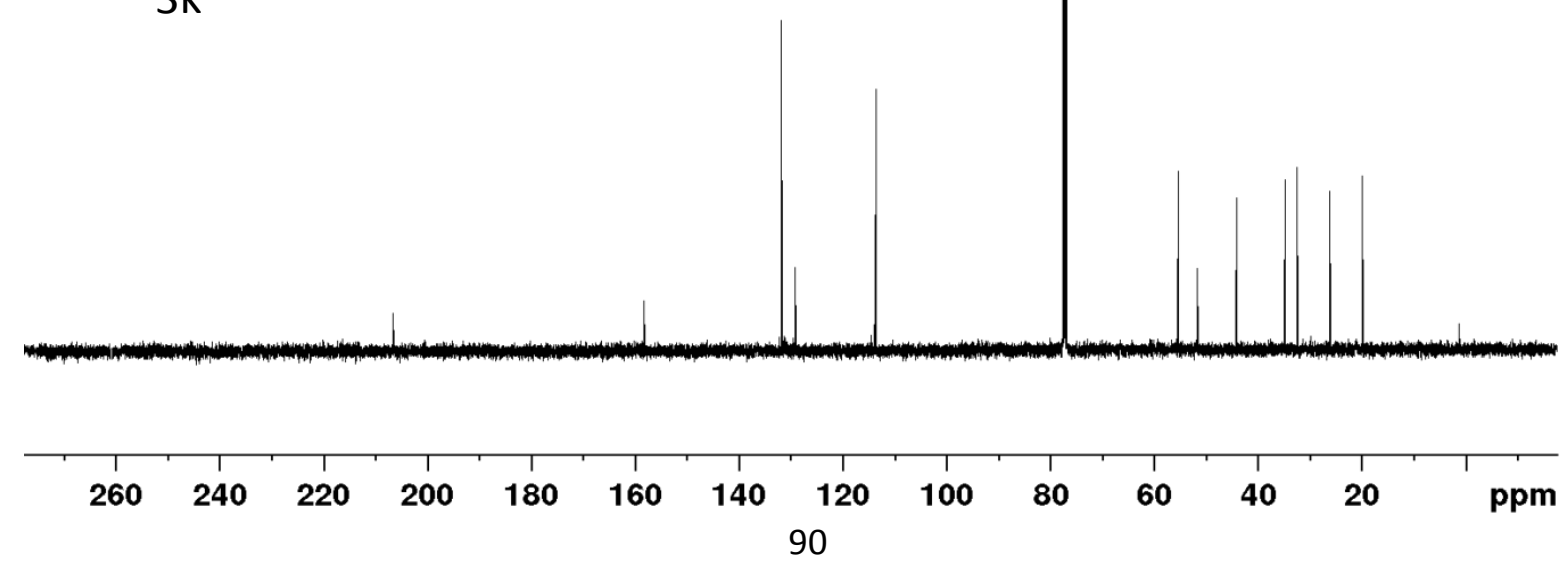




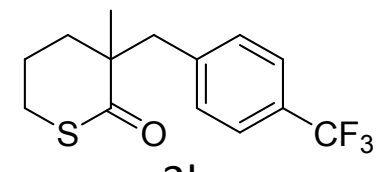

31
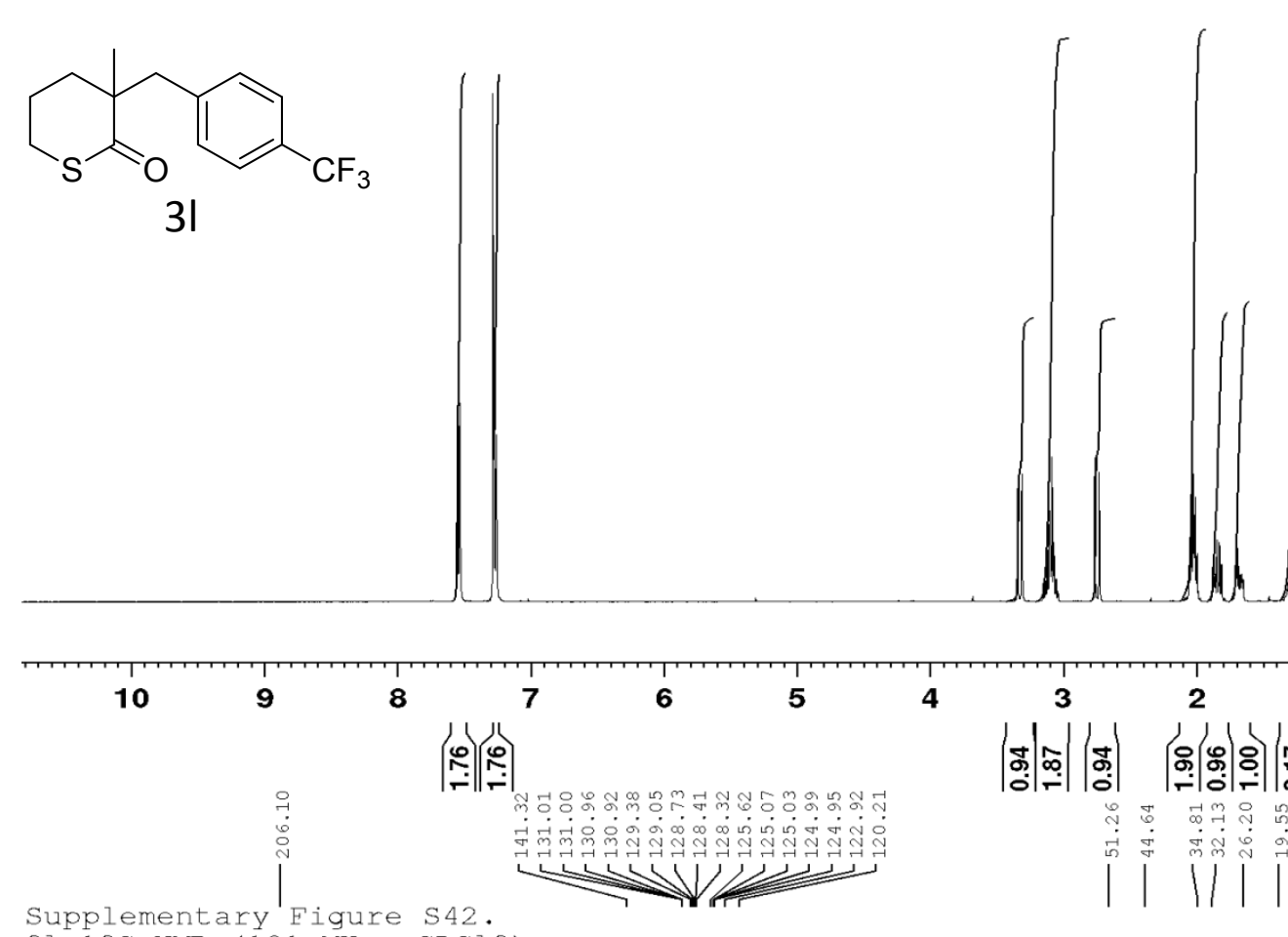

31 13C NMR (101 $\mathrm{MHz}, \mathrm{CDCl} 3$ ):

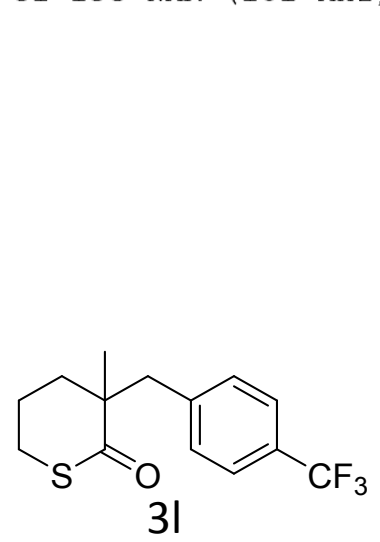

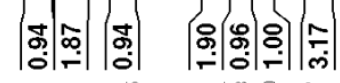

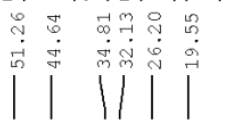




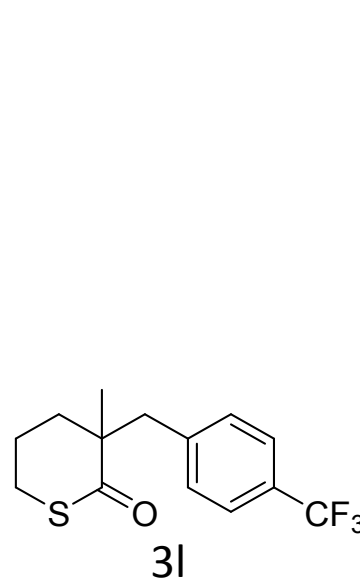



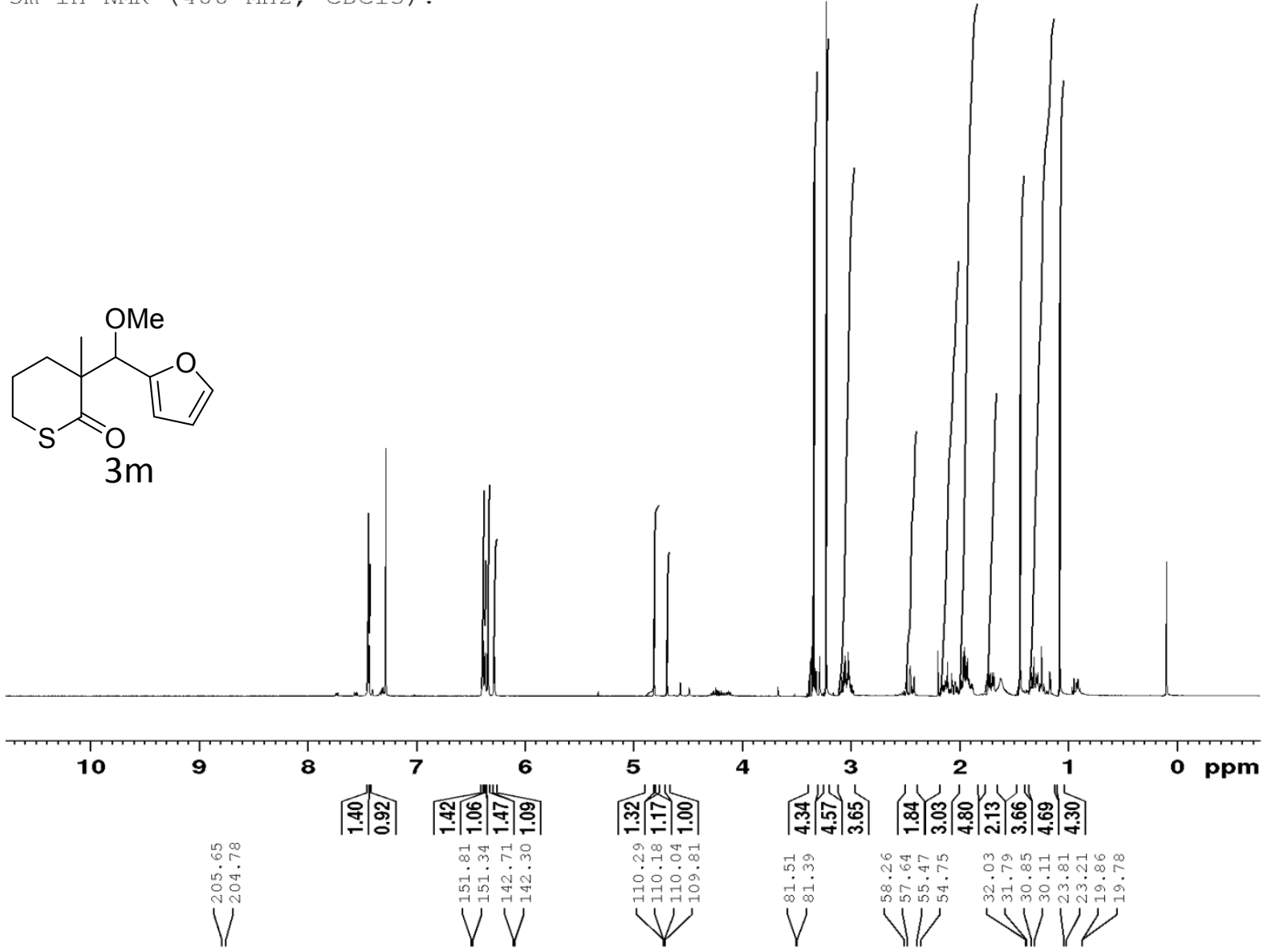

Supplementary Figure S43.

$3 \mathrm{~m}$ 13C NMR (101 $\mathrm{MHz}, \mathrm{CDCl} 3)$ :<smiles>COC(c1ccco1)C1(C)CCCSC1=O</smiles>

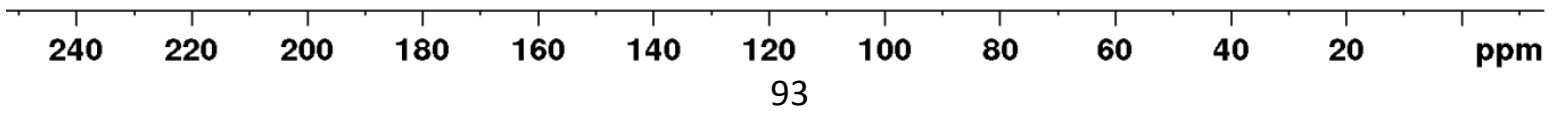




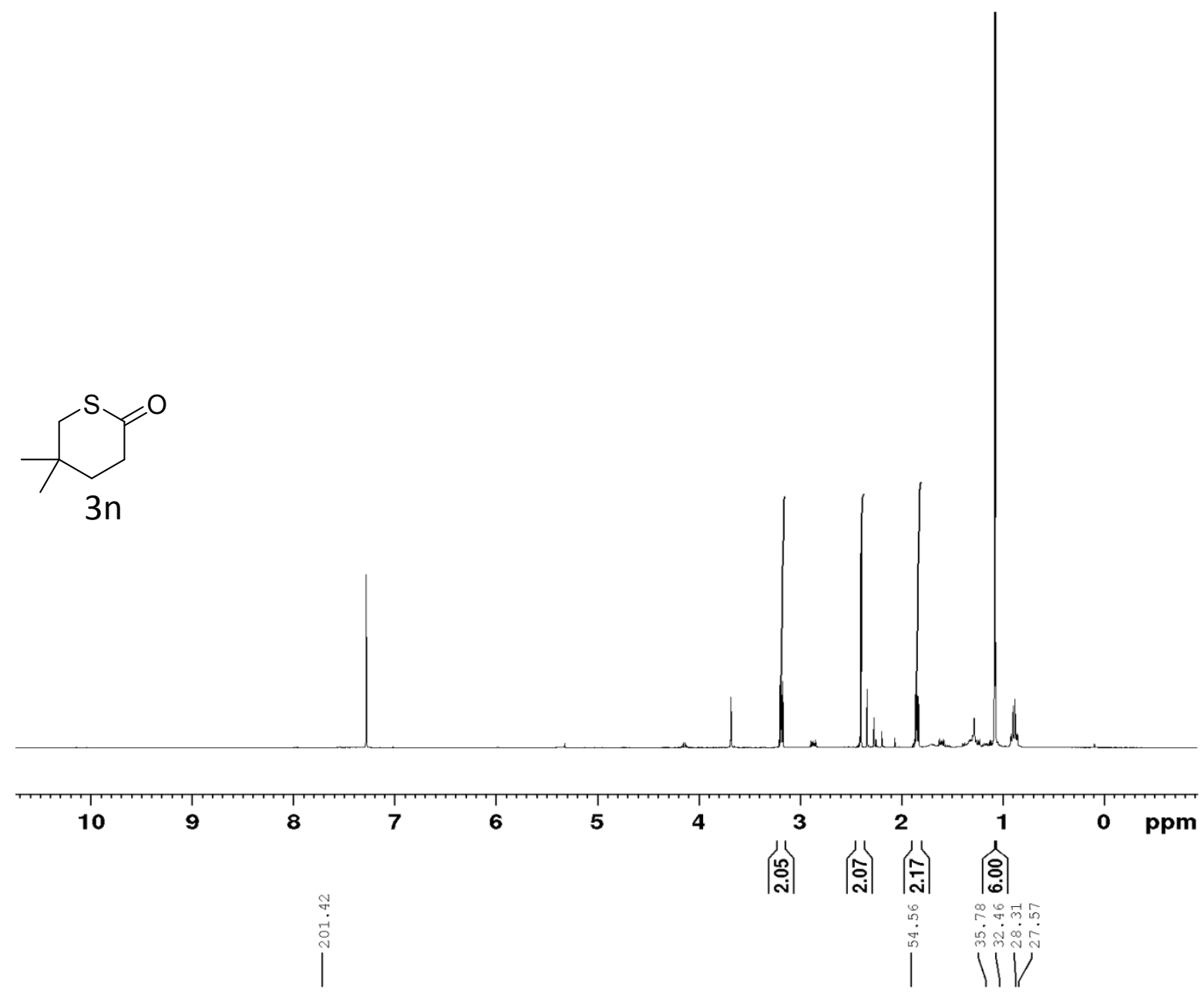

Supplementary Figure S44.

3n 13C NMR (101 $\mathrm{MHz}, \mathrm{CDCl} 3$ ):<smiles>CC1(C)CCC(=O)SC1</smiles>

$3 n$

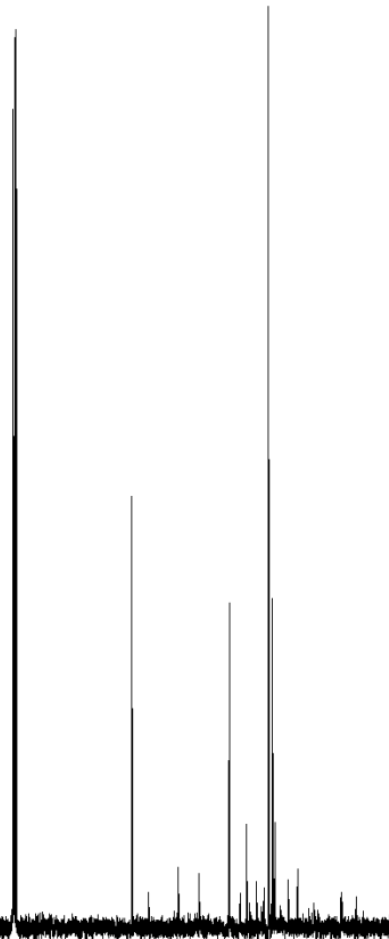

\begin{tabular}{lllllllllllllll}
\hline 260 & 240 & 220 & 200 & 180 & 160 & 140 & 120 & 100 & 80 & 60 & 40 & 20 & $\mathrm{ppm}$
\end{tabular}



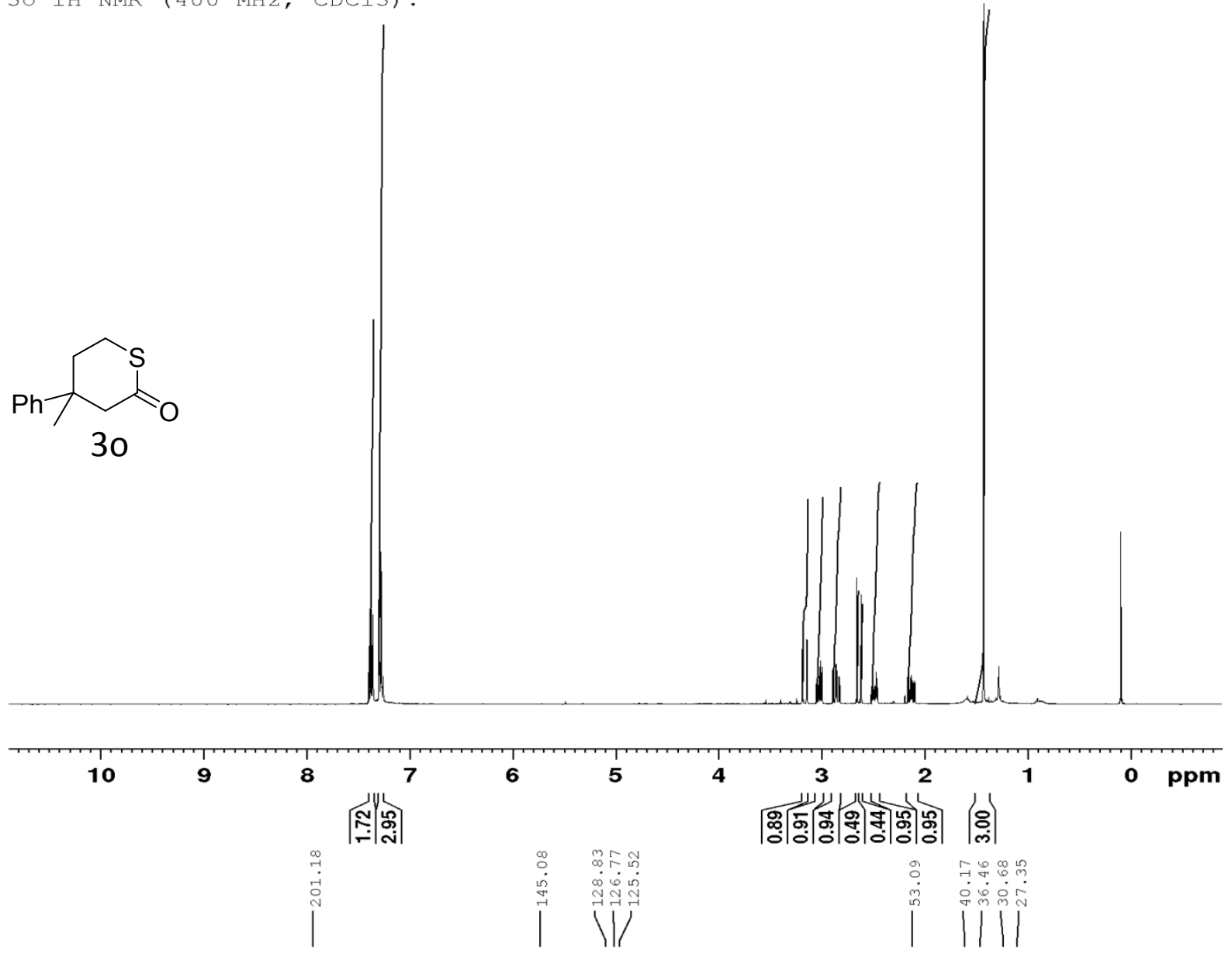

Supplementary Figure S45.

30 13C NMR (101 MHz, CDCl3):<smiles>CC1(c2ccccc2)CCSC(=O)C1</smiles>

\begin{tabular}{lllllllllllllll}
\hline 260 & 240 & 220 & 200 & 180 & 160 & 140 & 120 & 100 & 80 & 60 & 40 & 20 & $\mathrm{ppm}$
\end{tabular}




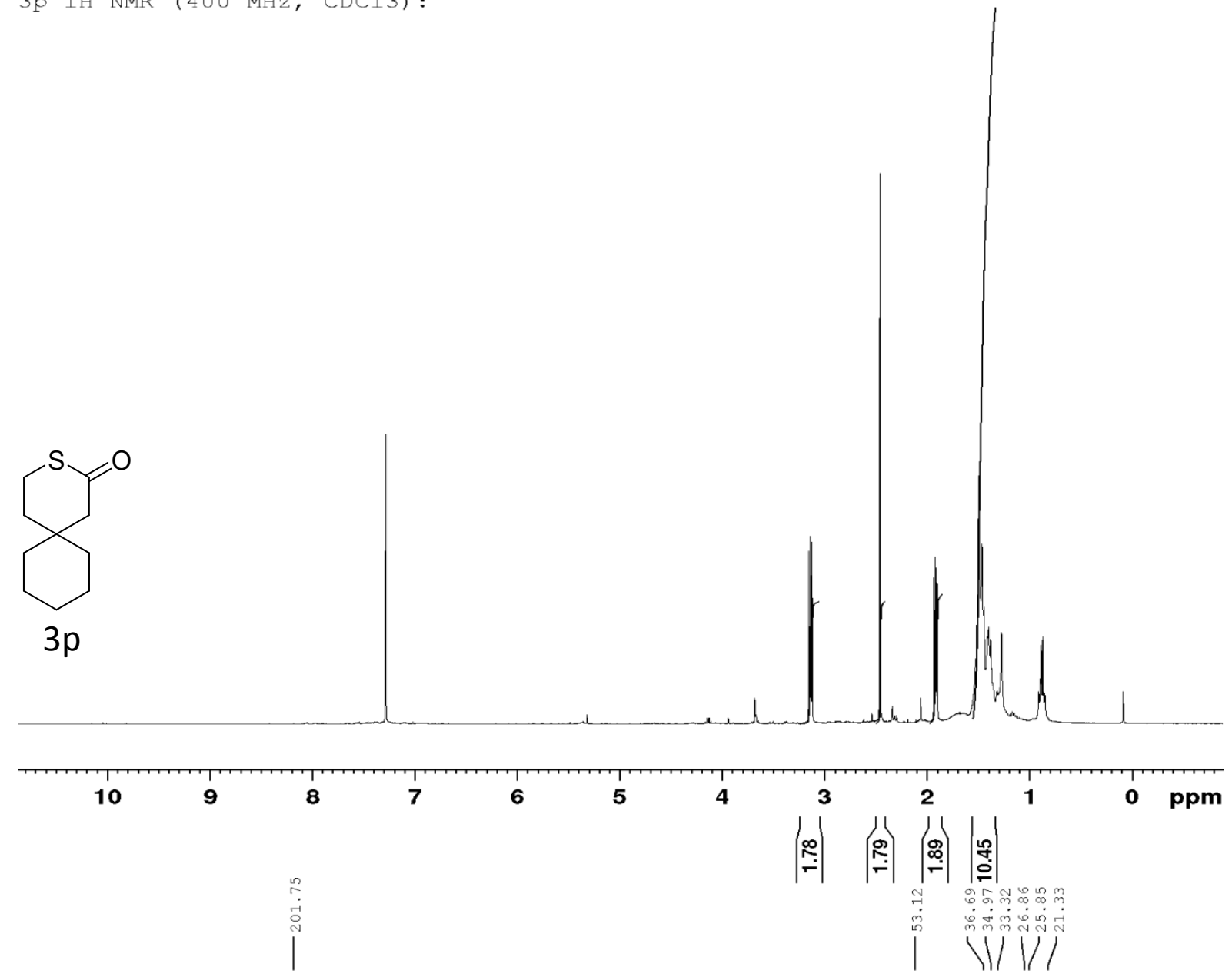

Supplementary Figure $\$ 46$.

3p 13C NMR (101 MHz, CDCl3):<smiles>O=C1CC2(CCCCC2)CCS1</smiles>
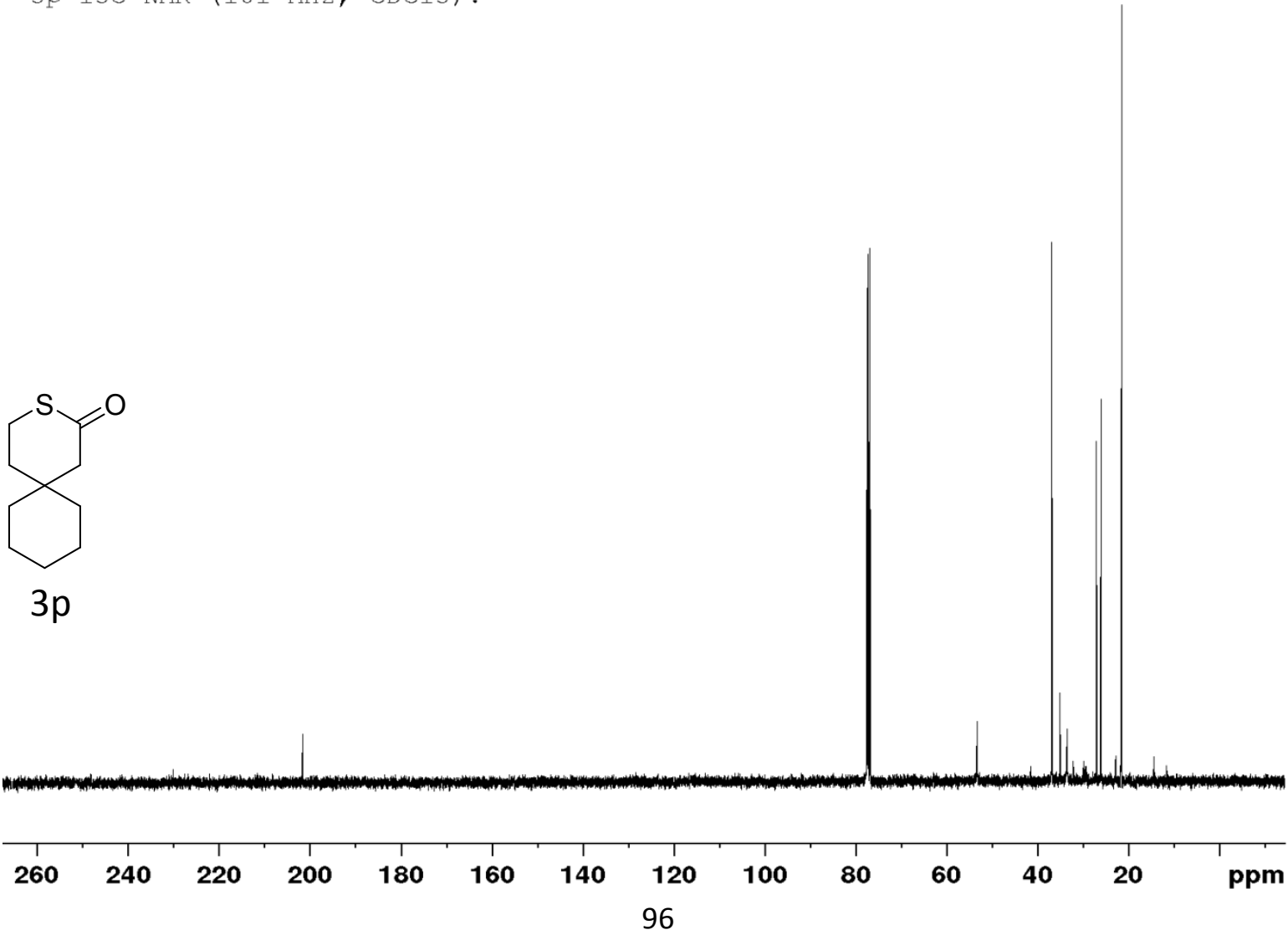


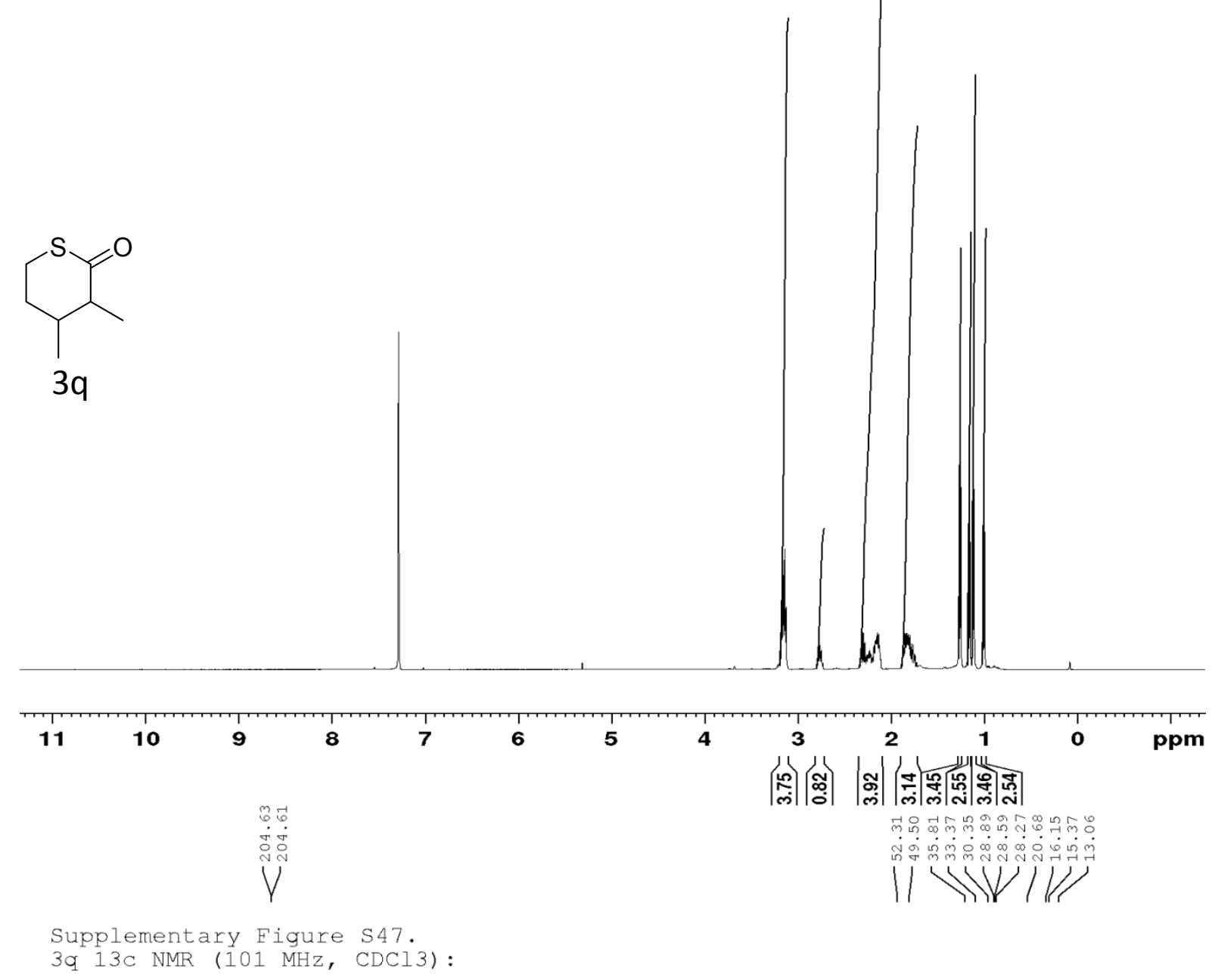<smiles>CC1C(=O)SCCC1[18O]</smiles> 

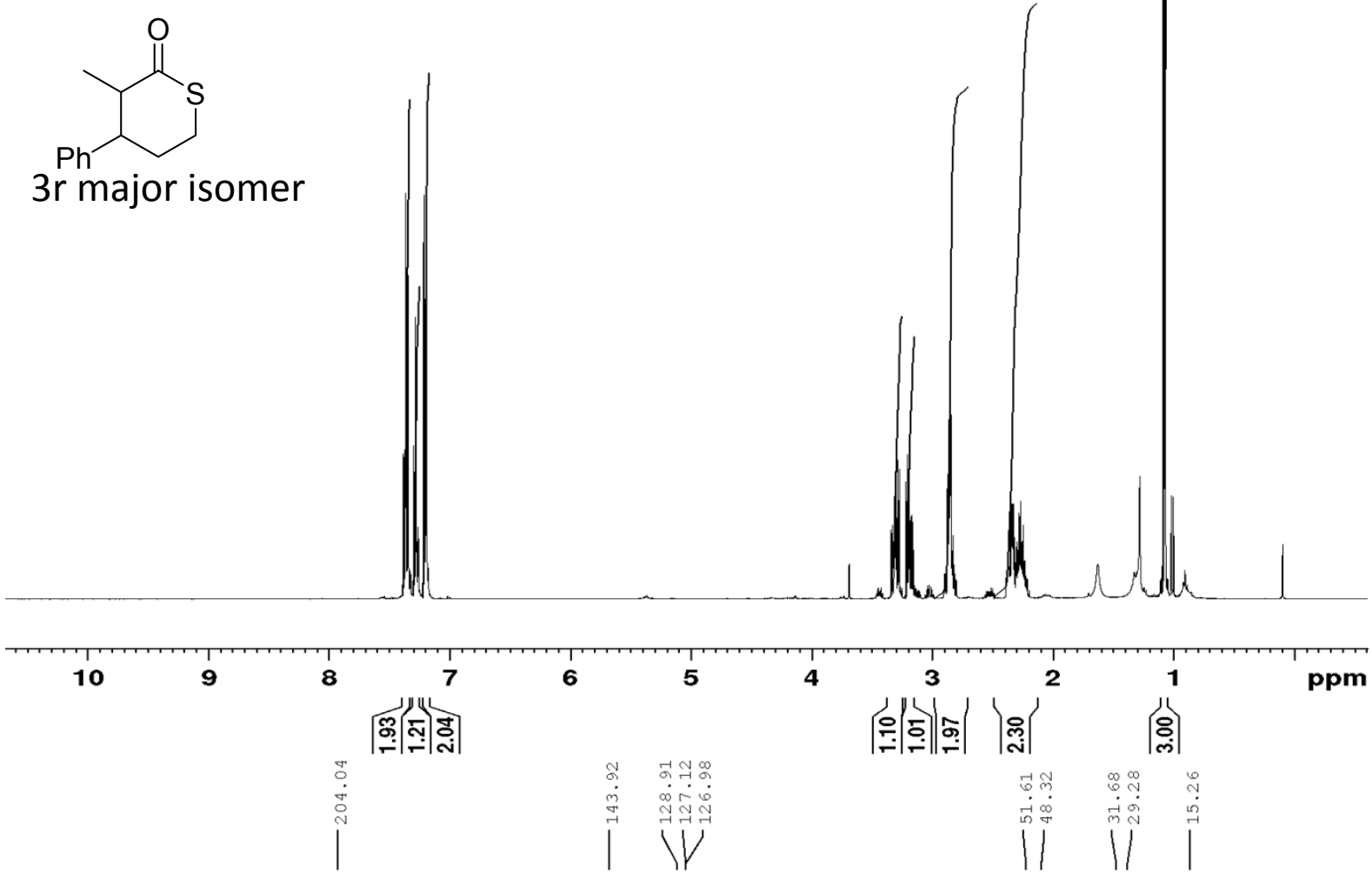

Supplementary Figure S48.

3r major isomer 13C NMR (101 MHz, CDCl3):

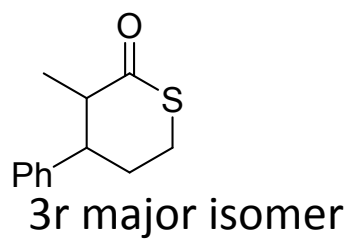

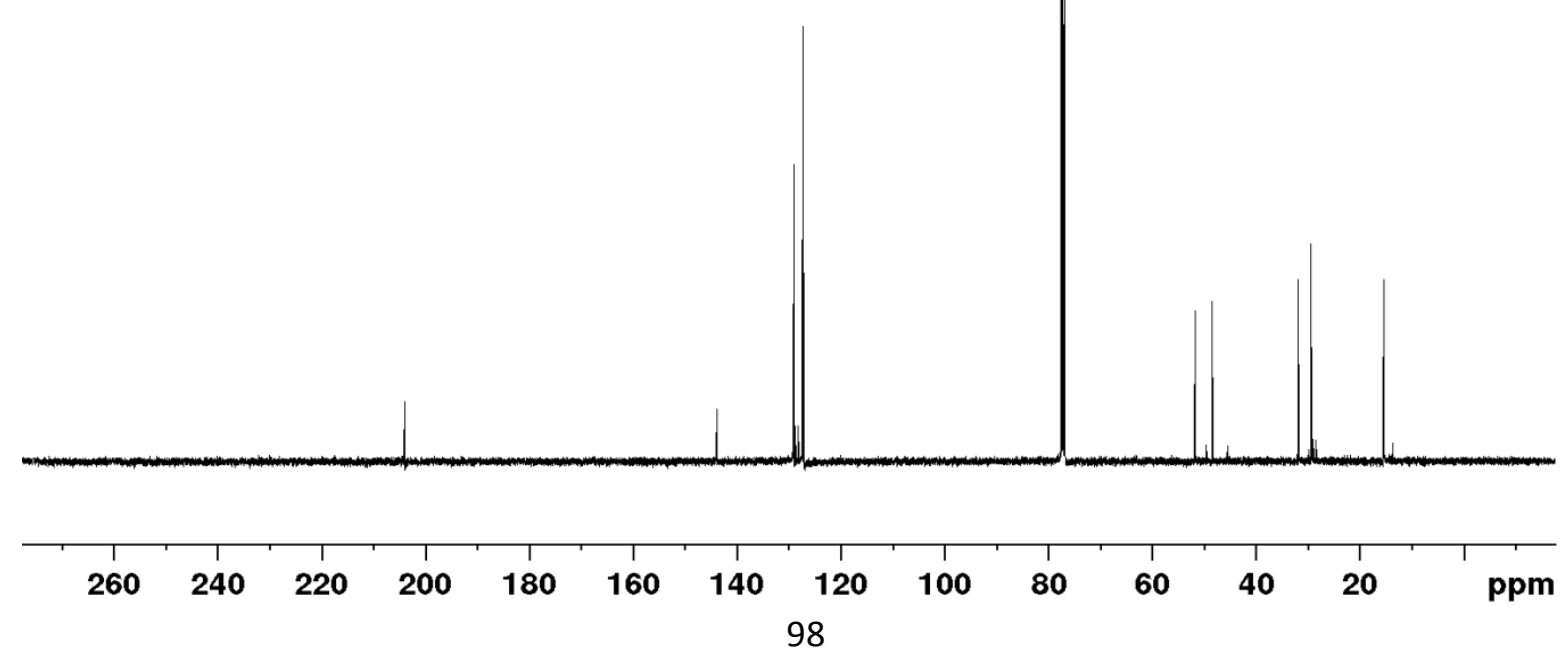


<smiles>CC1C(=O)SCCC1c1ccccc1</smiles>

\section{3r minor isomer}
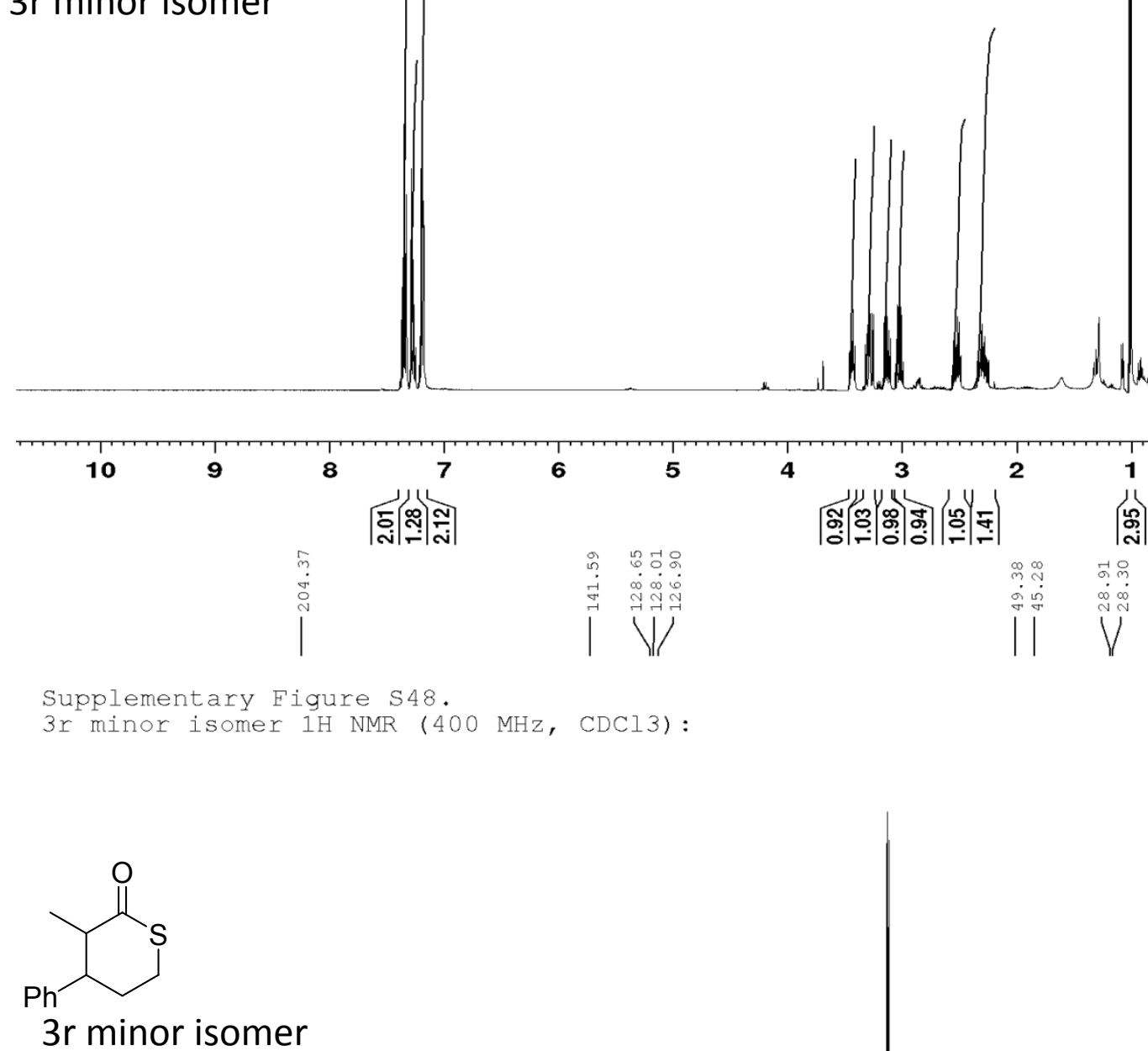

|ำ

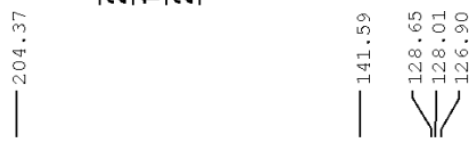

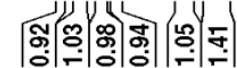

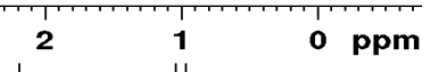

3r minor isomer

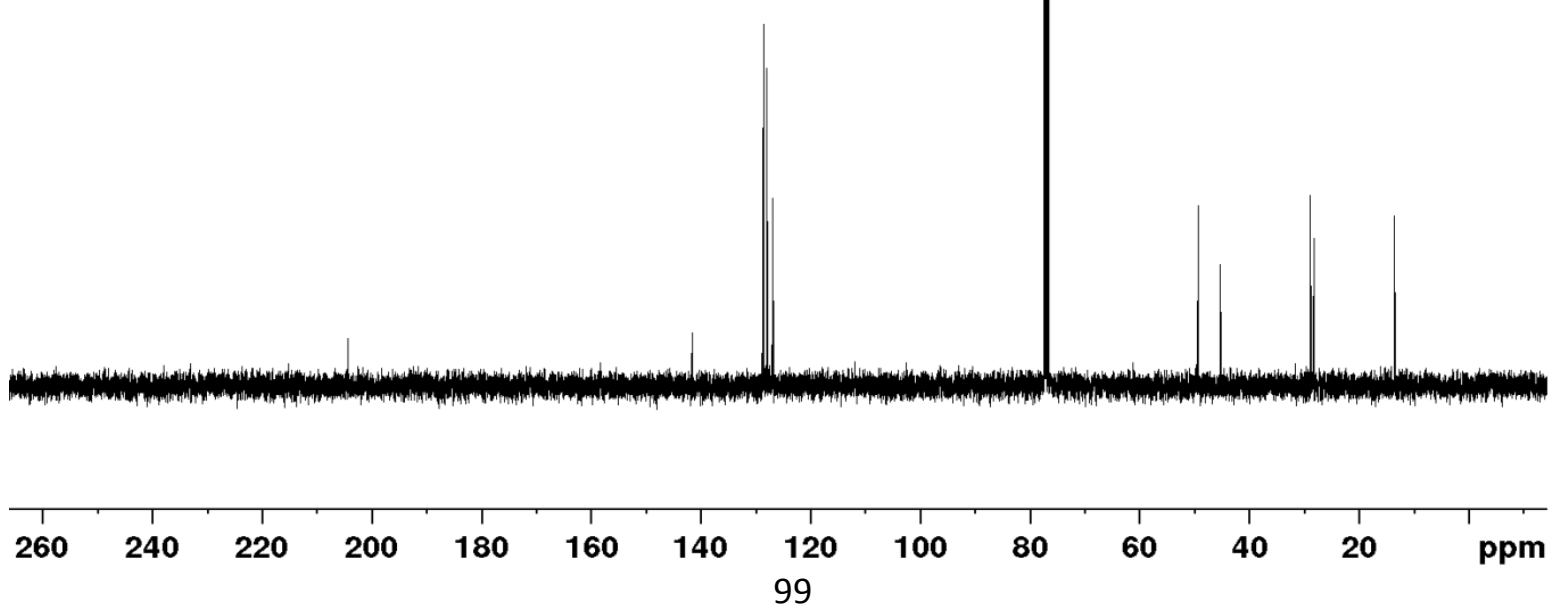




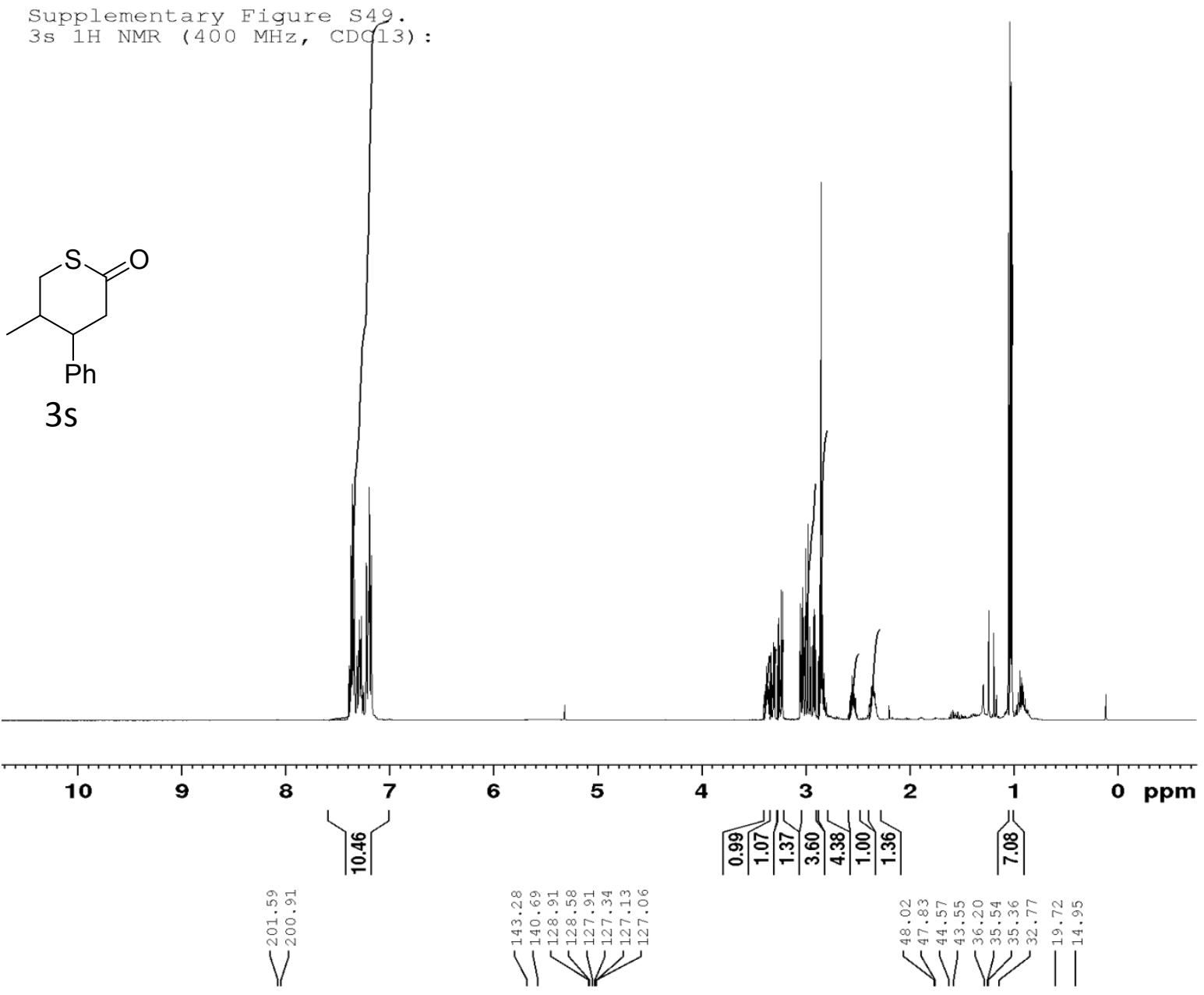

Supplementary Figure S49.

3s 13C NMR (101 MHz, CDCl3):<smiles>CC1CSC(=O)CC1Pc1ccccc1</smiles>

3s

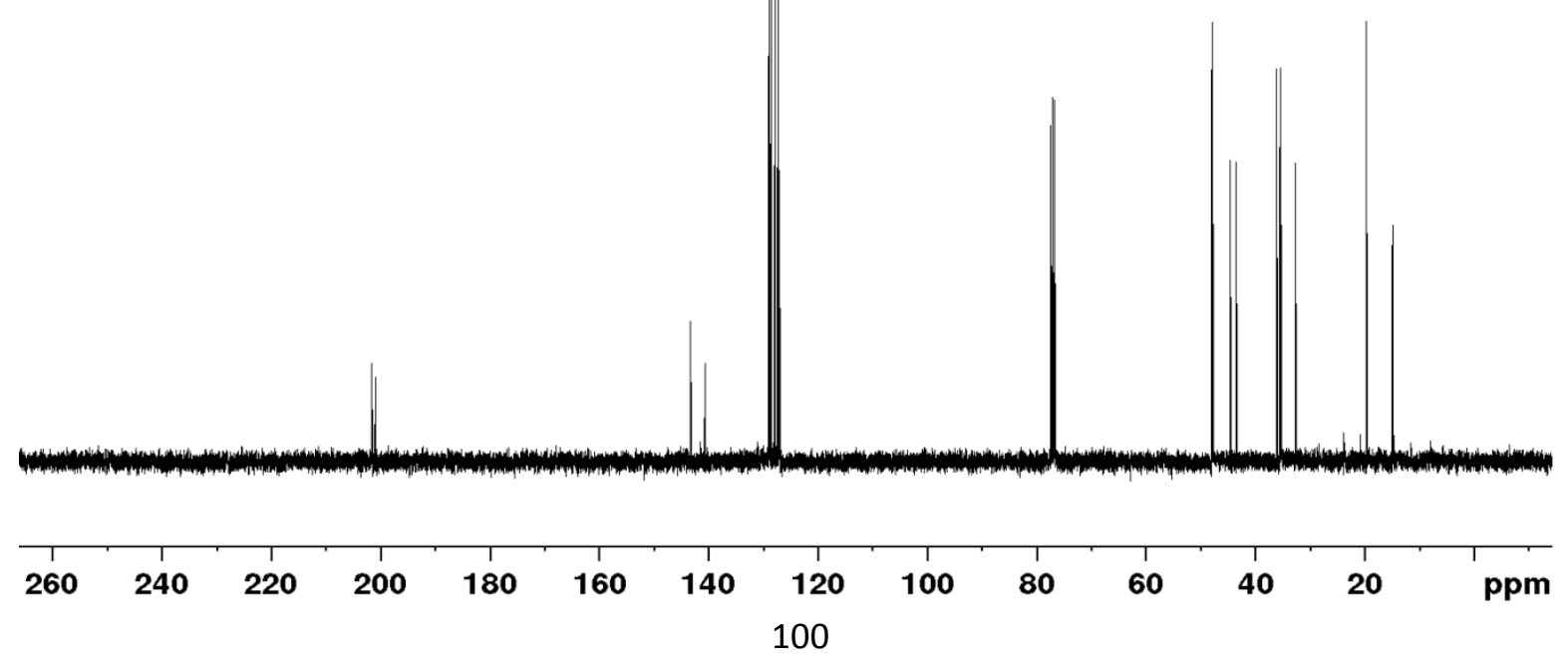




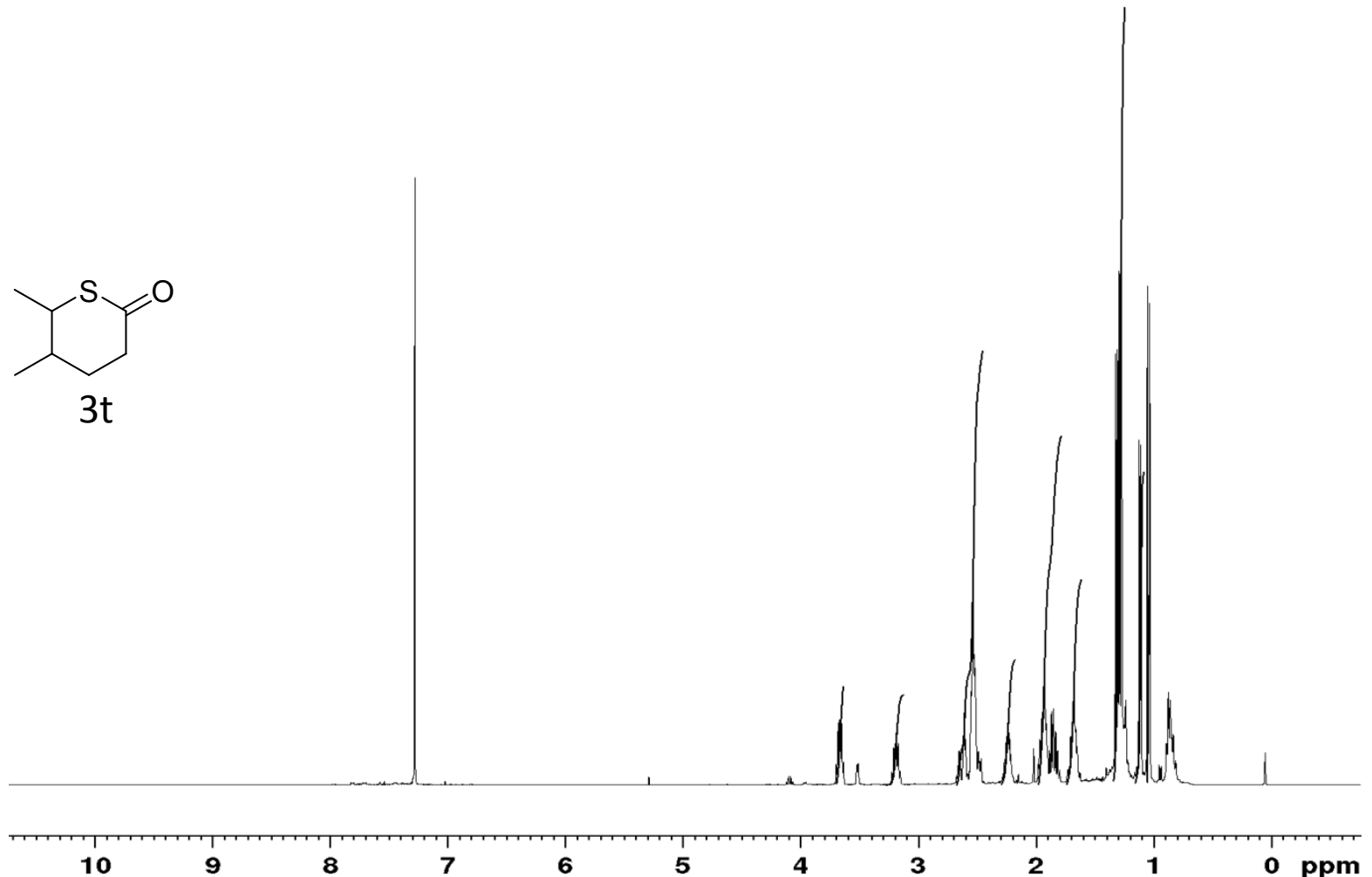

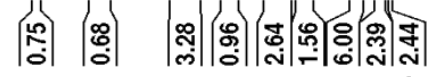

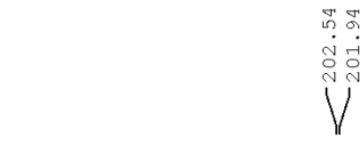

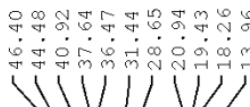

Supplementary Figure S50

3t $13 \mathrm{C} \mathrm{NMR} \mathrm{(101} \mathrm{MHz}, \mathrm{CDCl} 3)$ :<smiles>CC1SC(=O)CC(Br)C1C</smiles>

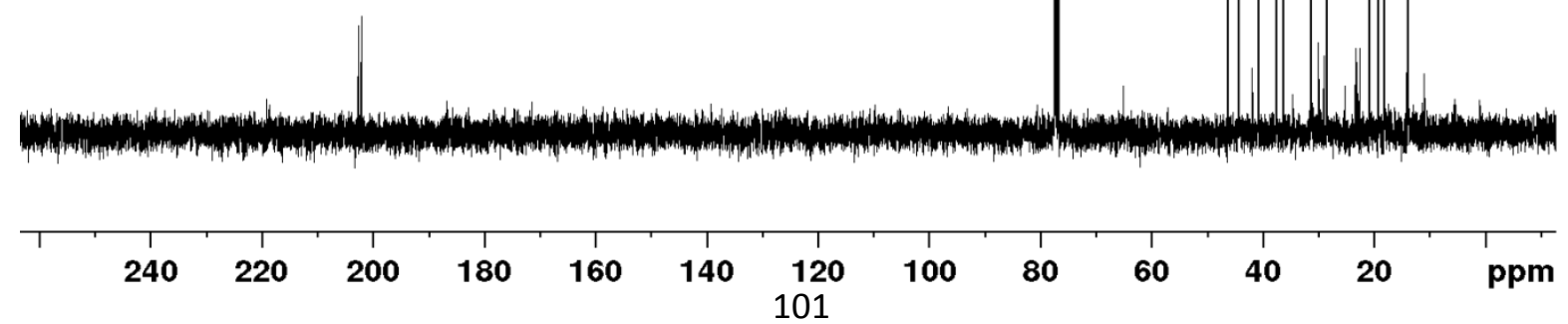




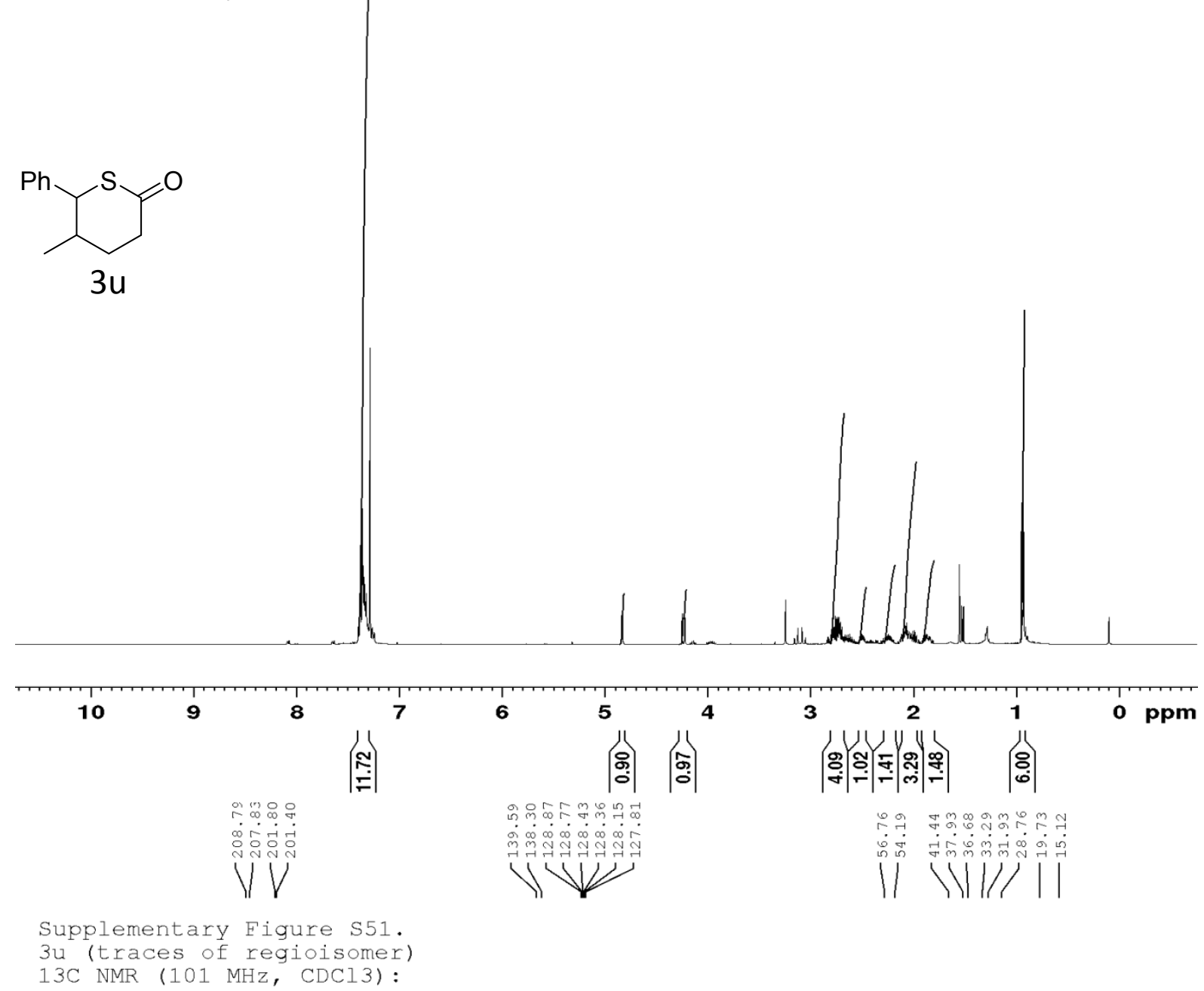<smiles>CC1CC(=O)SC(c2ccccc2)C1[Hg]</smiles>

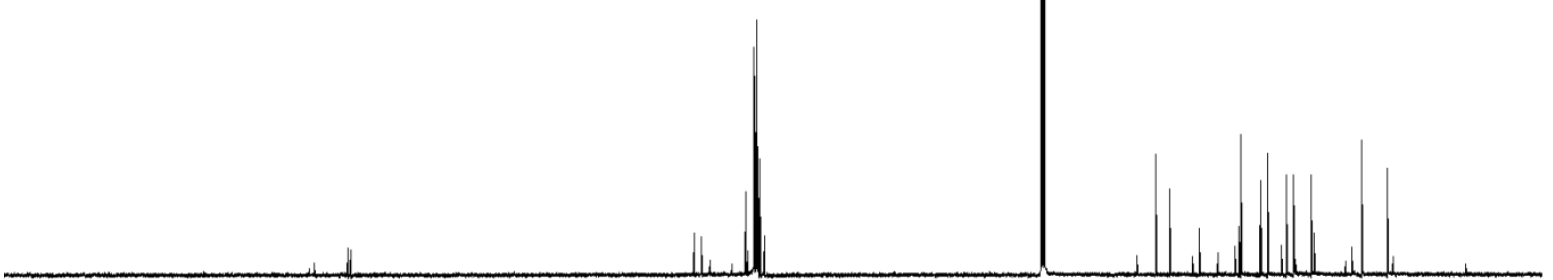

\begin{tabular}{lllllllllllll|l}
\hline 240 & 220 & 200 & 180 & 160 & 140 & 120 & 100 & 80 & 60 & 40 & 20 & ppm \\
\hline
\end{tabular}




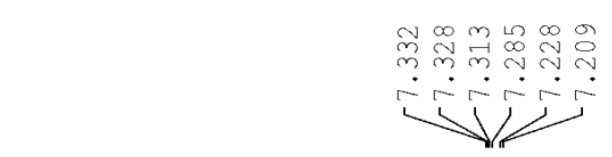

Supplementary Figure S52.

(400 $\mathrm{MHz}, \mathrm{CDCl} 3)$ :

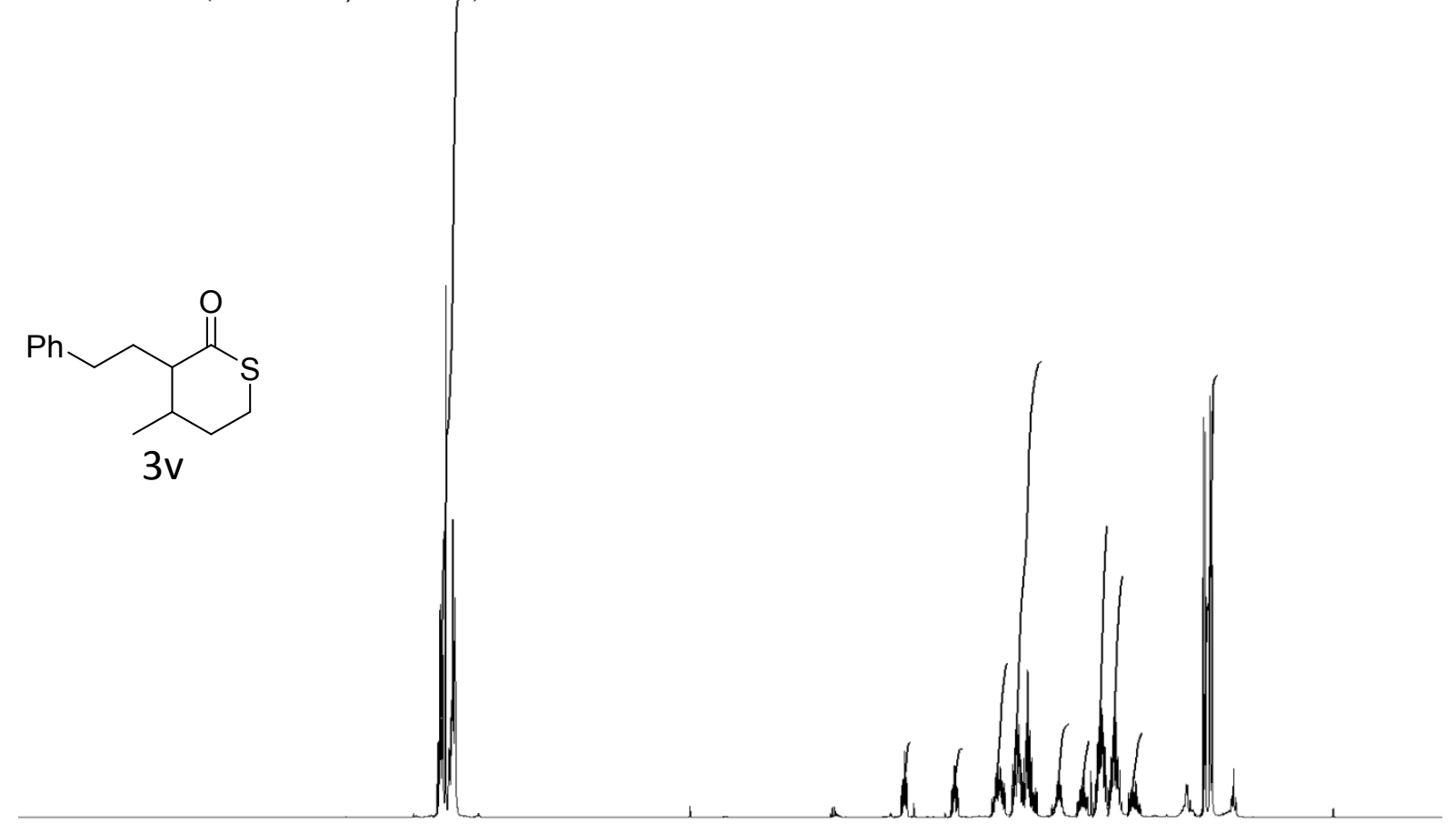

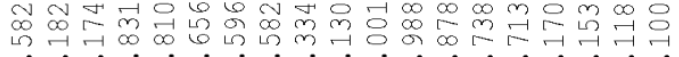

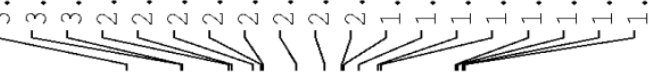
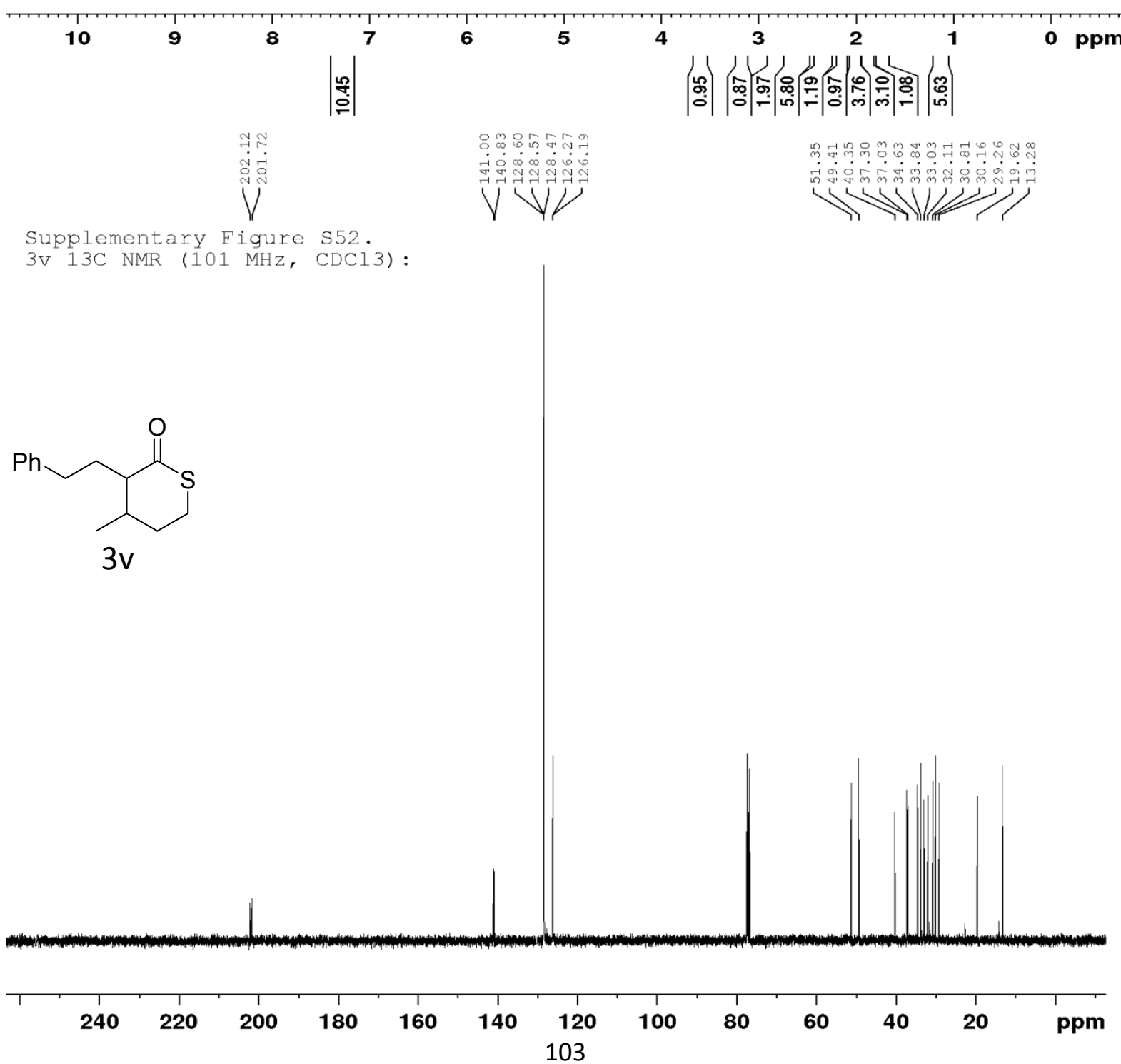


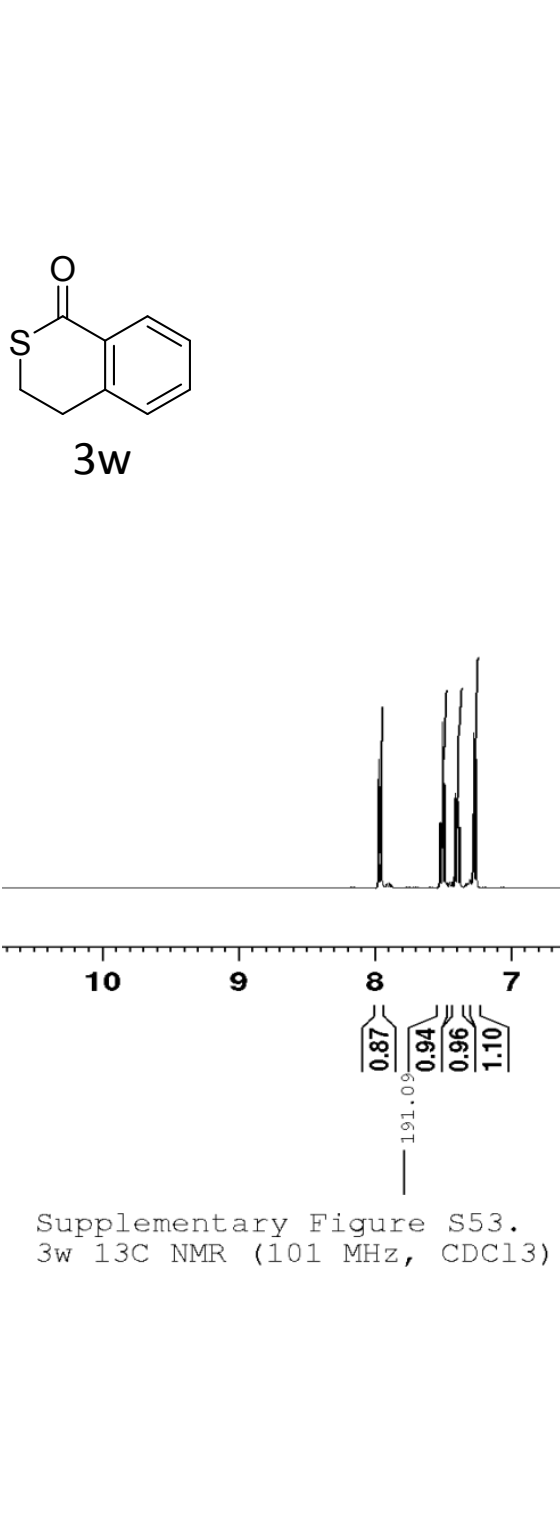

$3 w$
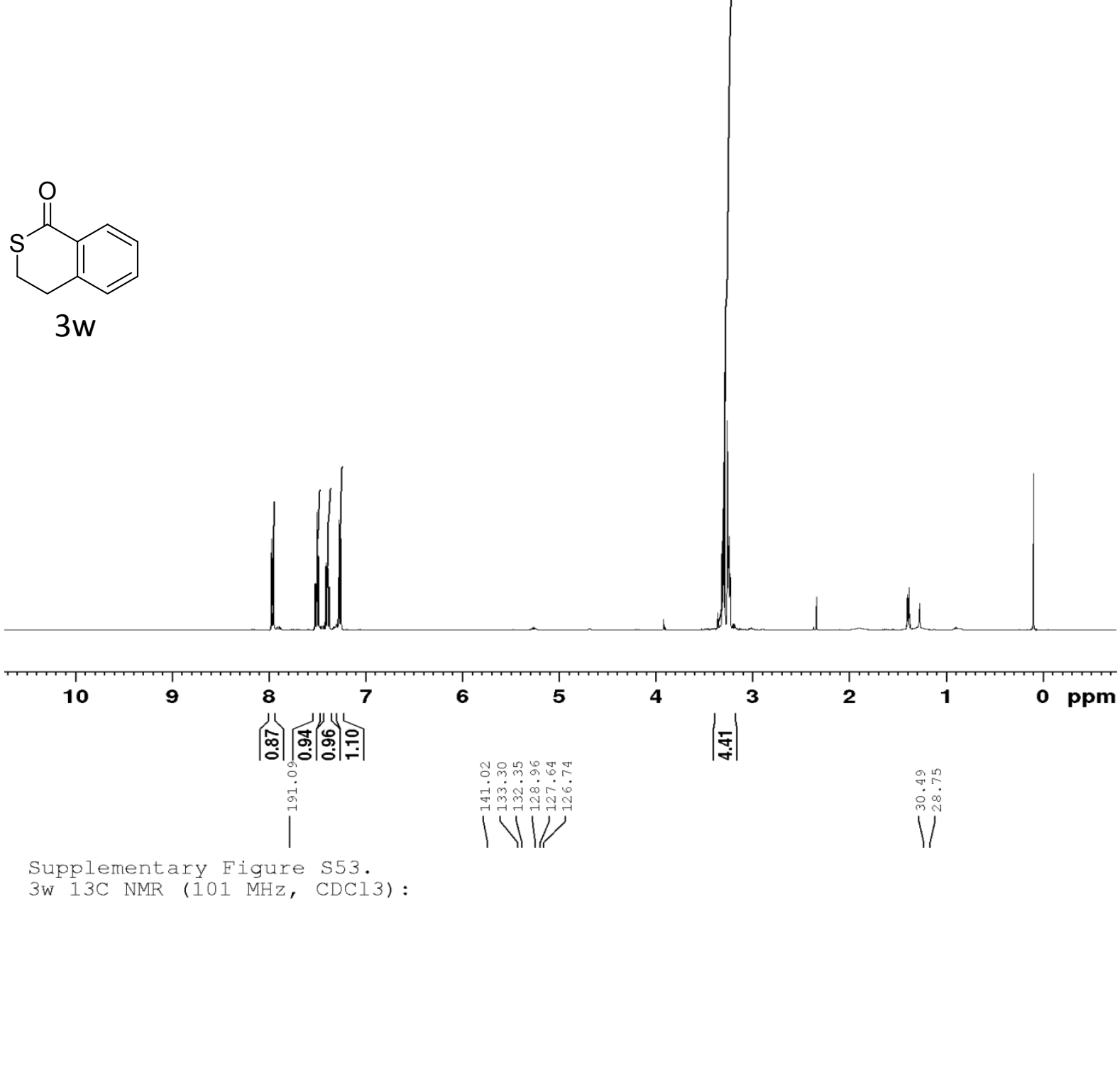

Supplementary Figure S53.

3w 13C NMR (101 MHz, CDCl3):<smiles>O=C1SCCc2ccccc21</smiles>

ww

240220

200 


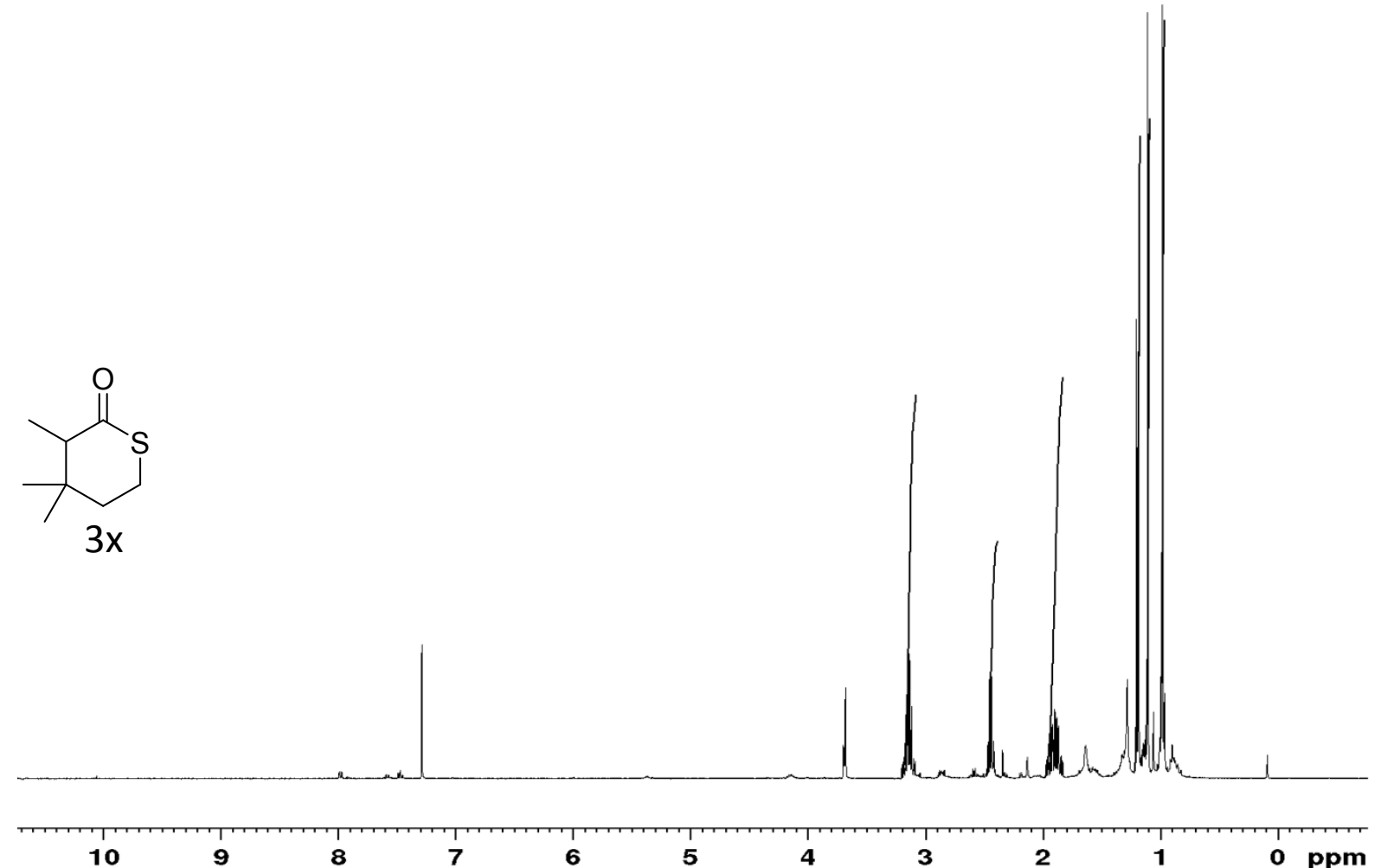

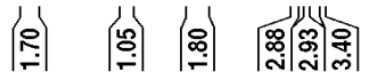
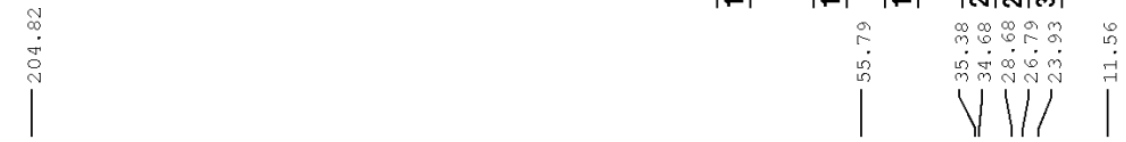

Supplementary Fiqure S54.

3x 13C NMR (101 MHz, CDCl3):<smiles>[X]C1(C)CCSC(=O)C1C</smiles>
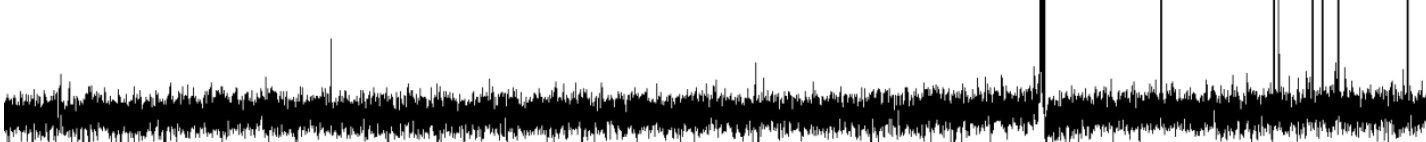

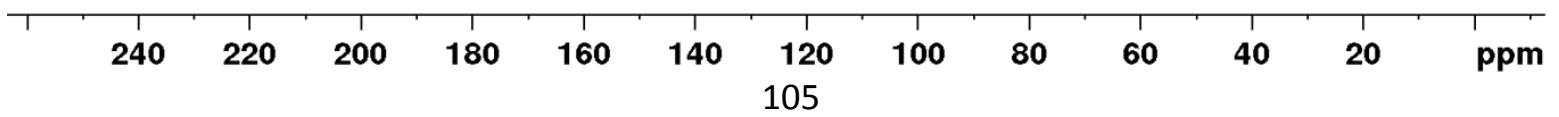



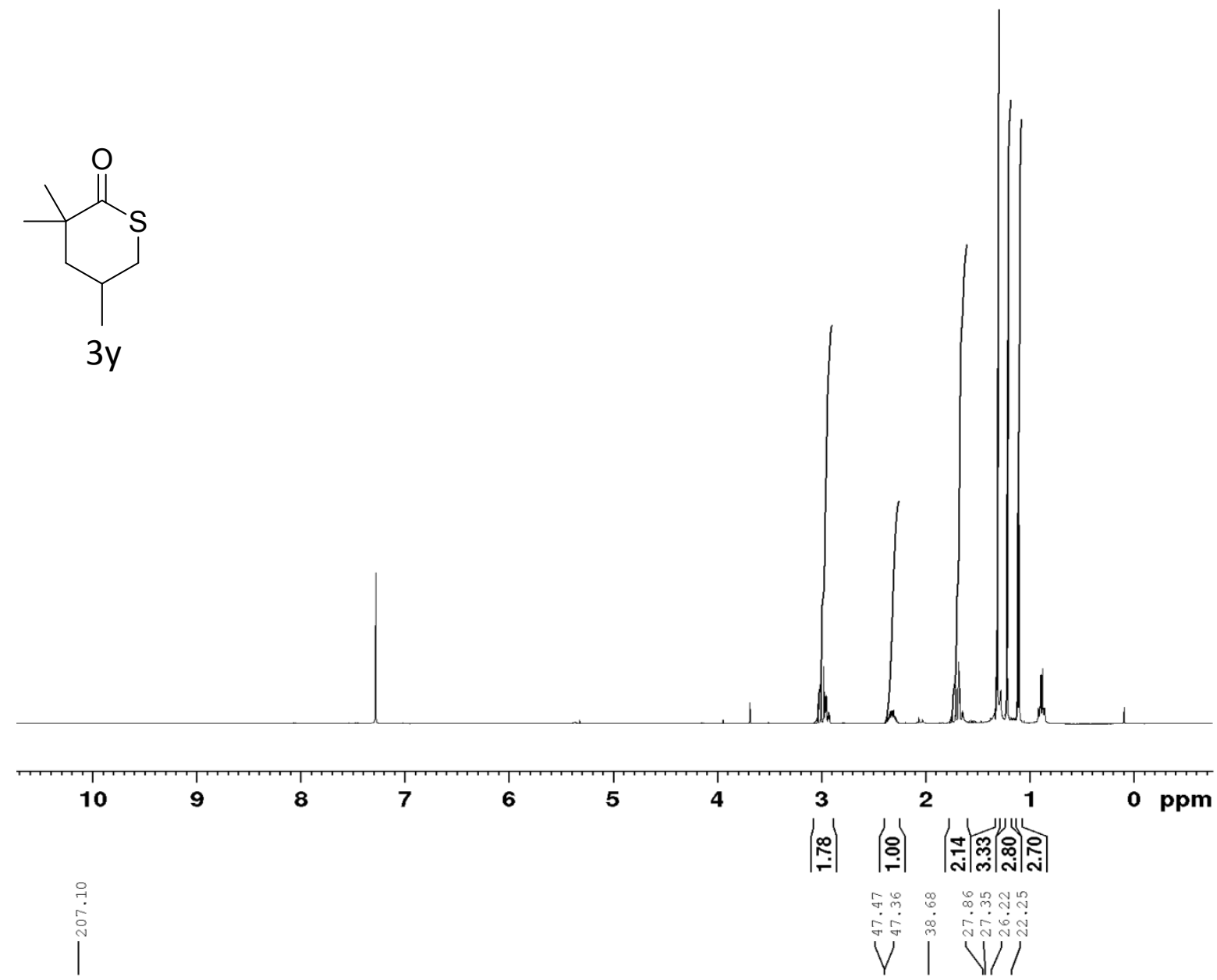

Supplementary Figure S55.

3y 13C NMR (101 MHz, CDCl3):<smiles>CC1(C)CC(Br)CSC1=O</smiles>

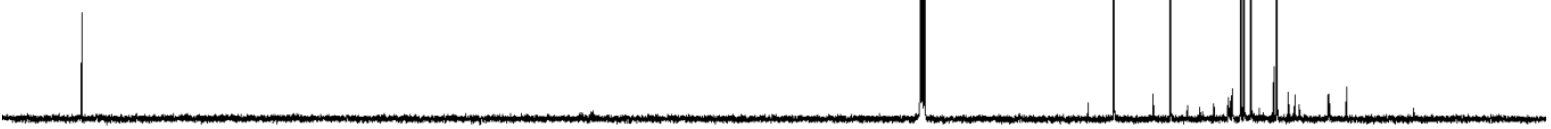




\section{References}

1. Fulmer, G. R.; Miller, A. J. M.; Sherden, N. H.; Gottlieb, H. E.; Nudelman, A.; Stoltz, B. M.; Bercaw, J. E.; Goldberg, K. I. Organometallics 2010, 29, 2176-2179.

2. Ito, T.; Overman, L. E.; Wang, J. J. Am. Chem. Soc. 2010, 132, 3272-3273.

3. Kiyotsuka, Y.; Acharya, H. P.; Katayama, Y.; Hyodo, T.; Kobayashi, Y. Org. Lett. 2008, 10, 17191722.

4. Podunavac, M.; Lacharity, J. J.; Jones, K. E.; Zakarian, A. Org. Lett. 2018, 20, 4867-4870.

5. Takacs, J. M.; Myoung, Y.-C.; Anderson, L. G. J. Org. Chem. 1994, 59, 6928-6942.

6. $\quad$ Appel, R.; Loos, R.; Mayr, H. J. Am. Chem. Soc. 2009, 131, 704-714.

7. Spoehrle, S. S. M.; West, T. H.; Taylor, J. E.; Slawin, A. M. Z.; Smith, A. D. J. Am. Chem. Soc. 2017, 139, 11895-11902.

8. Devalankar, D. A.; Karabal, P. U.; Sudalai, A. Org. Biomol. Chem. 2013, 11, 1280-1285.

9. Bouziane, A.; Hélou, M.; Carboni, B.; Carreaux, F.; Demerseman, B.; Bruneau, C.; Renaud, J.-L. Chem. Eur. J. 2008, 14, 5630-5637.

10. Avery, T. D.; Caiazza, D.; Culbert, J. A.; Taylor, D. K.; Tiekink, E. R. T. J. Org. Chem. 2005, 70, 8344-8351.

11. Pal, S.; Lucarini, F.; Ruggi, A.; Kilbinger, A. F. M. J. Am. Chem. Soc. 2018, 140, 3181-3185.

12. Miyata, K.; Kutsuna, H.; Kawakami, S.; Kitamura, M. Angew. Chem. Int. Ed. 2011, 50, 46494653.

13. Fernández-Mateos, A.; Herrero Teijón, P.; Mateos Burón, L.; Rabanedo Clemente, R.; Rubio González, R. J. Org. Chem. 2007, 72, 9973-9982.

14. Wender, P. A.; Koehler, M. F. T.; Sendzik, M. Org. Lett. 2003, 5, 4549-4552.

15. Piemontesi, C.; Wang, Q.; Zhu, J. J. Am. Chem. Soc. 2016, 138, 11148-11151.

16. Liu, R.; Yang, Z.; Ni, Y.; Song, K.; Shen, K.; Lin, S.; Pan, Q. J. Org. Chem. 2017, 82, 8023-8030.

17. Zhang, P.; Le, H.; Kyne, R. E.; Morken, J. P. J. Am. Chem. Soc. 2011, 133, 9716-9719.

18. Srikrishna, A.; Ramasastry, S. S. V. Tetrahedron Lett. 2004, 45, 379-382.

19. Comito, R. J.; Finelli, F. G.; MacMillan, D. W. C. J. Am. Chem. Soc. 2013, 135, 9358-9361.

20. Li, W.; Moeller, K. D. J. Am. Chem. Soc. 1996, 118, 10106-10112.

21. Sebastian, M. T. Syn. Commun. 1991, 21, 581-586.

22. Arnold, R. T.; Kulenovic, S. T. J. Org. Chem. 1980, 45, 891-894.

23. Yip, K.-T.; Yang, D. Org. Lett. 2011, 13, 2134-2137.

24. Ho, N. H.; Le Noble, W. J. J. Org. Chem. 1989, 54, 2018-2021.

25. Miura, K.; Wang, D.; Hosomi, A. J. Am. Chem. Soc. 2005, 127, 9366-9367.

26. Farndon, J. J.; Young, T. A.; Bower, J. F. J. Am. Chem. Soc. 2018, 140, 17846-17850.

27. Xu, S.; Jiang, J.; Ding, L.; Fu, Y.; Gu, Z. Org. Lett. 2018, 20, 325-328.

28. Zhao, Y.-J.; Li, B.; Tan, L.-J. S.; Shen, Z.-L.; Loh, T.-P. J. Am. Chem. Soc. 2010, 132, 10242-10244.

29. Stoermer, D.; Vitharana, D.; Hin, N.; Delahanty, G.; Duvall, B.; Ferraris, D. V.; Grella, B. S.; Hoover, R.; Rojas, C.; Shanholtz, M. K.; Smith, K. P.; Stathis, M.; Wu, Y.; Wozniak, K. M.; Slusher, B. S.; Tsukamoto, T. J. Med. Chem. 2012, 55, 5922-5932.

30. Günther, H. J.; Guntrum, E.; Jäger, V. Liebigs Ann. der Chemie 1984, 1984, 15-30.

31. Pan, Z.; Wang, S.; Brethorst, J. T.; Douglas, C. J. J. Am. Chem. Soc. 2018, 140, 3331-3338. 